RICARDO JOSÉ BARBOSA DA SILVA

\title{
HISTÓRIA INVISÍVEL: UMA ANÁLISE PSICOSSOCIAL DAS RAÍZES MÁGICO- RELIGIOSAS DO NACIONAL-SOCIALISMO
}

\author{
Tese apresentada ao Instituto de \\ Psicologia da Universidade de São Paulo, \\ como parte integrante dos requisitos para \\ obtenção do título de Doutor em \\ Psicologia.
}

São Paulo 


\section{HISTÓRIA INVISÍVEL: UMA ANÁLISE PSICOSSOCIAL DAS RAÍZES MÁGICO-RELIGIOSAS DO NACIONAL-SOCIALISMO}

Tese apresentada ao Instituto de Psicologia da Universidade de São Paulo, como parte integrante dos requisitos para obtenção do título de Doutor em Psicologia.

Área da concentração: Psicologia Social Orientador: Profa. Dra. Sueli Damergian

\section{São Paulo}




\title{
HISTÓRIA INVISÍVEL: UMA ANÁLISE PSICOSSOCIAL DAS RAÍZES MÁGICO-RELIGIOSAS DO NACIONAL-SOCIALISMO
}

\author{
RICARDO JOSÉ BARBOSA DA SILVA
}

\section{BANCA EXAMINADORA}

(Nome e Assinatura)

(Nome e Assinatura)

(Nome e Assinatura)

(Nome e Assinatura)

(Nome e Assinatura)

Tese defendida e aprovada em: 
A meus pais: Sofia, Adão e Conceição (in memorian) 


\section{AGRADECIMENTOS}

À Professora Sueli Damergian, minha orientadora, pela inspiração, pela confiança e pela amizade.

Aos professores Maria Inês Assumpção Fernandes e Eda Tassara, pelas sugestões apresentadas por ocasião do exame de qualificação.

A Daniela Onça, pela companhia, pelas sugestões e também pelo auxílio inestimável quanto a digitação deste trabalho.

A CAPES pelo auxílio financeiro.

E, finalmente, a todos os meus amigos, novos e velhos, por suportarem minha constante falta de tempo. 


\section{RESUMO}

Este trabalho consiste em uma análise psicossocial (de inspiração psicanalítica) das relações entre a ideologia nazista e o esoterismo alemão, sobretudo no que diz respeito ao mito racial ariano (sua "mitologia científica"). Ele pretende investigar, portanto, suas possíveis influências mágico-religiosas que remontam à mitologia germânica e, mais modernamente, às correntes esotéricas ocidentais e orientais.

Convém esclarecer que não pretendemos com isso explicar o nazismo através de seus possíveis vínculos com as sociedades secretas, reduzindo-o a um mero capítulo da história do esoterismo, mas apenas indicar uma nova direção de pesquisa em Psicologia Social para o tema e, conseqüentemente, para a análise dos movimentos neonazistas.

Palavras-chave: nazismo, esoterismo, ocultismo, irracionalidade. 


\begin{abstract}
This research consists in a psychosocial analysis (with a psyshoanalytical inspiration) of the relation between the nazi ideology and the german esoterism, specially its racial myth (its "scientific mythology"). It therefore aims to investigate its possible magical and religious influences that go back to german mythology and, more recently, to ocidental and oriental esoterical movements.

It is important to elucidate that we do not intend to explain the nazism through its possible links with secret societies, reducing it to a mere chapter of the history of esoterism, but only to point a new direction of research in social psychology to this subject and, consequently, to the study of neonazi movements.
\end{abstract}

Keywords: nazism, esoterism, occultism, irrationality. 


\section{SUMÁRIO}

INTRODUÇÃO

$\begin{array}{lr}\text { OBJETIVOS } & 8\end{array}$

METODOLOGIA 9

I. DETERMINISMO E ACASO NAS FORÇAS QUE MOVEM A HISTÓRIA 13

II. A MITOLOGIA GERMÂNICA 36

1. A cosmogonia dos antigos mitos germânicos 37

2. Os deuses e os mitos 39

III. RICHARD WAGNER E O MITO DA NOVA HUMANIDADE 41

1. Considerações biográficas 41

2. A tetralogia do anel 46

3. A reconstituição do paganismo germânico e o mito "vegetariano" da nova humanidade 62

IV. O NAZISMO ESOTÉRICO 72

1. O sanatório das coincidências exageradas 72

2. O realismo fantástico das influências nazistas $\quad 76$

V. AS VERDADEIRAS RAÍZES ESOTÉRICAS DO III REICH 90

1. O evolucionismo místico de H. P. Blavatsky 90

2. O armanismo: Guido von List e a Armanenschaft
(Comunidade Armanista)

3. O surgimento da ariosofia: a teozoologia de Lanz von Liebenfels, a revista Ostara e a Ordo Novi Templi (ONT) 103

4. O armanismo e a ariosofia na Alemanha: de Rudolf von Sebottendorff e a Thule Gesellschaft à Sociedade Edda 108

5. O misticismo de Heinrich Himmler e o mago Wiligut 128

6. O arianismo em Hitler e as influências de Lanz von
Liebenfels e da revista Ostara 
1. Do Romantismo ao Neopaganismo 145

2. Os mitos de origem

3. Os pressupostos psicossociais de uma filosofia de veterinários

4. Ciência, misticismo e modernidade

VII. UM DESAFIO PARA O SÉCULO XXI: O RESSURGIMENTO DAS IDÉIAS RACIAIS E O NEONAZISMO ESOTÉRICO 


\section{INTRODUÇÃO}

\begin{abstract}
"E vós aprendeis que é necessário ver e não olhar para o céu; é necessário agir e não falar. Esse monstro chegou quase a governar o mundo! Os povos o apagaram, mas não sejamos afoitos em cantar vitória: o ventre que o gerou ainda é fecundo"
\end{abstract}

(Bertolt Brecht)

Quando em setembro de 2004 o NPD (Nationaldemokratische Partei Deutschlands) conquistou 12 lugares no parlamento da Saxônia - obtendo algo em torno de 9,2\% dos votos -, toda a Europa reviveu a consternação de 2002, quando a extrema-direita francesa triunfou no primeiro turno da eleição presidencial com o candidato Jean-Marie Le Pen. Mas nada parecido, porém, com o índice ainda mais alto de simpatia para com a ideologia neonazista esboçado pela Suíça saxônica que ultrapassou os $15,1 \%$.

O argumento é o mesmo de sempre: jovens radicais desencantados com a globalização e os fluxos migratórios que aumentam ainda mais as taxas de desemprego, obrigando-os a migrarem pela Europa em busca de oportunidades profissionais. A xenofobia radicalizada vai buscar também no passado os clichês que permitem entender o martírio do povo alemão no presente, ao vincular a miséria de hoje às duras penalidades impostas pelos vencedores no pós-guerra.

O ressurgimento das políticas de identidade, ou melhor, sua reentrada em cena já que tais políticas jamais deixaram de existir - seria o bastante para responder a objeção de "por que ainda estudar o nazismo?" (como se as condições que possibilitaram aquela recaída em um estado de horror bárbaro já tivessem sido há muito tempo superadas), bem como lhe serviria de justificativa.

De qualquer forma, este trabalho não pretende discutir o já discutido retomando simplesmente as análises clássicas sobre o tema, se bem que, mesmo se o fizesse, integrando a tais análises os novos acontecimentos do cenário internacional, como a recente visibilidade dos partidos de extrema direita na Alemanha e na França, tanto quanto a tentativa desses partidos de colorirem com tons mais suaves os horrores dos regimes totalitários, como aponta bem a recente declaração do ex-candidato à 
presidência da França, Jean-Marie Le Pen, que afirmara que o regime nazista não fôra assim tão desumano como constantemente se apregoa, tal empreendimento já seria justificável ${ }^{1}$. Mas não é este o caso.

Ele pretende enveredar pela "história invisível" do nazismo, sob a perspectiva do esoterismo alemão a respeito do mito racial ariano, seu anti-semitismo, enfim, sobre a mitologia científica criada pela ideologia nazista. Não se trata, obviamente, de um trabalho esotérico, mas de um trabalho que eventualmente utilizar-se-á da esoterografia, que, como aponta o historiador do esoterismo Pierre Riffard ${ }^{2}$, teria como objetivo, entre outras coisas, o estabelecimento dos fatos, das influências e dos conteúdos sobre um tema particular do esoterismo.

O tema, que de certa forma reflete algumas preocupações já presentes em minha dissertação de mestrado - que trata dos Novos Movimentos Religiosos - surgiu da leitura do livro de Louis Pawels e Jacques Bergier, $O$ despertar dos mágicos, livro que é uma interessante mistura de literatura esotérica com história do esoterismo, exemplo claro da imbricação entre ciência e ocultismo. Nele, Pawels e Bergier alertam para as influências do ocultismo sobre a "ciência nórdica" pregada pelo III Reich, uma mistura do teosofismo com a revivescência de antigos mitos arianos, tudo isso enformado e catalizado pela influência de sociedades secretas como a Golden Dawn, o grupo Thule, a sociedade do Vril e a Rosa-Cruz moderna.

Os diversos trabalhos sobre o "nazismo mágico" tecem uma série de elucubrações sobre as possíveis raízes mágicas do nazismo e a origem do "mito ariano" de pureza racial, algumas bastante fantasiosas, outras, nem tanto. Verifiquemos as hipóteses mais comuns.

O pensamento hitleriano teria sofrido a influência da sociedade Thule, ramificada em pequenos grupos racistas e anti-semitas, criada pelo barão Rudolf von Sebottendorf, em 1912, e fortemente influenciada pelo esoterismo islâmico. Na tradição helênica, Thule seria o reino da misteriosa terra dos hiperbóreos, berço da raça original e fonte de grande poder, poder este que quem fosse capaz de dominá-lo, poderia "dominar o mundo". Pauwels e Bergier apontam que a Thule teria influenciado decisivamente o líder nazista Rudolf Hess, um de seus primeiros membros. O geógrafo e estrategista

\footnotetext{
${ }^{1}$ Lembremos também do recente incidente com um dos membros da família real britânica que foi flagrado por fotógrafos usando uma fantasia de nazista.

${ }^{2}$ Riffard, P. O Esoterismo, p. 50-51.
} 
Haushofer, segundo os autores, também teria sido um destacado membro de uma outra sociedade secreta, a sociedade do Vril, ligada à Thule.

A "loja luminosa" ou sociedade do Vril seria um grupo esotérico, vivo ainda hoje na Índia, seu país de origem, para onde Haushofer teria feito uma série de viagens estabelecendo contatos com os membros desta sociedade, adoradores do sol e cujos templos seriam adornados por cruzes gamadas. Essa idéia de uma teocracia secreta no oriente, originada das narrativas de Ferdynand Ossendowiski e René Guénon sobre o reino subterrâneo de Agarthi, onde habitava o Rei do Mundo, reino utópico cujos poderes sobrenaturais, quando liberados, poderiam transformar a superfície do planeta inteiro foram suplementadas pelo poder misterioso do Vril, que seria uma formidável reserva de energia da qual o homem só utilizaria uma ínfima parte, e cujos poderes incluiriam a telepatia e a telecinese, como aponta Mme. Blavatsky no seu Isis revelada.

O trabalho de Blavatsky (1831-1891), que é uma espécie de ensinamento secreto sobre a evolução do cosmos, ou seja, uma cosmogonia do novo sistema planetário, muito influenciará as futuras cosmologias esotéricas modernas (como aquela que será desenvolvida por Horbiger e aceita por Hitler, na Alemanha nazista). Segundo ela, e de acordo com a sua obsessão com o número 7 (sete seriam os ciclos de vida na Terra, as raças humanas, os princípios vitais do ser humano, etc.), estaríamos vivendo a quarta manifestação de vida na Terra, após já termos evoluído através do reino mineral, vegetal e animal.

O historiador Goodrick-Clarke, pioneiro no estudo histórico dos "mistérios nazistas", mesmo não aceitando a ligação frágil que os esoteristas tecem entre Haushofer e as sociedades secretas, e critique a literatura sensacionalista sobre o tema, que proliferou na Alemanha inspirada nesses primeiros mitólogos, ele supõe que estes teriam acertado ao concentrarem-se em Himmler, que realmente estivera absorvido em tradições esotéricas, na Atlântida, e nas origens mitológicas da raça ariana, o que motivara a expedição da SS para o Tibete, sob a supervisão da Ahnenerbe ("Herança Ancestral"), instituição interior à SS e que motivava pesquisas em biologia, hereditariedade e genética ${ }^{3}$.

O fato talvez explique o porquê de quando os russos tomaram Berlim, em 1945, terem encontrado os cadáveres de muitos tibetanos trajando o uniforme alemão, sendo que não havia qualquer relação política ou comercial entre o Reich e o Tibete. E

\footnotetext{
${ }^{3}$ Goodrick-Clarke. Sol Negro: cultos arianos, nazismo esotérico e políticas de identidade, p. 159-160.
} 
Himmler acreditava, diga-se de passagem, na teoria do gelo mundial (ou teoria do Gelo Cósmico) de Horbiger, pseudocientista nazista cujas idéias Hitler admirava, por motivos muito compreensíveis: Horbiger acreditava que dilúvios primordiais haviam submergido a Atlântida e que os ancestrais dos alemães (descidos dos céus e estabelecidos em Atlântida) haviam se fortalecido graças ao gelo e ao frio.

Outro fato muitíssimo curioso e que não passou despercebido aos historiadores era a obsessão de Hitler com relação à invasão de Stalingrado. Sabemos que Halford J. Mackinder, o maior teórico da geopolítica clássica (cujas idéias seriam aplicadas por Haushofer, estrategista de Hitler) constrói toda uma teoria que tem como pivot a geografia, mais especificamente a geopolítica. Sua principal contribuição foi a criação da idéia da heartland, principal região geoestratégica do planeta que corresponde aproximadamente à Europa Oriental (o que inclui o oeste da Rússia).

A importância dessa região derivaria da presença de extensas planícies que estender-se-iam da Alemanha até as estepes russas, e que favoreceria a mobilidade e o crescimento das populações. Friedrich Ratzel, antecedendo Mackinder, desenvolve teorias sobre o crescimento dos Estados e antecipa um conceito de grande importância para o futuro expansionismo alemão: a idéia de "espaço vital" (por mais que tal termo não surja aí) definido como o espaço necessário para o bom crescimento e desenvolvimento de uma população. Suas leis de expansão espacial dos Estados influenciarão profundamente o pensamento geopolítico alemão, atingindo seu clímax com a agressividade do III Reich de Hitler, período este em que, em torno do Instituto de Geopolítica de Munique, e sob a liderança de Haushofer, será finalmente cunhada a expressão Lebensraum (Espaço Vital), o território ideal de uma sociedade. O termo surgirá exatamente com essa conotação no Mein Kampf de Hitler.

Pois bem, o general-geógrafo alemão Haushofer opunha-se terminantemente a uma guerra com a Rússia, por ver nela uma aliada geopolítica natural, e também por perceber que a invasão de um país de dimensões continentais como aquele seria impraticável, coisa que a história já havia mesmo se encarregado de comprovar quando da tentativa fracassada de Napoleão. Mesmo assim, por conta da obsessão de Hitler por Stalingrado, sua relação com Haushofer sofre um duro golpe com a invasão da Rússia, rompendo-se assim o pacto Ribbentrop-Molotov, de não agressão.

Martin Kitchen também não deixa de apontar a irracionalidade de Hitler em não se deixar guiar por considerações geopolíticas razoáveis. Os estrategistas de Hitler, em frente ao inevitável, sugeriram a tomada de Moscou. Hitler, irredutível, por motivos 
racionalmente inexplicáveis, insistia em tomar Stalingrado. O resultado já era de se esperar: Stalingrado não se entrega e a campanha nazista na Rússia se apresenta como o começo do fim do expansionismo alemão. Os historiadores resolvem o mistério com base na rivalidade secular entre eslavos e germânicos ${ }^{4}$.

Um outro exemplo do interesse do nazismo pela simbologia ocultista foi a escolha da cruz gamada (considerada um símbolo mágico), por mais que Hitler justificasse tal escolha de uma forma um pouco menos "mística": para ele, ela representava "a missão de luta pelo triunfo do homem ariano ao mesmo tempo que a idéia do trabalho criador, já que ela sempre foi e será anti-semítica". ${ }^{5}$ Quanto a isso, convém esclarecer que se trata de um erro freqüente perguntarmo-nos como a suástica (do sânscrito $s u$, bem, e ast, ser), um signo de bom agouro na religiosidade indiana, de sucesso e fortuna, ter-se-ia convertido em seu oposto quando incorporada aos símbolos nazistas. $\mathrm{Na}$ verdade a cruz gamada está presente em diversas culturas (girando para a esquerda ou para a direita).

Poliakov, em seu trabalho "O mito ariano", afirma que

“À primeira vista parece desconcertante atribuir aos mitos da Cidade Eterna ou àqueles da floresta germânica alguma ação eficaz sobre a ascensão de Mussolini ou sobre aquela do Führer. Uma tal proposição, que parece provocar um curto-circuito, por assim dizer, de quinze séculos de história, é contrária às concepções e aos métodos históricos usuais. Contudo, a verdade é que os fascistas se valiam dos primeiros e os nazistas dos segundos" 6

Entretanto, Poliakov se detém, sobretudo, nas raízes pré-científicas da antropologia racista alemã e no surgimento do mito ariano, rastreando suas diversas origens, explorando as influências provenientes do oriente, mas sem vinculá-las diretamente ao surgimento de uma religião germânica de inspiração mística. Mesmo assim ele não deixa de notar que no século XVIII os antepassados bíblicos começaram a ser contestados pelos iluministas e pela razão, momento este em que a mitologia bíblica e romana é substituída, nos poemas de Friedrich G. Klopstock, pela mitologia germânica, bem mais sanguinária. Mas para Poliakov, as obras de Herder teriam deixado ainda mais marcas na literatura alemã que as de Klopstock, escritor que,

\footnotetext{
${ }^{4}$ Kitchen, M. Um mundo em chamas: uma breve história da Segunda Guerra Mundial na Europa e na Ásia, 1939-1945.

${ }^{5}$ Hitler, A. Minha Luta, p. 371.

${ }^{6}$ Poliakov, L. O mito Ariano, p. xix
} 
interessado em todas as mitologias (bíblicas, indianas, nórdicas) teria sido um dos principais precursores do mito ariano.

E dentre tais precursores está Richard Wagner (1813-1883). Francamente antisemita, Wagner representa na música uma verdadeira fusão entre os elementos mitológicos da cultura germânica e o nacionalismo alemão. A obsessão reformista de Wagner quanto à ópera tinha como foco a "regeneração social", que apontava para uma Alemanha degenerada pela mistura racial com os judeus (o que incluía os músicos). Daí Wagner buscar a inspiração para suas composições nos Eddas, coleção de antigos poemas mitológicos compostos no século XI, bem como em outras fontes medievais (Völsunga Saga e a Edda em prosa de Snorri Sturluson). É daí que surgem obras românticas como Parsifal, Lohengrim, Tristão e Isolda (que Hitler afirmara ter assistido umas 30 ou 40 vezes) e a tetralogia denominada $O$ Anel dos Nibelungos (O ouro do Reno, A Valkíria, Siegfried, Crepúsculo dos Deuses), onde surgem personagens como Wotan, Fricka, Freia e Erda (todas divindades mitológicas), além de ninfas, gigantes e anões.

Tal como Poliakov, o germanista Norbert Elias também aponta para o surgimento na Alemanha de uma religião social capaz de justificar a ideologia do III Reich, mas sem qualquer referência a uma verdadeira religiosidade mística de caráter pré-cristão (pagão), genuinamente germânica:

“ (...) aos outros instrumentos de domínio, adicionaram mais um que é característico das sociedades de massa: governar e disciplinar por meio de uma crença social. Eles não estavam sós a proceder desse modo. $\mathrm{O}$ uso de uma nova religião social como instrumento de construção imperial, como um meio para manter e estabilizar o domínio de uma minoria sobre uma maioria mantida em sujeição, era um desenvolvimento geral nesses tempos",

Convém notar, também, que por mais que Goodrick-Clarke critique o sensacionalismo em torno dos mistérios nazistas, que vê no holocausto a sombra de uma guerra dualística no paraíso entre o Bem e o Mal, sobretudo na literatura popular da década de 1960, ele reconhece plenamente que, no caso do neonazismo, a influência dessa literatura e, portanto, dos cultos mágicos a que elas fazem alusão, é clara e inequívoca. Muitas são as seitas neonazistas de inspiração esotérica e luciferinas que foram buscar nessa literatura o fundamento para suas crenças racistas. O que ele discute

\footnotetext{
${ }^{7}$ Elias, N. Os Alemães, p. 332.
} 
é se tais influências foram decisivas nos assuntos internos do III Reich, criticando a redução do nazismo às sociedades secretas, cuidado este que julgamos mesmo necessário.

T.W. Adorno ${ }^{8}$ por sua vez, mesmo acreditando que o anti-semitismo burguês teria um fundamento especificamente econômico, não deixa de analisar o tema em seu conteúdo religioso. O mesmo vemos em Wilhelm Reich ${ }^{9}$, outro herdeiro do marxismo e da psicanálise, que não esquece de estabelecer a relação entre a mitologia racial ariana, o suposto envenenamento do sangue e o misticismo implicado nessa relação. Ademais, é impossível não concordarmos com Ribeiro Júnior quando este afirma, mas sem se aprofundar no tema, que:

“A verdade é que o nazismo é muito mais que um simples movimento político. Há qualquer coisa nele que escapa à visão racionalista, onde só se vê a luta entre a concepção liberal-democrática e a concepção autoritária nazi-fascista das sociedades. $\mathrm{O}$ mito da pureza da raça ariana (Deutsches Ahnenerbe, herança ancestral alemã), cerimônias rituais inspiradas no paganismo germânico, e a recuperação do simbolismo das religiões orientais, fazem parte de um fundo muito mais esotérico do que político"

\footnotetext{
${ }^{8}$ Adorno, T; Horkheimer, M. Dialética do Esclarecimento.

${ }^{9}$ Reich, W. Psicologia da Massas do Fascismo.

${ }^{10}$ Ribeiro Jr. Que é nazismo ? p. 77.
} 


\section{OBJETIVOS}

Este trabalho tem como objetivo examinar as possíveis influências de algumas idéias de caráter místico sobre a ideologia nazista e suas idéias raciais, investigando o impacto de algumas idéias mágicas e esotéricas como a batalha entre o fogo e o gelo eterno de Horbiger (pseudocientista nazista), Heinrich Himmler e a criação da SS, inspirada na Ordem dos Jesuítas e na companhia de Jesus, os elos entre o nazismo e o meio ocultista com suas fantasias conspiratórias, seus mitos acerca de civilizações perdidas, etc.

Pretendemos com ele deslocar o foco da discussão sobre o nazismo como mero movimento político, fruto da reação dos estratos mais conservadores da Alemanha à expansão do comunismo que culminou no embate entre a concepção liberal-democrática e o autoritarismo fascista, tentando identificar nele algo que acabou escapando às análises clássicas sobre o tema (porém, como já dissemos antes, sem reduzi-lo meramente a um capítulo da história do esoterismo), recuperando assim uma certa "história invisível" a partir da sobrevivência na cultura alemã de idéias raciais inspiradas em elementos de sua própria mitologia religiosa. 


\section{METODOLOGIA}

Concordamos com Max Weber em supor a racionalidade como uma equação dinâmica entre meios e fins, que faz com que toda ação humana seja motivada por determinadas concepções afetivas do desejável que se impõem aos homens como metas a serem atingidas. Daí as ações humanas variarem de acordo com determinados tipos de orientação para as ações baseadas em hábitos, nos afetos dos agentes, ou na crença em determinado valor ético ou religioso.

O "tipo puro" ou "tipo ideal” é uma construção conceitual central na discussão metodológica em Weber, representando um tipo extremo. Essas construções ideais típicas correspondem a certos elementos da realidade ordenados sob a forma de uma máxima racionalidade, como o "feudalismo", o "homem econômico" ou as leis estabelecidas pela teoria pura da economia. Nas palavras do próprio Weber, essas construções ideais típicas "expõem como se desenrolaria uma ação humana de determinado caráter se estivesse orientada pelo fim de maneira estritamente racional sem perturbações por erros e afetos"1. Uma ação orientada pelo fim de maneira estritamente racional (e poderíamos dizer "típica") serve à sociologia como "tipo ideal". A ação real raramente coincidirá com o "tipo ideal", mas permite "compreender a ação real, influenciada por irracionalidades de toda espécie (afetos, erros) como "desvio do desenrolar a ser esperado no caso de um comportamento puramente racional".

Max Weber entende essa conveniência metodológica como "racionalista" em certa medida, mas defende a sociologia compreensiva do preconceito racionalista argumentando tratar-se apenas de um recurso metodológico: "no entanto, é claro que esse procedimento não deve ser interpretado como preconceito racionalista da sociologia, mas apenas como recurso metodológico. Não se pode, portanto, imputar-lhe a crença em uma predominância afetiva do racional sobre a vida"2.

Por mais que toda ciência e toda interpretação pretendam alcançar certeza, lembra-nos, "nenhuma interpretação, por mais evidente que seja quanto ao sentido", alerta-nos Weber, "pode pretender como tal e em virtude desse caráter de evidência, ser também a interpretação causal válida. Em si, nada mais é do que uma hipótese causal de evidência particular"’3. E aqui, dando seguimento à explicação daquelas ações com

\footnotetext{
${ }^{1}$ Weber, M. Economia e sociedade, vol. I, p. 5

${ }^{2}$ Idem, ibidem, p. 5.

${ }^{3}$ Idem, ibidem, p. 7.
} 
menor grau de evidência (mas suficientes para as suas e para as nossas exigências de explicação), ele fornece a sua melhor defesa contra as acusações de preconceito racionalista à "sociologia compreensiva", e que nos interessa sobremaneira por conta de futuras reflexões psicanalíticas que terão lugar em nossa tese:

“a) Em muitos casos, supostos 'motivos' e 'repressões' (isto é, desde logo, motivos não reconhecidos) ocultam ao próprio agente o nexo real da orientação de sua ação, de modo que também seus próprios testemunhos subjetivamente sinceros têm valor apenas relativo. Neste caso, cabe à Sociologia a tarefa de averiguar essa conexão e fixá-la pela interpretação, ainda que não tenha sido elevada à consciência, ou, o que se aplica à maioria dos casos, não o tenha sido plenamente, como conexão "visada" concretamente: um caso-limite da interpretação do sentido. b) manifestações externas da ação que consideramos "iguais" ou "parecidas" podem basear-se em conexões de sentido bem diversas para o respectivo agente ou agentes; e "compreendemos" também ações extremamente divergentes, ou até opostas quanto ao sentido, em face de situações que consideramos "idênticas" entre si (exemplos na obra de Simmel, Die Probleme der Geschichtsphilosophie). c) Diante das situações dadas, os agentes humanos ativos estão freqüentemente expostos a impulsos contrários que se antagonizam, todos eles compreensíveis para nós."4.

É exatamente o afastamento entre o "tipo ideal" e aquilo que verificamos na realidade, o que mais nos interessa em Weber, porque esse afastamento aponta para uma série de fatores intervenientes que surgem como "perturbações" por "erros ou afetos" como o autor assinala.

Acreditamos também, com Marx, no caráter material da existência humana, isto é, em seu caráter concreto e histórico, mas não pensamos que as condições materiais da existência (sobredeterminações econômicas, principalmente) sejam o único motor das transformações sociais e históricas. Nossa oscilação entre Marx e Weber não é, porém, fortuita ou fruto de ecletismo teórico. Não existe, como se pensa, verdadeira oposição entre Marx e Weber, apesar de suas discordâncias. Aquilo que Weber critica em Marx não é sua teoria da sobredeterminação econômica da história, e sim sua insistência nessa monocausalidade que o faz cego para determinações outras que Weber julga tão importantes quanto aquelas provenientes da economia. A obra de Weber não tenta, portanto, rejeitar as concepções de Marx, mas completá-las, como atesta sua Ética protestante e o espírito do capitalismo (e o resto de sua sociologia da religião), com

\footnotetext{
${ }^{4}$ Idem, ibidem, p. 7.
} 
aquelas determinações provenientes de concepções éticas e religiosas. Surgem na obra de Weber, portanto, a valorização de outras esferas distintas da esfera econômica, bem como uma preocupação com a importância do "líder carismático" capaz, também, de fazer soprar os ventos da história.

Tais considerações metodológicas devem-se à implicação, neste estudo, de uma determinada concepção de história, problema acerca do qual não pretendemos nos esquivar. Ao tomarmos em consideração o misticismo do III Reich, bem como a personalidade mística de Hitler, não pretendemos com isso, como bem salientou Tolstoi, deduzir os acontecimentos históricos exclusivamente da personalidade de Napoleões, Alexandres ou outros. Mas, concordamos com Plekhanov quando diz que determinados indivíduos (em virtude de traços particulares) podem influenciar no destino de uma sociedade, apesar de sua conclusao de que

"a possibilidade de exercer tal influência, e a sua extensão, são determinadas pela forma de organização da sociedade, pela correlação de forças dentro dela. $\mathrm{O}$ caráter de um indivíduo é um 'fator' no desenvolvimento social apenas onde, quando e na medida em que o permitam as relações sociais",

O historiador Sidney Hook rejeita essa tentativa de síntese de Plekhanov, incapaz de escapar do determinismo social ao afirmar a importância dos grandes líderes para então retornar à supervalorização das condições objetivas em detrimento de qualquer outra influência. Para ele, a dificuldade consiste em descobrir quando o herói seria um "acidente" histórico e quando ele seria um verdadeiro agente de mudança, nunca perdendo de vista o fato de que, na história, tanto quanto na natureza, podemos notar que determinados eventos estariam mais significativamente ligados entre si do que outros. Ora, pretendemos aqui discutir o papel de outros determinantes históricos que podem ter auxiliado no sucesso do nacional-socialismo e, sobretudo, na formação de sua ideologia racista. Sendo assim, para nós interessa saber quando determinadas idéias ou concepções religiosas poderiam ser consideradas "acidentes históricos" e quando, efetivamente, poderíamos tomá-las como agentes condicionantes de determinado movimento histórico.

A psicanálise por sua vez, enquanto doutrina do funcionamento mental irracional, parece dispor das ferramentas necessárias para esclarecer parte dos motivos

\footnotetext{
${ }^{5}$ Plekhanov, O Papel do Indivíduo na História. In: Gardner, P. Teorias da História, p. 191.
} 
inconscientes a que Weber se refere, vindo assim em auxílio das análises históricas e sociológicas sobre o tema. Assim, de modalidade clínica, e como auxílio do freudomarxismo (que tem hoje como herdeira a Teoria Crítica daquilo que conhecemos como a "Escola de Frankfurt"), que tem como objetivo buscar no sujeito os ecos da patologia do social, pretendemos utilizar a psicanálise como Ideologiekritik, por conta de seu caráter desmistificador. Afinal, aquilo que a Psicanálise faz, sua principal contribuição à crítica da cultura, é a de não compactuar com o senso comum, mantendo a distinção entre essência e aparência. E sua afirmação do caráter sexual de fenômenos como o sadismo, que culminaram no prazer derivado da violência da política de extermínio dos totalitarismos (tanto de direita quanto de esquerda), é muito mais verdadeira que a explicação superficial das psicologias da "consciência" que apontam para uma "vontade de poder" associada ao medo ou à vingança. 


\section{CAPÍTULO I: DETERMINISMO E ACASO NAS FORÇAS QUE MOVEM A HISTÓRIA.}

\author{
"a história universal, a história que o homem \\ realizou neste mundo, é fundamentalmente a história \\ dos homens que atuaram à superfície da terra." \\ (Thomas Carlyle)

\begin{abstract}
"O modo de produção da vida material determina o caráter geral dos processos de vida social, política e espiritual. Não é a consciência dos homens que determina a sua existência, mas, pelo contrário, é a sua existência social que determina a sua consciência".
\end{abstract}

(Karl Marx)

Apesar de Kant nunca ter dedicado à filosofia da história o mesmo tempo que dedicou à filosofia da ciência ou à Ética, há um ensaio seu intitulado "A idéia de uma história universal de um ponto de vista cosmopolita" que será de grande importância para o desenvolvimento futuro de algumas teorias da história. Mas aquilo que mais nos interessa neste ensaio é que ele representa uma reação às correntes providencialistas acerca da interpretação da história. Reação essa que, por não conseguir se livrar totalmente das implicações religiosas das filosofias da história em Santo Agostinho, Bossuet ou Maritain, será agrupada (ao lado de Vico e Herder) sob a denominação de "corrente semiprovidencialista". A distinção entre esta e aquela jaz na importância atribuída pelos seus integrantes ao papel da providência (divina) na condução do processo histórico.

Ao longo de todo o ensaio, Kant precisa confrontar o problema que até hoje permanece central na filosofia da história: a aparente irracionalidade do processo histórico. Problema esse que ele pretende solucionar apelando a um suposto "princípio teleológico" capaz de justificar os males da história.

Ele afirma, já no início de seu ensaio, que, a despeito da posição metafísica em questão, é inequívoco que os atos humanos (como qualquer fenômeno da natureza) seriam regidos por "leis naturais de caráter universal", e que a História, por ocupar-se da narração das manifestações humanas, estaria apta a descobrir um curso regular nessas 
manifestações. Aquilo que pareceria, portanto, irracional e irregular em indivíduos isolados, poderia ser entendido no conjunto da espécie como um desenvolvimento lento, porém contínuo (orientação "progressista"). Notemos que tal esperança surge do horror que a possibilidade de não existir um "sentido" na história causava nos filósofos de inspiração iluminista, onde o ideal de razão não permitiria o caos (fruto do acaso) que parece reinar na história da humanidade.

\begin{abstract}
"Não podemos deixar de sentir uma certa repugnância, quando vemos os seus atos [dos homens] representados no palco do mundo; e embora apareçam aqui e ali uns vislumbres de sensatez em casos isolados, tudo surge finalmente, na generalidade, como que entretecido de loucura, de vaidade pueril, muitas vezes de infantil maldade e sede de destruição, acabando nós por não saber que conceito fazer da nossa espécie, tão orgulhosa da sua superioridade. Perante isso, o filósofo, na impossibilidade de pressupor um específico propósito racional nos homens ou nos seus atos em geral, não tem outra solução senão tentar descobrir um desígnio da natureza nesta mancha absurda das coisas humanas, a partir do qual seja possível uma história que obedeça a um determinado plano da natureza, a propósito de criaturas que agem sem um plano próprio"
\end{abstract}

É na tentativa de evitar a idéia de uma natureza que agisse sem finalidade que Kant apela para uma "teoria natural teleológica", que prega que a espécie humana, dotada como é de razão, estaria fadada a atingir o pleno desenvolvimento de suas disposições. E o meio através do qual a natureza conduziria a evolução sociopolítica da humanidade seria o antagonismo social, essa propensão humana para se associar, sempre ligada a uma resistência (daí o antagonismo) que ameaça constantemente a sociedade da desagregação. Em outros termos, a consciência social, ao oferecer resistência aos desejos humanos, desperta neste a força necessária capaz de neutralizar sua propensão à preguiça, conduzindo-o através da ambição e do instinto de domínio e cobiça "a conquistar um lugar entre os seus semelhantes, que ele não suporta, mas sem os quais ao mesmo tempo não pode passar"2.

É assim que, para Kant, dá-se a passagem do barbarismo à cultura e, conseqüentemente, à moralidade: a partir da sociabilidade insociável do homem. A partir disso, o homem é conduzido à necessidade de estabelecer uma sociedade civil,

\footnotetext{
${ }^{1}$ Kant, Idéia de uma história universal de um ponto de vista cosmopolita, in: Gardner, P. Teorias da história, p. 29.

${ }^{2}$ Idem, ibidem, p. 32.
} 
submetida a leis externas. Em resumo, a tendência humana a tomar para si o melhor negando-o ao seu semelhante é o motor que conduz o homem à cultura: "toda a cultura e a arte que adornam a humanidade, assim como a mais bela ordem social, são frutos da insociabilidade, que por si própria é obrigada a disciplinar-se e a desenvolver assim plenamente, por uma arte compulsiva, os germes da natureza"3.

Eis aí o problema da concepção de natureza em Kant: trata-se de uma força capaz de conduzir a espécie humana através de um curso regular da animalidade à humanidade, ou seja, a natureza tal como este a concebe possui uma "finalidade". A sugestão bastante explícita de Kant é a de que existe um certo "plano oculto" da natureza dirigindo a história humana rumo à "perfeita união política da espécie humana". Uma tal justificação da natureza implica uma determinada idéia de "providência", mesmo que não necessariamente (ou explicitamente) divina. Com isso ele consegue neutralizar o "acaso".

A crítica a essa concepção de uma providência capaz de organizar as coisas veio de um aluno de Kant cujo nome está intimamente relacionado ao movimento romântico: Johann Gottfried Herder. Não só aluno de Kant, mas também amigo de Goethe, Herder defende, contra seu antigo professor em Königsberg, a seguinte lei fundamental da história:

\footnotetext{
"que por toda a parte, na Terra, acontece tudo quanto nela pode acontecer, em parte de acordo com a situação e as necessidades do lugar, em parte de acordo com as circunstâncias e as condições da época, em parte de acordo com o caráter nato ou adquirido dos povos"
}

Para Herder, a característica mais marcante da história seria a variedade, a individualidade das nações a partir das diferentes raças, das diferentes formas de educação, climas e modos de pensar de cada um dos povos. Sendo assim, seria um erro supor que a história fosse a manifestação da "natureza humana". Os fins da história não estariam sendo tecidos através de "desígnios ocultos" e nem estariam sujeitos à "influência mágica de demônios invisíveis": "o destino revela os seus desígnios através daquilo que acontece e de como acontece; por isso o observador da história deduz esses

\footnotetext{
${ }^{3}$ Idem, ibidem, p. 33.

${ }^{4}$ Herder, Idéias para a filosofia da história da humanidade, in: Gardner, P. Teorias da história, p. 43.
} 
desígnios apenas a partir daquilo que é e do que se lhe revela dentro de todo o seu âmbito", .

Tudo parece ir muito bem até aqui, mas as diferenças entre Herder e Kant não são assim tão inequívocas. O pensamento daquele parece ser tão finalista quanto o deste. Para Herder, "o humanismo é a finalidade da natureza humana". Nada muito diferente de Kant, sobretudo quando este diz que

\footnotetext{
"se existe um Deus na natureza, existe igualmente na história. Porque também o homem faz parte da criação, nos seus mais violentos excessos e paixões, obedece necessariamente a leis que não são menos belas e excelentes do que aquelas por que se regem todos os corpos celestiais e terrestres"
}

A diferença parece estar na ênfase. Kant apela para uma explicação calcada na natureza humana, enquanto Herder enfatiza o ambiente, as peculiaridades próprias a cada povo e suas organizações políticas. Tal ênfase recai, portanto, em uma espécie de "natureza dos povos", em oposição à "natureza humana" da concepção kantiana.

De qualquer forma, tanto em Kant quanto em Herder fica escamoteado o problema do indivíduo na história. Em Kant temos a abstração de uma "natureza humana" que funciona como uma "força oculta", fazendo girar a roda da história rumo a um progresso na moralidade sem grandes considerações acerca da liberdade no interior desse progresso inevitável. Já em Herder, o gênio dos povos - sua capacidade intrínseca - bem como o tempo e o lugar parecem obscurecer a liberdade individual. Seu providencialismo deve-se à constatação de que a razão, conferida por Deus ao homem, é o móvel do progresso humano. Mas mesmo assim podemos ver, tanto em Kant quanto em Herder, o tal progresso como um triunfo da vontade.

Manter na interpretação do devir histórico um equilíbrio perfeito entre o individual e o coletivo nunca foi tarefa das mais simples. A tentativa de solucionar o desequilíbrio presente em Herder e Kant será tentada por Hegel, primeiro filósofo a ocupar-se sistematicamente com a história e, mais exatamente, a pretender fazer filosofia da história.

Aproximando-se de Herder, Hegel encontrará na Razão (também Idéia ou Espírito) a realidade absoluta de todo o existente, realidade esta da qual emanará tanto a natureza quanto a história. Em outros termos, Hegel entende que a essência do espírito é

\footnotetext{
${ }^{5}$ Idem, ibidem, p. 48.

${ }^{6}$ Idem, ibidem, p. 53.
} 
a liberdade, e que esta, ao se desenvolver no mundo, utilizando para isso de meios fenomênicos, apareceria à nossa visão através da História.

Hegel percebe, como Kant, que as necessidades e paixões dos homens são móveis da ação, mas não conclui daí um conluio de "forças ocultas" ditando os rumos da história. Entretanto, afirma que a acumulação de vontades e interesses constituiria os instrumentos e os meios que o "Espírito cósmico" utilizaria para atingir o seu objetivo. Ele entende o problema de se afirmar que os indivíduos e os povos, ao procurarem satisfazer seus próprios fins, estariam - inconscientemente - satisfazendo um fim mais elevado, mas tenta solucionar essa questão com a convicção de que a Razão, ao governar o mundo, governaria também a sua história.

Neste ponto, Hegel discute o papel de determinados tipos de indivíduos que ele denomina "indivíduos histórico-cósmicos”, utilizando César como exemplo. O argumento de Hegel é o de que César, ao conduzir a política de Roma a uma autocracia, mesmo movido por interesses pessoais, seguia a vontade do "Espírito cósmico":

\begin{abstract}
"Não foi, pois, apenas o seu [de César] lucro particular, mas um impulso inconsciente que motivou a realização daquilo para que a época estava pronta. Assim são todas as grandes individualidades históricas - cujos fins particulares envolvem os vastos caminhos que constituem a vontade do Espírito cósmico. Pode-se chamar-lhes Heróis, na medida em que os seus fins e a sua vocação não os derivam do curso regular e calmo das coisas sancionadas pela ordem em vigor, mas sim de uma origem invisível - que não chegou a aflorar a existência presente e fenomênica - daquele Espírito interior sempre oculto sob a superfície, que, embatendo no mundo exterior como numa concha, o desfaz em pedaços por não ser o conteúdo adequado a essa concha. São, pois, homens que parecem arrancar de si mesmos o impulso da vida, e cujos feitos produziram uma nova ordem de coisas e um complexo de relações históricas que parecem ser apenas o seu próprio interesse e obra sua",
\end{abstract}

Temos aqui a origem daquela que viria a ser a concepção mais influente do "determinismo social" do século XIX. Hegel tinha como alvo os racionalistas do século XVIII que tendiam a explicar a história a partir da "fortuna" ou da "psicologia pessoal"8. Convém notar que, enquanto isso, Carlyle desenvolvia - sob a influência de Goethe e do Romantismo alemão - sua interpretação individualista (ou heróica) da história, que chegará a influenciar a concepção de Nietzsche acerca do "Super-homem".

\footnotetext{
${ }^{7}$ Hegel, G. W. História filosófica, in: Gardner, P. Teorias da história, p. 76.

${ }^{8}$ Hook, S. O herói na história, p. 56.
} 
Hegel supõe que determinados indivíduos conseguem apreender a realidade de uma época com mais intensidade que outros e, mesmo agindo de forma inconsciente, realizam aquilo que já estava maduro, figurando assim como agentes do espírito cósmico. Tais figuras histórico-mundiais raramente encontraram a felicidade neste mundo: morreram cedo (Alexandre), foram assassinados (César) ou exilados (Napoleão). Estes homens históricos "são grandes homens porque souberam querer e realizaram algo de grande; não uma simples fantasia ou mera intenção, mas aquilo que era adequado e de acordo com as necessidades da época"9.

É vinculando a ação desses grandes homens às necessidades de determinada época que Hegel supõe ter conseguido excluir o "ponto de vista psicológico" do devir histórico. Ele rejeita a idéia de que a história se mova somente a partir de alguma paixão (seja ela mesquinha ou grandiosa) dos homens. Não teria sido, afirma ele, por conta de algum desejo mórbido de fama e conquista ou qualquer obsessão semelhante que Alexandre da Macedônia teria subjugado parcialmente a Grécia e depois a Ásia. Mas a explicação que Hegel fornece para o fato de que as paixões que habitam o homem moverem-no não de forma casual para qualquer direção, mas apenas para a direção ditada pelo Espírito da época é muito próxima à solução kantiana. A “força oculta” aqui implicada toma o nome de "ardil da razão", e representa a forma pela qual a razão dispõe as paixões em seu benefício. Assim é que o particular - demasiado mesquinho rende-se à força do geral. Trabalho feito, realizado o sentido da história através do grande homem (que é grande, de certa forma, por ter consciência disso), ele pode ser descartado pela história. Os heróis morrem cedo...

Em resumo, para Hegel,

“O papel desempenhado em história por pessoas particulares só parcialmente se explica mediante a consideração de seus interesses imediatos e coerentes, deve-se fazer referência às poderosas forças históricas de que elas são tanto os instrumentos como (até certo ponto) os intérpretes. As ações dos indivíduos devem assim ser julgadas dentro do contexto histórico que 'exige', ou torna necessária a sua realização",10.

O que existe de mais terrível na teoria da historia de Hegel - e que reflete, obviamente, os pressupostos de sua filosofia idealista - é a idéia de que as coisas são como são porque são exatamente aquilo que deveriam ser, e isso em nome da Razão, do

\footnotetext{
${ }^{9}$ Idem, ibidem, p. 77.

${ }^{10}$ Hegel, G.W. História filosófica, in: Gardner, P. Teorias da história, p. 73.
} 
Bem e da Verdade. "O mundo real é como deveria ser"11, e o verdadeiro bem, encarnação da "divina razão universal", é um princípio vital capaz de se realizar. Este "bem", que equivale à "Razão" é, na verdade, Deus. E Deus dirige o mundo, e seu plano concretizado apresenta-se para nós como a "História do mundo". Diante dessa idéia divina desaparece o acaso nos acontecimentos do mundo. A filosofia estaria aí para justificar a "tão desprezada Realidade das coisas".

De qualquer forma, e apesar dos excessos quase "místicos" do determinismo social hegeliano, ele foi muito útil em reação ao misticismo individualista (heróico), ainda mais pernicioso, que vinha se desenvolvendo a partir do trabalho de Carlyle (1795-1881) sobre o papel do grande homem na história.

Como já apontamos antes, sob a influência das idéias de Goethe e do romantismo alemão, Carlyle afirma, de forma taxativa, que

\footnotetext{
"a história universal, a história que o homem realizou neste mundo, é fundamentalmente a história dos homens que atuaram à superfície da terra. Foram condutores de homens, os homens superiores; modeladores, forjadores e, num sentido amplo, criadores, de quanto as multidões se propuseram fazer ou atingir. Todas as coisas que vemos terem sido realizadas no mundo são propriamente o resultado material, a elevação prática, a incorporação, dos pensamentos que surgiram nos homens superiores, enviados ao mundo; pode dizer-se com justiça que a alma de toda a história mundial é a história dessas almas." 12
}

Leitor da biografia de grandes líderes e entusiasta da mitologia germânica, Carlyle parece ter prestado mesmo um desserviço para os defensores da importância dos indivíduos na história, como é o caso de Sidney Hook, que argumenta, com certo desprezo, que o livro de Carlyle

\begin{abstract}
"não foi tomado pelo que é - um folheto para os tempos, cheios de fervor moral explosivo e sufocante, iluminado aqui e ali por um lampejo de clarividência, mas contraditório, exagerado e impressionista. Em vez disso foi considerado como uma defesa seriamente argumentada de que todos os fatores na História, exceto os grandes homens, eram inconseqüentes. Literalmente analisadas, as noções de causalidade histórica de Carlyle são visivelmente falsas, e se não falsas, opacas e místicas"13.
\end{abstract}

\footnotetext{
${ }^{11}$ Idem, ibidem, p. 80.

${ }^{12}$ Carlyle, T. Os heróis, p. 19-20. Título original em inglês: On heroes, hero-worship and the heroic in history.

${ }^{13}$ Hook, S. O herói na história, p. 20.
} 
E, de fato, não é mesmo fácil defendê-lo. O livro de Carlyle consegue cruzar com muita facilidade a linha do absurdo rumo a uma teoria da história que vai da idealização mística dos heróis mitológicos à crença sincera de que os grandes homens foram enviados à Terra pela providência divina. Influenciado pelo romantismo de Fichte, os valores, o passado e a história surgem no livro de Carlyle com um sentido religioso. A exasperação de Sidney Hook é perfeitamente compreensível.

Mas a reação final à concepção heróica da história virá com o desenvolvimento do determinismo social já presente em Hegel, pelo materialismo histórico de Marx. Se para Hegel "tudo o que é real é racional; tudo o que é racional é real", subscrevendo assim a verdade daquilo que é, para Marx, verdadeiro é aquilo que ainda virá a ser.

No seu trabalho sobre a "Sagrada Família", Marx já critica a concepção de história em Hegel por esta pressupor um "espírito abstrato" ou "absoluto" transportado de forma consciente ou inconsciente pela massa da humanidade. Avesso à metafísica, Marx acusa Hegel, portanto, de introduzir no interior da história empírica (exotérica) uma história especulativa (esotérica), convertendo assim a história da humanidade em uma história do espírito abstrato da humanidade, espírito este que estaria além do homem "real".

O que Marx tenta fazer é converter a "filosofia da história" em uma "ciência da história", através do método do materialismo histórico. Por isso ele afirma que

\footnotetext{
“As premissas de que nós partimos não são arbitrárias nem dogmas; são premissas reais, a partir das quais só na imaginação é possível formar abstrações. São os indivíduos reais, a sua atuação e as suas condições materiais de vida: as que encontram quando nascem, como as que são produzidas pela sua própria atuação. Essas premissas são, portanto, verificáveis duma forma puramente empírica" ${ }^{, 14}$.
}

Contra Hegel, Marx argumenta que seu método de abordar a história não se ocupa de explicar a prática material a partir da idéia, mas o oposto disso. Sendo assim, os produtos da consciência, as ideologias, não poderiam de forma alguma (como para o idealismo) serem dissolvidos pela crítica intelectual, mas apenas através da subversão (prática) que deram origem à ilusão idealista. Conclui-se daí que o importante não é a crítica, mas a revolução.

\footnotetext{
${ }^{14}$ Marx, K., Concepção materialista da história, in: Gardner, P. Teorias da história, p. 155.
} 
Por mais que Marx não se ocupe com o papel desempenhado pelos grandes homens nos rumos da história, não é difícil deduzir que sua posição quanto a isso assemelha-se à de Hegel: os indivíduos representam na história o papel que o "espírito da época" (no caso, as condições objetivas) exigem que ele represente.

A tarefa de discutir a importância do indivíduo na história a partir do materialismo histórico, neste primeiro momento, ficaria a cargo de Engels. Aí veremos também ecos do determinismo social hegeliano, quando Engels aponta que o surgimento de um homem em particular em uma determinada época e país é um evento fortuito, de pura casualidade. Necessário mesmo é a exigência, em determinado contexto histórico-social, do surgimento de um homem capaz de conduzir as mudanças que já estavam a caminho a despeito do seu conhecimento consciente desse processo revolucionário:

“Que Napoleão - esse corso em especial - tivesse sido o ditador militar tornado necessário pelas guerras exaustivas da República Francesa, foi uma questão de acaso. Mas na falta de um Napoleão, alguém teria tomado seu lugar, o que é comprovado pelo fato de que sempre que um homem foi necessário, ele foi encontrado: César, Augusto, Cromwell" $" 15$.

Mas, apesar da insistência de Marx na importância das condições objetivas, no fato de que é a vida que determina a consciência e não o oposto, e mesmo contando com o auxílio de Engels, a questão do papel desempenhado pelos grandes homens na história estava longe de ser solucionada em prol do materialismo histórico na consciência das massas e de alguns socialistas. Muitos enfatizavam a importância das decisões pessoais em detrimento do determinismo social. Como aponta Sidney Hook:

\footnotetext{
"O programa político e a filosofia dos Narodnik - populistas socialistas russos - eram supostamente baseadas na concepção de que a História podia ser influenciada de modo significativo por grandes heróis da palavra e, ainda mais, da ação. Este grupo e seu sucessor popular, o Partido Revolucionário Social, rejeitaram as concepções marxistas do determinismo e evolução social. Sem negar a influência de fatores materiais, sociais e econômicos, eles puseram ênfase ainda maior sobre as decisões pessoais e éticas na História. Negaram-se a repudiar o uso do terror individual como política para combater
}

\footnotetext{
${ }^{15}$ Engels, F. Carta a Starnenberg, citado por Hook, S., O herói na história, p. 71.
} 
a opressão. Consideraram indivíduos em posições-chaves, e não o 'sistema' que os criou, responsáveis por males sociais e excessos políticos"16.

Plekhanov bate-se em três frentes: contra os narodniks que se recusam a aceitar o determinismo social proposto por Marx e Engels, contra os defensores da Escola Heróica, e também contra os deterministas "radicais" que desconsideram totalmente a importância do indivíduo na história. Pela primeira vez depois de Hegel empreende-se uma tentativa verdadeiramente séria de conciliar duas tendências tão antagônicas, e a partir do materialismo histórico.

$\mathrm{O}$ argumento, que aqui chamaremos de a "equação de Plekhanov" resume-se da seguinte forma. Suponhamos que determinado evento histórico (A) tenha que ocorrer necessariamente a partir de determinada conjunção de eventos. Consideremos agora que parte desse número de circunstâncias já existe e que uma outra parte existirá em um dado tempo T. Pois bem, se eu, que estou familiarizado com o fenômeno A, reagir a essa situação cruzando os braços e esperando que o fenômeno A ocorra no tempo futuro $\mathrm{T}$, essa minha inação diminuirá a probabilidade da ocorrência do evento A. Isso se dá porque a soma $(S)$ de circunstâncias necessárias para a ocorrência de A incluía a variável $a$ correspondente à minha ação no tempo presente. Sendo assim, no tempo T o resultado da soma das circunstâncias necessárias à ocorrência de A será $S-a$. Mas, digamos que um outro indivíduo, que também estava em estado de inação, ao perceber a minha apatia, considere-a perniciosa. Essa percepção poderá arrancá-lo de sua própria inação, motivando-o à ação. E se a força de sua ação chamarmos de $b$; sendo $a=b$ o resultado da soma das circunstâncias favoráveis à ocorrência de A no tempo $\mathrm{T}$, continuará sendo $\mathrm{S}$, possibilitando assim a ocorrência futura de A.

Entretanto, surge aqui um inconveniente. Se a minha força $a$ for diferente de zero, se eu for um trabalhador hábil e capaz, ou se ninguém houver me substituído, então não teremos mais a soma $\mathrm{S}$ e (1): o fenômeno A não ocorrerá totalmente como supúnhamos; (2) ocorrerá mais tarde do que supúnhamos; ou (3) simplesmente não chegará a ocorrer.

Há ainda um segundo inconveniente. Ora, a previsão de que a soma $\mathrm{S}$ estaria completa no tempo T não levou em conta o fato de que eu iria me deitar a dormir após saber da predição. Quem fez a referida predição estava convencido de que eu não me entregaria à inação. Mas suponhamos que aquele que fez a predição pensou em tudo.

\footnotetext{
${ }^{16}$ Hook, S., O herói na história, p. 74.
} 
Retomemos então o raciocínio a partir da premissa preditiva inicial: a soma $\mathrm{S}$ estará completa no tempo T. A soma de circunstâncias $\mathrm{S}$ levará em conta a minha substituição como agente (por alguém menos competente que eu), mas incluirá também a ação estimulante em outros homens de que seus esforços e ideais seriam a expressão subjetiva de uma necessidade objetiva (consciência da necessidade). Neste caso, aponta Plekhanov, a soma $\mathrm{S}$ estará efetivamente completa no tempo $\mathrm{T}$ e o fenômeno $\mathrm{A}$ ocorrerá.

Sendo assim tão evidente esse raciocínio, por que é que a predição me pareceu um convite (ou uma condenação) à inação? Deixemos a resposta com o próprio Plekhanov:

\begin{abstract}
"Provavelmente, porque, devido às circunstâncias da minha educação, eu tinha já uma tendência muito forte para a inação e a minha conversa consigo [com o previsor] foi a gota que fez transbordar a taça desta louvável inclinação. É tudo. Só neste sentido como causa que denunciou a minha flacidez moral e a minha inutilidade - é que a consciência da necessidade aqui figura. Ela [a consciência da necessidade] não pode de modo algum ser encarada como a causa desta flacidez: as suas causas são as circunstâncias da minha educação"17.
\end{abstract}

A título de exemplo, Plekhanov aponta que a situação militar da França durante o reinado de Luís XV não era nada boa. Os oficiais franceses, quando destacados para sentinelas, abandonavam seus postos e só obedeciam aos seus superiores quando lhes era conveniente. Tal estado de coisas devia-se à decadência da aristocracia, que a despeito disso continuava a ocupar os postos mais elevados no exército. Isso já teria sido suficiente para um desenlace desfavorável para a França na Guerra dos Sete Anos. Mas a incompetência de alguns generais - como Soubise - aumentavam as chances de fracasso do exército francês. Como Soubise era protegido da poderosa Marquesa de Pompadour, que por sua vez submetia Luís XV aos seus caprichos, poderíamos considerar a influência da Marquesa como um dos "fatores" que acentuaram de forma desfavorável as causas gerais (decadência da aristocracia e conseqüente crise no exército) da situação na França.

Entretanto, Plekhanov nos recorda que a Marquesa de Pompadour só era poderosa porque o rei estava submetido às suas vontades, e não por conta de sua própria força. Tendo em conta o determinismo social, poderíamos afirmar que o caráter fraco de

\footnotetext{
${ }^{17}$ Plekhanov, G. O papel do indivíduo na história, in: Gardner, P. Teorias da história, p. 178.
} 
Luís XV era aquilo que deveria ser por conta mesmo do desenvolvimento das relações sociais na França? A resposta de Plekhanov é negativa. A fraqueza moral de Luís XV é entendida como algo contingente: um rei com uma atitude diferente para com as mulheres poderia ter surgido no lugar dele.

Após a batalha de Rosbach, os franceses se indignaram com a proteção a Soubise e, apesar dos constantes insultos, a Marquesa de Pompadour continuava a protegê-lo. Por que ela não cedia à opinião pública? Plekhanov pergunta e ele mesmo responde: "provavelmente porque a sociedade francesa daquele tempo não tinha meios para obrigá-la a ceder. Impedia-a disso a sua forma de organização que, por seu turno, era determinada pela correlação das forças sociais em França ao tempo" ${ }^{\prime 18}$. E conclui então que nem o "fraco" de Luís XV pelas mulheres e nem a vaidade da Marquesa de Pompadour teriam sido os fatores determinantes do destino deplorável da França. Qualquer conclusão que não fosse esta estaria flagrantemente em desacordo com o caráter monista do materialismo histórico. E é exatamente essa necessidade de manter a coerência que faz com que os argumentos de Plekhanov sejam um tanto contraditórios.

Ele afirma que é, de fato, inegável o efeito na história das peculiaridades de determinados indivíduos, mas aponta que tal efeito só exerceria o seu poder a partir da correlação de forças no interior de determinada sociedade, ou seja, o caráter de um indivíduo só seria um "fator" no desenvolvimento social se as relações sociais assim o permitissem. Tal influência também guardaria relação com o talento individual, mas um indivíduo só poderia manifestar seu talento (de forma a influenciar o curso de determinados acontecimentos) se ocupasse alguma posição de destaque no interior da sociedade. O destino da França estava nas mãos de um monarca fraco porque a forma de organização da sociedade francesa permitia isso.

A possibilidade de que os indivíduos exerçam influência sobre os rumos da história, como bem aponta Plekhanov, abre as portas desta ao acaso. A lascívia de Luís $\mathrm{XV}$, argumenta ele, era algo casual no que dizia respeito ao curso geral do desenvolvimento da França (por ser fruto da constituição física do monarca), no entanto, isso influiu no destino da sociedade francesa. $\mathrm{O}$ mesmo poderíamos afirmar quanto à morte de Mirabeau, devida a causas patológicas que seguiam regras naturais definidas. Em ambos os casos, tais vicissitudes não tiveram origem no curso geral do desenvolvimento da França, sendo assim casuais. Mas nem por isso deixaram de

${ }^{18}$ Idem, Ibidem, p. 190 
exercer alguma influência no rumo dos acontecimentos. Conclui-se daí que, algumas vezes, o destino das nações depende dos acasos, o que não impede que tais processos sejam estudados pela ciência.

Tendo tudo isso em conta, somos levados a concluir que Plekhanov conseguira solucionar parte do problema de forma satisfatória, sem grandes contradições, mas não é o que ocorre. Ele reabilita o papel do indivíduo na história e reinstaura aí a influência sempre problemática do acaso, para logo em seguida negar-lhes qualquer importância, retornando à ortodoxia marxista. Isso ao afirmar que, no final das contas, não importam as pequenas causas fisiológicas ou psicológicas em questão, os processos históricos sobre os quais elas exerceriam sua força ocorreriam de qualquer forma:

\footnotetext{
"Sainte-Beuve pensava que se tivesse havido um mínimo suficiente de causas menores e obscuras do tipo das que ele mencionou, o desenlace da Revolução Francesa teria sido o contrário daquele que conhecemos. Isso é um grande erro. Por mais inextricavelmente enredadas que tivessem sido as pequenas causas psicológicas e fisiológicas, em caso algum teriam eliminado as grandes necessidades sociais que deram origem à Revolução Francesa; enquanto estas necessidades estivessem por satisfazer, o movimento revolucionário em França teria continuado. Para tornar o desenlace deste movimento contrário ao que foi, as necessidades que lhe deram origem teriam de ter sido o contrário do que foram; e isto, é evidente, nenhuma combinação de causas menores teria conseguido" $" 19$.
}

Ou seja, indivíduos talentosos podem até alterar algumas características dos eventos históricos ou algumas de suas conseqüências particulares, mas jamais a sua orientação geral que é determinada pelas relações sociais. Tal consideração faz com que a conclusão a que Plekhanov chega seja a mesma de Engels e Hegel: não fosse Napoleão, algum outro aventureiro teria tomado o seu lugar.

E é mesmo tendo isso em mente que ele discute a impressão que temos de que sem os grandes homens a história não teria sido como foi. Essa "ilusão de óptica" ele atribui ao fato de que, no caso de Napoleão, este, ao desempenhar o seu papel de protetor da ordem pública, impediu, barrou o acesso de outros que poderiam ter desempenhado essa mesma função talvez tão bem quanto ele. Sendo assim, a força de Napoleão nos parece muito ampliada hoje porque as outras forças que poderiam ter ocupado o seu lugar não passaram da potência ao real. Por isso, "quando nos

\footnotetext{
${ }^{19}$ Idem, ibidem, p. 192-193.
} 
perguntaram: 'Que teria acontecido se não tivesse existido Napoleão', a nossa imaginação atrapalha-se e parece-nos então que sem ele não teria ocorrido o movimento social em que assentaram o seu poder e a sua influência" ${ }^{20}$. Mas, é fato, não poderia ter sido qualquer um a tomar o lugar de Napoleão. Para que qualquer indivíduo de talento consiga influenciar o curso dos eventos históricos, é necessário (1) que seu talento o adapte às necessidades sociais da época e (2) seu caminho não pode ser obstruído pela ordem social existente.

O historiador Sidney Hook rejeita a tentativa de síntese de Plekhanov, que não consegue escapar do determinismo social ao afirmar a importância dos grandes líderes para então retornar à ortodoxia marxista. Hook pretende discutir a importância do herói na história sem recair no misticismo de Carlyle e nem negar a importância das forças sociais. Para Hook, a dificuldade consiste em descobrir quando o herói seria um "acidente" histórico e quando ele seria um verdadeiro agente de mudança. É fato que na história tanto quanto na natureza podemos notar que determinados eventos estariam mais significativamente ligados entre si do que outros. Citando o exemplo de Colombo e do descobrimento da América, ele nota que, apesar da sua importância como desbravador, nenhum historiador estaria disposto a admitir que sem Colombo a América não teria sido descoberta e que a história desse continente teria sido completamente diferente daquilo que é hoje. A expansão do capitalismo e a busca de novos mercados consumidores a leste, bem como o interesse quanto a uma passagem mais curta para a Índia certamente motivariam outros desbravadores. Ou seja, graças às tendências "determinantes" em ação na história social da Europa resultariam no descobrimento do novo mundo mesmo se Colombo nunca tivesse existido. Seria apenas uma questão de tempo. Sendo assim, Colombo, Vespúcio, Magalhães, etc., não poderiam ser considerados heróis históricos.

Para Hook, portanto, aquilo que define a importância de uma ação heróica significativa é a existência de possíveis alternativas de desenvolvimento em determinada circunstância histórica (bifurcações). Nisso ele concorda com os deterministas sociais: quando a magnitude de determinada situação histórica é suficientemente forte, não há nada que possa detê-la. Entretanto, em determinadas circunstâncias, quando duas ou mais alternativas são historicamente possíveis,

\footnotetext{
${ }^{20}$ Idem, ibidem, p. 196.
} 
determinados indivíduos poderiam fazer a balança da história pender para algum dos lados.

\begin{abstract}
"Sempre que estamos em posição de asseverar (...) que um homem momentoso teve influência decisiva num período histórico, não estamos abandonando a crença na conexão causal ou abraçando a crença na causalidade absoluta. O que afirmamos é que em tais situações o grande homem é uma influência histórica relativamente independente - independente das condições que determinam as alternativas - e que nessas ocasiões a influência de todos os outros fatores relevantes têm peso secundário no capacitar-nos para entender ou predizer qual das alternativas possíveis será efetivada. Em tais situações deveríamos também ser capazes de dizer, e de apresentar as razões para dizê-lo, que se o grande homem não tivesse existido o curso dos acontecimentos teria, com toda probabilidade, tomado uma direção diferente" ${ }^{\text {,21. }}$.
\end{abstract}

$\mathrm{Na}$ intenção de defender sua tese, Hook reabilita a importância epistemológica do "se" na pesquisa historiográfica. A legitimidade de sua tese consiste na legitimidade de perguntas como: "que ocorreria se esse fato não tivesse acontecido ou se aquele homem não tivesse vivido ou se esta alternativa não tivesse sido tomada"22.

Mas ele não tem em mente a reabilitação da condicional às expensas da realidade. Existem reconstruções históricas verossímeis e outras absolutamente fantasiosas. A discussão em pauta é a de que nem todo "se" implica em mera fantasia inútil de historiadores ociosos ou em ficção ao invés de historiografia, porque nem todas as possibilidades históricas são igualmente plausíveis. Para tanto, ele cita o exemplo da reforma e da contra-reforma. Se a primeira não tivesse acontecido seria possível prever com segurança a não-ocorrência da segunda. Entretanto, seria muito mais difícil tentarmos prever o que teria acontecido no desenvolvimento do cristianismo se não tivesse havido a reforma protestante, porque "quando estendemos a linha da possível eventualidade muito além do período imediato, a mente vacila sob o peso cumulativo do imprevisto. Eis porque a profecia é uma vocação tão perigosa",23.

Esses "poderiam ter sido" da história surgem então como possibilidades perdidas, que não ocorreram, na maior parte das vezes, por falta de inteligência (sobretudo quanto às possibilidades objetivas do bem) mas, algumas vezes, pela falta de um herói.

\footnotetext{
${ }^{21}$ Hook, S. O herói na história, p. 100.

${ }^{22}$ Idem, ibidem, p. 101.

${ }^{23}$ Idem, ibidem, p. 115.
} 
Ele distingue, assim, a existência de dois tipos de heróis: o homem-momento e o homem-época. Tanto um tipo quanto o outro surgem em um momento de bifurcação na história, onde a possibilidade de ação desses homens já foi preparada pela direção de acontecimentos pregressos. No caso do homem-momento, tal preparação estaria em um estado já muito avançado e exigiria apenas um pouco de talento e sorte, mas não uma grande ação por parte dele para que o curso da história seguisse por determinado ramo da bifurcação. O homem-época, por sua vez, é uma espécie de homem-momento cujas ações são norteadas mais pela sua inteligência e força do caráter que por circunstâncias felizes do acaso.

“A diferença é a seguinte: no caso do homem-momento, a preparação está num estado muito avançado. É preciso um ato relativamente simples - um decreto, um comando, uma decisão sensata - para fazer a escolha decisiva (...). O homem-época, por outro lado, encontra uma bifurcação na estrada da história, mas ajuda também, por assim dizer, a criá-la. Aumenta as probabilidades de sucesso para a alternativa que escolhe em virtude das qualidades extraordinárias que possui para realizá-la"24.

Para Hook, uma outra característica distintiva destes dois tipos de heróis é o fato de que o homem-época tem certa consciência da seqüência de acontecimentos a que sua decisão dará origem. Convém notar, porém, algumas coisas. Não é simples distinguir quando determinado personagem histórico enquadra-se na categoria de homem-época ou de homem-momento; isso dependeria muito da análise da situação. Outro ponto a ser considerado é que tal categorização representa (mesmo que Hook não utilize essa expressão) "tipos ideais" no sentido weberiano mesmo, ou seja, dificilmente nós os encontraríamos em uma forma pura. E o mais importante: existem situações que nenhum herói pode dominar.

A análise de Sidney Hook é muito intrigante e a sua distinção entre homemmomento e homem-época nos parece adequada, sobretudo quando consideramos a ressalva de que a distinção entre um tipo e outro dependeria da análise da situação. No caso que aqui nos interessa - o nazismo - existe uma figura que naturalmente se sobressai: Adolf Hitler. A pergunta que se tem feito ao longo de décadas é a seguinte: "Não fosse Hitler, teria acontecido a Segunda Grande Guerra e conseqüentemente o holocausto?". Notemos que assim formulada, a dúvida oculta a presença de duas

${ }^{24}$ Idem, ibidem, p. 132-133. 
questões distinas, apresentando-as como se fossem apenas uma. Melhor seria perguntarmos: (1) Não fosse Hitler, o mundo teria sido conduzido a um conflito global? e (2) Não fosse ele, teria sucedido o holocausto?

A resposta à primeira pergunta, se aceitarmos a concepção "heróica" da história de Carlyle seria não, pois a história, ele argumentaria, é forjada por esses homens superiores. Hegel consideraria Hitler um indivíduo "histórico-cósmico", capaz de apreender a realidade e os desejos de sua época (inconscientemente), realizando apenas aquilo que já estava maduro e agindo de acordo com o "espírito da época", ou seja, não fosse ele, o "ardil da razão" teria encontrado uma outra solução para realizar seu projeto. Quanto a Kant, a questão seria um pouco mais complicada, mas não é difícil imaginar que, de acordo com o "plano oculto" da natureza, a história teria que seguir esse curso de qualquer forma, independente do indivíduo. Difícil seria harmonizar o nazismo com a concepção kantiana de que a história humana seguiria um curso regular da animalidade à humanidade, problema também difícil de solucionar em Hegel, igualmente convicto de que a história caminha rumo ao progresso. Em Herder a finalidade seria a mesma, mas sua identificação com o devir histórico que conduziria ao Estado nazista, graças à sua crença no "gênio dos povos" seria mais imediata: Hitler agiria de acordo com o caráter de seu povo, mas é difícil dizer (como em Kant) se ele seria dispensável. Quanto a Engels e Marx, não há muito o que discutir: sempre que as condições objetivas exigem, o grande homem é encontrado, ou seja, na falta de Hitler seria algum outro ditador.

Foi essa concepção (apesar da mística em torno de Hitler) que prevaleceu na análise do conflito que culminou com a Segunda Guerra Mundial. O argumento já conhecido de todos é aquele da humilhação alemã pelo Tratado de Versalhes, que pôs fim à Primeira Guerra Mundial mas ao mesmo tempo foi a causa do início da Segunda Guerra Mundial. A Polônia independente foi partilhada, no final do século XVIII, pela Prússia, Áustria e Rússia, sendo reconstituída após a Primeira Guerra Mundial sobre parte do território alemão, que foi obrigado a ceder à Polônia uma saída para o mar (Posnânia), quebrando assim a continuidade de seu território. O resultado do Tratado de Versalhes foi a criação do "corredor polonês", a perda da Alsácia e Lorena, o fím do serviço militar obrigatório e a redução do exército alemão para apenas 100.000 homens (além da proibição da aviação, blindados e artilharia pesada) e a perda do rico território do Sarre, que passou para o comando da Liga das Nações por 15 anos. Responsabilizada pela guerra, a Alemanha foi obrigada a arcar com uma dívida de guerra impagável e se 
não honrasse seus compromissos poderia ter a região do Ruhr confiscada pela França, o que acabou acontecendo.

Se levarmos em conta a solução encontrada por Plekhanov, devemos apontar que a "orientação geral", ou seja, a guerra inevitável seria fruto dessas "relações sociais". Em outros termos, dadas as condições objetivas necessárias (e supostamente suficientes), o conflito não poderia ser evitado. Mas Plekhanov deixa indicada a possibilidade de alterações nas características de determinados eventos históricos, ou melhor, em suas "conseqüências particulares".

Somos capazes de aceitar o fato de que naquelas circunstâncias a orientação geral do evento histórico não poderia ser alterada, mas é aí que chegamos à nossa segunda pergunta: não fosse Hitler, o holocausto teria acontecido? Mais ainda: não fosse esse indivíduo em especial, a evolução dessa orientação geral não poderia ter sido abortada após a reunião do Sarre ao Reich em 1935 ou o Anschluss (união da Áustria à Alemanha) de 1938? Agora que reabilitamos o "se" na história, autorizados por Sidney Hook, podemos prosseguir com o raciocínio.

Pois bem, aquilo que mais nos intriga no caso do holocausto, além do horror da coisa mesma, é a radicalidade de uma solução (o extermínio) absolutamente desnecessária em termos estratégicos e absurdamente complicada quanto à sua logística. A primeira solução rumo a uma Alemanha judenfrei (livre de judeus) foi a idéia de uma emigração forçada para uma reserva próxima a Nisko, na Polônia central ocupada. A idéia era criar aí um estado judaico autônomo na forma de um protetorado, projeto que fracassou totalmente. Depois disso, veio o "projeto Madagascar" 25 . Também idealizado por Eichmann, como fôra a solução Nisko, o projeto Madagascar pretendia evacuar 4 milhões de judeus da Europa para essa ilha francesa no sudeste da África. A idéia, aponta Hannah Arendt, já havia sido pensada pelo governo polonês em 1937, que chegou à conclusão que seria absolutamente impossível embarcar seus quase 3 milhões de judeus para a ilha. Não se sabe ao certo se Eichmann acreditou mesmo ser possível uma evacuação em massa dessa magnitude, através do bloqueio naval britânico que controlava o Atlântico, ou se o plano não passava de um embuste, uma cortina de fumaça para encobrir a solução final.

Considerado obsoleto, o projeto Madagascar foi abandonado pela solução do extermínio físico. O problema era como matar pessoas em larga escala e depois livrar-se

\footnotetext{
${ }^{25}$ Sobre isso, conferir Arendt, Hannah. Eichmann em Jerusalém: um relato sobre a banalidade do mal, p. 90-92.
} 
dos corpos da maneira mais "racional" possível com um gasto mínimo de recursos. A primeira solução foram os fuzilamentos, mas carregar os corpos e depois enterrá-los consumia tempo, por isso as valas passaram a ser cavadas e os judeus eram obrigados a se amontoar nessas valas e então eram fuzilados. Um novo grupo chegava e, caminhando sobre os corpos que jaziam nas valas, encontravam um lugar para deitar e depois eram fuzilados, assim sucessivamente, camada após camada. Mas logo o fuzilamento foi substituído pelo envenenamento com gás, muito mais eficiente.

O próprio Rudolf Hoess (não confundir, como se faz com frequiência, com Rudolf Hess, vice-líder do partido nazista), tenente general da SS a partir de 1942 e comandante do lendário campo de concentração de Auschwitz entre 1940 e 1943 esclareceu como funcionava esse novo método de extermínio em massa, em entrevistas a Leon Goldensohn, psiquiatra da prisão em Nuremberg ${ }^{26}$. Segundo o relato de Hoess, a ordem para a solução final teria sido dada por Himmler no verão de 1941. Quando os primeiros transportes chegaram a Auschwitz, duas velhas casas de fazenda já haviam sido convertidas em câmaras de gás, onde 1800 a 2000 pessoas poderiam ser mortas de cada vez com gás Zyklon B. Como a construção dos crematórios não acompanhava o ritmo da matança, os corpos eram inicialmente cremados em fossos ao ar livre, onde se alternava uma camada de corpos e outra de lenha. Quando os fornos ficaram prontos eles funcionavam 24 horas por dia e mesmo assim não era suficiente. Os dados do extermínio são impressionantes: algo em torno de 20.000 mortos diariamente.

Uma obra dessa magnitude era muito dispendiosa, mobilizando milhares de soldados alemães, dezenas de oficiais, ou seja, tempo e recursos humanos e financeiros justamente no momento em que o exército alemão enfrentava terríveis baixas na guerra contra a Rússia. O extermínio dos judeus, muitos deles profissionais liberais, comerciantes e banqueiros, só poderia agravar o colapso do sistema financeiro, além de desestruturar a produção industrial. Mas nada disso importava porque os fins eram refratários a esse tipo de considerações racionais. Não se tratava, como na maioria das guerras modernas, de dominar vastos territórios e explorar seus recursos naturais. Não interessava nem mesmo reforçar essa exploração com a utilização de mão de obra escrava, porque os judeus não serviam sequer para serem utilizados como escravos. E nem mesmo o projeto de dominação global, típico de qualquer nação expansionista, exigiria o extermínio de toda a população dominada.

\footnotetext{
${ }^{26}$ Goldensohn, L. As entrevistas de Nuremberg, p. 352-358.
} 
Nenhuma consideração calcada "no modo de produção da vida material" é capaz de explicar esse tipo de projeto de dominação. As condições objetivas capazes de ditar o caráter geral dos processos de vida social não tinham (pelo menos nesse caso) como conseqüência lógica a aniquilação total. O holocausto pode ser considerado irracional mesmo se considerarmos como única forma de racionalidade a lógica do capital, porque de acordo com essa lógica são necessários produtores e, sobretudo, consumidores, pouco importando se esses consumidores possuem sangue nobre ou plebeu. Não há luta de classes entre burguesia e operariado que explique a obsessão de Hitler com a pureza racial. Ele não inventou o anti-semitismo, mas talvez sem ele o projeto (que por pouco não foi realizado) de uma nova raça de senhores jamais teria sido concebido com tanta clareza e executado com tanta eficiência. Eis aí as "consequiências particulares" a que se referira Plekhanov, como se isso fosse algo absolutamente irrelevante. Algumas peculiaridades individuais podem tornar mais (ou menos) desastrosa a orientação geral dos eventos históricos, afinal, neste caso, se substituíssemos Hitler por Napoleão a diferença seria a inexistência de campos de extermínio.

Isso nos conduz diretamente à Psicologia individual dos grandes líderes, mas não pretendemos subscrever a idealização mística dos grandes homens preconizada por Carlyle. Este trabalho pretende mostrar que um conjunto de idéias, místicas (como o caso da ariosofia) ou científicas (como o caso da eugenia) podem ter encontrado em determinados homens (Lanz, List, Hitler, Himmler) terreno fértil para germinar, convertendo assim aquilo que em Carlyle seria considerado mera peculiaridade de um indivíduo excepcional em um problema de Psicologia Social.

Sabemos que Freud, na última das conferências introdutórias, e apesar das críticas ao comunismo esboçadas em "O mal-estar na civilização", nota bem a força do marxismo ao enfocar a influência das "circunstâncias econômicas" sobre a vida dos homens em sociedade:

\footnotetext{
“a força do marxismo está, evidentemente, não em sua visão da história, ou nas profecias do futuro baseadas nela, mas sim na arguta indicação da influência decisiva que as circunstâncias econômicas dos homens sobre as suas atitudes intelectuais, éticas e artísticas. Com isso foram descobertas numerosas correlações e implicações, que anteriormente haviam sido quase totalmente negligenciadas" ${ }^{27}$.
}

\footnotetext{
${ }^{27}$ Freud, S. Novas conferências introdutórias.
} 
O embate entre Weber e Marx também vai por esse mesmo caminho. Em contraste com este, Weber se recusa a aceitar que as idéias (como em Nietzsche e Marx) seriam apenas reflexos da dinâmica social ou da psicologia individual, supondo que as diferentes esferas (econômicas, religiosas, intelectuais ou psíquicas) seguiriam, pelo menos em parte, uma evolução própria. Ele tenta equilibrar, sempre que possível, as influências psicológicas e as influências históricas, operando, diferentemente de Marx e Nietzsche, com o conceito de "afinidade eletiva" em detrimento dos conceitos de "reflexo" ou "expressão", ou seja,

“Para Marx, as idéias 'expressam' interesses, assim, o Deus oculto dos puritanos expressa a irracionalidade e anonimidade do mercado. Para Nietzsche, o cristianismo ascético 'reflete' o ressentimento dos escravos, que assim 'expressam' sua 'revolta na moral'. Para Weber, não há ligação íntima entre os interesses ou a origem social do sujeito e seu séqüito e o conteúdo da idéia, em seu início"28.

Em resumo, tanto Nietzsche quanto Marx tomam as idéias não como capazes de portar um valor intrínseco, mas sempre como derivadas de interesses outros, psicológicos ou materiais. Era essa divergência com o materialismo histórico que Weber tinha em mente ao escrever A ética protestante e o espírito do capitalismo, ou seja, ele pretendia ressaltar a autonomia das idéias (frente às condições materiais e a luta de classes) no surgimento do capitalismo moderno, que exigia um tipo específico de personalidade conseguida a partir da crença em um conjunto de idéias que mesmo de forma involuntária serviram para criar os traços de personalidade necessários para o desenvolvimento do capitalismo. Esse conjunto de crenças estava reunido na ética protestante, sobretudo do calvinismo. De acordo com Weber a doutrina calvinista da predestinação dava origem ao problema de como o fiel poderia ter certeza de que era um dos eleitos, já que, segundo essa doutrina, Deus havia escolhido desde o início aqueles que seriam brindados com a salvação e todos os que seriam punidos com a danação. Para a maioria dos homens era impossível não pensar em uma forma segura de descobrir se ele fazia parte ou não do grupo de eleitos, e uma das formas recomendadas era que se mantivesse a autoconfiança (na eleição) e para isso "uma intensa atividade profissional era recomendada, como o meio mais adequado" ${ }^{29}$.Esse conselho baseava-se no argumento do próprio Calvino, que ao tornar lícitas as práticas do capitalismo, como

\footnotetext{
${ }^{28}$ Weber, M. Ensaios de sociologia, p. 81-82.

${ }^{29}$ Weber, M. A ética protestante e o espírito do capitalismo, p. 77.
} 
o empréstimo a juros, apontava que mesmo o comerciante que buscava o lucro (através do trabalho, da sobriedade e da ordem) estaria também respondendo ao chamado de Deus. Ou seja, a prosperidade econômica, de forma implícita, surgia aí como um "indício" de eleição. E juntamente com o ideal ascético, que condenava a ganância instintiva e o gasto desnecessário com luxo, estimulando a poupança, decorreu daí a acumulação capitalista. Weber conclui, portanto, que "as restrições impostas ao uso da riqueza adquirida só poderiam levar a seu uso produtivo como investimento de capital" ${ }^{\prime 3}$. Eis aí uma forma diametralmente oposta à sugerida por Marx (que apostava na transformação das relações de produção no campo) de explicação da acumulação primitiva que teria fornecido as condições necessárias para o surgimento do capitalismo.

Weber entendia perfeitamente e até aceitava o argumento de que os interesses materiais e não as idéias governavam a conduta humana, mas não deixava de notar, logo em seguida, que as "imagens mundiais" (construções simbólicas associadas às condições sociais de camadas específicas da população) criadas por "idéias" muito freqüentemente determinaram as linhas ao longo das quais a ação fôra impulsionada pela dinâmica dos interesses.

$\mathrm{O}$ argumento de Freud, expressado mais ou menos na mesma época das críticas de Weber, revelam essa mesma preocupação com a monocausalidade da análise marxista, que supervaloriza os fatores econômicos: "Não se pode, contudo, supor que os motivos econômicos sejam os únicos que determinam o comportamento dos seres humanos em sociedade" ${ }^{, 31}$. Freud acredita que as ilusões da consciência são produzidas por um pensamento que se julga livre quando na verdade seria prisioneiro de seus afetos (as pulsões) e defendendo seu ponto de vista contra Marx, argumenta:

\footnotetext{
"é completamente incompreensível como os fatores psicológicos podem ser desprezados, ali onde o que está em questão são as reações dos seres humanos vivos; pois não só essas reações concorrem para o estabelecimento das condições econômicas, mas até mesmo apenas sob o domínio dessas condições é que os homens conseguem pôr em execução seus impulsos instintuais originais - seu instinto de autopreservação, sua agressividade, sua necessidade de serem amados",32.
}

\footnotetext{
${ }^{30}$ Weber, M. A ética protestante e o espírito do capitalismo, p. 124.

${ }^{31}$ Freud, S. Novas conferências introdutórias.

${ }^{32}$ Idem. Ibidem.
} 
A convicção que moveu esse trabalho, apesar do nosso apreço por Marx, é a mesma que moveu Freud e Weber: a de que idéias e fantasias podem em determinadas circunstâncias mover a roda da história. Mas isso não significa que iremos negligenciar as "condições objetivas", a "força material”, apenas concordamos com Reich quando este afirma que se uma ideologia repercute sobre o processo econômico, isso é um sinal de que ela mesma se converteu em uma força material ${ }^{33}$.

Acreditamos que além das condições materiais, outras forças atuaram (e aqui fazemos uma concessão justa) sobre as "características particulares" da Segunda Guerra Mundial, pois como insiste Damergian com muita propriedade, a realidade psíquica e a realidade social estão intimamente relacionadas e em permanente interação, tendo em vista que há um psíquico no social e um social no psíquico (cada um com suas especificidades), já que através "dos mecanismos de introjeção e de projeção, de identificação introjetiva e projetiva, interno e externo, psicológico e social interagem”, impregnando a vida social de aspectos inconscientes, desmistificando assim a idéia de um social vazio de pulsões. ${ }^{34}$

Uma dessas "forças" teria sido a personalidade do próprio Hitler, faceta que não pretendemos discutir neste trabalho por julgarmos sempre temerário "psicologizar" personagens históricos já defuntos, e por julgarmos que isso já foi feito de forma exaustiva a partir dos anos 1950, e muitas vezes leviana. A segunda força motriz das referidas características particulares pensamos ter sido as idéias difundidas na Alemanha a partir dos grupos ocultistas, bem como aquelas da ciência eugênica. Pensamos que ao escolher essa faceta do problema ingressamos em um campo ainda pouco explorado e que por suas características serve muito bem como objeto de análise da Psicologia Social, disciplina sempre empenhada em escapar (mas raramente conseguindo) tanto da tentação de psicologizar o social quanto da tentação de sociologizar o mundo psíquico.

\footnotetext{
${ }^{33}$ Reich, W. Psicologia de massas do fascismo, p. 17.

${ }^{34}$ Damergian, Sueli. Para além da barbárie civilizatória: o amor e a ética humanista, p.88.
} 


\section{CAPÍTULO II: A MITOLOGIA GERMÂNICA}

"O mito conta uma história sagrada; ele relata um
acontecimento ocorrido no tempo primordial, o
tempo fabuloso do principio."

(Mircea Eliade)

“... o mito não é uma vã rapsódia, não é um mero brotar de fantasias frívolas, mas uma força cultural laboriosa e extremamente importante"

(Malinowski)

A antiga tradição pagã sobreviveu em poucos escritos que remontam ao ano 1000 d.C., e chegaram até nós não totalmente livres de influências cristãs. Enquanto a campanha de cristianização do império romano se expandia pelo continente europeu, navegadores noruegueses do século IX partiam rumo à colonização da Islândia levando consigo suas velhas divindades pagãs. Um século depois, porém, a expansão do cristianismo já alcançava a distante ilha, convertendo assim o paganismo.

Mas as fontes não são todas islandesas. A Inglaterra também preservou um tesouro da literatura anglo-saxônica, que narra as aventuras de um herói escandinavo. $\mathrm{O}$ épico Beowulf, escrito por volta do ano 1000, muito depois da cristianização da Inglaterra, traz importantes informações acerca do mundo medieval do norte da Europa e sobretudo de suas tradições aristocráticas. Entretanto, serão às fontes islandesas que prestaremos mais atenção.

Os missionários católicos, os quais não prezavam a tradição pagã, foram os responsáveis pela sobrevivência dos poucos manuscritos de que temos conhecimento sobre o velho paganismo. Mas muitos desses relatos foram conscientemente alterados nos pontos em que os monges julgavam atentatórios à moral cristã. Sendo assim, elementos da tradição pagã são alterados ou omitidos ao gosto do cristianismo, pelo menos até um pouco antes de 1643, quando se encontra, em uma antiga granja abandonada, uma coleção de antigos poemas mitológicos que narram as peripécias de seres sobrenaturais da mitologia germânica - deuses, anões, gigantes e dragões. Tais manuscritos, conhecidos como Edda poético ou antigo, parecem ter sido compilados 
pelo sacerdote islandês Soemund Sigfusson, por volta do século XI. Como aponta Meleiro:

"Vivendo na Islândia em finais do século XI (1056-1133), Soemund, que pertencia a uma família de origem norueguesa, aplicou-se a reunir as tradições do paganismo escandinavo que a Igreja se esforçava por fazer desaparecer, por o considerar de inspiração diabólica. Esse interesse tão vivo pela memória de um culto maldito valeu-lhe a reputação de feiticeiro a sobrepor-se à sua fama de grande sábio”"1.

No mesmo ano de sua descoberta, esse pequeno tesouro arqueológico de apenas 45 folhas é copiado em pergaminho a pedido do bispo Brynjolf, cópia esta que será perdida. Vinte anos depois, o mesmo bispo presenteia o rei da Dinamarca com o manuscrito original que passará a ser conhecido como Codex Regius.

Porém, mesmo antes da descoberta do manuscrito de Soemund, já se conhecia um tratado do século XIII, escrito em islandês por Snorri Sturluson, e que hoje é nossa principal fonte acerca da mitologia do norte da Europa. Conhecido como Edda em prosa, o texto de Sturluson é bem mais recente que o Codex Regius. Apesar de sua descoberta no século XVII e de sua compilação no século XI, as poesias do Codex parecem remontar ao século VIII, tempo em que já se falava o antigo nórdico.

\section{A cosmogonia dos antigos mitos germânicos}

No início, não era o "verbo", mas uma espessa massa de gelo ao norte de um abismo primordial, o Ginnungagap. A sul do abismo havia Mispell, o país do fogo. Da fusão entre gelo e fogo surgiram gotículas de água que deram origem ao gigante Ymir. Sob os seus braços surgiram o primeiro homem e a primeira mulher, e de seus pés surgiram a família dos gigantes do gelo. Ymir alimentava-se do leite de uma vaca primordial chamada Auðhumla, que ao lamber os blocos de gelo deu origem a um novo ser, um homem chamado Buri, que deu origem a Bor. Com os seus três descendentes (Óðinn, Vili e Vê), Bor dará origem à raça dos deuses - os AEsirs. Juntos, os primeiros deuses assassinaram Ymir, e seus filhos morreram afogando-se em seu sangue. Todos menos um: o gigante Bergelmir. Do desmembramento do cadáver de Ymir surgirá o mundo dos homens; da inundação causada por seu sangue, o mar e os lagos; da sua

\footnotetext{
${ }^{1}$ Meleiro, M. L. A mitologia dos povos germânicos, p. 50.
} 
carne, a terra; de seus ossos, as montanhas; de seus dentes e maxilares quebrados surgiram as rochas e os pedregulhos. De sua cabeça os deuses fizeram a cúpula do céu, que se mantinha firme sustentada por quatro anões. Esse mundo dos homens - Miðgarð - era protegido das investidas dos anões por uma muralha construída a partir das sobrancelhas de Ymir.

No centro do mundo, uma árvore gigantesca - Yggdrasil - o freixo sagrado, unia os dois mundos e sustentava todo o universo. Não sabemos as origens de Yggdrasil, mas sabemos que esse pilar do mundo possuía três raízes principais que mergulhavam em três fontes diferentes. Uma delas atingia a fonte Urd, a terma sagrada do destino, guardada pelas três Nornas, conhecedoras do passado, presente e futuro e por isso guardiãs do destino do mundo. Essas três donzelas eram Urdur (passado ou destino), Verdandi (ser ou presente) e Skuld (necessidade ou futuro), e todos os dias elas regavam a árvore Yggdrasil. A segunda raiz descia até Niflheim, a morada da escuridão, país do gelo e das trevas, até atingir Hvergelmir, cujas águas espalhavam-se por toda a terra formando os rios do mundo. A terceira e última raiz mergulhava rumo à Fonte da sabedoria, situada no país dos gigantes e guardada pelo sábio Mimir. Enroscada nas raízes de Yggdrasil encontra-se uma enorme serpente chamada Midgard - a serpente do mundo, mais antiga que os deuses e de cuja cólera se formam as ondas do mar. No topo de Yggdrasil, em seu ramo mais alto, estava pousada uma águia (em cuja testa pousava um gavião), cujo bater de asas formava os ventos do mundo. E como a águia e Midgard estavam brigados, um esquilo transitava das raízes ao topo da árvore transmitindo os insultos de uma para a outra. Enquanto isso as folhas de Yggdrasil eram continuamente devoradas por diversas criaturas: veados, cabras, etc.

Depois de criado Miðgarð - o mundo dos homens - era tempo de se criar Ásgarð, o reino dos deuses. Constantemente ameaçada pelos gigantes, Ásgarð possuía inúmeros saguões onde os deuses habitavam. Uma dessas moradas, Válaskjálf, com vista para todos os mundos ao mesmo tempo, morava Óðinn. Entretanto, a mais famosa e importante morada de Óðinn - o deus da batalha - era Valhala, o Palácio dos Aniquilados, onde eram recebidos todos os guerreiros caídos em batalha. Todas as noites Óðinn servia um banquete no Valhala, com carne de porco que nunca acabava e hidromel, uma bebida preciosa feita com o sangue do sábio Kvasir e adoçada com mel, capaz de inspirar quem o bebesse. Os guerreiros mortos, recolhidos nos campos de batalha, eram conduzidos a Valhala pelas virgens do deus da guerra - as Valkyrja ("a que acolhe os derrotados"). 


\section{Os deuses e os mitos}

Em uma sociedade guerreira, não é de se estranhar que o mais importante do panteão de deuses seja aquele ligado à guerra. A mors triumphalis - crença de que a boa morte consiste em morrer em combate - fez de Óðinn, líder dos Æsirs e senhor da guerra, a mais importante divindade do norte da Europa. Não é incomum ouvirmos também os nomes Wodan ou Wotan, e até mesmo Tîwaz associados à guerra. Ao que parece, Óðinn seria um sucessor no tempo das divindades germânicas Wodan e Tîwaz, assumindo algumas de suas qualidades no final do período pagão.

Senhor do Valhala, Óðinn surge não apenas como um doador de armas e conhecimentos bélicos, mas como aquele que decide quem serão os vencedores. Conta a lenda que Mimir, o mais sábio dos Æsirs e guardião de uma das fontes sob a árvore do mundo, no território dos gigantes, teria permitido que Óðinn bebesse da fonte do conhecimento e assim adquirisse conhecimentos mânticos. Mas com uma condição: Óðinn deveria sacrificar um de seus olhos em pagamento, e por isso ele é por vezes descrito usando um chapéu pendente sobre o olho que lhe falta.

Sentado em Hliðskjálf, seu trono em Valhala, Óðinn observa o mundo todo. Sob os seus ombros estão pousados dois corvos; Munin (entendimento/memória) e Hugin (razão) constantemente a sussurrar-lhe o que viram em suas viagens de observação pelo mundo. Montado em seu cavalo de oito patas - Sleipnir - capaz de cavalgar no espaço, com sua armadura e elmo de ouro, Óðinn cavalga para a guerra.

Venerado principalmente na Noruega e Suécia, o filho de Óðinn e deus do trovão, Pórr, é outra importante divindade do paganismo nórdico. Divindade rústica, capaz de devorar em um único banquete um boi inteiro, oito salmões e três tonéis de hidromel, Pórr também é conhecido como "o senhor dos bodes" por ser descrito atravessando os ares em uma biga puxada por dois bodes.

Diferente de Óðinn, venerado majoritariamente pela aristocracia guerreira, Pórr é considerado amigo fiel dos homens e seu culto está relacionado à família, à comunidade, à massa popular. De enorme estatura mas de aparência rústica, assemelhase mesmo a um camponês nórdico típico. Controlador do raio, do trovão, das chuvas, das estações do ano, Pórr é descrito como um deus de grande vitalidade e apetite, de barba vermelha e olhos faiscantes, brandindo seu inseparável martelo Mjölnir, especialmente confeccionado pelos anões para defender os deuses dos gigantes. Além 
do martelo, Pórr também possui um cinto mágico chamado Megingiardur, que, quando posto em ação, multiplica a força do deus, tornando-o ainda mais poderoso. Pórr era tão popular entre os Vikings que estes chamavam a si mesmos de "o povo de Pórr". 


\title{
CAPÍTULO III: RICHARD WAGNER E O MITO DA NOVA HUMANIDADE
}

\begin{abstract}
"Bayreuth é a consumação do mistério ariano (...) A essência da arte ocidental revela-se em Wagner: a saber, que a alma nórdica não é contemplativa, que ela não se perde na psicologia individual, que ela aspira viver segundo as leis cósmicas da alma e formá-las espiritualmente, arquitetonicamete"
\end{abstract}

(Alfred Rosenberg, ideólogo nazista)

“(...) aquele que atribui essa decadência do espirito publico unicamente à degeneração do nosso sangue, causada não somente pelo abandono da alimentação natural do homem, como muito mais pela mistura degenerante do sangue heróico das raças mais nobres com o de antigos canibais que se tornaram, hoje, os mercantes experimentados de nosa sociedade, pode muito bem ter razão"

(Richard Wagner)

\section{Considerações biográficas}

Richard Wagner nasceu em 22 de maio de 1813 em Leipzig. Apesar de algumas controvérsias históricas que supõem que ele seria filho do ator e pintor Ludwig Geyer ${ }^{1}$, um amigo da família, oficialmente seu pai seria o escrivão da diretoria da polícia, Carl Friedrich Wilhelm Wagner, que morreu quando Wagner ainda era bebê, vitimado pelo surto de febre tifóide que assolou a Alemanha após 1814. Sua mãe casou-se novamente em 1815, com Geyer, que assumiu a numerosa família da qual Wagner era o nono filho.

Nascido em uma família onde boa parte de seus irmãos e irmãs seguiram a carreira artística, e sob a influência de seu padrasto, que era ator e também pintor, não causa estranheza o interesse precoce do menino pela literatura e pela música, apesar dos desejos de Geyer de que ele fosse pintor. Após um interesse inicial pela poesia, sobretudo os trágicos gregos, sua irmã Rosália, que se empregara por um tempo em Leipzig, desenvolve nele o gosto pela música. Clara, sua outra irmã, era cantora lírica.

\footnotetext{
${ }^{1}$ Sobre isso, ver Millington, B. Wagner, um compêndio, p. 110.
} 
Entretanto, é mesmo após o contato com as obras de Beethoven e Mozart que ele descobre sua verdadeira vocação. Tenta tomar aulas de música mas não dispõe de recursos para isso, até que no verão de 1829, ao ser deixado sozinho em Leipzig, consegue obter aulas de harmonia a um preço muito modesto com o músico da orquestra da cidade - Gottlies Müller - mas sem muitos progressos.

Tendo se envolvido com a política nos tempos da faculdade, isso por volta de 1830, Wagner deixa a música um pouco de lado, submerso em seu sonho românico de escrever a "música política". Esse sonho de juventude voltará a dar frutos no futuro mas, no estreito âmbito da realidade cotidiana, ele retoma as aulas de música com Theodor Weilig. Diferente do que acontecera com Muller, Wagner consegue progredir em seu aprendizado sob os ensinamentos de Weilig.

Logo cedo, e apesar do início frustrado na composição do libreto de As núpcias (que ele rasga aconselhado por Rosália), Wagner decide ser seu próprio libretista e compõe, em Wurzburg, As fadas, uma ópera romântica em três atos baseada no conto La donna serpente, do dramaturgo veneziano do século XVIII Carlo Gozzi. Prenhe de influências mitológicas, a ópera conta a história de Arindal, príncipe de Tramond, que é transportado durante uma caçada para o reino mágico de Ada, uma jovem meio fada e meio mortal. Ada concorda em se casar com Arindal desde que ele evite, por oito anos, perguntar-lhe sobre sua origem. O leitmotiv da ópera, assim como será com Lohengrin, é o tema da "pergunta proibida", bem como o amor de um mortal por uma fada, tema que remontava à Idade Média e já bem estabelecido no imaginário romântico popular. $\mathrm{O}$ tema da redenção também se mostra caro a Wagner desde essa primeira ópera.

Agora nomeado, um tanto a contragosto, chefe da orquestra do teatro de Magdeburg, ele conhece Minna Planer, que será sua esposa em um casamento infeliz por mais de uma década. Minna, aponta um de seus biógrafos,

\footnotetext{
"foi para ele, em certos momentos, um encargo muito pesado. Não tinha espírito, conservava-se rasteira quando o gênio elevava para longe deste mundo o compositor inspirado; tinha exigências que ele não compreendia, asperezas que o magoavam muito. Suportou, porém, ao seu lado, longos períodos de miséria; foi a companheira dos maus dias e soube pela sua economia, por suas qualidades domésticas, permitir uma vida que, sem ela, seria seguramente mais precária se não a pior vida de boemia. Foi infeliz junto
} 
dele e ele não o foi menos a seu lado, porque mutuamente se fizeram sofrer; nem sempre ele fez papel bonito e ela nem sempre foi perfeita"2.

Parte do horror de Wagner ao casamento como instituição burguesa usualmente baseada na falta de amor e no direito de propriedade podem encontrar aí a sua justificação. O tema, que converter-se-á praticamente em uma obsessão, veremos surgir no esboço de 1849 de sua obra Jesus von Nazareth e também no Anel; basta lembrarmos do inflamado diálogo entre Wotan e Fricca acerca do relacionamento ilícito dos irmãos Siegmund e Sieglinde.

Agora casado, ele deixa Königsberg e vai para Riga, em 1837, para ser maestro em um novo teatro. Se A noviça de Palermo (A proibição de amar) não tivera o menor êxito quando executada, uma única vez, em Magdeburg (29 de março de 1836), o período de trabalho em Rienzi foram tempos de dissabores ainda maiores que o fracasso em Magdeburg. Ele é obrigado, por conta de intrigas envolvendo o seu nome e o de Minna, a abandonar Riga em 1839. Neste ínterim adoece de febre tifóide e é abandonado duas vezes por Minna.

Vencida essa primeira tormenta, ele resolve se mudar para Paris, na companhia de Minna, passando inicialmente pela Inglaterra. Mesmo sobre a proteção de Meyerbeer nada dá certo em Paris e Wagner precisa viver de pequenos trabalhos para escapar da miséria. Mas consegue tempo, finalmente, para concluir Rienzi. Sob a pressão do inverno rigoroso de 1840-1841 e com a penúria sempre à espreita, ele é obrigado a negociar por 500 francos os direitos autorais sobre o libreto de $O$ navio fantasma, que ele escrevera durante a viagem para Paris. Com o dinheiro consegue alugar um pequeno apartamento e, depois de conseguir um piano, começa a compor a música para $O$ navio fantasma. Novamente os ventos da miséria lhe batem à porta.

Em 1842 voltam a Dresden, após notícias de que Wagner poderia executar lá suas duas últimas obras. Visita sua mãe em Leipzig mas, ao chegar a Berlim, descobre que as promessas que o fizeram retornar à Alemanha estavam longe de se concretizar. Com a ajuda financeira do cunhado Brockhaus, consegue sobreviver até a montagem de Rienzi que será encenada em Dresden, e enquanto aguarda começa a escrever o Tannhäuser, cujo título provisório ainda era Venusberg.

Finalmente, Rienzi estréia em 20 de outubro de 1842 com uma apresentação de mais de seis horas de duração e mesmo assim é um sucesso. Animado, Wagner decide

\footnotetext{
${ }^{2}$ Dumesnil, R. Vidas de Wagner e Massenet, p. 19.
} 
montar $O$ navio fantasma para o ano seguinte (e é nesse ínterim que ele conhecerá o compositor Franz Liszt, um amigo fiel para toda a vida), mas o sucesso esperado não se concretiza. Mesmo assim, Wagner consegue, ainda por conta do sucesso de Rienzi, a vaga de mestre de capela da Corte de Saxe, que ele aceita não sem alguma hesitação. $O$ trabalho, porém, se não era o ideal, assegurará ao compositor a tranqüilidade que ele não tivera até então.

Tannhäuser, agora concluída, também não faz sucesso. Enquanto isso, caminhava a produção de Lohengrin, que será concluída quando Wagner, sob a influência da excitação causada pela leitura dos Eddas e do Nibelungen, já vislumbra no horizonte o caminho para revolucionar a ópera e o teatro modernos. O primeiro passo foi a redação do poema $A$ morte de Siegfried, que ele incorporará à sua famosa Tetralogia do Anel, sobre a história dos Nibelungos.

Nessa época, ainda motivado pelo clima de agitação política, é que Wagner conhece Bakunin, cujas idéias revolucionárias lhe impressionam. Em parte por conta disso, quando estouram motins em Dresden, em 1849, Wagner estava comprometido com as agitações e foge para Weimar, onde também não estará seguro. Wagner precisou exilar-se em Paris por 12 anos. E foi por essa época, mais especificamente em 1850, ainda sob a influência da fracassada ação revolucionária de 1849 - culminando com a vitória da contra-revolução - que Wagner tornou público seu anti-semitismo com a elaboração de um panfleto anti-judaico. Concluído o relacionamento com Minna, que estava abandonada e sem recursos em Dresden, Wagner, que outrora ficaria abatido, desta vez não se importa com o novo rompimento: sua atenção já estava voltada para Jessie Laussot, casada e, como ele, infeliz no casamento. Mas a vida amorosa de Wagner não é assim tão simples: ele volta a se reconciliar com Minna, mas não antes de tentar fugir para a Grécia ou Ásia Menor com Jessie Laussot, quando o marido desta descobre tudo e frustra seus planos.

Enquanto isso, Liszt encarrega-se de mandar executar, em Weimar, Lohengrin, que alcança um considerável sucesso, capaz mesmo de tornar possível para Wagner viver de sua obra. A felicidade da consagração finalmente lhe sorri. Estando em Zurique ele trabalha sobre os poemas que darão origem à Tetralogia do Anel, trabalho este que será interrompido novamente pela excitação de um novo amor proibido: Matilde Wesendock, também casada. O romance dura pouco (graças à intervenção de Minna), mas sublima-se em seu Tristão e Isolda. Tem início mais uma fase negra de fracasso na vida profissional de Wagner, que não consegue convencer nem o público e nem os 
críticos com a sua música. O desespero dura até 1846, quando o príncipe Luís II da Baviera lhe oferece sua proteção, e junto com isso muitos recursos em dinheiro, que logo despertarão o ciúme na corte. Apesar de um desentendimento entre ele e o príncipe, em parte causado por intrigas, os dois continuarão amigos.

Paralelamente a isso, Wagner, ainda preso a Minna, apaixona-se agora por Cosima von Bullow, outra mulher casada e, desta vez, com uma complicação a mais: ela era a segunda filha de seu amigo Liszt. O romance tem início no final de 1863, e será a última aventura amorosa de Wagner, desta vez com sucesso. Já que, como afirmou acidamente um de seus biógrafos, "Minna esta vez não está presente para atrapalhar os amores de Wagner: tivera a boa idéia de morrer em 1865"3. Passado o constrangimento de Liszt e o escândalo causado pelo seu relacionamento com Cosima, que lhe valeu uma visita do próprio rei Ludwig em busca de explicações, Wagner esposa Cosima em 1870, com quem já tinha, a essa época, três filhos.

Dois anos antes, em Leipzig, Wagner conhece Nietzsche, que será seu admirador. Esse relacionamento entrará para a história não tanto por seu início, mas por seu término, quando Nietzsche, que chegara a considerar o amigo Wagner como um compositor revolucionário, o maior de seu tempo, decepciona-se com o retrocesso de Wagner ao cristianismo e à Igreja ${ }^{4}$. Retornaremos a esse ponto, à relação Nietzsche/Wagner em uma outra oportunidade.

Gozando de um merecido prestígio, Wagner consegue recursos para construir, em Bayreuth, um teatro de festivais, onde pudesse encenar suas grandes óperas. $\mathrm{O}$ empreendimento, que quase levou Wagner à falência (novamente), só foi possível graças à intervenção do rei da Baviera, que lhe fornece os recursos financeiros necessários para a conclusão da obra. Wagner sonhava com isso desde 1849, com a criação de um teatro subsidiado pelo estado e destinado à "arte do futuro". A escolha de Bayreuth, como nota Stewart Spencer, também possuía uma motivação política:

\footnotetext{
"Bayreuth não apenas estava sob domínio bávaro, permitindo com isso que Wagner continuasse a servir-se do tesouro de Ludwig, como seus laços históricos com a Prússia sugeriam uma démarche na direção de Bismarck, cuja causa militarista o compositor agora abraçava. Em 1874, Wagner chegou ao ponto de se oferecer para encenar o Anel
}

\footnotetext{
${ }^{3}$ Dumesnil, R. Vidas de Wagner e Massenet, p. 40. O fragmento é delicioso, mas a data não confere. Minna faleceu em Dresden, em 25 de janeiro de 1866.

${ }^{4}$ Sobre isso, ver: Macedo, I. Nietzsche, Bayreuth e a época trágica dos gregos. Kriterion, Belo Horizonte, $\mathrm{n}^{\mathrm{o}} 112$, dez/2005, p. 284.
} 
em Bayreuth como uma comemoração qüinqüenal da vitória da Alemanha sobre a França".

Alguns meses depois, Wagner verá sua obra mais importante, o Anel, representada no Festpielhaus de Bayreuth. Em 13 de fevereiro de 1883, ainda cheio de planos e com muito vigor físico, após uma violenta discussão com Cosima (conta-se que por causa de Carrie Pringle, que representava uma das ninfas do Reno na Tetralogia), Wagner sofre um ataque cardíaco fulminante e morre horas depois.

\section{A tetralogia do anel}

Por volta do início do século XIX, o poema épico medieval Nibelungenlied já gozava de uma crescente popularidade na Alemanha, popularidade essa que atingiria seu pico na década de 1840, quando a saga do nibelungo se converteu em um símbolo importante na defesa da unificação alemã.

A esse tempo, em 1845, Franz Brendel, editor do periódico de música Neue Zeitschrift Musik, aponta que aquele compositor que produzisse uma ópera sobre os nibelungos certamente tornar-se-ia a personalidade de sua época. Em 1869, Richard Wagner apresentaria em Munique sua ópera sobre os nibelungos. Ele não chegou a ser o primeiro a dar uma forma operística ao poema, mas a sua tetralogia sobre o tema decerto lhe conferiu a notoriedade a que aludira Franz Brendel.

Na composição da obra, Wagner buscou inspiração na Edda poética, na Völsung Saga, na Edda em prosa de Snorri Sturluson (fontes islandesas), em Das Nibelungenlied - um poema épico escrito por volta de 1200 em alemão medieval - e em Thidreks Saga at Bern, uma narrativa escrita em norueguês antigo (prosa) em torno de 1260-70. As influências do teatro grego também são dignas de nota.

Apesar da primeira apresentação ter lugar apenas em 22 de setembro de 1869, o esboço em prosa remonta a 1848. A obra, tendo em consideração algumas interrupções, ocupou Wagner por 26 anos: de 1848 (primeiro esboço em prosa) até 1874 (retoques finais na última parte). Concebido originalmente como um só drama, a ópera expandiuse em uma longa tetralogia que ocupava quatro noites, totalizando mais de 14 horas de espetáculo.

\footnotetext{
${ }^{5}$ Spencer, S. Bayreuth e a idéia de um teatro de festivais, in: Millington, B. Wagner: um compêndio, p. 191.
} 


\section{O ouro do Reno (Das Rheingold)}

Personagens: Deuses (Wotan/Odin, Donner/Thor, Froh, Loge/Loki); Nibelungos (Alberich, Mime); Gigantes (Fasolt, Fafner); Deusas (Ficka, Freia, Erda); Ninfas do Reno (Woglinde, Wellgunde, Flosshilde).

\section{Prelúdio e cena 1}

Nas águas do rio Reno vemos três irmãs ondinas, ninfas do Reno ${ }^{6}$. Duas delas (Wellgunde e Woglinde) divertem-se brincando de provocarem-se e perseguirem umas às outras. A terceira, Flosshilde, censura as irmãs por descuidarem, enquanto brincam, da vigilância do "ouro adormecido" do qual são as guardiãs. Enquanto isso, um anão, o nibelungo Alberich, sem ser notado, observa-as encantado. Em seguida ele chama a atenção das jovens ninfas elogiando-lhes. A princípio, assustadas, as ninfas fogem da figura horrenda do anão, para logo em seguida o medo dar lugar ao riso enquanto elas se alternam em caçoar dele. As ninfas encorajam o anão em suas investidas apaixonadas para depois fugirem dele, zombando de sua corcunda, de sua aparência de sapo e de seu corpo peludo.

Exausto e furioso, o nibelungo desiste das investidas ao notar uma luz brilhante no interior das águas, crescendo até tomar todo o ambiente. As ninfas passam a saudar aquela irradiação brilhante repetindo: "Ouro do Reno! Ouro do Reno! Luminoso júbilo!". Tomado de curiosidade e ainda hipnotizado pelo brilho fulgurante, Alberich pergunta às ninfas o que representa aquele brilho. As jovens não acreditam que alguém desconheça o "ouro do Reno". Alberich faz pouco caso da devoção das ninfas ao precioso ouro, então Woglinde e Wellgunde comentam de forma imprudente que o anão não faria pouco caso se soubesse da magia daquele ouro: quem forjasse um anel com ele dominaria o mundo. Flosshilde adverte suas irmãs que sua imprudência em alertar Alberich do poder do tesouro que elas guardam poderia colocá-las em risco. Suas irmãs riem e fazem pouco caso da advertência. Quem quer que se dispusesse a apossar-se do Ouro teria que "renunciar ao amor", algo a que um anão tão lascivo e apaixonado quanto Alberich não estaria disposto a abdicar. Mas enquanto elas voltam a caçoar dele, o anão escala o rochedo rapidamente e, tomando o Ouro para si, em seguida amaldiçoa o amor.

\footnotetext{
${ }^{6}$ Espécie de sereias, sem a famosa cauda de peixe.
} 
A luminosidade dá lugar à escuridão enquanto as ondinas gritam por socorro.

\section{Cena 2}

Wotan (Odin), o senhor dos deuses, dorme sobre um amplo terreno florido nas montanhas ao lado de sua esposa Fricka, a deusa do matrimônio. Atrás deles vemos a imponente fortaleza. Wotan, que sonhava com o castelo que estava sendo construído, põe-se a falar enquanto dorme sobre "a beatífica mansão". Fricka, irritada, sacode-o para que ele acorde de seus sonhos. Ao despertar, Wotan contempla a magnífica construção, mas Fricka o lembra da promessa feita em troca do serviço dos gigantes na construção do castelo: entregar-lhes Freia, a deusa da juventude, irmã de Fricka.

Wotan diz à esposa que ela não deve se preocupar com isso, mas Fricka o recrimina dizendo que os homens escondem coisas das mulheres para melhor cometerem seus desatinos e afirma que se tivesse sido avisada do acordo ela o teria impedido. Os homens, acusa, fazem de tudo por causa da avidez que têm pelo poder. Wotan argumenta que tal avidez estaria presente nela, que fôra quem sugerira a construção do castelo. Mas Fricka, expressando bem sua inclinação caseira e familiar, diz-lhe que fizera tal sugestão desejando a fidelidade de Wotan, na ilusão de que um lar aconchegante talvez o fizesse sossegar dentro de casa, e conclui - após uma réplica irônica do marido, que lhe lembra que sendo ele um deus poderia dispor do mundo mesmo à distância - que ele não valoriza as mulheres. Wotan, agora tomado de seriedade, responde que para cortejá-la precisou penhorar um de seus olhos ${ }^{7}$. E acrescenta que nunca pretendera cumprir o acordo de entregar Freia.

Neste momento, surge Freia, aflita, pedindo ajuda à irmã e ao cunhado, posto que Fasolt aproximava-se para buscar o seu pagamento. Wotan, muito calmo, pergunta por Loge (o deus do fogo) e, diante do espanto de Freia, que não confia no ardiloso Loge, Wotan argumenta que nesse caso não adianta apenas a força bruta; ele necessita da astúcia de Loge.

Entram em cena Fasolt e Fafner, os irmãos gigantes, vestidos de peles cruas e portando suas clavas para cobrar o acordo. Fasolt é quem fala. Cinicamente, Wotan declara: "Dizei vosso preço". Fasolt lembra-lhe que o preço já havia sido estipulado: Freia. Wotan exige que os gigantes peçam outra coisa em pagamento. Fasolt reage: “o que? Tu, o próprio Wotan, estás pensando em trair um contrato?". A surpresa e

\footnotetext{
${ }^{7}$ Ao que parece, essa dívida não foi paga, pois Wotan já dera em pagamento um dos olhos em outra ocasião. Se tivesse de arcar com mais essa dívida, ficaria cego.
} 
indignação de Fasolt são perfeitamente justificadas: Wotan é um legislador e deveria ele, mais que todos, saber honrar um acordo. Mas Wotan não se incomoda com as admoestações do gigante e, abusando do cinismo, pergunta-lhes como puderam levar a sério um acordo "feito por pura brincadeira". Fasolt reclama magoado, mas com perfeito discernimento da situação: “Zombas de nós, não é? Que injustiça! Os luminosos deuses servem-se do trabalho dos rudes, prometendo-lhes uma bela e terna mulher, e agora invalidas o contrato?".

Fafner, muito mais prático, pouco se importa com a beleza de Freia e repreende o irmão, instando-o a raptá-la de uma vez, e diz que a única serventia de Freia é que sem ela os deuses ver-se-iam enfraquecidos sem as maçãs douradas por ela cultivadas ${ }^{8}$. Enquanto isso a tensão aumenta com a demora de Loge em surgir com uma solução para o impasse, até que os gigantes fazem menção de levar Freia a força. Nisso os irmãos de Fricka e Freia, Donner (Thor ${ }^{9}$ ) e Froh surgem e impedem o rapto. A tensão só aumenta até que finalmente surge Loge - o deus do fogo, mas jocosamente considerado o "deus da mentira".

Pressionado por Wotan, que lhe cobra uma solução para o problema, ele responde que procurou em todo o lugar mas não encontrou uma solução. Diz que correu o mundo buscando um substituto para Freia que satisfizesse os gigantes, mas sem sucesso, porque ninguém soube apontar algo mais atrativo para o homem que "o amor e o prazer que a mulher pode proporcionar". Porém, insinua que apenas uma pessoa renunciara ao amor e à mulher, em troca do poder de um "ouro reluzente". Loge está se referindo a Alberich, o anão nibelungo que roubara o ouro guardado pelas ninfas do Reno. Wotan fica muito interessado na história e os gigantes começam a considerar a hipótese de aceitar o ouro mágico como pagamento, abrindo mão de Freia. Fafner acaba conseguindo convencer Fasolt a aceitar o ouro no lugar da jovem, por mais que este estivesse mais interessado no amor da deusa que no ouro das ninfas. Assim sendo, Fafner exige que Wotan tome o ouro de Alberich e entregue-lhes como pagamento, mas, como garantia, levará Freia consigo até que lhes seja entregue o ouro. Eles partem com a deusa e logo em seguida os deuses começam a definhar. Todos menos Loge, que

\footnotetext{
${ }^{8}$ Freia cultiva maçãs mágicas que fornece aos deuses, mantendo assim suas juventudes. Por isso ela é a deusa da juventude. Ao que parece, os deuses (à exceção de Loge) não estavam cientes de que a sua juventude devia-se às referidas maçãs.

${ }^{9}$ Convém prestarmos atenção a essa apagada aparição de Donner/Thor, já que o deus do trovão raramente surge na obra de Wagner.
} 
na verdade é um semi-deus, e por isso menos dependente das maçãs da juventude de Freia. Wotan e Loge partem em busca do ouro.

\section{Cena 3}

Como desde o roubo do Ouro do Reno Alberich conseguira impor sua tirania aos nibelungos submetendo-os através do poder do anel mágico forjado a partir do ouro das ondinas, vemos, no fundo de Nibelheim, o país dos nibelungos, Alberich torturando seu irmão Mime e exigindo que este lhe entregue Tarnhelm, o elmo mágico cujo poder é o de tornar invisível todos aqueles que o usem, além de poder transformar seu usuário em qualquer coisa que este deseje. Alberich testa a eficácia do elmo recém forjado, tornando-se invisível e dando uma surra no irmão.

Quando Wotan e Loge chegam em Nibelheim, encontram Mime caído e gemendo após a surra de Alberich. Sem saber a identidade dos dois estranhos, Mime se põe a responder às perguntas de Loge acerca da situação dos nibelungos. Logo em seguida chega Alberich brandindo o anel mágico e ameaçando novamente a todos: "tremei e obedecei prontamente ao senhor do anel!".

Nisto, Loge, fazendo-se reconhecer, passa a demonstrar toda a sua astúcia, elogiando o anão e fazendo com que Alberich revele os seus planos. Ele pretende, com o poder do anel, conseguido através da renúncia ao amor, subjugar todos os deuses. Em meio a bravatas, Alberich mostra a Loge o Tarnhelm e o astuto deus do fogo, demonstrando incredulidade, exige uma demonstração do poder do elmo mágico. $\mathrm{O}$ anão transforma-se em um dragão e Loge finge estar assustado. Em seguida perguntalhe se Alberich conseguiria, com a ajuda do elmo, transformar-se em algo muito pequeno, sugerindo por fim que tal proeza seria muito difícil de conseguir. A provocação fere a vaidade do anão e ele manda Loge escolher o tamanho que quisesse para a demonstração. O deus do fogo sugere algo com a dimensão do corpo de um sapo. A astúcia de Loge dera resultado: metamorfoseado em sapo, Alberich é imobilizado pelo pé de Wotan enquanto Loge lhe retira o elmo. Ao voltar a sua forma normal, o anão é amarrado e levado aos arredores do castelo de Wotan na superfície.

\section{Cena 4}

Loge e Wotan zombam agora das pretensões do anão de dominar o mundo e exigem o ouro roubado em troca de sua liberdade. Sem escolha, Alberich usa o anel para chamar os nibelungos, que lhe trazem o ouro. Mesmo descontente, ele sabe que 
continuando com a posse do anel poderá utilizá-lo para criar mais riquezas. Terminado o transporte do tesouro das ninfas, Alberich exige o elmo de volta e pede para ser libertado. Loge lhe diz que o elmo faz parte do preço e lança-o sobre a pilha de ouro. Mesmo indignado, o anão pondera que Mime poderá forjar um novo elmo para ele, mas suas ilusões se desfazem quando Wotan exige o anel em seu dedo. Desesperado, o anão suplica: "Minha vida, mas não o anel!". Impassível, Wotan lembra-lhe que o anel fôra forjado a partir do ouro roubado, e em seguida arranca-lhe o anel a força, mas antes disso Alberich aponta a hipocrisia de Wotan lembrando-lhe que se o deus soubesse forjar o ouro em um anel também o teria roubado, pecando assim contra tudo o que ele fôra, é e será. Após ter o anel arrancado violentamente de seu dedo, Alberich amaldiçoa-o: "Seu ouro me conferiu poder ilimitado, que agora sua magia traga a morte aquele que o possua".

Encontrando os gigantes, Wotan exige a devolução de Freia e aponta o resgate. Fasolt, dirigindo-se ao deus, diz-lhe o quanto será penoso renunciar a Freia e que por isso, para que possa esquecê-la, o ouro deverá ser empilhado em frente à jovem até que ela não possa mais ser vista por detrás do monte de ouro. Aqui e ali surgem brechas de onde ainda é possível avistar Freia, e sempre que isto acontece os gigantes exigem mais uma peça de ouro para tapar a fenda. Como os cabelos da deusa ainda podem ser vistos, Fafner exige o Tarnhelm para ocultá-los. Depois de um tempo Loge declara o fim do trabalho. Mas Fasolt, apaixonado, percebe que ainda vê o "raiar dos olhos" de sua amada Freia e afirma que não a deixará enquanto ainda a veja. Fafner exige o fechamento da lacuna, mas Loge argumenta que tudo já fôra entregue, mas Fafner lembra ao deus do fogo que na mão de Wotan ainda reluz um anel dourado.

Wotan reage dizendo que não entregará de forma alguma o anel, apesar da súplica dos deuses ali reunidos. Neste momento, surge das profundezas da terra, a meio corpo, Erda. A misteriosa personagem é a "deusa da terra", uma mulher primordial. Os deuses parecem não conhecê-la, tanto que Wotan lhe pergunta quem ela é. A grande deusa lhe diz ser a "mulher primordial do Eterno Mundo", mãe das três Nornas que à noite aconselham Wotan, mas que em vista de um grande perigo decidiu vir pessoalmente alertá-lo: "Um dia sombrio se abaterá sobre os deuses. Eu te aconselho: renuncia ao anel!”. Em seguida, a misteriosa deusa submerge nas profundezas da terra, apesar das súplicas de Wotan para que fique e conceda-lhe mais ensinamentos. Impressionado com a aparição, Wotan entrega o anel. 
Tão logo Freia é libertada, os dois gigantes começam a discutir pela partilha do ouro, enquanto os deuses partem. Fasolt quer ficar com o anel, pois este lhe lembra os olhos de Freia, mas Fafner não quer ceder. Os dois começam a lutar. Fasolt toma o anel a força e nisto Fafner lhe atinge com sua clava, matando o irmão. Os deuses que a certa distância observavam a cena ficam comovidos, e Wotan percebe que a maldição de Alberich começava a surtir efeito.

Os deuses seguem juntos ao castelo recém-construído, que só agora Wotan dera um nome ao falar a Fricka: "Vem, mulher, viver comigo no Walhalla". Enquanto isso eles ouvem o lamento das ondinas pelo ouro perdido e não lhes dão importância.

\section{II - A Valquíria (Die Walküre)}

Personagens: Siegmund, Hunding, Wotan, Sieglinde, Brünnhilde, Fricka, as Valquírias (Gerhilde, Ortlinde, Waltraute, Schwertleite, Helwige, Siegrune, Grimgerde, Rossweisse).

\section{Prelúdio o ato I}

Vemos o interior da cabana de Hunding, de onde sai uma grande árvore cujos ramos atingem o exterior através de aberturas no teto. Uma forte tempestade castiga a cabana quando entra Siegmund procurando abrigo e desmaia exausto sobre uma pele de urso. O estranho é encontrado por Sieglinde, esposa de Hunding. Ao despertar, Siegmund pede-lhe água e mostra-se fascinado pelo rosto de Sieglinde. Em seguida, conta-lhe que foi ferido em uma luta, mas que é forte e já estaria refeito. Com receio de trazer-lhe alguma má sorte, ele se dispõe a sair, mas cede ao pedido de Sieglinde para que fique.

Ao chegar em casa, Hunding oferece, um tanto insatisfeito, sua hospitalidade ao estranho, que lhe conta sua história. Começa dizendo, por insistência dos donos da casa em saber seu nome, que estes podem chamá-lo de Wehwalt (o desafortunado). Conta-lhe então que ao retornar de uma caçada com seu pai, Wolfe, encontrara sua casa incendiada, sua mãe morta e sua irmã gêmea desaparecida. $\mathrm{O}$ ataque fôra obra do povo Neindinge (invejoso). Ele e o pai decidiram então viver na floresta (Hunding afirma já ter escutado falar da corajosa dupla) enfrentando diversos inimigos. Perseguidos pelos Neindinge, ele se perde do pai, levando a partir de então uma vida sem rumo. 
Suas armas haviam sido perdidas na tentativa de resgatar uma jovem do destino de casar-se com um homem a quem não amava. Na luta ele conseguira matar todos os irmãos da jovem, mas os outros parentes partiram em seu encalço. Suas armas quebraram no combate e ele não conseguira proteger a jovem, que morrera diante de seus olhos. O final de sua fuga fôra a casa de Hunding. Para o azar de Siegmund, após concluir a sua narrativa, Hunding lhe revela ser um dos parentes da família da jovem que estão perseguindo. Acrescenta que nesta noite ele será seu hóspede, mas no dia seguinte lutarão.

Sieglinde prepara uma bebida para o marido e põe nela uma droga. Ao abandonar o recinto, lança um olhar para o forasteiro indicando-lhe um determinado ponto na árvore que cresce no meio da cabana. Só depois Siegmund se dá conta do que se trata: cravada no tronco da árvore havia uma espada que lhe seria de grande auxílio na luta do dia seguinte. Um dia seu pai lhe prometera que quando ele estivesse em grande necessidade, encontraria uma espada para ajudá-lo em sua aflição.

Sieglinde retorna e conta-lhe que fôra raptada e obrigada a casar-se com Hunding. Durante a festa de casamento, um forasteiro com um chapéu cobrindo um dos olhos $^{10}$ entrara na cabana e cravara sua espada na árvore que crescia em seu centro, desafiando a todos a tirá-la dali. Aquele que conseguisse retirar a espada poderia ficar com ela. Nenhum dos presentes foi capaz de retirá-la do tronco. Sieglinde deduz que a arma estaria destinada a ele, o forasteiro. Este a abraça com paixão e em seguida ambos declaram seu amor. Ele admite não ser mais Wehwalt (desafortunado). Sabendo que o nome do seu pai era na verdade Wälse, e não Wolf (lobo), Sieglinde chama-o de Wälsung e em seguida de Siegmund ("guardião da vitória"). Ele consegue retirar a espada da árvore, a que chamará de Notung (“indispensável”).

\section{Ato II}

Enquanto isso, no cimo de uma montanha, Wotan instrui sua filha Brünnhilde, uma Valquíria, a ajudar Siegmund na contenda com Hunding, garantindo-lhe a vitória. Nisso chega Fricka furiosa e exige que Wotan puna o casal de adúlteros ${ }^{11}$. Wotan argumenta não ter nenhum respeito por uma união sem amor como aquela que unia Sieglinde a Hunding. Fricka então faz notar a relação incestuosa dos amantes e lança

\footnotetext{
${ }^{10}$ Lembremo-nos que Wotan, por haver perdido um dos olhos, usara o chapéu encobrindo o olho que faltava.

${ }^{11}$ Lembremos que ela é a "deusa do matrimônio".
} 
sobre Wotan acusações acerca de sua infidelidade que gerara filhos aqui e ali, inclusive o casal em questão ${ }^{12}$.

Wotan, que não quer revogar a ordem dada à Valquíria, e instando-a a dar a vitória a Hunding, afirma que Siegmund é um herói independente que chegou a ser o que é sem o auxílio dos deuses, e que estaria, portanto, livre da lei dos deuses. Fricka discorda e lhe diz que os heróis nada são sem o auxílio dos deuses. Tem lugar aí uma interessante discussão acerca da dependência ou independência dos heróis, com Wotan argumentando em defesa de Siegmund dizendo que não o ajudará em nada. Fricka então arremata dizendo que isso não é verdade, tanto que Wotan plantara uma espada mágica na árvore para auxiliar seu filho. Não havia argumentos contra isso, e Fricka exige que Wotan abandone Siegmund à sua própria sorte. Desolado, ele chama a Valquíria de volta e retifica suas ordens.

Quando ficam sozinhos, Wotan e Brünnhilde, o deus conta à filha, após alguma hesitação, que, quando os prazeres do amor jovem se foram, ele passou a desejar o poder. E ele conseguiu mesmo dominar o mundo, mas ficou prisioneiro dos tratados e acordos. Narra-lhe, então, a história de como obtivera o anel mágico forjado com o ouro roubado das ninfas para quitar sua dívida com os gigantes e de como ficara encantado com a sabedoria de Erda, tanto que em seguida foi procurá-la nas profundezas da terra para tomá-la como amante e gerar as Valquírias ${ }^{13}$. O plano de Wotan era reverter a catástrofe, predita por Erda, que se abateria sobre os deuses. Por isso ele incumbira as Valquírias de conduzir os mais valorosos combatentes para o Wallhalla, onde ali ele formaria um exército para defender os deuses.

Wallhalla estava bem guarnecida, mas o anel permanecia em poder dos gigantes e Wotan não poderia usar da força para recuperá-lo por estar preso ao acordo firmado e já quitado com os gigantes. Para isso ele precisaria de um herói independente de sua influência para recuperá-lo: Siegmund. O casal gerado por ele, Wotan, para redimir o mundo através da bravura de Siegmund, como lhe lembrara Fricka, havia falhado. Siegmund, efetivamente, não era independente de sua proteção: Wotan lhe proporcionara mesmo a espada Notung, e tivera que dar razão a Fricka. Brünnhilde agora precisará defender Hunding. Ela tenta recusar a ordem mas Wotan a ameaça com severos castigos caso sua ordem não seja cumprida.

\footnotetext{
${ }^{12}$ Siegmund e Sieglinde são filhos de Wotan com uma mortal.

${ }^{13}$ Aqui jaz uma confusão. Apenas uma das Valquírias fôra gerada com Erda: Brünnhilde.
} 
Enquanto isso Siegmund e Sieglinde prosseguem em sua fuga chegando ao cume de uma montanha. Sieglinde, em delírio, imagina os cães de Hunding devorando Siegmund e desmaia. É aí então que Brünnhilde aparece para Siegmund anunciando a sua morte: "Sou aquela a quem logo seguirás". Siegmund não quer seguir para o Wallhalla sem sua irmã e amante, ameaçando matá-la para que eles não se separem. Brünnhilde, tocada, promete protegê-lo na luta, desrespeitando Wotan, e realmente o faz. Mas Wotan, preso pela promessa, surge e é obrigado a intervir, quebrando a espada de Siegmund com sua lança. Desarmado, ele é abatido por Hunding, mas Wotan o mata em seguida.

Brünnhilde chama Sieglinde e montada em seu cavalo foge com ela. Wotan, furioso, põe-se a persegui-la.

\section{Ato III}

A abertura do terceiro ato é ao som da mais famosa passagem da tetralogia de Wagner: "A cavalgada das Valquírias". O ambiente é o topo de uma montanha onde as donzelas da guerra se reúnem para receberem os caídos em combate.

Eis que surge Brünnhilde carregando Sieglinde em seu cavalo. Ela pede às irmãs proteção frente à ira de Wotan. Sieglinde deseja a morte, mas ao saber que espera um filho de Siegmund aceita fugir para a floresta nas cercanias onde mora o gigante Fafner, levando consigo os fragmentos de Notung para que seu filho possa no futuro forjar para ele uma nova espada. Na despedida, Brünnhilde determina o nome que ela deverá dar ao filho: Siegfried. Após a fuga, chega Wotan irado. Ele quer que as Valquírias entreguem Brünnhilde, que aparece para enfrentar o pai. Wotan, irritado e magoado, trata-a como uma proscrita e decreta a punição: ela será colocada em sono profundo até que seja encontrada por um homem e tomada como mulher, o que significa que ela abandonaria a condição de imortal, o pior dos castigos. Entretanto, para poupá-la de uma união infame, Wotan a deixaria cercada por uma cortina de fogo para que somente um bravo herói pudesse desposá-la. Triste, ele abandona sua filha no seu sono, sob a proteção de uma muralha de chamas erguida com o auxílio de Loge.

\section{Siegfried}

Personagens: Siegfried, Mime, o andarilho, Alberich, Fafner, Erda, Brünnhilde, Pássaro. 


\section{Prelúdio e ato I}

No interior de uma caverna rochosa reencontramos Mime, irmão de Alberich, trabalhando uma peça de metal em uma bigorna. Ele reclama de não conseguir forjar uma espada que o jovem Siegfried não consiga quebrar. Sua esperança é conseguir um dia juntar os pedaços de Notung e enquanto isso sonha em conseguir para si o anel hoje guardado pelo gigante Fafner metamorfoseado em dragão com a ajuda do Tarnhelm.

Vemos entrar Siegfried puxando um urso por uma corda, que ele atira contra o medroso Mime, que foge. Passada a diversão, ele exige ver a nova espada que Mime forjara para ele, mas ela se quebra facilmente. Irritado com mais esse fracasso, Siegfried aproveita para interrogar Mime sobre as suas origens, já que para ele estava claro que não poderia ser filho do anão. Ameaçando esganá-lo, Siegfried arranca-lhe a verdade.

Mime encontrara um dia uma mulher vagando pela floresta e a trouxera para sua caverna. Ela acabara de dar a luz a um menino - Siegfried - e Mime o criara desde então, de acordo com o último desejo de sua mãe, Sieglinde. Desconfiado, Siegfried exige uma prova do relato e o anão lhe traz os fragmentos de Notung, que lhe foram entregues pela moribunda. $\mathrm{O}$ jovem anima-se com os fragmentos da espada, exige que o anão a conserte e em seguida retorna para a floresta.

Nisso surge um andarilho na entrada da caverna de Mime, usando um chapéu que lhe encobre um dos olhos. $\mathrm{O}$ andarilho lhe pede abrigo em troca de sabedoria, mas Mime não quer saber disso. Ele insiste e propõe um desafio de sabedoria: Mime poderia fazer-lhe as perguntas que quisesse e se ele errasse alguma, daria em troca sua cabeça. Mime aceita o desafio e pergunta: 1. “Que povo habita sob a terra?'. Os nibelungos, responde o andarilho. 2. "Que povo habita a superfície da terra?". Os gigantes, responde. 3. “Que povo habita as alturas nebulosas?”. Os deuses, responde finalmente o andarilho, que lhe repreende por não fazer perguntas mais úteis ${ }^{14}$. E diz que agora é sua vez de perguntar. Assustado, o anão submete-se à prova. A primeira pergunta refere-se ao nome da tribo que mesmo maltratada por Wotan é a preferida dos deuses. Mime responde: os Wälsungen. A segunda pergunta refere-se ao nome da espada que servirá a um jovem Wälsung criado por um certo nibelungo. É Notung, responde Mime. A terceira pergunta é: “Quem poderá forjar os fragmentos de Notung?". Mime, obviamente, não consegue responder a essa pergunta. $\mathrm{O}$ andarilho, porém, revela o

\footnotetext{
${ }^{14} \mathrm{O}$ tolo Mime poderia ter perguntado, por exemplo, “o que fazer para conseguir forjar Notung?”.
} 
mistério: só aquele que desconhece o medo poderá reconstituir a espada. E alerta Mime para que tenha cuidado com sua cabeça, pois ele a estava deixando "para aquele que desconhece o medo". Wotan parte deixando Mime atônito.

Mas ele entendera o recado: Siegfried é aquele que desconhece o medo. E, para salvar sua cabeça, o anão ardilosamente diz a Siegfried que antes dele aventurar-se pelo mundo deve aprender o medo. Para ensinar-lhe tal lição deveria segui-lo até a gruta de um dragão (certamente Fafner). Siegfried decide aprender o medo, mas insiste na forjadura da espada e decide ele mesmo forjá-la, já que Mime não conseguia fazê-lo. Enquanto ele trabalha na espada, Mime prepara uma poção para fazê-lo dormir tão logo ele tenha vencido o dragão, para em seguida matá-lo com sua própria espada e apossarse do anel. Finalmente Siegfried termina a forjadura da espada e para testá-la golpeia a bigorna, cortando-a em duas.

\section{Ato II}

Diante da caverna do dragão Fafner, vemos Alberich rondando enquanto é surpreendido pela chegada de Wotan. Tem início uma discussão entre os dois, ainda sobre a história do anel, com Alberich mostrando estar ciente de que Wotan pretende usar um jovem para conseguir o anel que ele, preso por um contrato, não pode conseguir por si mesmo. Mas Wotan o adverte de que seu inimigo é Mime, seu irmão, que logo chegara com o jovem Siegfried a quem está instruído para conseguir o anel.

Siegfried chega acompanhado de Mime, que insiste em lhe dar instruções sobre como vencer o dragão, mas o jovem não está interessado nelas, pois dispõe de seus próprios métodos. Depois de conseguir que Mime vá embora, deixando-o sozinho, ele se põe a divagar sobre os seus verdadeiros pais à sombra de uma árvore. Enquanto isso ele ouve um pássaro cantando e tenta comunicar-se com ele inutilmente e compreenderlhe a canção. Para tanto, improvisa alguns instrumentos musicais, mas desiste e resolve tocar sua trompa, só conseguindo com isso acordar o dragão.

Após uma breve discussão verbal, os dois travam uma luta que culmina com Siegfried cravando Notung no coração do dragão, que antes de morrer ainda tem tempo para narrar-lhe uma história. Ao extrair a espada do corpo de Fafner, ele suja sua mão com o sangue que ainda escorre da lâmina, o qual o queima. Levando a mão à boca em um impulso, ele prova o sangue e com isso consegue entender o canto do pássaro: ele lhe revela os poderes do anel e do Tarnhelm que estão no interior da gruta. 
Neste momento, Mime retorna e encontra Alberich. Os dois travam uma discussão sobre a propriedade do tesouro, discussão que cessa com a chegada de Siegfried. O pássaro adverte o jovem contra Mime e lhe informa que graças ao sangue do dragão, que provara sem querer, ele seria capaz de ouvir os pensamentos de Mime. Ao perceber que Mime intencionava matá-lo, Siegfried mata o anão com um golpe de espada, abandonando-o na caverna. Depois arrasta o corpo do dragão até a entrada da caverna e vai descansar à sombra de uma árvore. Aí, o pássaro lhe informa que uma noiva o espera, no topo de uma montanha, cercada pelo fogo.

\section{Ato III}

Vemos um rochedo e a abertura de uma gruta para a qual se dirige o "andarilho", que na verdade é Wotan, em seu traje de viajante. Ele procura Erda, pois precisa de seus conselhos. Ela lhe diz que tivera com ele uma filha sábia e corajosa e que Wotan poderia consultá-la. Sabendo que a deusa referia-se a Brünnhilde, ele lhe conta a atual situação da Valquíria, o que espanta Erda: "Aquele que deu lições de ousadia agora pune a ousadia?". Wotan continua atrapalhando o sono de Erda com perguntas que esta não responde. Por fim, Wotan lhe diz não mais temer a queda dos deuses, pois agora o mundo ficaria a cargo do Wälsung (Siegfried) que derrotaria Alberich. Erda retorna às profundezas da terra.

De onde estava o andarilho percebe a aproximação de Siegfried. O pássaro que o acompanhava foge ao ver o andarilho e Siegfried decide então perguntar-lhe - já que estava agora sem o seu pássaro-guia - sobre "um rochedo cercado de fogo, no qual dorme uma mulher". O andarilho inicia então um interrogatório através do qual Siegfried acaba por contar-lhe todo o incidente com o dragão. Entretanto, ele logo se irrita com tantas perguntas e tem início uma discussão com o andarilho, que exige mais respeito do jovem. A simpatia do andarilho pelo jovem (seu neto, posto que este é Wotan) começa a arrefecer durante a discussão, que se torna cada vez mais acirrada. Até o ponto em que Wotan, que antes queria que o jovem atingisse seu objetivo, decide impedi-lo bloqueando-lhe a passagem com sua lança. Brandindo Notung, Siegfried parte em dois a lança de Wotan, que desiste de tentar impedi-lo.

Siegfried chega então ao cume do rochedo e atravessa a muralha de fogo. Sobressaltado diante de algo que nunca vira, uma mulher, o jovem enfim conhece o medo. Após despertá-la com um beijo, ele acredita por um momento que talvez ela seja 
sua mãe, mas Brünnhilde conta-lhe então toda a história que os conduzira até ali e os dois então se abraçam cheios de amor.

\section{Crepúsculo dos Deuses (Götterdämmerung)}

Personagens: Siegfried, Gunther, Alberich, Hagen, Brünnhilde, Gutrune, Waltrante, as três nornas, as ninfas do Reno (Woglinde, Wellgunde, Flosshilde).

No penhasco de Brünnhilde vemos as três nornas, filhas de Erda, tecendo o fio do destino e conversando entre si sobre eventos passados. Elas relembram que, quando Wotan cortara o tronco da árvore do mundo para tecer sua lança, ela definhara e morrera, e que em seguida, quando um corajoso herói cortara a lança do deus ao meio, ele mandara fazer a árvore em pedaços, empilhando-os em torno do Valhalla. Um dia, comenta uma das nornas, eles se incendiarão, consumindo o Valhalla nas chamas. Tanto os deuses quanto os heróis aguardam esse dia. Após uma visão de Alberich com o anel roubado, a teia do destino se rompe nas mãos das nornas e elas retornam à terra.

Nasce o dia e vemos Brünnhilde despedindo-se de Siegfried, que parte para novas aventuras enquanto ela ficará aguardando. Vemos então a sala do trono de Gunther, rei dos Gibichungen, em um palácio às margens do Reno. Lá está Gunther na companhia de Gutrune, sua irmã, e Hagen, seu meio irmão, que lhe aconselha a casar-se e a encontrar um marido para sua irmã. Conta-lhe então de Brünnhilde, que jaz envolta por uma cortina de fogo esperando pelo herói Siegfried, único a poder conquistá-la. Gunther não entende onde o irmão quer chegar, já que está lhe sugerindo algo impossível. Ele expõe seu ardil: Gutrune conquistaria o herói fazendo-o beber uma poção que o faria esquecer de todas as outras mulheres. Encontrar o herói seria fácil, já que ele corria o mundo em busca de aventuras e logo passaria por terras Gibich.

E é exatamente isso o que acontece. Siegfried chega e logo os Gibichungen oferecem sua hospitalidade. Aproveitando a oportunidade, Hagen conversa com Siegfried sobre o tesouro nibelungo e o diálogo prossegue amistoso. Nisso Gutrune retorna com a poção mágica oferecendo-a em uma bebida para Siegfried, que logo após ingeri-la sente-se atraído por Gutrune e se oferece para desposá-la. Sabendo que o seu novo amigo Gunther não possui uma esposa, Siegfried se dispõe a buscar a mulher que ele desejar, ao que Gunther menciona Brünnhilde, e logo vê que Siegfried se esquecera totalmente dela. Os dois partem em busca da noiva. Enquanto isso, revela-se o motivo 
do ardil de Hagen: "Lá se vão eles, a conquistar a mulher. Um a trará para o outro como noiva, mas a mim ele trará o anel! Mal sabeis, felizes companheiros, que estais servindo ao filho do nibelungo!"

Enquanto isso, no rochedo, Brünnhilde recebe a visita de sua irmã Valquíria Waltrante, que lhe conta da lança quebrada de Wotan e que este mandara retalhar e empilhar o "freixo do mundo" ao redor da "grande sala" enquanto os deuses esperam ansiosos o que está por vir. Nesse desespero, Wotan pensa em Brünnhilde e acredita que tudo poderia ser salvo se ela devolvesse o anel que está sob os seus cuidados às ninfas do Reno. Mas ela não quer se desfazer dessa lembrança de Siegfried, que considera mais valioso que a "beatitude do Valhalla", e manda a irmã embora.

Então ela ouve a trompa de Siegfried e corre para encontrá-lo. Mas é um estranho que ela vê (Siegfried disfarçado de Gunther) que vem para tomá-la como esposa. Ele toma dela o anel e passa a noite ali, com a espada interposta entre eles, como testemunha de que não traíra Gunther, dormindo com sua noiva.

\section{Ato II}

Adormecido diante do palácio, Hagen recebe a visita de seu pai, Alberich, que exorta Hagen a seguir em frente com o plano, pois o resultado será o poder para ambos.

Siegfried retorna e logo em seguida Gunther chega com Brünnhilde. Siegfried anuncia a todos os súditos ali presentes o duplo casamento: o dele com Gutrune e o de Brünnhilde com Gunther. Brünnhilde está perplexa, e fica ainda mais quando vê no dedo de Siegfried o anel que Gunther tomara dela. A confusão se instala entre os presentes, que tentam se explicar, quando Brünnhilde declara ser esposa de Siegfried e que ele lhe presenteara o anel. Este, que não lembra de nada, nega tudo. Brünnhilde se sente traída, e Hagen se aproveita da situação oferecendo-se para vingá-la. E Brünnhilde, tomada pela ira, diz a Hagen que o ponto fraco de Siegfried são as costas (ela nunca lhe dera proteção ali, acreditando que ele jamais daria as costas a um oponente). Hagen convence Gunther de que Siegfried o traíra e que ele deve morrer.

\section{Ato III}

As ninfas do Reno brincam no rio quando Siegfried, que participava de uma caçada com Gunther, Hagen e outros Gibichungen, perde-se do grupo e vai parar ali. As

\footnotetext{
${ }^{15}$ Hagen é meio-irmão de Gunther por parte de mãe. E sua mãe, Grimhilde, tivera com Alberich um filho, Hagen.
} 
jovens ninfas pedem que lhes entregue o anel, mas ele recusa. Elas tentam alertá-lo da maldição do anel, mas ele não se importa com isso.

Ao longe ouvem-se toques de trompa de caça: são Hagen e os homens de Gibich. Siegfried, que havia se perdido deles, junta-se novamente ao grupo, onde já está Gunther, sombrio e pensativo. Os homens pedem para que Siegfried lhes conte a história de sua vida e ele começa a narrativa desde o tempo em que morava em companhia do anão Mime. Hagen oferece-lhe então uma bebida para lhe refrescar a memória, bebida esta que surtia um efeito oposto àquela poção que lhe fôra oferecida por Gutrune e causara o esquecimento de Brünnhilde. Siegfried passa então a narrar a história verdadeira de quando conheceu e desposou a Valquíria. Gunther conclui que o pacto de fidelidade fôra mesmo quebrado e que Siegfried seduzira sua noiva ${ }^{16}$. Passam dois corvos e, quando Siegfried se distrai olhando-os, Hagen golpeia o jovem nas costas com uma lança. Agonizante, este lembra-se agora de tudo e morre louvando Brünnhilde.

A cena retorna para o palácio dos Gibichungen, quando os homens de Gunther retornam com o corpo de Siegfried. A irmã de Gunther, Gutrune, desespera-se ao saber da morte do noivo e culpa o irmão. Gunther põe a culpa em Hagen, dizendo que ele matara Siegfried por conta do perjúrio. Hagen reivindica a posse do anel, mas Gunther o quer para si. Os dois lutam e Hagen mata Gunther, para em seguida tentar, novamente, apossar-se do anel que ainda está com Siegfried, mas ao aproximar-se do corpo, erguese o braço do morto, para o terror de todos.

Brünnhilde entra em cena e conta a todos a verdadeira história de seu desposamento por Siegfried. Gutrune amaldiçoa Hagen quando percebe o ardil no qual fôra envolvida, reconhecendo o amor de Siegfried e Brünnhilde. A Valquíria manda prepararem uma pira funerária para o herói e, tomando-lhe o anel, promete devolvê-lo às ninfas do Reno. Em seguida põe fogo na pira e, montada em seu cavalo, cavalga diretamente para as chamas. Todo o edifício se incendeia mas, subitamente, apaga-se e as águas do Reno sobem inundando tudo. Então surgem as ninfas do Reno. Quando as vê, Hagen se precipita na água em busca do anel, mas as ninfas arrastam-no para o fundo do rio.

Um clarão de fogo sobe aos céus iluminando todo o Valhalla, onde deuses e heróis estão reunidos em assembléia. O Valhalla é então consumido pelas chamas, anunciando o esperado fim dos deuses.

\footnotetext{
16 Lembremos que Gunther desconhecia essa primeira parte da história, tomando-a como tendo acontecido quando do acordo firmado com Siegfried para lhe conseguir uma noiva.
} 


\section{A reconstituição do paganismo germânico e o mito "vegetariano" da nova humanidade}

O resumo da Tetralogia do Anel que acabamos de apresentar serviu para mostrar, no contexto da obra de Wagner, toda a riqueza da mitologia germânica. Estão presentes aí suas divindades mais representativas, bem como os temas recorrentes da Germânia pré-cristã: o destino cósmico a que ninguém escapa, o significado mágicoritual das runas, a degradação progressiva do mundo (Ragnarok), sua posterior recriação implicada no "crepúsculo dos Deuses", e assim por diante. Mas essa longa apresentação da mais importante obra de Wagner cumpriu também a função de tornar claro ao leitor que a intenção de Wagner não era somente a de criar uma ópera sobre a saga do herói do Das Nibelungenlied (A canção dos nibelungos). A adaptação que Wagner faz a partir desse material acarretou o esquecimento do "verdadeiro" mito, instalando em seu lugar uma mitologia totalmente nova. Não será possível resumir aqui todas as peripécias do herói Siegfried no mito original, mas podemos esclarecer o essencial: apenas os nomes foram verdadeiramente preservados. Existe mesmo, no mito original, um herói chamado Siegfried, um anão chamado Alberich, uma jovem conhecida por Brünnhilde. Mas as semelhanças terminam aí. Não há, de fato, nenhum anel mágico em torno do qual gira o drama musical de Wagner nem os cruzamentos de deuses e homens no mesmo plano de ação como acontece na Tetralogia. Na Canção dos Nibelungos Siegfried não é fruto de uma relação incestuosa entre irmãos e nem mesmo é órfão. Ele é um príncipe lendário, filho do rei Siegmund e da rainha Sieglinde, soberanos de Xanten.

O drama em torno do tesouro dos nibelungos existe na versão original, mas no contexto daquilo que a história é - uma saga escrita para o gosto da aristocracia germânica. Os nibelungos, após terem descoberto um tesouro escondido em uma caverna, reuniram-se para tentar dividi-lo da forma mais justa possível. É aí que surge o nobre Siegfried, cavaleiro de grande fama por seus feitos heróicos e que por isso mesmo é convidado a arbitrar a divisão do tesouro, mas que acaba fazendo-o de uma forma desagradável a todos os nibelungos, que se lançam sobre ele em fúria. Brandindo sua espada Balmung, o jovem cavaleiro abate dois príncipes nibelungos, 700 guerreiros e 12 gigantes. Após sair vitorioso do combate, Siegfried recebe terras e burgos, além de tomar de um anão fiel aos nibelungos (Alberich) o manto da invisibilidade (Tarnhelm). 
Depois da capitulação de Alberich, que inicialmente pensava em vingar seus senhores, Siegfried converte-o no guardião do tesouro, que por sua ordem fôra reposto na caverna de onde havia sido retirado pelos nibelungos.

A saga dos nibelungos, em sua versão original, narrava de forma heroicizada a história de personagens e fatos acontecidos em um tempo remoto:

“Segundo Giordani, em 436, um exército de 20 mil burgúndios, liderados pelo rei Gundahar, foi totalmente exterminado por Aécio e seus mercenários hunos. Tal 'tragédia teve grande repercussão na épica germânica. Assim, por exemplo, a epopéia do Nibelungenlied, essa ilíada germânica, celebra Gunther, rei de Worms","17.

Richard Wagner, ao apropriar-se dessa história, não atualiza o mito: ele cria sua própria mitologia em torno de um tema caro aos alemães. A partir daí, Bayreuth se converterá no palco onde o compositor realizará o experimento de reforma da arte alemã a partir da fusão da mitologia germânica com a música.

Percebendo a relação entre a decadência do mundo ocidental e a corrupção da arte, convertida em artigo de consumo para um público superficial, Wagner propõe essa fusão como uma religião do teatro. O mito a partir do drama musical wagneriano (executado no teatro de festivais) tornaria possível o efeito catártico proporcionado pelos êxtases sagrados da música. A via musical realizaria, dessa forma, uma "arte integral" inspirada nos livros de cavalaria e nas lendas escandinavas da Edda ${ }^{18}$. Neste sentido, aponta Meleiro, "as produções simbólicas de Wagner remetem para uma Fonte Primitiva de Saber, para o mito, e são, em última análise, uma profunda alegoria ocultista acerca do mistério do homem e do universo" $" 19$.

A arte, para Wagner, havia sucumbido à lógica do mercado, enquanto o artista partilhava agora o mesmo destino do trabalhador manual. Refém da elite burguesa, que a utiliza em seu salão particular ao invés do teatro público, a essência da arte residiria agora na indústria. Sua finalidade moral seria o lucro financeiro e sua finalidade estética, o entretenimento dos entediados ${ }^{20}$. Assim,

"Esta arte fez do teatro o seu lugar de eleição, tal como tinha acontecido com a arte grega florescente. E conquistou esse direito porque é a expressão da vida pública

\footnotetext{
${ }^{17}$ Moniz, L. C. Mito e música em Wagner e Nietzsche, p. 94.

${ }^{18}$ Meleiro, M. L. F. A mitologia dos povos germânicos, p. 150.

${ }^{19}$ Idem, ibidem, p. 152.

${ }^{20}$ Wagner, R. A arte e a revolução, p. 59.
} 
vigente no nosso presente. A arte dramática moderna torna sensível o espírito dominante da vida pública, exprime-o numa dimensão quotidiana que não tem paralelo em nenhuma outra arte e em nenhum outro tempo uma vez que leva a cabo os seus festejos noite após noite praticamente em todas as cidades da Europa. E deste modo, revestindo a forma de uma arte cênica de enorme expansão, a arte moderna parece ser o que há de mais característico no florescimento da nossa cultura, como a tragédia caracterizava o apogeu do espírito grego. Mas este florescimento é o da podridão de um estado de coisas vazio, destituído de espírito e contrário à natureza" ${ }^{21}$.

Espelho fiel do espírito dominante na sociedade, a arte moderna representaria agora o momento de distração para o príncipe que comparece ao teatro após um trabalhoso banquete, para o banqueiro após um longo dia de especulações financeiras e, por último, para o operário após um cansativo dia de trabalho, todos a procura de distração e divertimento. E existia para isso um grande número de artistas que não teriam nenhuma outra ambição a não ser a de satisfazer as expectativas desse público.

À arte privada moderna, Wagner contrapõe, muito de acordo com seu espírito romântico, a arte pública dos gregos com todo o vigor mitológico e religioso:

"Porque, na tragédia, o Grego reencontrava-se a si mesmo, sobretudo, reencontrava a parte mais nobre de si próprio enlaçada com os mais nobres elementos da essência geral do conjunto da nação. Por intermédio da obra de arte trágica, o Grego exprimia a sua interioridade, dava voz ao oráculo da Pítia que transportava no mais íntimo de si mesmo"22.

Esse "delicioso perfume da eternidade" do mundo grego, cuja arte seria alegria de ser e júbilo pela existência presente, estava em total desacordo com o desprezo próprio e a recusa da existência, típicas do declínio do império romano e cuja principal expressão não podia ser a arte, mas o Cristianismo. Inspirado por Feuerbach, o Wagner ainda revolucionário e nietzscheano contrapõe ao vigor do homem grego (colocado no ponto culminante da natureza) o homem cristão, que rejeita a si mesmo e à natureza:

"Os fatos históricos manifestaram com a maior clareza a sorte destes dois direcionamentos contraditórios. Enquanto o homem grego se reunia nos anfiteatros

\footnotetext{
${ }^{21}$ Idem, ibidem, p. 60. O grifo é nosso.

${ }^{22}$ Idem, ibidem, p. 43.
} 
durante poucas horas, contudo plenas do mais profundo conteúdo edificante, o cristão entregava-se uma vida inteira à clausura do mosteiro"23.

Mas o ímpeto revolucionário de Wagner, que derivava do contato com o socialista Proudhon, a clássica "Qu'est-ce que la propriété" (1840) e da leitura de "A essência do cristianismo" de Feuerbach (1841), bem como de sua militância nos levantes de Dresden em 1848 ao lado do amigo anarquista russo Mikhail Bakunin, não demoraria a arrefecer. A crença de Wagner na arte e na mitologia grega, bem como sua percepção do cristianismo como uma negação da natureza, iria conduzi-lo inevitavelmente pelo mesmo caminho dos românticos: de volta à natureza.

"Quando o médico e o seu saber acadêmico não encontram remédio, o nosso desespero costuma levar-nos de volta à natureza. E em boa verdade só a natureza pode desenredar o grande destino que a humanidade tem à sua frente. Se a cultura procedeu à negação do homem com base na crença cristã na indignidade humana, criou ao mesmo tempo o inimigo que a há-de aniquilar na exata medida em que ela não dispõe de lugar para o homem. Esse inimigo é a natureza, a única fonte perpétua de vida” ${ }^{24}$.

À cultura, fonte de todo o mal, Wagner contrapõe a natureza, fonte de uma temível força capaz de desencadear a "revolução". Eis aí a fundamentação da utopia místico-revolucionária que Wagner expressará, de certa forma, através da Tetralogia do Anel.

O cerne da obra, representado pelo conflito entre o amor e o poder, é essencialmente schopenhaueriano, quer dizer, "essencialmente renunciador, aceitando o 'mal intrínseco' aos anseios humanos e considerando repreensível o 'desejo de viver"'. O tema do amor verdadeiro, por sua vez, revela sinais tanto de Proudhon quanto de Feuerbach, por isso a felicidade no amor residiria além do casamento em sua forma institucionalizada que representaria a oficialização e a perpetuação de direitos de propriedade. Por isso todos os casamentos descritos no Anel são sem amor, com o amor verdadeiro sendo encontrado apenas fora do casamento, como no caso da relação incestuosa entre Siegmund e Sieglinde ${ }^{25}$.

\footnotetext{
${ }^{23}$ Idem, ibidem, p. 51.

${ }^{24}$ Idem, ibidem, p. 87.

${ }^{25}$ Millington, B. Wagner: um compêndio, p. 327.
} 
"A crítica de Wagner era evidentemente dirigida não apenas contra as relações sexuais feudais dos tempos mitológicos, mas também contra a situação reinante em sua época, como aliás fica claro em seus vários escritos daquele período. Similarmente o Anel contém críticas das relações de produção, do destrutivo - e alienante - poder do capital e da exploração e opressão tanto na esfera industrial quanto na social"26.

Ou seja, como Barry Millington faz questão de ressaltar, mais do que uma aventura sobre anões e gigantes, a Tetralogia do Anel dos Nibelungos é uma alegoria do conflito entre natureza e cultura, conflitos que surgem quando "a civilização e a política do poder invadem o inocente mundo natural" ${ }^{, 2}$. O recurso aos temas mitológicos, calcado na crença de que a lenda seria mais verdadeira que a história, representava também uma reação contra o cristianismo e uma revalorização romântica das lendas germânicas. No rastro dessa revalorização do passado ancestral, Wagner resume, como aponta Poliakov, a teoria ariana da origem da humanidade: "É sobre essas montanhas [o Himalaia] que devemos procurar a pátria primitiva dos atuais povos da Ásia e de todos os povos que emigraram para a Europa. Lá está a origem de todas as civilizações, de todas as religiões, de todos os idiomas (...)" ${ }^{, 28}$.

Quanto a Schopenhauer, mesmo antes de 1854, o livro $O$ mundo como vontade e representação já vinha sendo discutido nos círculos de amigos de Wagner em Zurique, e no ano seguinte ele já tomara contato com as lendas da Índia e com o budismo, que iriam influenciar a composição de Parsifal. A partir do contato com Schopenhauer, Wagner ficará dividido entre o otimismo expressado tanto em $A$ arte e a revolução quanto em A obra de arte no futuro (ambas de 1849), e o pessimismo de $O$ mundo como vontade e representação.

O livro de Schopenhauer, assim como os escritos de seus predecessores - Fichte e Schelling - estava vinculado ao ambiente romântico alemão do final do século XVIII e começo do século XIX. Influenciado pelo budismo e pelo hinduísmo, Schopenhauer considera a "vontade" como a essência do mundo. Por conta da vontade, os homens são iludidos, posto que ela jamais é saciada, sendo o mundo como objetivação da vontade, o reino da miséria e da escravidão. Afirma Sciacca sobre o pessimismo de Schopenhauer:

\footnotetext{
${ }^{26}$ Idem, ibidem, p. 327.

${ }^{27}$ Idem, Ibidem, p. 38 e 356.

${ }^{28}$ Wagner, R. Os nibelungos. História universal extraída da lenda, citado por Poliakov, L. De Voltaire a Wagner, p. 368.
} 
"Mas o homem pode libertar-se da dor e subtrair-se ao domínio tirânico da vontade. Viver, mais que mal, é delito e continuar a viver é culpa. O mundo não merece que exista. É inútil aguardar-se a libertação pelo progresso e pela civilização. $\mathrm{Na}$ história não há progresso: a vontade em todos os seus graus é sempre cega e sem escopo; a história é o manifestar-se da incansável vontade de viver que repete sempre a mesma tragédia ou comédia, mesmo se os personagens, ou melhor, os comparsas mudam"29.

A tonalidade mística, por fim, acabará prevalecendo. Na primeira edição do Anel (1853), o final do texto é alterado. A cena do triunfo do herói é eliminada e em substituição a ela vemos a destruição dos deuses e do Valhalla pelo fogo. Wagner insiste já ter tomado essa decisão antes da influência de Schopenhauer. De qualquer forma, o final trágico do Anel combina tão bem com a descrição do apocalipse escandinavo (Ragnarök) que poderia mesmo prescindir da influência de Schopenhauer. Mas as alterações no texto prosseguirão, agora já de pleno acordo com o tema central de $O$ mundo como vontade e representação. No final escrito em 1856 ("final Schopenhauer"), a heroína Brünnhilde volta-se para um conforto metafísico mais elevado, como aponta Hollinrake:

"Se já não viajo para a fortaleza do Valhalla, sabeis para onde irei? Sairei do lar do desejo e escaparei para sempre do lar da ilusão. Fecharei atrás de mim os portões abertos do perpétuo devir. Iluminada e redimida da reencarnação, avançarei para a mais santificada das terras eleitas, para além do desejo e da ilusão, no término da jornada terrena. Sabeis como atingi a meta bem-aventurada de tudo o que é eterno? A mais profunda dor de amor angustiante e lamentoso abriu meus olhos: eu vi o fim do mundo" $" 30$.

O mito que tinha como tema central a renúncia ao amor e a luta pelo poder, termina agora como uma insossa renúncia da "vontade", incapaz de engendrar uma futura humanidade, como queria Wotan. Só nesse contexto é possível entender o desaparecimento do desfecho revolucionário. O otimismo grego sucumbe assim ao niilismo.

\footnotetext{
${ }^{29}$ Sciacca, M. F. História da Filosofia, vol. 3, p. 63. Sobre a relação de Schopenhauer com a filosofia oriental, convém consultar também Schopenhauer e o oriente, Fábio L. de A. Mesquita, dissertação de mestrado, FFLCH-USP, 2007.

${ }^{30}$ Citado por Hollinrake, R. Nietzsche / Wagner e a filosofia do pessimismo, p. 79.
} 
Nietzsche, por muito tempo amigo de Wagner e seu principal propagandista, por conta de seu envolvimento pessoal com o compositor demorou a perceber a guinada de Wagner da exaltação do mundo grego para o pessimismo schopenhaueriano e, ainda pior, sua conversão à mitologia cristã. Ele acusa Wagner de bater-se constantemente com o tema da "redenção", pois haveria sempre alguém tentando se redimir. No caso do Anel, Wotan, o velho deus, depois de haver se comprometido moralmente, seria finalmente redimido por um livre-pensador. Mas nessa obra, o verdadeiro redimido teria sido o próprio Wagner: "Durante meia vida Wagner acreditou na revolução, como só um francês podia acreditar. Ele a procurou na escrita rúnica do mito, e pensou encontrar em Siegfried o revolucionário típico" ${ }^{\text {31 }}$.

À pergunta: "De onde vêm todas as desgraças do mundo?", o compositor teria respondido na trama do Anel: "dos velhos contratos", como todos os ideólogos da revolução. A solução para esse problema seria então a abolição dos velhos contratos (tradição, moral), empreitada deixada a cargo de Siegfried. Coisa que ele começa a fazer bem cedo, nascendo de uma relação incestuosa. Sua empresa maior, ironiza Nietzsche, seria "emancipar a mulher", no caso, Brünnhilde: (ainda mais irônico) "Siegfried e Brunilda; o sacramento do amor livre; o advento da era dourada; o crepúsculo de ídolos da velha moral - o infortúnio foi abolido...". Mas a nave de Wagner, que seguia contente nesse curso, encalhou no recife da filosofia de Schopenhauer. Aquilo que Wagner havia posto em música, o otimismo, era o oposto da filosofia schopenhaueriana, e para o qual existia até um adjetivo mau - o de "otimismo infame". Wagner naufragou ali, e entendeu o próprio naufrágio como uma meta. Traduzindo o anel em termos schopenhauerianos:

"tudo vai torto, tudo afunda, o novo mundo é tão ruim quanto o velho - o nada, a Circe indiana, nos acena... Brunilda, que segundo a antiga intenção se despedira com uma canção de louvor ao amor livre, deixando ao mundo esperanças de uma utopia socialista, com a qual 'tudo fica bom', agora tem outra coisa a fazer. Deve primeiro estudar Schopenhauer, tem de pôr em versos o quarto livro do Mundo como vontade e representação. Wagner estava redimido"32.

Após a Tetralogia do Anel, Wagner passa a ocupar-se de Parsifal, obra prenhe de simbolismo cristão, apesar da presença de temas caros ao paganismo e ao budismo.

\footnotetext{
${ }^{31}$ Nietzsche, F. O caso Wagner, p. 16-17.

${ }^{32}$ Idem, Ibidem, p. 17-18.
} 
O tema, já conhecido de todos, remontava ao poema épico Parzivâl, de Wolfram von Eschenbach, escrito no século XIII. O tema central do drama é a busca do Santo Graal, então identificado (graças a influências posteriores) ao cálice sagrado com o qual, segundo a lenda, José de Arimatéia teria recolhido o sangue de Jesus Cristo.

Nietzsche não perdoará essa capitulação moral do ex-amigo. Em um texto de 1888, denominado muito sugestivamente Nietzsche contra Wagner, ele trata Wagner e Schopenhauer como seus antípodas, ao caluniarem e negarem a vida. E sobre Parsifal, com uma sutileza toda peculiar, ele fulmina:

"Pois o Parsifal é uma obra de perfídia, de vingança, de secreto envenenamento dos pressupostos da vida, uma obra ruim. - A pregação da castidade é um estímulo à anti-natureza: eu desprezo todo aquele que não percebe o Parsifal como um atentado aos costumes" 33 .

Hollinrake aponta que Wagner já vinha há algum tempo elaborando um projeto que tratasse dos mistérios e da Paixão de Cristo e que o Parsifal talvez tenha representado essa antiga ambição. Afirma também que, ao aceitar a teoria então corrente de uma raça ariana, Wagner teria exilado o Graal para uma montanha da Índia, interpretando assim o cristianismo como a recrudescência de um impulso religioso originado no extremo oriente ${ }^{34}$. Nietzsche se insurgirá contra isso na Gaia ciência, ao acusar Wagner de considerar o cristianismo como um grão disperso do budismo ${ }^{35}$.

E Poliakov resume assim essa religião instituída por Wagner (cuja bíblia eram suas partituras e o templo o teatro em Bayreuth), misto da antropodicéia de Schlegel, da metafísica anti-judaica de Schopenhauer, e tudo isso somado com as leituras racistas de Gobineau:

"Outrora, nos tempos da idade de ouro, os homens viveram numa inocência primitiva e vegetariana, nos altos planaltos asiáticos. Mas sobreveio o pecado original, com a primeira morte de um animal; desde então, a sede de sangue se apodera do gênero humano, que multiplicava os assassinatos e as guerras, e em sua esteira, as conquistas, os exílios, as vagueações. Cristo, um Cristo indiano ou ariano, tentara salvar os homens indicando-lhes o caminho de retorno para a inocência vegetariana primitiva, que exprimia a eles na refeição da Ceia pela transformação do sangue em vinho e da

\footnotetext{
${ }^{33}$ Nietzsche, F. Nietzsche contra Wagner, p. 65.

${ }^{34}$ Hollinrake, R. Nietzsche / Wagner e a filosofia do pessimismo, p. 153.

${ }^{35}$ Nietzsche, F. A gaia ciência, p. 112.
} 
carne em pão; depois, 'deu sua vida em expiação ao sangue derramado pelos homens carnívoros desde o começo do mundo'. Mas uma igreja judaizada teria pervertido o sentido dessa mensagem, de modo que o gênero humano teria continuado a degenerar, poluído pela carne animal de um lado, pelos venenos do sangue judeu, de outro. 'Sendo o judeu o demônio plástico da decadência da humanidade', e a civilização ocidental, uma 'confusão judeu-bárbara', o fim apocalíptico estava próximo. Só existia uma esperança de salvação: uma nova purificação, uma nova recepção do sangue sagrado, segundo os ritos do mistério de Parsifal, o redentor germânico"36

O vegetarianismo de Wagner, que se supõe haver inspirado aquele de Hitler, derivava da idéia de que o homem teria degenerado a partir do consumo de carne. Nisso reside, junto com o envenenamento do sangue pelo cruzamento com judeus, a degeneração da raça humana. O novo homem preconizado pelo compositor deveria ser regenerado através do vegetarianismo e da arte inspirada pela narrativa mítica como aquela nascida em Bayreuth, o que excluía os judeus, principais responsáveis pelo declínio da arte, convertida agora em negócio. Não é possível afirmar de forma categórica, apesar dos indícios, que o anti-semitismo de Wagner esteja mesmo calcado na idéia de raça ou se trata-se apenas de uma repulsa à posição dos judeus como representantes do capitalismo moderno, afinal, Wagner fôra, no passado, inspirado pelo comunismo. Mas a sua amizade com Gobineau e o fato de que Chamberlain, outro antisemita notório, era casado com uma de suas filhas nos leva a crer que essa "nova humanidade" passava necesariamente pela purificação racial.

Sua influência sobre Hitler, porém, é indiscutível. Fest, biógrafo de Hitler, nota que "a música de Richard Wagner, com seu apelo patético à emoção, sua tonalidade estranhamente encantatória e maléfica, seu imenso poder de fascínio, proporcionou-lhe

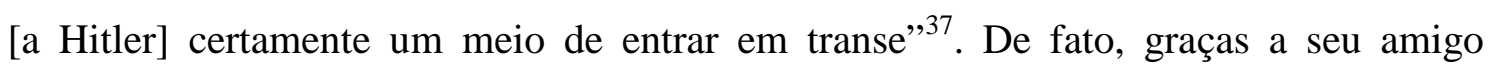
August Kubizek, de seus tempos em Linz, sabemos o quanto a música e a mitologia de Wagner impressionaram o jovem Hitler. Sua personalidade megalomaníaca combinava perfeitamente com as celebrações épicas de deuses e heróis das óperas de Wagner. E Fest conclui:

"Um como outro [Hitler e Wagner] eram animados de uma vontade de poder exacerbada, de uma tendência essencialmente despótica, e a arte de Richard Wagner nunca conseguiu fazer esquecer de todo a que ponto ele estaria a serviço de uma vasta

\footnotetext{
${ }^{36}$ Poliakov, L. O mito ariano, p. 309.

${ }^{37}$ Fest, J. Hitler, p. 23.
} 
manobra de domínio. Assim se explica seu gosto tão irresistível quanto equívoco sobre o plano da arte pelo espetáculo de massas, as manifestações imponentes e embriagadoras por serem desmedidas (...) Sem essa tradição da ópera, sem a arte propriamente demagógica de Richard Wagner, o estilo representativo do III Reich é inconcebível" 38

Os grandes comícios, a tetralidade das manifestações públicas, os estandartes, as grandes representações de força e poder como as marchas da SS pelas ruas da Alemanha, os símbolos (a águia e a suástica) e a afetação dos discursos do Führer representavam a magia da arte a serviço do poder. E Hitler tinha plena consciência da "magia sugestiva" desses símbolos como ele mesmo informa no Mein Kampf. Como bem notou T. W. Adorno, na Alemanha nazista:

\footnotetext{
“A religião foi integrada como patrimônio cultural, mas não abolida. A aliança entre o esclarecimento e a dominação impediu que sua parte de verdade tivesse acesso à consciência e conservou suas formas reificadas. As duas coisas acabam por beneficiar o fascismo: a nostalgia incontrolada é canalizada como uma rebelião racista; os descendentes dos visionários evangelizadores são convertidos, segundo o modelo wagneriano dos cavaleiros do Santo Graal, em conjurados da confraria do sangue e em guardas de elite; a religião enquanto instituição é, em parte, confundida de maneia direta e inextricável com o sistema e, em parte, transposta na pompa da cultura de massa e das paradas $^{39}$.
}

\footnotetext{
${ }^{38}$ Idem, Ibidem, p. 52.

${ }^{39}$ Adorno; Horkheimer. Dialética do esclarecimento, p. 164-165.
} 


\section{CAPÍTULO IV: O NAZISMO ESOTÉRICO}

\begin{abstract}
"Por 1880, em França, na Inglaterra e na Alemanha, algumas sociedades iniciáticas e ordens herméticas são fundadas, reunindo poderosas personalidades. A história desta crise mística e pós-romântica não foi ainda escrita e mereceria sê-lo. Ali se encontraria a origem de muitas importantes correntes de pensamento, que também determinaram correntes políticas..."
\end{abstract}

(Louis Pawells e Jacques Bergier)

\section{O sanatório das coincidências exageradas}

Em 1960, Louis Pauwels e Jacques Bergier publicam um livro que iria exercer grande influência sobre os leitores ávidos pelo ocultismo. Bergier era físico e Pauwels, além de jornalista, pertencia ao círculo de Guénon e Gurdijieff, influentes representantes do neo-ocultismo do século XX. O livro intitulado $O$ despertar dos mágicos tinha como subtítulo "introdução ao realismo fantástico".

Para que possamos entender esse livro, que consiste em uma mistura de informações sobre pessoas e coisas insólitas, além de doutrinas místicas e sociedades secretas, convém retornarmos a Charles Hoy Fort, um jornalista e "embalsamador de borboletas" que vivia em Nova York por volta de 1910, porque será dele que Pauwels e Bergier irão derivar sua "metodologia" de trabalho.

Charles Fort era um obcecado colecionador de notícias de jornais e revistas de todos os Estados e de todas as épocas, que ele conseguia a partir de pesquisas na Biblioteca Municipal de Nova York e de correspondências com bibliotecas do mundo todo. Sua coleção de notas, com mais de 25.000 itens, organizados diligentemente em caixas de papelão, reuniam todos os eventos extraordinários de que se tinha notícia, ou melhor, de que se tinha registro:

"No dia 2 de novembro de 1819, chuva vermelha sobre Blankenberghe, no dia 14 de novembro de 1902, chuva de lama na Tasmânia. Flocos de neve do tamanho de pratos em Nashville, a 24 de janeiro de 1891. Chuva de rãs em Birmingham a 30 de junho de 1892. Aerólitos. Bolas de fogo. Pegadas de um animal fabuloso no Devonshire. Discos voadores. Marcas de ventosas sobre montanhas. Engenhos no céu. 
Caprichos de cometas. Desaparecimentos estranhos. Cataclismos inexplicáveis. Inscrições sobre meteoritos. Neve preta (...)" ${ }^{\prime 1}$.

Tais fatos, tão logo eram mencionados em jornais e revistas, já eram esquecidos, ignorados pela ciência. E, de certa forma, era isso o que incomodava Charles Fort: tais coisas eram fatos documentados e que não deviam ser relegados ao esquecimento. Fort denominava seu arquivo de fatos insólitos de "sanatório das coincidências exageradas".

Depois de alguns anos nessa empreitada, ele percebe que o mero acúmulo de informações desse tipo não serviria para nada, não representava um verdadeiro estudo, uma verdadeira investigação. Desanimado, ele ateia fogo ao seu arquivo e decide, ao longo de oito anos, estudar todas as artes e todas as ciências. Enquanto isso, decide retomar suas investigações sobre os fatos discordantes das teorias científicas em vigor. Mas, desta vez, ele não se contenta apenas em sumariar dados; ele pretende, como faz a ciência, elaborar explicações, aventar hipóteses. O que não significa que ele tenha se deixado convencer pela ciência: era preciso demolir a ciência vigente e começar tudo novamente. Recomeçar reinserindo os fatos excluídos sobre os quais ele dedicara anos de estudo. Na intenção de levar adiante sua missão reformadora, publica $O$ livro dos danados:

"Coleciono notas sobre todos os assuntos dotados de qualquer diversidade, tais como os desvios da concentricidade na cratera lunar Copérnico, a súbita aparição de britânicos cor de púrpura, os meteoros estacionários, ou o súbito nascimento de cabelos sobre a cabeça calva de uma múmia. No entanto, o meu maior interesse não tem como objeto os fatos, mas as relações entre os fatos. Meditei muito a respeito das supostas relações a que chamamos coincidências. E se não houvesse coincidências?”².

Um pouco místico, um pouco cientista, mas sobretudo um descontente com a filosofia da ciência era Charles Fort, que não se definia nem como realista e nem como idealista, mas como um "intermediarista", seja lá o que isso signifique. Pauwels e Bergier notam que ele insurgira-se contra a falta de realismo na ciência, que recusa a realidade sempre que ela se mostra fantástica. Eles também não consideram Fort um ocultista: faltam-lhe os delírios do pensamento por analogia, tão típico dos ocultistas, por mais que suas 40.000 notas sobre todos os tipos de chuva (incluindo,

\footnotetext{
${ }^{1}$ Pauwels e Bergier, $O$ despertar dos mágicos, p. 137.

${ }^{2}$ Charles Fort, O livro dos danados, citado por Pauwels e Bergier, O despertar dos mágicos, p. 145.
} 
provavelmente, as de sapos e peixes) que caem sobre a terra tenham lhe levado a concluir que a maior parte delas não seria de origem terrestre. Provinham de outras existências nos espaços, de "outras dimensões", diríamos hoje. Pauwels e Bergier concluem:

\footnotetext{
"Digamo-lo imediatamente. Fort não é um ingênuo. Ele não acredita em tudo. Apenas se insurge contra o hábito de negar a priori. Não aponta com o dedo as verdades: desfere golpes para demolir o edifício científico da sua época, constituído por verdades tão parciais que dir-se-iam erros”3.
}

O despertar dos mágicos segue a mesma lógica dos escritos de Fort, e os autores definem sua "escola" como realismo fantástico, o que, para eles, não significa "alguma preferência pelo insólito, pelo exotismo intelectual, pelo barroco, pelo pitoresco" Trata-se, porém, de encarar o fantástico como uma manifestação das leis naturais, que se apresenta quando a realidade não foi ainda filtrada pelo intelecto.

Entretanto, aquilo que Charles Fort, Pauwels e Bergier fazem, e que Fort denominou, de forma muito espirituosa, como "o sanatório das coincidências exageradas", nada mais é que o saber que os gregos denominavam Paradoxologia. Trata-se da coleta e, por vezes, da interpretação de fatos extraordinários. Essa "ciência dos prodígios", afirma Pierre Riffard, um historiador do esoterismo, "encontra-se na fronteira da lenda e da história, uma disciplina que não praticam nem os folcloristas nem os historiadores", e tais relatos não apresentam nem a profundidade metafísica e nem o rigor científico ${ }^{5}$. O que motiva os autores, conclui, é a curiosidade e o desafio às idéias admitidas.

Tais esclarecimentos precisavam ser prestados porque o livro de Pauwels e Bergier pode ser considerado a mais importante e mais influente referência acerca das relações entre as concepções nazistas e as idéias ocultistas e seitas secretas a que nos dedicaremos neste trabalho. Estamos totalmente conscientes, porém, das dificuldades que essas obras de paradoxologia representam para o pesquisador: referências que são constantemente omitidas (como é característico dos escritos esotéricos), interpretações fantasiosas, fatos extravagantes, enfim. Tais obras, como bem notou Riffard, atraem os esoterólogos por apresentarem "personagens enigmáticos, doutrinas místicas,

\footnotetext{
${ }^{3}$ Pauwels e Bergier, O despertar dos mágicos, p. 148.

${ }^{4}$ Idem, ibidem, p. 18.

${ }^{5}$ Riffard, P. O esoterismo, p. 121.
} 
sociedades secretas, fatos metapsíquicos" que nunca são contextualizados historicamente, já que tal empreendimento destruiria o próprio objeto da paradoxologia ${ }^{6}$. E, é desnecessário dizer, tais objetos também desapareceriam se fossem submetidos ao escrutínio da ciência. É por isso, também, que "a paradoxologia cai inevitavelmente num dilema: ou ela é descritiva e portanto anedótica, superficial, ou ela é explicativa e confunde inexplicado e desconhecido, curioso e oculto"7.

Optamos, então, por apresentar o problema tal como ele aparece no livro de Pauwels e Bergier, já que de certa forma é ele quem impulsiona as investigações acerca do "nazismo mágico". Como se trata de uma obra de paradoxologia, o livro apresenta uma miríade de fatos extraordinários acerca de Hitler e do nazismo, cujo objetivo é desafiar as interpretações psicológicas, sociológicas e históricas "clássicas" sobre as origens e a evolução do III Reich, muito de acordo com as críticas de Charles Fort de que a ciência tem por hábito relegar ao esquecimento tudo aquilo que não consegue explicar. O mérito do livro de Pauwels e Bergier consiste nisso: em instar os historiadores a pesquisarem suas afirmações, com todos os problemas que isso implica, por tratar-se de uma obra que mesmo não sendo esotérica partilha de muitos dos seus defeitos, sobretudo no que diz respeito à confiabilidade de suas fontes.

Algumas dessas informações foram confirmadas por pesquisas históricas ulteriores, outras foram rejeitadas. Algumas especulações são hoje consideradas plausíveis, outras devem ser creditadas ao misticismo dos autores. Consideraremos, inicialmente, todas elas. Em seguida trabalharemos apenas aquelas sobre as quais paira algum consenso, ou seja, realizaremos um trabalho oposto ao sugerido pelos paradoxologistas: submeteremos ao escrutínio da ciência histórica todo o "maravilhoso", porque pensamos que nem tudo aquilo que é "curioso" deve ser considerado "oculto" ou mesmo "miraculoso". Contra os paradoxologistas, somos obrigados a invocar o princípio de economia ou a Navalha de Ockham: "é inútil fazer com mais o que se pode fazer com menos", ou seja, se existem duas hipóteses igualmente capazes de explicar um mesmo fato, devemos escolher a hipótese mais simples. No caso, a menos "miraculosa".

\footnotetext{
${ }^{6}$ Idem, Ibidem, p. 121.

${ }^{7}$ Idem, Ibidem, p. 122.
} 


\section{O realismo fantástico das influências nazistas ${ }^{8}$}

Em uma manhã de 1925, todos os cientistas da Alemanha e da Áustria receberam uma curiosa carta que no fundo era um ultimato:

“Agora é preciso escolher, ou conosco ou contra nós. Ao mesmo tempo que Hitler limpará a política, Hans Horbiger destruirá as falsas ciências. A doutrina do gelo eterno será o sinal da regeneração do povo alemão. Atenção! Coloquem-se do nosso lado antes que seja demasiado tarde", .

O cientista que assinava a carta era o próprio Hans Horbiger, que aos 65 anos de idade apresentava-se como o profeta da nova ciência alemã. Nascido em 1860, Horbiger estudara na Escola de Tecnologia de Viena para em seguida empregar-se como desenhista de máquinas a vapor e então especialista em compressores em Budapeste, onde faria fortuna após ter inventado um novo sistema de torneiras para bombas e compressores. A partir de seus estudos acerca das mudanças de estado da água, Horbiger desenvolveu a obsessão de tentar revolucionar a astronomia de sua época, explicando toda a cosmografia e a astrofísica através dos estados sólido, líquido e gasoso. Graças a algumas intuições místicas, que ele supunha científicas, Horbiger desenvolveu um sistema da evolução do cosmos que explicava a formação da terra, a origem da vida e dos espíritos de uma só vez. Como todo grande sistema místico, ele pretendia fornecer respostas às três grandes questões da humanidade: Quem somos nós? De onde viemos? Para onde vamos?

Seu raciocínio assentava-se na concepção da luta eterna entre o gelo e o fogo e entre as forças de atração/repulsão presentes na natureza como pares opostos. Tal luta e tensão que regia a evolução do cosmos seria também responsável pela criação da Terra, pela criação da matéria viva e conseqüentemente determinaria a história humana. Fazendo remontar a história da evolução a milhares de anos no passado, tal teoria também era capaz de avançar no futuro, introduzindo fantásticas noções acerca da evolução das espécies.

De acordo com a teoria de Horbiger, não há uma evolução no sentido de um progresso contínuo, mas uma sucessão de ascensões e declínios. Sendo assim, teríamos

\footnotetext{
${ }^{8}$ Salvo considerações em contrário, essas "teorias" foram tomadas de Pauwels e Bergier, O despertar dos mágicos.

${ }^{9}$ Citado por Pauwels e Bergier, p. 258.
} 
sido precedidos há milhares ou milhões de anos por homens-deuses, gigantes e civilizações mais avançadas que a nossa e por isso poderíamos, a partir de mutações e cataclismos, voltar a ser como os antepassados de nossa raça, que por sua vez pereceram através de um idêntico processo.

Após uma "revelação", ele deduz a real história da criação do universo, que será alçada ao status de "teoria científica" definitiva sobre o assunto. Brilhava no céu, há muito tempo, um enorme corpo milhões de vezes maior que o sol, que entrou em colisão com um planeta gigante formado por gelo cósmico. Tal massa de gelo, após penetrar profundamente nesse super astro primordial de fogo, permaneceu ali durante milhões de anos até que o vapor formado em seu interior pelo derretimento do gelo e sua passagem à forma de vapor o fez explodir. Alguns fragmentos dessa explosão perderam-se no infinito gelado, outros sobre a massa da explosão original, enquanto um terceiro grupo de fragmentos foi atirado em uma zona intermediária, formando os planetas que conhecemos, em número de trinta. Tais fragmentos pouco a pouco foram recobertos por gelo, sendo assim, a Lua, Júpiter, Saturno e Marte seriam formados por gelo. Apenas na Terra, não inteiramente tomada pelo frio, desenrolava-se ainda a luta entre gelo e fogo.

As manchas que observamos no sol (as manchas solares) seriam blocos de gelo caídos de Júpiter sobre o nosso sol e a Via-Láctea seria um enorme anel de gelo formado a partir da explosão primordial. A zona média da explosão, onde se encontram os planetas de nosso sistema solar, estaria sob o domínio de duas forças de intensidades diferentes. A primeira, a força da explosão, vai diminuindo gradativamente; a segunda, a força de gravitação ou de atração é constante, mas obriga os planetas a orbitarem em uma espiral cada vez maior do corpo de maior massa. O espaço que consideramos vazio não estaria de fato vazio, mas preenchido por uma mistura de hidrogênio e vapor d'água. Um dia, graças à atração da gravidade, os planetas de gelo cairão sobre o sol, dando origem a uma nova explosão e tudo terá um novo começo.

Quanto ao destino da Terra, a cada dia a Lua orbitaria mais próximo do nosso planeta, até que um dia, por conta da aproximação, as águas inundariam os trópicos e as montanhas mais altas, e os seres vivos, libertos de seu peso, cresceriam. Os raios cósmicos, por sua vez, tornando-se mais poderosos, induziriam a mutações genéticas, originando novas espécies de animais e plantas e dariam origem a homens gigantescos. A Lua continuaria a se aproximar ainda mais da Terra, até explodir num imenso anel de rochedos, de gelo e de gás que por fim cairão sobre a Terra, realizando o apocalipse 
anunciado. Após essa catástrofe, apenas alguns homens, os mais fortes, os eleitos sobreviverão. Após milênios sem o seu satélite, o planeta Terra verá ainda a sucessão de diversas raças e civilizações provenientes dos gigantes antes de se precipitar sobre o Sol como uma imensa massa de gelo. A nova explosão originará novas criações.

Mas a Lua que vemos hoje não foi a única a ser atraída pelo nosso planeta; houve outras três, que ao caírem sobre a Terra recobriram nosso planeta, fossilizando todos os seres que o habitavam. Ora, essa dinâmica de aproximação da Lua é o que explica, na teoria de Horbiger, a evolução das espécies. De acordo com essa teoria, a aproximação das luas que precederam a nossa em direção à Terra alteraria o nosso peso, o que de fato é verdade. Pois bem, tendo em conta que as criaturas aumentam de tamanho em função do peso que elas podem suportar, o momento em que as luas estão próximas da Terra seria um período de "gigantismo" das espécies. Tais gigantes e suas civilizações possuiriam poderes psíquicos desconhecidos para nós.

Com a queda sobre a Terra da segunda lua e também sob efeito de mutações, os seres começarão a diminuir de tamanho, mas alguns poucos gigantes ainda sobreviverão. Com a queda da terceira lua, formaram-se os homens vulgares que conhecemos hoje, pequenos e menos inteligentes, mas mesmo após esse novo cataclismo alguns descendentes dos primeiros gigantes que teriam conseguido sobreviver estariam aqui para fazerem evoluir os pequenos homens. Por isso teriam sido preservadas, em muitas culturas, a crença de que em um passado muito remoto reis gigantes teriam ensinado aos homens diversas artes como a metalurgia e a agricultura:

“Da Grécia à Polinésia, do Egito ao México e à Escandinávia, todas as tradições dizem que os homens foram iniciados por gigantes. É o período de ouro do terciário, que dura vários milhões de anos durante os quais a civilização moral, espiritual e talvez técnica atinge o seu apogeu sobre o globo"10.

Com a aproximação da terceira lua as águas sobem graças à gravitação do satélite, e os homens que habitam a Terra há mais de 900.000 anos sobem para os cumes das montanhas com seus reis-gigantes e fundam uma nova civilização, que Horbiger e um de seus discípulos ingleses - Bellamy - acreditam ser a Atlântida. Bellamy tenta fundamentar sua crença e a de seu mestre a partir do achado arqueológico, nos Andes, de diversos sedimentos marinhos, indício de que um dia o

\footnotetext{
${ }^{10}$ Pauwels e Bergier, O despertar dos mágicos, p. 271.
} 
nível do mar estivera muito alto. Outro suposto indício da existência desses ancestrais gigantes seriam as mesmas construções em pedra, estátuas gigantescas, supostamente retratos em pedra de seus construtores.

Todas essas civilizações, incluindo os atlantes, possuíam fabulosos poderes psíquicos e, conhecendo os acontecimentos do cosmos, por muito tempo conseguiram adiar, graças a tais poderes, o cataclismo vindouro. Com a queda da terceira lua, essas civilizações desaparecerão. Sendo assim, a Atlântida não teria desaparecido sob uma inundação, mas abandonada pelas águas. Seus navios foram arrastados, suas máquinas avançadas destruídas e reinou a escassez de alimentos. Restou aos reis gigantes retornar às planícies e viverem anos de decadência ao lado dos homens:

"Os gigantes que há milhões de anos habitavam esse mundo, semelhantes aos deuses que povoarão mais tarde as nossas lendas, perderam a sua civilização. Os homens sobre os quais reinavam tornaram-se novamente uns brutos. Essa humanidade caída, atrás dos seus mestres já sem poder, dispersa-se em bandos pelos desertos de lodo" $" 11$.

Notemos que tal narrativa não se adequa com aquela de Platão apenas em parte. Teriam existido duas Atlântidas: uma nos Andes e outra no Atlântico norte, que é aquela a que se refere o filósofo.

Por último, há 12.000 anos, a Terra capta seu quarto satélite, que vem a ser nossa atual Lua. Com isso os mares retrocedem para o equador e têm início as novas eras glaciares nos pólos. É aí que uma segunda civilização de atlantes - menor que a anterior - desaparece tragada pelas águas, dando origem ao relato do dilúvio bíblico. Os gigantes ainda vivos degeneram por conta de seu próprio peso, agora sentido por conta da nova gravidade. A lembrança deles teria sobrevivido nas lendas que conhecemos. Depois disso, surgiram as civilizações humanas, que guardam na memória, expressa em seus mitos, a recordação de um passado fabuloso de deuses e gigantes, como é o caso do Egito, China, Grécia e da civilização judaico-cristã. Mas o tempo de tais civilizações já está no fim. Veremos surgirem novas mutações e a Terra novamente será habitada por gigantes.

De acordo com Pauwels e Bergier:

\footnotetext{
${ }^{11}$ Idem, ibidem, p. 276.
} 
"O que Hitler e os seus amigos encorajam, ao defenderem Horbiger, é uma extraordinária tentativa para restaurar, a partir da ciência ou de uma pseudociência, o espírito das antigas épocas segundo o qual o homem, a sociedade e o universo obedecem às mesmas leis, segundo o qual o movimento das almas e o das estrelas tem correspondências à luta entre o gelo e o fogo, da qual nasceram, morrerão e renascerão os planetas, dá-se também no próprio homem" ${ }^{\prime 2}$.

Boa parte das informações acerca do misticismo de Hitler em $O$ despertar dos mágicos derivam de um livro surgido na França em 1940 - Hitler m'a dit - escrito a partir de supostas conversas de Hitler com Hermann Rauschning, antigo presidente do Senado de Danzig que rompera muito cedo com o nazismo ${ }^{13}$. O objetivo aí é apresentar Hitler como uma espécie de profeta demoníaco de uma nova era de desenvolvimento da humanidade. Em uma dessas conversas, Hitler teria dito a Rauschning que uma "biologia mística" estaria na base das suas inspirações e acreditava que o seu destino podia ser explicado através da ação de "forças ocultas".

De acordo com Rauschning, Hitler ficara muito impressionado com as idéias de Horbiger, e sob tal influência teria lhe dito, no papel de anunciador de uma nova humanidade, que

“A criação não está terminada. O homem atinge nitidamente uma fase de metamorfose. A antiga espécie humana já entrou no estádio do deperecimento e da sobrevivência. A humanidade transpõe um escalão todos os setecentos anos, e o motivo da luta, que só se realizará muito mais tarde, é o advento dos Filhos de Deus. Toda a força criadora se concentrará numa nova espécie. As duas variedades evoluirão rapidamente em discordância. Uma desaparecerá e a outra desenvolver-se-á. Ultrapassará infinitamente o homem atual... Compreende agora o sentido profundo do nosso movimento nacional-socialista? Aquele que só compreende o nacional-socialismo como um movimento político pouco sabe..."14.

Pauwels e Bergier, então, argumentam que o nazismo foi o momento em que a magia se apossou da alavanca do progresso material. A mística nazista, ou melhor, as crenças de Hitler sob a influência das concepções pseudo-científicas de Horbiger iriam influenciar decisões estratégicas na política expansionista do Führer. Na campanha da Rússia, os horbigerianos que se diziam capazes de prever o tempo com uma

\footnotetext{
${ }^{12}$ Idem, ibidem, p. 283.

${ }^{13}$ Os autores citam Rauschning mas não indicam de onde extraíram as citações.

${ }^{14}$ Citado por Pauwels e Bergier, O despertar dos mágicos, p. 289.
} 
antecedência de meses e até de anos anunciavam um inverno suave. Enquanto isso, Hitler estaria convencido de que o frio cederia à passagem dos portadores do fogo. A derrota em Stalingrado iria destruir essa crença.

Contudo, a teoria de Horbiger acerca da criação do universo e do desenvolvimento da humanidade não era a única crença pseudo-científica em pauta na Alemanha nazista. Em 1942, em plena campanha militar - e com a concordância de Goering, Himmler e Hitler - o doutor Heinz Fisher, conhecido por seus trabalhos acerca dos raios infravermelhos, desembarca na ilha báltica de Rügen com aparelhos de radar de última geração. Tratava-se de uma expedição "científica". Por dias os radares apontariam para algum ponto no céu na esperança de que seus dados comprovassem a hipótese de que a Terra seria côncava e não convexa. Na verdade, a expedição de Fisher tinha como objetivo provar cientificamente que a Terra seria oca e que nós habitaríamos o seu interior. O objetivo secundário da expedição, decorrente de seu objetivo principal, era o de descobrir a localização da armada inglesa, o que seria possível caso a Terra fosse mesmo côncava. Em resumo, a idéia era que viveríamos no interior da Terra com o céu - uma massa de gás azul com pontos brilhantes que tomaríamos por estrelas - e o sol no centro ${ }^{15}$.

Tal doutrina tinha sua origem na América, no princípio do século XIX, e na imaginação de Clever Symnes, antigo capitão de infantaria de Ohio, que em 1818 enviara para os membros do Congresso dos Estados Unidos e para os diretores das universidades a seguinte carta:

“Ao mundo inteiro,

Declaro que a Terra é oca e habitável interiormente. Ela contém diversas esferas sólidas, concêntricas, colocadas uma dentro da outra, e é aberta no pólo de 12 a 16 graus. Comprometo-me a demonstrar a realidade do que afirmo e estou pronto a explorar o interior da Terra se o mundo aceitar auxiliar-me no meu empreendimento"16.

$\mathrm{O}$ argumento de Symnes era o de que, sendo tudo oco neste mundo, como os ossos e o caule das plantas, a Terra também deveria sê-lo. Haveria então cinco esferas dispostas uma no interior da outra com aberturas nos pólos, por onde os habitantes de cada um das esferas poderiam se deslocar de uma camada para a outra.

\footnotetext{
${ }^{15}$ Idem, ibidem, p. 299-300.

${ }^{16}$ Citado por Pauwels e Bergier, O despertar dos mágicos, p. 301.
} 
Algum tempo depois, em 1870, outro norte-americano, chamado Cyrus Read Teed, também afirmaria que a Terra, diferentemente daquilo que todos imaginam, seria mesmo oca. Leitor de livros de alquimia, as idéias de Teed provinham de uma vaga "intuição científica" como aquela de Symnes, mas de uma "iluminação" ocorrida durante a leitura do livro de Isaías. Calcado nessa visão, Cyrus Teed criou uma religião e fundou um pequeno jornal chamado A espada de fogo. Em 1894 contava com 4000 discípulos. Pouco tempo depois, em 1913, outro americano, Marshall B. Gardner, publica um trabalho em que tenta provar a crença na Terra oca. No ano seguinte, no início da Primeira Guerra Mundial, o aviador alemão Bender, então prisioneiro na França, tem acesso a alguns exemplares do jornal criado por Teed e regressando à Alemanha dá início ao movimento Hohl Welt Lehre ${ }^{17}$, popularizando na Alemanha a doutrina da Terra oca.

Teve início, assim, a disputa entre os partidários de Bender, que reduzia o universo ao planeta Terra, e os partidários de Horbiger e sua concepção da luta cósmica entre gelo e fogo, com estes últimos ridicularizando os primeiros, ao ponto de pedirem a proibição da divulgação dos livros sobre a Terra oca. Mesmo assim, as idéias de Bender - que eram apoiadas por Goering - deram origem, como vimos, à expedição de Fisher à ilha de Rügen, expedição esta que não conseguiu provar a Hohl Welt Lehre. Mas antes dessa expedição, afirma-nos Pauwels e Bergier, fôra pedida a arbitragem de Hitler, que teria respondido: "Não temos a menor necessidade de uma concepção de mundo coerente". Ou seja, tanto Horbiger quanto Bender poderiam estar corretos, desde que a ciência judaico-cristã do resto do mundo estivesse errada. Mas após a expedição de Fisher, a Hohl Welt Lehre perdeu seu prestígio e Bender foi enviado para a morte em um campo de concentração. A "ciência nórdica" vencera de qualquer jeito, mas sob a forma da luta entre o gelo e o fogo.

Mas havia outras coisas no subterrâneo dessas crenças da ciência nórdica. Na Alemanha, desde o século XIX, proliferavam as seitas místicas, e dentre elas a Sociedade Thule. De acordo com Pauwels e Bergier, a lenda de Thule remontaria às origens do germanismo e dizia respeito a uma ilha supostamente desaparecida em algum lugar do extremo norte e que, tal como a lendária Atlântida, teria vivido ali uma civilização de seres extraordinários. Thule seria um centro mágico, reservatório de energias que dariam aos iniciados da Alemanha os poderes necessários para fazerem

\footnotetext{
${ }^{17}$ Algo parecido com "A doutrina da Terra oca" ou "A ciência da Terra oca".
} 
desta a nação da humanidade futura. Tal lenda, por sua vez, remontaria a uma antiga lenda tibetana que falava da existência, no deserto de Gobi, de uma grande civilização que fôra destruída por uma suposta catástrofe atômica que teria transformado a região em um deserto. Alguns sobreviventes dessa hecatombe teriam emigrado em direção ao extremo norte da Europa. Thor, o deus nórdico do trovão, seria um dos heróis dessa migração. A lenda aparece também em Le Roi du Monde ("O rei do mundo") de René Guenon, que nos informa que os mestres dessa civilização teriam se instalado em um conjunto de cavernas sob o Himalaia. Chegando ao centro dessas cavernas, os grupos dividiram-se em dois: um teria seguido pela "via da mão direita" e outro pela "via da mão esquerda". O primeiro grupo fundaria Agarthi, lugar de contemplação onde reinava o bem e cujos habitantes pregavam a não-participação no mundo. O segundo grupo teria fundado Schamballah, cidade de violência e poder, cujas forças comandariam os elementos e as massas humanas, e "aos magos condutores de povos seria possível fazer um pacto com Schamballah, mediante juramentos e sacrifícios". Os iniciados da Sociedade Thule acreditavam que esses emigrados de Gobi teriam dado origem à raça fundamental da humanidade - a ariana ${ }^{18}$.

Pauwels e Bergier concluem daí o interesse do jovem general e geógrafo Karl Haushofer, supostamente membro da Thule, pela conquista de toda a Europa oriental, Turquestão, Pamir, Gobi e Tibete. Tal contato do Reich com o Tibete explicaria o porquê de, na tomada de Berlim, os russos terem encontrado entre os cadáveres diversos soldados da raça himalaia vestindo o uniforme alemão. A chave capaz de decifrar esse mistério que tanto impressionou a tropa russa pode ser encontrada na sociedade Ahnenerbe, organização encarregada do estudo da "herança ancestral". Fundada por Frederico Hielscher, a Ahnenerbe tinha como objetivo investigar as origens e a herança da raça indo-germânica, missão esta que conduziu os cientistas alemães a contatos com o oriente, sobretudo com o Tibete. Em 1935, Himmler converteu a Ahnenerbe, que até então era uma sociedade privada, em uma organização oficial sob o comando das $\mathrm{SS}^{19}$. O que não deve causar surpresa se considerarmos que a Ordem Negra - alusão ao uniforme negro das SS - representaria uma verdadeira ordem religiosa hierarquizada conforme o modelo da Companhia de Jesus de Inácio de Loyola, organização sobre a qual se assentaria a nova raça de senhores.

\footnotetext{
${ }^{18}$ Idem, ibidem, p. 315.

${ }^{19}$ Idem, ibidem, p. 326.
} 
A partir do clássico "O despertar dos mágicos", a década de 1960 viu proliferar na Inglaterra, França e EUA livros sobre "misteriosofia" nazista, e a maior parte deles cita Pauwels e Bergier como fonte. Em 1971, novamente na França, Jean-Michel Angebert publica Hitler et la tradicion cathare, que em Portugal será traduzido com o título um tanto infeliz de Hitler e as religiões da suástica. Jean Angebert, senegalês nascido em Dacar e especialista em simbolismo e história regional, parece ter conhecido Michel Angebert em Aix-en-Provence, onde ambos realizaram seus estudos superiores. Apesar de dividirem o mesmo sobrenome - Angebert - parece não haver entre eles qualquer parentesco. Jean Angebert é na verdade Jean Angeline, e Michel Angebert chama-se de fato Michel Berttrand. O sobrenome Angebert, como é fácil notar, foi formado a partir de seus sobrenomes verdadeiros.

Nascido em Carcassona, Michel Angebert cresceu em Béziers, centro do catarismo, notável coincidência que este especialista em história das religiões irá explorar, junto com Jean Angebert, ao tentar vincular a ideologia nazista a essa religião herética que se espalhou, no século XI, pelo norte da Itália e sul da França.

Os autores retomam, freqüentemente, o trabalho seminal de Pauwels e Bergier, mas apontam que

"Bergier e Pauwels cometeram, no entanto, um erro de filiação na tradição a que o nazismo se ligava: havia, claro, uma corrente oriental nessa tradição, mas tal corrente veio diluir-se numa corrente principal, verdadeiramente ocidental, que, para simplificar, classificaremos de corrente graálica hiperbórea..."20.

Com isso, os autores tentam deslocar o centro das influências sobre os mistérios nazistas do oriente, sobretudo Índia e Tibete, para a Europa. Para eles, há uma evidente ligação entre o maniqueísmo hitlerista e o maniqueísmo cátaro dos dois mundos opostos representados pela luz e pelas trevas. Ora, que a ideologia nazista era mesmo maniqueísta, quanto a isso não pairam quaisquer dúvidas, mas daí à afirmação de que tal dualismo dever-se-ia à inspiração profética da doutrina herética de Manés repescada pela heresia albigense é algo bem mais difícil de aceitarmos que a filiação do nazismo às correntes orientalistas.

Os cátaros (de Kétzer: puro), surgiram no ocidente por volta do século $\mathrm{X}$ e denunciavam a corrupção do clero católico, afeito à luxúria e apegado aos bens

\footnotetext{
${ }^{20}$ Angebert, Jean-Michel. Hitler e as religiões da suástica, p. 16. Grifo nosso.
} 
materiais. Contra isso, os albigenses (nome dado aos cátaros no Languedoc) pregavam a simplicidade, a abstinência sexual e o vegetarianismo. Angebert aponta que

"Esta crença tem por corolário que a alma, para atingir a perfeição, deve ser purificada da sujidade material e do contato com a carne. O ideal é portanto a castidade, que conduz à salvação. Todavia, como tal doutrina implicava uma disciplina muito rigorosa, a massa dos crentes não era obrigada a praticá-la estritamente. O ascetismo restringia-se aos perfeitos, pequena elite de sábios capazes de receber a iluminação do conhecimento" $^{, 21}$.

Perseguidos pela igreja, os cátaros encontraram no castelo Montségur, nos Pirineus, que estava em ruínas, uma fortaleza em caso de ataque. A cidadela, reconstruída graças a aquiescência e ao auxílio dos senhores da região, converteu-se no centro espiritual da seita no início do século XIII, resistindo por quatro décadas a seguidas investidas. Mas, em 1244, o castelo sitiado foi tomado e 200 cátaros, dentre os quais cinqüenta "perfeitos", preferiram morrer atirando-se em uma pira ardente a renunciarem a suas crenças religiosas.

Pois bem, é nessa altura que a "misteriosofia" de Angebert cruzará com Hitler e o nazismo. Os autores nos informam que, de acordo com os documentos da Inquisição, quatro albigenses teriam conseguido fugir para as montanhas no dia anterior à capitulação, levando consigo um objeto sagrado que seria - pasmem - o santo Graal. Ainda segundo Angebert, em 1931, Otto Rahn, um especialista em catarismo, teria sido enviado pelos líderes nazistas ao refúgio da heresia albigense para investigar se o Graal encontrava-se ainda na região de Montségur. Após algumas viagens de pesquisa, Otto Rahn publica dois livros que fariam sucesso na Alemanha: A cruzada contra o Graal e A corte de Lúcifer na Europa. Os livros, é claro, não indicam a localização do tesouro cátaro, apenas discutem o tema e levantam hipóteses, mas Angebert está certo de que o Graal teria sido encontrado nessas expedições, como fica claro no trecho a seguir:

"O conjunto de acontecimentos, convergindo sempre sobre o Graal e Montségur, parece confirmar que o Graal foi de facto descoberto e transportado para a Alemanha por SS agindo sob a ordem de Himmler; o Reichsführer estaria muito bem informado sobre a provável presença do Graal em Montségur ou na região vizinha:

\footnotetext{
${ }^{21}$ Idem, ibidem, p. 45.
} 
convém não esquecer que o grão-mestre da Ordem Negra era um apaixonado por toda a Idade Média germânica. Pode mesmo acrescentar-se que era uma paixão obsessiva”,22.

Quanto à obsessão de Himmler (ou mesmo de Hitler) pela idade média, isso é um fato notório, a começar pela reforma da fortaleza de Wewelsburg - que em muitos aspectos pitorescos lembrava o rei Arthur e os cavaleiros da távola redonda - para o uso da cúpula das SS. Entretanto, supor que a lenda do Graal seria verdadeira e que os nazistas o teriam encontrado faz parte da mesma metodologia que anima os ocultistas em todas as épocas: o mau hábito de tomar as lendas antigas como realidades ocorridas em um tempo remoto. Resta saber se Angebert está deduzindo tudo isso de sua própria imaginação ou se, de fato, os nazistas chegaram mesmo a crer na realidade dessa lenda a ponto de ocuparem seus cientistas nessa busca.

De qualquer forma, a lenda - não podemos deixar de notar - será interpretada muito de acordo com os interesses racistas da época: “os filósofos nacional-socialistas não deixaram de dar hipóteses de que o Graal seria uma mensagem em escrita rúnica antiga, e que constituiria o último legado do reino boreal de Thule"23. A ilha Hiperbórea, que supostamente teria existido onde hoje se situam a Islândia e a Groenlândia e que teria desaparecido após um cataclismo, representaria, ainda mais que a Atlântida, a origem de todos os segredos do mundo, e sua capital seria Thule. Lembremo-nos de que a importância dessas crenças, tal como é o caso do mito da Atlântida, reside no seu poder de confirmar algumas teorias racistas, movimento este que Angebert reconhece bem:

“(...) para estas [seitas racistas], o fim da Atlântida deve-se a uma mistura racial, a uma corrupção do sangue da raça pura dos Atlantas brancos ao cruzar-se com as raças ‘demoníacas' e ‘inferiores' do tipo asiático-semita.

Compreende-se desde logo o interesse que os ocultistas (cuja organização possuía ramificações no mundo inteiro) dedicaram ao mito da Atlântida, dado que ele estabelecia uma continuidade histórica da raça branca, assegurando-lhe um supremacia material e espiritual sobre todas as outras raças desde tempos imemoriais" ${ }^{24}$.

Apesar da tentativa frustrada de vincular o nazismo ao catarismo, Angebert não deixa de insistir nas vinculações deste com as seitas secretas e com a teosofia.

\footnotetext{
${ }^{22}$ Idem, ibidem, p. 67.

${ }^{23}$ Idem, ibidem, p. 73.

${ }^{24}$ Idem, ibidem, p. 87.
} 
Entretanto, sua análise não traz nada que já não estivesse presente em Pauwels e Bergier, mas esclarece alguns pontos.

Após o final da Primeira Guerra Mundial, proliferavam na Alemanha sociedades secretas como a Sociedade do Vril e a Thulegesellschaft. Na origem da Sociedade do Vril - ou Loja Luminosa - encontramos Louis Jacolliot (1837-1890), cujas idéias foram influenciadas por esoteristas como Swedenborg e o alquimista Jacob Boehme e que, tendo vivido boa parte de sua vida na Ásia, particularmente na Índia, Jacolliot incorporará à sua doutrina elementos orientalistas. Para ele, existiria no universo uma imensa reserva de energia da qual utilizaríamos somente uma fração ínfima, energia essa responsável por toda a ação humana e que ele denominava Vril. Adoradores do sol, seus templos seriam decorados com motivos dominados pela cruz gamada. A sociedade do Vril teria sido fundada na Alemanha no início do século $\mathrm{XX}$, mantendo laços estreitos com os círculos teosóficos e com a Golden Dawn britânica e dela faria parte Karl Haushofer, principal geopolítico do nazismo ${ }^{25}$. Segundo Angebert, existiria na Índia uma seita esotérica com o mesmo nome e que ainda há poucos anos contava com dois milhões de adeptos.

Quanto ao grupo Thule - Thulegesellschaft - ele teria sido criado em agosto de 1918 pelo barão von Sebottendorf como uma ramificação de outra sociedade secreta conhecida como Germanenorden, a Ordem dos Germanos, fundada em 1912. O barão von Sebottendorf, outro orientalista, será o responsável pela compra do jornal Völkischer Beobachter, em nome da Thulegesellschaft, que converter-se-á no jornal oficial do partido nazista e principal veículo de difusão de idéias racistas. Tal inclinação racista já podia ser notada no estatuto da Ordem dos Germanos, também conhecida como "Aliança para o Dever e Conhecimento da Arte Original Alemã”, que só aceitava como membro um alemão capaz de provar a pureza de seu sangue até a terceira geração. Nas publicações da ordem destacava-se a suástica e o símbolo do deus nórdico Wotan. E quanto à Thulegesellschaft, que no futuro absorverá a Ordem dos Germanos, já sabemos que seu nome é uma alusão ao reino do continente hiperbóreo.

Contudo, a informação mais importante que surge em Hitler et la tradition cathare diz respeito à doutrina do gelo eterno de Horbiger. A esse respeito, Angebert cita um livro de Hitler quase impossível de ser encontrado hoje - Libres propos sur la guerre et la paix - por algum motivo ignorado por Pauwels e Bergier e que prova de

\footnotetext{
${ }^{25}$ Idem, ibidem, p. 217.
} 
forma definitiva a influência da teoria horbigeriana sobre a ciência nazista. As palavras são do próprio Führer:

"Estou bastante inclinado a aceitar as teorias cósmicas de Horbiger. De facto, não se pode excluir a possibilidade de que dez mil anos antes da nossa era se tenha produzido uma interferência na Terra e na Lua que teria determinado à Lua a sua actual órbita. É possível igualmente que a Terra tenha atraído para si a atmosfera que até então pertencia à Lua, o que teria transformado absolutamente as condições de vida sobre o nosso planeta", 26 .

Logo em seguida, Hitler expressa a sua admiração por Horbiger comparando-o a Ptolomeu e Copérnico:

"Era um grande progresso, na época de Ptolomeu, dizer que a Terra era uma esfera e que as estrelas gravitavam à volta dela. Depois disso, não se cessou de progredir nessa via. Copérnico primeiro. Copérnico é por sua vez largamente ultrapassado, e sempre assim será. Nos nossos dias, Horbiger deu um novo passo em frente...,"27.

Outra importante informação, se for possível dar crédito a Angebert, diz respeito à grade curricular a que estavam submetidas as escolas alemãs da época. O programa de História tinha início com o estudo da lenda hiperbórea, prosseguia com o estudo aprofundado da idade média e era concluído com o estudo da história contemporânea, do partido nacional-socialista e de seu chefe Adolf Hitler. Nesse programa, a Biologia era considerada sob um prisma racista que incluía o estudo das obras de Gobineau, H. S. Chamberlain e Alfred Rosenberg. Os estudos em História pretendiam provar que após o desaparecimento do continente hiperbóreo três raças haviam sobrevivido: os Ases (antepassados dos atuais Arianos), os Ciganos e os Hebreus. E quanto aos hebreus,

“O paralelo entre a raça judaica e a raça ariana era constantemente feito: o objectivo das duas raças identificava-se, ou seja, a dominação universal pela purificação da raça e seu desenvolvimento messiânico no quadro de uma teocracia militante e da conservação absoluta dos costumes ancestrais. Os educadores SS, supremamente cultos e totalmente fanatizados, ensinavam a história da raça hebraica, frisando como ela

\footnotetext{
${ }^{26}$ Hitler, A. Libres propos. Paris, Flamarion, 1952, tomo I, p. 243. Citado por Angebert, J. M., Hitler e as religiões da suástica, p. 245.

${ }^{27}$ Idem, ibidem, p. 247.
} 
sobreviveu e progrediu apesar de dois mil anos de perseguições ininterruptas; pertencia portanto à raça ariana seguir o mesmo exemplo e exterminar imediatamente esses perigosos concorrentes à supremacia planetária (...)”28.

${ }^{28}$ Idem, ibidem, p. 279. 


\section{CAPÍTULO V: AS VERDADEIRAS RAÍSES ESOTÉRICAS DO III REICH}

\author{
"Para os historiadores acostumados a considerar \\ fatos concretos, causas e propósitos racionais, este \\ submundo de fantasia poderá talvez decepcioná-los. \\ Protestarão que as transformações históricas e \\ políticas se baseiam em interesses materiais \\ verificáveis. Sem embargo, as fantasias podem \\ adquirir um status causal, uma vez \\ institucionalizadas em crenças, em valores e em \\ grupos sociais."
}

(Nicholas Goodrick-Clarke)

\section{O evolucionismo místico de H.P. Blavatsky e a origem do mal}

Filha de um oficial do exército e de uma romancista popular, Helena foi oferecida em casamento ao general czarista e vice-governador provincial Nikifov Blavatsky, de quem herdaria somente o nome. Três meses depois, Helena Blavatsky abandona o marido e foge para Constantinopla. Nesse momento, têm início as especulações, os fatos imprecisos, as viagens supostas que darão forma ao mito em torno da mais importante ocultista do século XIX.

Conta a lenda que Blavatsky teria viajado para o oriente, Ásia Central, Índia, África, América Central e do Sul, Europa e Estados Unidos. Ao longo dessas peregrinações, ela teria sido "iniciada" em uma seita muçulmana do Oriente Médio (os drusos), estudado os rituais dos dervixes e assistido a secretos rituais vudus, além de estudar a magia yamabushi (uma seita japonesa), conhecer as ruínas maias e a pirâmide de Quéops. Mas nada que se comparasse aos sete anos que diz ter passado em um vale oculto na cordilheira do Himalaia, no Tibete, onde teria sido iniciada por uma comunidade de mestres espirituais que lhe ensinaram uma antiga sabedoria que revelava muitos dos mistérios do universo ${ }^{1}$.

Entretanto, a vida de Blavatsky parece ter sido bem mais modesta que essa lenda por ela inventada. Conta-se que muito provavelmente ela nunca esteve no Tibete, que ainda hoje pode ser considerada uma das regiões mais inacessíveis do mundo e que desde 1792 estava com as fronteiras fechadas aos estrangeiros. Além do mais, nunca foi

\footnotetext{
${ }^{1}$ Mistérios do desconhecido: seitas secretas, p. 129.
} 
possível, nem para o mais ardente admirador de Blavatsky, encaixar esses supostos sete anos no Tibete na biografia de sua mestre. O mais provável é que ela tenha saído de Constantinopla, ido até o Egito e de lá seguido para Londres, onde teria se casado com um cantor de ópera húngaro de meia-idade. É possível que ela tenha se casado três ou quatro vezes sem ter se divorciado do primeiro marido, sendo que um desses casamentos teria originado uma criança com deficiência física (um menino corcunda) de nome Yuri, que teria morrido ainda na infância, mas que ela afirmava ser adotado ${ }^{2}$.

Aparecendo aqui e desaparecendo ali, em 1871 Blavatsky retornou ao Cairo, onde segundo ela teria estudado ocultismo em uma ordem egípcia tão antiga e misteriosa que ninguém conhecia. Após algumas fraudes como médium e a fundação de uma sociedade espírita que não conseguia arregimentar seguidores, ela parte para a Europa, surgindo na França em 1837 onde, seguindo os conselhos de seus mestres espirituais, decide zarpar para os Estados Unidos.

No ano seguinte, em 1874, ela conhece aquele que viria ser seu adepto e parceiro por toda a vida: Henry Steel Olcott. Jornalista autônomo, veterano da Guerra Civil, advogado e pesquisador da paranormalidade, o coronel Olcott conheceu Blavatsky em Vermont, onde estava cobrindo algumas sessões espíritas na fazenda de um lavrador e que vinham atraindo muitos crentes e curiosos. Algum tempo depois, os dois já estavam vivendo juntos em um apartamento em Manhattan onde, aos domingos, o casal organizava encontros onde se agrupavam espíritas, maçons e rosa-cruzes. A partir dessas reuniões, Olcott sugeriu a criação de uma sociedade que seria a origem da futura Sociedade Teosófica. E foi exatamente nessa época que Blavatsky começou a escrever seu Ísis Desvelada, supostamente sob inspiração de seus mestres espirituais. O livro, publicado em 1877, em dois volumes que totalizavam quase 1300 páginas, teve sua primeira edição esgotada em dez dias. O ataque da crítica foi imediato, e as denúncias mais importantes diziam respeito ao plágio de centenas de trechos provenientes de escritores cabalistas, maçônicos e rosa-cruzes, dentre outros ${ }^{3}$.

Graças ao sucesso de Ísis desvelada, a sociedade teosófica estabeleceu lojas em Londres e Bombaim. Aproveitando o declínio dos negócios mediúnicos em Nova York e a obsessão de Blavatsky pela Índia, esta parte com Olcott em 1878 para Bombaim, onde a teosofia deixou-se influenciar pela doutrina indiana da reencarnação. Os dois mestres espirituais de Blavatsky continuavam a visitá-la, mesmo na Índia. O mestre

\footnotetext{
${ }^{2}$ Idem, ibidem, p. 129.

${ }^{3}$ Idem, ibidem, p. 131.
} 
Moryana, membro da casta guerreira indiana, tinha cerca de 125 anos de idade quando se apresentou a Blavatsky em 1850-1851 em Londres, já o mestre Koot Hoomi apareceu-lhe em um sonho em 1870. Desnecessário dizer que a existência de tais mestres sempre foi muito controvertida: ninguém nunca chegou a vê-los, mas muitos admitiam a existência corpórea desses Mahatmas. Eles se comunicavam com Blavatsky, geralmente através de cartas que surgiam em lugares inesperados, muitas vezes caídas do teto. Tais aparições chegaram a convencer muitos de seus admiradores, como foi o caso de Alfred Percy Sinnet, editor do mais importante jornal britânico na Índia, que se tornou um importante colaborador da sociedade teosófica e escreveria uma biografia de Blavatsky.

Em 1884, no auge de seu sucesso, ela decide visitar a Inglaterra, deixando a loja da Índia sob os cuidados de dois empregados, Emma e Alexis Coulomb, que rapidamente se indispuseram com membros importantes da sociedade teosófica, conflito que culminou na demissão de ambos. Em retaliação, Emma procurou uma revista dirigida por missionários protestantes e denunciou todos os truques de mágica de Blavatsky, incluindo os impressionantes fenômenos das cartas que caiam do teto: as cartas provenientes do "correio astral" haviam sido jogadas por uma fenda no teto. A acusada retornou às pressas para a Índia ameaçando processar Emma Coulomb, mas foi dissuadida por seu advogado. Não havia mais como salvar a sociedade teosófica na Índia e Blavatsky teve que retornar para a Europa, nunca mais regressando à Índia.

Entretanto, o pesadelo da sociedade teosófica estava apenas começando. Ao chegarem a Londres, Blavatsky e Olcott foram procurados pela recém-criada Sociedade de Pesquisas Psíquicas (SPR), cuja intenção era investigar os "fenômenos" a que Blavatsky aludia. O trabalho da SPR era francamente favorável à teosofia, mas sua orientação mudou com o relatório de um de seus inspetores que havia sido enviado à Índia como parte das investigações. O resultado foi a confirmação de todas as denúncias feitas por Emma Coulomb, além de algumas novas. O relatório de Richard Hodgson causou um escândalo internacional, mas não conseguiu calar Blavatsky, que mesmo doente começou a escrever sua maior obra, A doutrina secreta - que pretendia dissolver alguns mal-entendidos "teóricos" suscitados pelo seu Ísis desvelada - em vários volumes, totalizando mais de 1500 páginas.

De acordo com Blavatsky, o livro teria sido escrito a partir de revelações recolhidas em um livro muito antigo, chamado livro do Dzyan, "um manuscrito arcaico, uma coleção de folhas de palma que se tornaram impermeáveis à água e imunes à ação 
do fogo e do ar, por algum processo específico desconhecido" ${ }^{4}$. Esse livro, revelado ao guardiões da Ásia Central, seria o mais antigo livro do mundo, do qual teriam derivado todos os demais livros sagrados como o Shu-king (primitiva bíblia chinesa) e os Purânas da Índia. Segundo a tradição, o livro do Dzyan teria sido escrito em senzar, uma língua secreta dos sacerdotes e que vinha sendo passado aos iniciados desde a primeira raça. Desnecessário dizer que não existem registros históricos de tal livro, o que a própria Blavatsky reconhece, ao afirmar que as Estâncias do Dzyan "representam

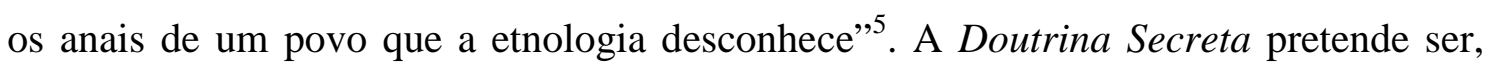
sem qualquer modéstia, como indica o subtítulo, uma "síntese da ciência, da religião e da filosofia".

De acordo com a Doutrina Secreta, a história humana teria se desenvolvido ao longo de sete raças-raiz. A primeira raça-raiz, conhecida como os "nascidos por si mesmos", foram os habitantes do primeiro continente, chamado de "terra sagrada e imperecível". A segunda raça-raiz foi aquela dos "nascidos do suor" ou os "sem ossos". Essa raça habitou um continente que se estendia ao sul e ao leste do pólo norte e que Blavatsky supõe ter mesmo existido tal como é descrito na mitologia grega, ou seja, a região para onde o deus Apolo ia viajar todos os anos. Desta segunda raça procedeu a terceira raça-raiz, a raça dos "duplos" (andróginos) que, diferente das primeiras duas raças (que se reproduziam por meios espirituais), já se reproduziam de forma sexuada. Tal raça teria vivido em um continente que se estendia de Madagascar ao Ceilão e Sumatra e teria submergido sobre as águas. Tal continente foi batizado por P. L. Sclater como "Lemúria" e supunha-se que tivesse realmente existido. A quarta raça foi a lendária raça dos atlantes, habitantes do continente desaparecido a que se referira Platão. Atualmente a Terra é habitada pela quinta raça-raiz, a raça ariana, sendo seu continente a Europa.

Quanto à gênese do cosmos, Blavatsky supõe, sempre seguindo sua lógica obsessiva quanto ao número sete, que cada um dos planetas conhecidos ou ainda desconhecidos passa por sete ciclos ou rondas. Ou seja, existem duas cadeias paralelas de desenvolvimento, um ciclo das raças que vai de 1 a 7 e um ciclo ou ronda dos planetas que vai, por exemplo, de A até G. Encontramo-nos em D, a quarta ronda, de acordo com a cosmogênese teosófica e na quinta raça-raiz segundo sua antropogênese. De acordo com Blavatsky, a humanidade na Terra

\footnotetext{
${ }^{4}$ Blavatsky, H. P. A doutrina secreta, volume I, p. 71.

${ }^{5}$ Idem, ibidem, p. 60.
} 
"só se desenvolve plenamente na quarta Ronda - que é a nossa Ronda atual. Até esse quarto ciclo de vida, dá-se-lhe tal nome de "Humanidade" unicamente por falta de outro melhor. Assim como a lagarta se converte em crisálida e esta em borboleta, assim o homem, ou melhor, o que mais tarde vem a ser o homem, passa através de todas as formas e reinos durante a Primeira Ronda, e através de todas as formas humanas durante as duas Rondas seguintes. Ao chegar à Terra, no princípio da Quarta, na presente série de Ciclos de Vida e de Raças, o Homem é a primeira forma animada que aparece nela, pois foi precedido somente pelos reinos mineral e vegetal, devendo ainda este último desenvolver-se e continuar sua evolução ulterior por intermédio do homem", .

O tema todo é bastante confuso e se complica ainda mais quando pensamos na "materialidade" das raças e dos ciclos dos planetas. No caso do planeta Terra, em suas três primeiras Rondas há uma "descida na matéria", ou seja, nas três primeiras Rondas a Terra se "materializa" adquirindo estabilidade e consistência até tornar-se efetivamente visível na quarta Ronda. A partir daí ela segue uma trilha ascendente, onde vai se "desmaterializando", se "espiritualizando", e retornando à sua forma etérea nas rondas de 5 a 7.

O mesmo acontece com as raças. Blavatsky afirma que os atlantes "foram realmente a Raça puramente humana e terrestre", sendo aqueles que os precederam "mais divinos e etéreos do que humanos e sólidos". Tal relato não deixa de nos surpreender se considerarmos que a raça imediatamente anterior aos atlantes (os hermafroditas lemurianos da terceira raça) sejam agora considerados "etéreos". Porém, o que mais importa é notarmos que na evolução das raças-raiz há, como no caso dos planetas, uma "descida na matéria" que Blavatsky entende como uma evolução da natureza física (partindo de formas mais sutis, espirituais, etéreas) e intelectual com um conseqüente retrocesso da espiritualidade, da primeira raça até a metade da terceira. A partir daí ocorreria uma reversão, com o decréscimo da materialidade e da inteligência meramente cerebral conduzindo a um aumento da espiritualidade. Nossa quinta raça estaria, portanto, já na fase ascendente, rumo a uma maior espiritualidade. Aqui, um novo problema de incoerência interna: a raça que nos precedeu, os atlantes, que também já estariam na ascendente, porém menos evoluídos na espiritualidade que nós da quinta raça (lembremos de que o ponto de mutação se dá após a metade da terceira raça) é

\footnotetext{
${ }^{6}$ Blavatsky, H. P. A doutrina secreta, v. I, p. 203.

${ }^{7}$ Idem, ibidem, p. 289.
} 
constantemente apresentada como sendo portadora de "poderes psíquicos" por nós desconhecidos e serem uma civilização muito avançada, o que não faria qualquer sentido sendo que eles estariam mais submetidos que nós à matéria. Mas exigir coerência de um trabalho como A doutrina secreta seria perda de tempo: essas incoerências são as menores dentre as suas bizarrices.

O mais surpreendente na antropogênese jaz na rejeição da evolução das espécies. Segundo Blavatsky, o ocultismo repudia a idéia de que o homem possuiria um ancestral comum com os macacos. Para ela, parte da quarta raça teria procriado com fêmeas de outra espécie - animal ou semi-humana - e os seres híbridos resultantes dessa união procriaram também dando origem aos atuais símios antropóides. Em outro momento, ela aponta a terceira raça do primeiro período atlante como a origem dos símios $^{8}$. Nas palavras da autora:

“Moralmente irresponsáveis, os 'homens' da terceira raça, mantendo relações antinaturais com espécies animais inferiores a eles, deram origem àquele 'elo perdido' que, em épocas posteriores (no período terciário somente), veio a ser o remoto antepassado do verdadeiro símio, tal qual o conhecemos hoje na família pitecóide"”.

Blavatsky também nos informa que os atlantes seriam semelhantes a "símios gigantescos”, mas mesmo assim era um ser que falava e pensava e sua civilização teria alcançado um grau de civilização superior ao nosso ${ }^{10}$. A pergunta que agora se coloca é a seguinte: de onde vieram essas supostas espécies de animais inferiores ou semihumanos? Aqui ela cita o Livro de Dzyan:

“Durante o período inicial da Quarta Evolução do homem, o reino humano ramificou-se em várias direções diferentes. A forma exterior de seus primeiros exemplares não era uniforme, pois os veículos [as cascas externas ovóides, nas quais se processava a gestação do futuro homem plenamente físico], antes de se endurecerem, foram com freqüência corrompidas por enormes animais, de espécies hoje desconhecidas, resultantes de tentativas e esforços da natureza. Daí surgiram raças intermediárias de monstros, meio-homens, meio-animais" $" 11$.

\footnotetext{
8 Talvez a explicação para isso esteja naquilo a que ela se refere como dinastia lêmuro-atlante, remanescentes dessas duas raças raízes.

${ }^{9}$ Blavatsky, H. P. A doutrina secreta, v. I, p. 231.

${ }^{10}$ Idem, ibidem, p. 232.

${ }^{11}$ Blavatsky, H. P. A doutrina secreta, v. III, p. 210. O itálico e os colchetes são da própria Blavatsky.
} 
Blavatsky reconhece a objeção dos biólogos do seu tempo, que afirmavam ser impossível a procriação entre espécies diferentes, mas responde que isso seria possível, pois acontecera quando o homem físico acabara de surgir. E avança em sua teoria ao criticar os naturalistas que argumentavam que todas as raças humanas poderiam se cruzar umas com as outras. Ou seja, ela admite que, antes do homem se constituir em sua forma física atual, mais densa, era possível o cruzamento entre raças diferentes, o que seria impossível agora. Mas havia exceções a essa impossibilidade. Então ela cita um caso que Darwin analisara de esterilização em massa em uma tribo da Tasmânia, criticando a tentativa do naturalista de buscar explicação para isso em uma mudança nos hábitos alimentares. "Para o ocultista é coisa evidente", afirma: o cruzamento de europeus com as mulheres tasmânias, que representariam a progênie de "monstros" sem alma e sem mente, teria ocasionado a referida esterilidade. Não por conta de uma lei fisiológica, mas por força de uma lei de evolução cármica ${ }^{12}$. Em nota, ela tenta esclarecer o que entende por "sem alma", explicando não pretender negar uma alma aos animais (dos mais humildes aos mais elevados), mas apenas indicar tratar-se aqui somente de uma Alma-Ego consciente que teria sobrevivido e reencarnado em outro homem. O soneto teria ficado menos pior sem essa emenda incompreensível aos nãoiniciados.

Em resumo, dentre todos os mamíferos o homem teria sido o primeiro a aparecer e teria sido o antepassado indireto do macaco a partir de um decaimento moral e físico, antecedido por cruzamentos antinaturais. Como resultado, surgiram espécimes humanos inferiores que em seguida, ao se reproduzirem, originaram uma espécie que se desenvolveu dando origem, muitos séculos depois, aos símios que conhecemos.

Dando prosseguimento ao desenvolvimento de sua lógica racial, Blavatsky, ao discutir o desenvolvimento da linguagem, aponta o sânscrito como a primeira língua da quinta raça-raiz, hoje a língua que guarda os mistérios dos iniciados. Sua conclusão é a de que os semitas seriam os arianos mais recentes, espiritualmente degenerados, porém materialmente aperfeiçoados. A essa categoria, aponta, "pertencem todos os judeus e árabes"13, e em seguida desenvolve sua história dos povos semitas:

“Os primeiros [judeus] representavam uma tribo descendente dos chandalas da Índia - os 'fora de casta' -, muitos deles ex-brâmanes, que buscaram refúgio na

\footnotetext{
${ }^{12}$ Idem, ibidem, p. 214.

${ }^{13}$ Idem, ibidem, p. 218 . O grifo é nosso.
} 
Caldéia, na Cindia e em Ária (Irã), e que efetivamente haviam nascido do pai A-Brahm (não-brâmane), uns 8.000 anos antes de Cristo. Os outros, os árabes, são descendentes dos arianos que não quiseram ir para a Índia, no tempo da dispersão dos povos, alguns deles permanecendo em suas fronteiras, no Afeganistão e no país de Kabul, assim como nas margens do Oxus, enquanto outros penetraram na Arábia e a invadiram. Mas isto ocorreu quando a África se levantou como um continente" ${ }^{, 14}$.

\section{O armanismo: Guido von List e a Armanenschaft (Comunidade Armanista)}

Em 5 de outubro de 1848 nascia, em Viena, no seio de uma família de comerciantes de classe média, aquele que se converteria no principal escritor völkisch e ideólogo do pangermanismo de antes da Primeira Grande Guerra. Guido Karl Anton List, ou Guido von List, como viria a ser conhecido, seguiu a religião dos pais, o catolicismo - religião da maioria dos austríacos - até o início da adolescência, quando um incidente bucólico fez com que o jovem se afastasse da ortodoxia católica. Em um passeio na companhia do pai (Karl Anton List) e de alguns amigos em 1862 às catacumbas da catedral de São Estevão (San Esteban), List fica profundamente impressionado com a atmosfera do local, e aproximando-se de um altar em ruínas jurou que construiria ali, quando crescesse, um templo dedicado ao deus Wotan / Odin. Em suas fantasias adolescentes o labirinto sob a catedral representaria um santuário précristão dedicado ao deus pagão dos antigos germanos.

Os interesses de List restringiam-se, enquanto seu pai estava vivo, a passeios a cavalo, onde admirava a natureza, praticando remo e alpinismo. E foi exatamente em uma dessas excursões na companhia de amigos, em novembro de 1875 que, enquanto remavam pelo Danúbio, List alcançou as ruínas da cidade romana de Carnuntum, onde passaram a noite. De acordo com Goodrick-Clarke, historiador do esoterismo ocidental: "Para List, perdido em suas fantasias, foi a celebração pelo aniversário de número 1500 da vitória tribal germânica sobre os romanos, que ele celebrou com fogo e enterrando nove garrafas formando uma suástica sob o arco da porta pagã"15.

Com a morte de Karl Anton em 1877, List que nutria ambições artísticas, não possuía qualquer vocação para levar adiante os negócios que herdara de seu pai. Afastado do comércio, ele se casa no ano seguinte e passa a viver com a jovem esposa

\footnotetext{
${ }^{14}$ Idem, ibidem, p. 218-219.

${ }^{15}$ Goodrick-Clarke, N. Las oscuras raices del nazismo, p. 59.
} 
anos de privação. Sua nova carreira como jornalista não lhe fornecia os rendimentos necessários para que ele vivesse a vida confortável de seus tempos de adolescência, mas seus interesses em história e literatura, tudo isso enformado por sua paixão nacionalista, logo daria frutos.

Enquanto publicava artigos sobre o cotidiano e os costumes dos camponeses, onde pululavam interpretações muitas vezes fantasiosas sobre as origens pagãs dos movimentos, costumes e lendas locais, List trabalhava em um grande romance, inspirado nas impressões geradas pela excursão de 1875 às ruínas daquela antiga cidade romana. O romance Carnumtum, publicado em 1881, inicia List na profissão de visionário e místico. Inspirado apenas por sua imaginação, como costuma ocorrer com os místicos em todas as épocas, List descreve aí a história longínqua da cidade como se fosse uma incontestável realidade histórica, descrevendo em detalhes - como se ele mesmo tivesse presenciado - a batalha ocorrida entre germanos e romanos que levou à queda das resistências no ano de 375.

De acordo com os relatos de List, esse ataque das tribos Quadi e Marcomanni teria dado início às invasões germanas que levariam ao saque de Roma em 410 e ao colapso do império. Carnuntum representaria assim um marco na história mundial, protagonizado pelos germanos. Esta história enganosa, aponta o historiador GoodrickClarke, teria soado muito atrativa para os nacionalistas da Áustria, já que como bem indicava a novela de List, as tribos da Áustria pré-romana e os reinos bárbaros que lhe sucederam apontavam para uma ocupação nativa e contínua da pátria. Tal continuidade teria sido rompida apenas em dois momentos: pela colonização romana de Pannonia entre os anos 100 e 375 d. C. e logo em seguida pelo advento da cristandade (a "outra Roma”). Com essa última afirmação, List expressava sua aversão ao establishment católico na Áustria, denunciando que "a ordem política do presente e sua principal confissão religiosa demonstravam ser ilegítimas, derivavam da inspiração de um jugo estrangeiro e a supressão da cultura germânica muitos anos antes"16.

Essa obra clarividente de List fez com que ele ficasse conhecido nos círculos völkisch, convertendo-o em uma figura conhecida do movimento pangermânico na Áustria, que buscava uma legitimação de seu descontentamento com o Estado multinacional austríaco. Os trabalhos de List prosseguiram ao longo da década de 1890 com diversas contribuições ao semanário Ostdeutsche Rundschau (Revista da Alemanha

\footnotetext{
${ }^{16}$ Idem, ibidem, p. 61.
} 
Oriental), sempre tratando do passado remoto da Áustria, da mitologia germânica e do folclore. Ao lado de seus sentimentos nacionalistas, crescia também o anti-semitismo, como aponta o ensaio Die Juden als Staat und Nation (Os judeus como estado e nação), publicado na Ostdeutsche Rundschau em fevereiro de 1896.

Anos antes, em 1893, List aborda em uma conferência a existência de um antigo sacerdócio sagrado do culto de Wotan (ou Odin), antigo deus germânico, fé esta que teria sido a religião nacional dos teutônicos. A oposição, como se vê, travava-se sempre contra a Igreja católica em favor de uma religião pagã primordial, como mostram seus posteriores trabalhos de ficção, caso de Jung Diethers Heimkehr (O regresso do jovem Diethers) de 1894, que "conta a história de um jovem teutônico que fôra convertido a força ao cristianismo no século V. A novela termina com o feliz regresso do apóstata à sua religião original, adoradora do Sol"17. A fundação, em 1893, da Literarische Donaugesellschaft (Sociedade Literária do Danúbio), sob a batuta de List, tinha exatamente como objetivo difundir esse tipo de literatura nacionalista e neo-romântica em Viena.

Assim como Richard Wagner, List também pretendia divulgar suas idéias através do drama. E o tema central dessas encenações também eram muito semelhantes: representações sentimentais do passado nacional, com Carnuntum representando para List o mesmo que Bayreuth representara para Wagner. Um produto interessante desse uso do cenário como veículo de suas idéias, aponta Goodrick-Clarke, fôra o panfleto programático A reconstrução de Carnuntum:

\footnotetext{
"Aqui List pedia a reconstrução do anfiteatro romano como cenário ao ar livre para que se fizessem representações que incluiriam a matança de dragões, regatas, competições entre bardos e Thinge (as assembléias anuais alemãs), que levariam o simbolismo do cristianismo a um público mais amplo de pangermanos na Áustria. List chamou ao projeto de uma Nova Carnuntum de uma 'Bayreuth austro-germânica', e era evidente que o exemplo de Richard Wagner lhe havia servido como modelo"18.
}

A partir de seu interesse pelo passado heróico e mitológico dos germanos e tendo em conta as fantasias históricas geradas por esse interesse, a conversão de List ao ocultismo descortinava-se com a força de uma conseqüência lógica. Em 1902, após uma cirurgia de catarata que lhe deixou cego por onze meses, List teve tempo para

\footnotetext{
${ }^{17}$ Idem, ibidem, p. 64.

${ }^{18}$ Idem, ibidem, p. 65.
} 
considerar a origem das runas e da linguagem em um viés francamente ocultista mas que, como acontece com razoável freqüência nesses casos, ele acreditava tratar-se de uma abordagem "científica" revolucionária, tanto que submeteu o manuscrito de um trabalho acerca da protolinguagem dos arianos à Academia Imperial de Ciências de Viena. A academia guardou silêncio sobre essa obra pseudocientífica de lingüística e simbologia alemãs que interpretava por meios ocultistas as letras, os sons das runas e as inscrições antigas. Na década seguinte, essa obra se converteria em uma peça fundamental de suas investigações ocultistas-nacionalistas ${ }^{19}$.

Pouco tempo depois da frustração com a Academia imperial de Ciências, Guido Karl Anton List converte-se em Guido von List. Ao reivindicar o título de nobreza "von", List pretendia assegurar para si uma ascendência que remontasse ao passado mais remoto. Afirmando que seu bisavô, ao ingressar no comércio burguês, teria abandonado seu título de nobreza, List pleiteou na justiça a recuperação do título de sua família apresentando um anel, supostamente utilizado por seu avô e que era o mesmo do cavaleiro Burckhardt von List, que vivera no século XII. Um contemporâneo seu, Lanz von Liebenfels, de que trataremos a seguir, também esboçara pretensões de nobreza que muito possivelmente influenciaram as fantasias de List. O motivo parece ser, no caso de ambos, uma derivação de suas fantasias religiosas que exigia que List (tanto quanto Lanz) se apresentassem como descendentes, logo como representantes legais, dos líderes das antigas tribos germânicas do passado:

\footnotetext{
"Segundo suas leituras sobre o sacerdócio wotanista, List acreditava que esta antiga elite religiosa havia formado a primeira aristocracia da Alemanha tribal. Ao fazer alarde de um título aristocrático (...) List se reassegurava ser um descendente da antiga hierarquia assim como de sua história",20.
}

Ainda por conta do incidente com a Academia Imperial, os seguidores de List decidiram fundar uma sociedade para financiar e publicar as especulações ocultistas de seu mestre. A Sociedade List impulsionou o crescimento da popularidade de List entre os grupos völkisch ao atrair como membros importantes nacionalistas e ocultistas.

Entretanto, apesar de sua imaginação prodigiosa e de seu pioneirismo na interpretação ocultista das runas, List não idealizou sua nova religião a partir do nada. Ele incorporou elementos da teosofia moderna para construir suas fantasias mitológicas.

\footnotetext{
${ }^{19}$ Idem, ibidem, p. 66.

${ }^{20}$ Idem, ibidem, p. 67.
} 
Muitos desses elementos já estavam disponíveis na cultura e a própria teosofia já havia sido impulsionada pelos trabalhos de Blavatsky. Seus trabalhos faziam referência a essa grande personalidade da teosofia, bem como a William Scott-Elliot, autor de The lost Lemuria, que como bem indica o título do trabalho, trata de continentes e civilizações desaparecidas. Dada a influência de Blavatsky, "List já não chamava aos antigos nativos de 'germanos' e não falava de 'povo', mas de 'ario-germanos' e de 'raça', para identificá-los com a quinta raiz racial do esquema etnológico proposto por Blavatsky”"21.

Outra fonte de influência apontava para os escritos de Max Ferdinand Sebaldt von Werth (1859-1916), cujo trabalho Sexualreligion, de 1897, descreve a vida sexual dos arianos, supostamente calcada em uma prática sagrada de eugenia, que tinha como objetivo manter a pureza da raça. Antecipando a ariosofia ao combinar ocultismo e doutrinas raciais com bizarras interpretações da mitologia teutônica, ele insistia na importância da eugenia para a superioridade ariana, convicção essa calcada em suas especulações ocultistas de princípios opostos (matéria e espírito), e na crença de que apenas "opostos puros" poderiam liberar essa "energia primária" oculta na polaridade e assim a força messiânica para criar uma descendência perfeita. Reconhecendo no artigo Die Gnosis (A Gnose, de 1903) sua dívida para com Sebaldt, que acreditava na criação do cosmos a partir de um ardente caos primitivo pelo deus Mundelföri, List assegurava que a suástica seria um símbolo sagrado ariano derivado da Feuerquirl (escova de fogo) com a qual Mundelföri teria feito do cosmos um ser. Com List,

\footnotetext{
"Os deuses teutônicos Wotan, Donar e Loki foram interpretados como símbolos de idéias cosmológicas esotéricas, cuja raiz sebaldtiana podia ser absolutamente evidente para os seus contemporâneos. Este artigo [Die Gnosis] marcou o primeiro passo na articulação de uma religião ocultista germânica feita por List, cuja preocupação principal era a pureza racial",22.
}

Os trabalhos de List da primeira década do século XX, como Rita der ArioGermanen (Ritos dos ario-germanos - 1908) e Die Bilderschrift der Ario-Germanen (A escrita pictórica dos ario-germanos - 1910) já se apresentavam como uma clara síntese entre a teosofia e a mitologia germânica com forte influência de A doutrina secreta de Mme. Blavatsky:

\footnotetext{
${ }^{21}$ Idem, ibidem, p. 78-79.

${ }^{22}$ Idem, ibidem, p. 78.
} 
"Segundo List, os ario-germanos representavam a quinta e atual raça do presente ciclo, e atribuía os nomes dos gigantes míticos teutônicos às quatro raças precedentes. Os atlantes diluvianos foram igualados aos parentes do gigante Bergelmir, que segundo a mitologia norueguesa haviam sobrevivido a uma inundação, enquanto que a terceira raça se relacionava com o grupo de parentes do gigante Thrudgelmir. Junto com Blavatsky, List sugeria que a terceira raça (lemurianos) teriam sido os primeiros a propagarem-se através da reprodução sexual. As duas raças anteriores, quer dizer, a progênie de Ymir e Orgelmir, eram andrógenos e correspondiam naturalmente às raças Astral e Hiperbórea de Blavatsky",23.

Quanto à mitologia política criada por List - que apelava para a já mencionada casta sacerdotal - remetia a um antigo mito teutônico a que Tácito faz referência em seu Germânia. Segundo este, o relato das origens dos antigos germanos teriam sobrevivido nas canções populares que falavam das tribos constitutivas da antiga Germânia: Ingaevones, Hermiones e Istaevones. Para List, essas tribos representavam, na verdade, estamentos sociais ario-germânicos, representando, respectivamente, os estamentos da agricultura, intelectual e militar. À fantasia política de List importava o estamento intelectual, supostamente representado por reis-sacerdotes, e a partir da germanização da palavra "Hermiones", convertida a "Armanen" (herdeiros do rei-Sol), a casta sacerdotal a que se referia List passou então a chamar-se Armanenschaft - comunidade armanista. Sendo assim, nas fantasias de List, no passado germânico, vários milênios antes da colonização romana, havia uma sociedade de castas dominada por uma elite portadora de "segredos" místicos que não estavam acessíveis a todos. Como em toda sociedade secreta, havia graus de iniciação que correspondiam a níveis de instrução, exotérica e esotérica:

"A doutrina exotérica (wotanismo) assumia a forma popular de mitos e parábolas dirigidos às classes sociais mais baixas, enquanto que a doutrina esotérica (armanismo) estava relacionada com os mistérios da gnosis e se achava restrita aos aptos a desempenhar as funções mais elevadas" ${ }^{24}$.

As influências mais evidentes remetiam à maçonaria, aos Rosa-cruzes, à alquimia e à cabala. Tais conhecimentos ocultos, de acordo com List, teriam sobrevivido até o presente através das sociedades secretas, guardiãs do mundo armanista

\footnotetext{
${ }^{23}$ Idem, ibidem, p. 80.

${ }^{24}$ Idem, ibidem, p. 84.
} 
contra o efeito destrutivo do cristianismo. E tal tradição deixara marcas que podiam ser decifradas a partir de ruínas e monumentos antigos presentes na porção austríaca do império Habsburgo. List reconstituíra, a partir do contato com essas ruínas e de suas intuições clarividentes, a pré-história germânica, descrevendo em detalhes eventos históricos e heróicos que teriam acontecido muitos séculos antes nesses lugares. List conseguiu a partir dessas interpretações ocultistas "nacionalizar o passado remoto de acordo com a ideologia contemporânea do pangermanismo",25.

\section{O surgimento da ariosofia: a teozoologia de Lanz von Liebenfels, a revista Ostara e a Ordo Novi Templi (ONT)}

Mas na Viena do final do século XIX, List não era o único a cultivar a fantasia aristocrática de um mundo proto-ariano perdido na noite do tempo. Um contemporâneo seu, a que já fizemos referência antes - Jörg Lanz von Liebenfels - também influenciou decisivamente os rumos do nacionalismo pangermânico através de suas visões místicas de caráter racista.

Lanz von Liebenfels, que dizia ter nascido em $1^{\circ}$ de maio de 1872 em Messina, nascera mesmo em Viena-Penzing em 19 de julho de 1874 e era filho do professor Johann Lanz. Descendente de uma família burguesa vienense, essa realidade era bastante diferente daquela que Lanz iria pintar na vida adulta, ligando suas origens á aristocracia, como também fizera o velho guru que ele admirava, Guido von List. Aliás, talvez seguindo mesmo o exemplo de Lanz. Como List, Lanz von Liebenfels também era um apreciador dos estudos de heráldica (ciência que estuda a história e o significado dos brasões), conhecimento este bastante conveniente na hora de se tentar ligar a própria linhagem a antepassados nobres.

Quando jovem, Lanz já demonstrava um profundo interesse romântico por histórias medievais, sobretudo pelas lendas populares acerca da ordem militar dos Cavaleiros templários, interesse que fez com que ele ingressasse, aos vinte e um anos, como noviço em uma abadia cisterciense em Viena. O clima religioso da abadia de Heiligenkreuz exalava uma atmosfera cavalheiresca e romântica que viria influenciar decisivamente sua trajetória místico-política. Sua primeira intuição (de caráter

\footnotetext{
${ }^{25}$ Goodrick-Clarke, N. Las oscuras raices del nazismo, p. 96.
} 
francamente herético) teve lugar quando da descoberta, em uma escavação, de uma lápide que remontava supostamente ao século XIII e representava um nobre esmagando com os pés um animal não identificado. Lanz viu aí uma interpretação alegórica da luta eterna entre o bem e o mal. Convencido de que o mal no mundo (da mesma forma como fez Mme. Blavatsky) poderia ser creditada à natureza animal (subumana), ele decide estudar zoologia. Posteriormente inspirado pelas descobertas arqueológicas e pelas fantasias antropológicas da época, Lanz não tarda a identificar (como fizeram os darwinistas sociais) em um dualismo cósmico, neo-maniqueísta, a raça loira de olhos azuis com o princípio do bem, e os negros, mongóis e "mediterranóides" com o princípio cósmico do mal. Como ressalta Goodrick-Clarke, "a contribuição de Lanz à ideologia racista foi a incorporação de preconceitos e idéias científicas em uma doutrina gnóstica, que caracterizava as raças loiras e negras como entidades cósmicas que trabalham respectivamente para a ordem e o caos do universo",26.

Algum tempo depois, em abril de 1899, Lanz abandona Heiligenkreuz. De acordo com os superiores da abadia, por falta de vocação, mas segundo Lanz, porque a ordem teria abandonado suas doutrinas (racistas, obviamente) originais. Liberado de seus votos religiosos, ele prossegue seus estudos em paleontologia, antropologia e mitologia, tendo sua imaginação se desviado para recentes descobertas arqueológicas acerca dos assírios, mais particularmente para figuras em relevo que mostravam os assírios conduzindo animais como se fossem mascotes. Lanz se deixa levar por especulações muito fantasiosas e chega a concluir que tais animais seriam na verdade pigmeus com os quais as raças arianas teriam cometido bestialismo e dado origem a uma nova linhagem de seres inferiores, tudo isso emoldurado por passagens do Antigo Testamento que lhe serviam de confirmação para suas hipóteses pseudocientíficas. Tinha sido então revelada a fonte de todos os males do mundo e o segredo da Bíblia:

\footnotetext{
"De acordo com a sua teologia, a queda significava simplesmente que a raça ariana havia ficado comprometida graças ao cruzamento com espécies animais inferiores. A conseqüência desses pecados persistentes, logo institucionalizados como cultos satânicos, foi a criação de várias raças misturadas, que ameaçavam a autêntica e sagrada autoridade dos arianos em todo o mundo, especialmente na Alemanha, onde esta raça era mais numerosa"27.
}

\footnotetext{
${ }^{26}$ Idem, ibidem, p. 125.

${ }^{27}$ Idem, ibidem, p. 127.
} 
Seu trabalho de 1905 já deixa explícito no título a essência de seu pensamento místico e de certa forma gnóstico: A teozoologia ou a ciência dos sodom-simiescos e do elétron dos deuses. O texto, digno de competir com a Doutrina Secreta de Blavatsky, não fazia uso dos jargões orientalistas da teosofia, mas seguia claramente a mesma "metodologia" de trabalho, bem como chegava a conclusões bastante semelhantes. Por conta de sua formação católica, os argumentos de Lanz apelavam para a tradição judaico-cristã ao mesmo tempo em que a transformava de acordo com sua gnose contaminada pela teosofia. Sua teosofia era, portanto, uma teozoologia, porque misturava suas crenças judaico-cristãs com as ciências da vida. Já a referência aos "elétrons dos deuses" mostra que ele estava muito atento às novas descobertas na Física, sobretudo no que concernia à descoberta da radioatividade.

Para ele, os deuses representavam formas superiores de vida (theozoa) anteriores e superiores a uma raça de homens-bestas (anthropozoa). Estes seres superiores eram dotados de órgãos sensoriais especiais que lhes conferiam poderes mentais extraordinários, mas que atrofiaram por conta da mestiçagem desses homens-deuses com os homens-bestas. Por isso, "Lanz insistia que um programa universal de segregação poderia chegar a restaurar esses poderes aos arianos, já que eles seriam os descendentes mais próximos dos homens-deuses" 28 .

A partir de 1905, List passaria a divulgar suas idéias a partir de uma revista quinzenal, inicialmente dedicada a uma discussão anti-liberal e pangermânica dos problemas econômicos e políticos relacionados com o império Habsburgo. A lendária revista Ostara (nome da deusa pagã da primavera) se transformaria rapidamente em um dos mais célebres veículos de divulgação de idéias racistas. A revista, que chegou a influenciar os devaneios de Hitler em sua juventude em Viena e a moldar a concepção de mundo nacional-socialista, segundo seu próprio manifesto informativo a seus leitores dizia ser "a primeira e única revista 'econômico-racista' que tinha como objetivo aplicar o resultado de investigações antropológicas para combater cientificamente a revolta dos inferiores e proteger a nobre raça européia"29.

A revista Ostara conseguiu conectar vários elementos que estavam soltos na cultura völkisch, como o nacionalismo, o paganismo e o racismo, alinhavando todas essas tendências em torno do núcleo razoavelmente estruturado do ocultismo, capaz de promover essas tendências de forma muito mais eficiente. As pseudociências, por sua

\footnotetext{
${ }^{28}$ Idem, ibidem, p. 129.

${ }^{29}$ Idem, ibidem, p. 133-134.
} 
vez, como era o caso do darwinismo social, também formavam suas agremiações, como foi o caso da Liga Monista - fundada em 1906 por Haeckel - e forneciam parte da substância para os devaneios dos artigos da revista. A teosofia, como já pudemos notar, comparecia com as fundamentações de base, sempre sob a regência de Blavatsky e, posteriormente, de sua sucessora como líder da Sociedade Teosófica Internacional, Annie Besant.

Como vimos, Lanz nutria um grande interesse pela idade média e seu ingresso na ordem cisterciense indica sua fascinação pela lenda criada em torno dos Cavaleiros templários, que ele pregava serem os representantes medievais de uma gnose racista. De acordo com Lanz, eles teriam a ambição de criar uma Ordem-Estado da Grande Alemanha, englobando todo o Mediterrâneo e estendendo-se até o Oriente Médio. Naqueles tempos na Alemanha, graças à influência de Richard Wagner, a mitologia em torno de Parsifal e do Graal estava em alta. Para Lanz, a perseguição aos cavaleiros templários significava o triunfo das raças inferiores contra os defensores do culto eugênico, tensão que teria conduzido à desordem do mundo moderno. Tomado por essas convicções, Lanz decide refundar a desaparecida ordem religiosa através da sua Ordo Novi Templi (ONT), que tinha como sede, em 1907, o castelo Borg Werfenstein, então uma ruína medieval. Na mais exemplar tradição do ocultismo, de sempre tentar ligar o presente ao mais remoto passado, Lanz associa Wefenstein - pasmem - com os nibelungos do século $\mathrm{V}$.

Na edição de Ostara de dezembro de 1907, Lanz publica o programa da ONT, que descrevia a ordem como "uma associação ariana de assistência recíproca, fundada para fomentar a consciência racial através da investigação genealógica e heráldica, concursos de beleza e a fundação de utopias racistas nas regiões subdesenvolvidas do mundo" 30 . Não seria necessário muito esforço intelectual para perceber as implicações dessas idéias no desenvolvimento, três décadas depois, do projeto eugênico do nacionalsocialismo. Mas, mesmo assim, a história tradicional do nazismo sempre passou ao largo dessas influências. E se ainda restarem dúvidas acerca da importância da teozoologia de Lanz, convém lembrar que o primeiro artigo das regras da Ordem dos Novos Templários a descrevia como "uma sociedade racial e religiosa, a que podiam afiliar-se apenas as pessoas de sangue predominantemente puro, quer dizer, pessoas mais ou menos loiras, de olhos azuis e que possuíssem um aspecto 'ário-heróico",31.

\footnotetext{
${ }^{30}$ Idem, ibidem, p. 144.

${ }^{31}$ Idem, ibidem, p. 145.
} 
Com os distúrbios causados pela guerra, Lanz teve confirmadas suas angústias de que as raças inferiores poderiam triunfar sobre os loiros de olhos azuis e sangue puro. A convicção de que a perda do prestígio das elites tradicionais devia-se a uma conspiração judeu-bolchevique-maçônica que imprimirá em sua gnose racista a estampa do anti-semitismo.

Ao longo dos últimos anos da guerra, Lanz trava contato com o industrial de Viena Johann Waltharia Wölfl, assíduo leitor da revista Ostara e que lhe ofereceu financiamento com a condição de ser nomeado prior de Werfenstein, tendo em conta que Lanz em breve partiria para a Hungria. Sob a direção de Wölfl, a seção austríaca da ONT prosperou, mas o novo prior da Ordem dos Novos Templários pretendia fazer com que as idéias da ONT (predominantemente esotéricas, apesar das divulgações na Ostara do pré-guerra) pudessem alcançar um público mais amplo. Com a autorização de Lanz, ele inicia então uma nova série de publicações da revista em fevereiro de 1927. Não bastasse esse novo impulso exotérico, Wölfl passa a divulgar as idéias da ONT para o público de direita vienense a partir da associação Lumenclub, que atuou como um centro de expansão do partido nazista na Áustria, quando este ainda estava na ilegalidade.

Enquanto isso, Lanz, que mudara para a Hungria por causa da decepção com uma administração socialista na Áustria (coisa que confirmava suas teorias conspiracionistas), passava o seu tempo militando na causa contra-revolucionária em Budapeste, onde o clima parecia ser muito mais favorável às suas idéias políticas que Viena. A atuação da ONT esgotou-se com o fortalecimento dos regimes autoritários que se deu com a aproximação do novo conflito mundial. A ONT, aponta Goodrick-Clarke,

\footnotetext{
"foi um sintoma de sentimentos de descontentamento difusamente expressados e o amálgama de suas [de Lanz] preocupações, interesses e estilos, claramente em sintonia com os desejos das sociedades austríaca e alemã. Suas próprias respostas, elitistas e milenaristas a esses desejos formavam parte de um impulso genocida. O objetivo final da ONT era a salvação do mundo através da seleção eugênica e o extermínio dos que pertenciam às raças inferiores" ${ }^{32}$.
}

\footnotetext{
${ }^{32}$ Idem, ibidem, p. 159. Grifo nosso.
} 


\section{O armanismo e a ariosofia na Alemanha: de Rudolf von Sebottendorff e a Thule} Gesellschaft à Sociedade Edda

As idéias de List alcançaram a Alemanha através de um grupo de discípulos que se encarregou de transmitir o armanismo a organizações racistas como a Germanenorden (Ordem dos Germanos) e a Reichshammerbund, grupos violentamente anti-semitas cujas origens ligam-se a Theodor Fritsch, figura de expressão na história do anti-semitismo alemão anterior à Primeira Guerra Mundial.

Nascido em 1852, no seio de uma família de camponeses em Wiesenau, lá se tornou operário de moinhos para logo em seguida, graças aos seus talentos editoriais, converter-se em ativista em prol dos pequenos proprietários de moendas, editando a partir de 1880 o Kleine Mühlen-Journal, e em 1882 organizando uma liga alemã de pequenos proprietários de moinhos. Sua preocupação era o crescimento das atividades dos grandes proprietários, que ameaçavam a sobrevivência dos pequenos comerciantes. Como os grandes financiadores dos interesses das grandes empresas eram os judeus, as atividades políticas de Fritsch se viram impregnadas de anti-semitismo. Rapidamente as pequenas agremiações e os panfletos racistas criados por Fritsch atingiram um público mais amplo, dando origem a dois partidos anti-semitas: o Deutsch-Soziale Partei (Partido Social Alemão), liderado por Max Liebermann von Sonnenberg, e o Antisemitische Volkspartei (Partido Popular Anti-Semita), dirigido por Otto Böckel.

Porém, graças à sua desconfiança acerca da eficácia desses partidos como força política, Fritsch não se candidata por nenhum deles. Seu sonho era mesmo desenvolver o movimento anti-semita fora do parlamento. Para tanto, em 1902 ele funda a revista Hammer (Martelo), cujos leitores começaram a se agrupar em núcleos locais (os Hammer-Gemeinden). Grande parte de seus membros eram provenientes de outros agrupamentos, como a Jugendbundbewegung (Movimento da Liga da Juventude) e da Associação dos Empregados Comerciais Nacionalistas Alemães (DHV), que em 1908 adotaram o nome de Grupos de Renovação Alemães.

Após a derrota dos conservadores nas eleições de 1912, com o Partido Social Democrata conseguindo 110 lugares no Parlamento, mais que dobrando sua participação anterior, Fritsch incentiva os leitores de Hammer a reagirem imediatamente. A reação se dá com a fundação de dois grupos pangermanistas e antisemitas. Um deles, o Reichshammerbund, ficou sob controle do coronel Karl August Hellwig, membro desde 1908 da Sociedade List. O segundo grupo, a organização 
secreta Germanenorden (Ordem dos Germanos), ficou a cargo de Hermann Pohl, um inspetor de pesos e medidas em Magdeburgo.

Acerca da Germanenorden, Goodrick-Clarke afirma que "a noção de um grupo anti-semita organizado como uma loja secreta quase maçônica parece haver surgido entre as atividades völkisch por volta de $1910^{, 33}$. O argumento desses grupos era o de que apenas uma conspiração anti-semita secreta seria capaz de combater a também secreta conspiração judaica. Criada a Germanenorden, ela expandiu-se rapidamente para diversas cidades alemãs. Em dezembro de 1912 já se contavam lojas em Breslau, Dresden, Königsberg, Hamburgo, Berlim e Hannover. No ano seguinte, surgiram lojas em Duisburg, Nuremberg e Munique. De inspiração francamente ariosófica, a ordem exigia de seus membros detalhes sobre a cor dos olhos, dos cabelos e da pele, vedando o acesso aos deficientes físicos. Para maiores esclarecimentos, os candidatos eram remetidos às publicações da revista Ostara, onde se tratava da somatologia racial. O objetivo principal da Germanenorden era, segundo uma circular da ordem, "o monitoramento dos judeus e de suas atividades por meio da criação de um centro para o qual confluiria todo o material anti-semita para sua distribuição" ${ }^{\text {34 }}$. A cerimônia e o ritual de admissão à ordem lembravam aqueles da maçonaria, porém com conteúdo racista e embalados pela música de Richard Wagner. O ritual da suástica, bem como juramentos frente à "lança de Wotan" e alusões ao Graal faziam parte das cerimônias.

A guerra de 1914 trouxe dificuldades para a Germanenorden. Aos problemas financeiros seguiram-se críticas à administração de Hermann Pohl que, irritado, acabou por fundar em 1916 em novo grupo, uma Germanenorden cismática chamada Walvater do Santo Graal ou Germanenorden Walvater. A confusão fez com que todos pensassem que a Germanenorden tivesse se dissolvido. Neste ponto parece mesmo reinar uma certa confusão acerca do destino da ordem, mas após o final da guerra alguns membros antigos surpreenderam-se em revivê-la. Até 1921, a ordem parece ter atuado como um centro de recrutamento de assassinos políticos, cujos alvos incluíam inimigos judeus. Depois de 1921, ela teria se convertido em apenas mais um dos inúmeros grupos antisemitas da Alemanha.

Mas o futuro da Ordem dos Germanos mudaria quando, ainda em 1916, os caminhos da cismática Germanenorden Walvater e de um certo Rudolf von Sebottendorff se encontraram. Com ele, tanto a ariosofia quanto a Germanenorden

\footnotetext{
${ }^{33}$ Goodrick-Clarke, N. Las oscuras raices del nazismo, p. 167.

${ }^{34}$ Idem, ibidem, p. 169.
} 
foram salvas dos porões da história, passando a integrar definitivamente um capítulo na biografia nacional-socialista.

Nascido em 1875 em Hoyerswerda, Adam Alfred Rudolf Glauer era filho de um operário ferroviário e ex-combatente nos conflitos austro-prussianos e francoprussianos. Apesar dos estudos em engenharia, Glauer abandona a vida de estudante e decide aventurar-se como marujo, após trabalhar como estivador por alguns meses. Em abril de 1898 ele parte em um navio rumo a Nova York. Em seguida, como eletricista em um outro navio, ele parte para a Austrália, e depois de mais algumas aventuras fracassadas tentando a sorte com a exploração de minas de ouro, chega ao Egito. Chegando a Alexandria em julho de 1900, viaja logo em seguida para o Cairo, onde consegue um emprego técnico. Aqui há informações contraditórias sobre o tempo de permanência no Egito, mas parece que o período de trabalho não durou muito e ele ruma para Constantinopla. Encantado com a cultura, decide aprender turco e aceita trabalhar como agrimensor nas terras de um proprietário local.

E foi enquanto trabalhava na Turquia, inspirado pelas religiões exóticas (como a seita Mevlevi) que ele começou a estudar ocultismo. Ali ficou conhecendo o significado cosmológico e numerológico das pirâmides (que ele conhecia), bem como travou contato com uma família de judeus gregos franco-maçons que estudavam cabala e colecionavam textos de alquimia e rosacrucianos. O patriarca da família iniciou Glauer na maçonaria e, ao morrer, deixou para este sua biblioteca de ocultismo. Segundo relatos, ele teria retornado à Alemanha e fixado residência em Munique em 1902. De qualquer forma, no final de 1908 Glauer é localizado em Constantinopla, onde continua estudando o misticismo islâmico que, de acordo com sua opinião, compartilharia uma fonte ariana comum com as runas germânicas. Segundo Goodrick-Clarke,

\footnotetext{
“A visão política de Glauer estava basicamente inspirada por sua orientação religiosa: o anti-materialismo e o misticismo panotomano, a alquimia e o rosacrucianismo, combinado com um ódio do pós-guerra contra o bolchevismo, que ele identificava como o ápice do materialismo levaram-no a identificar-se com ideais anti-democráticos”35.
}

Alguns anos depois, Glauer sucumbiu à tentação aristocrática a que tanto Lanz quanto List, como vimos, não conseguiram resistir: a de reivindicar para si ancestrais nobres adotando o nome e o título de "von Sebottendorff von der Rose". Mas as

\footnotetext{
${ }^{35}$ Idem, ibidem, p. 182.
} 
justificativas para a utilização do título de nobreza superam a imaginação de seus predecessores.

De acordo com uma das versões, Glauer teria se naturalizado turco em 1911 e em seguida teria sido adotado pelo barão expatriado Heinrich von Sebottendorff, transformando-se assim em Rudolf von Sebottendorff, mas como tal procedimento não era reconhecido na Alemanha ele repetiu sua adoção por Sigmund von Sebottendorff von der Rose (1843-1915) em Wiesbaden, em 1914. A família Sebottendorff remontava ao século X e até o século XVIII existiriam pelo menos duas linhagens: a linhagem von der Rose e a Lortzendorff ${ }^{36}$.

Agora um "nobre" (considerando a primeira "adoção" em 1911), Rudolf von Sebottendorff (ex-Glauer), depois de lutar ao lado das forças turcas na segunda guerra balcânica em 1912 (onde foi ferido sem gravidade) retorna a Berlim em 1913, para depois ressurgir casado pela segunda vez em 1915 (o primeiro casamento teria sido em 1905 em Dresden, durando apenas dois anos). Difamado como um caça-fortunas por conta desse seu casamento com uma rica herdeira e também enfrentando problemas por conta de sua nacionalidade turca, ele e a esposa mudam-se diversas vezes até se estabelecerem na Bavária. Daí ele consulta seu advogado em Munique sobre os problemas com a nacionalidade turca, e casualmente o advogado lhe mostra um jornal da Germanenorden convocando os alemães puros (loiros de olhos azuis) para unirem-se à ordem. Curioso, Sebottendorff candidata-se como membro e ao visitar o chefe da ordem em Berlim ele conhece Hermann Pohl.

O contato de Sebottendorff com Pohl parece ter ocorrido pouco antes da cisão no interior da Ordem dos Germanos e da posterior criação da facção cismática da Germanenorden-Walvater. A partir daí, Sebottendorff começa a atuar no interior da ordem recrutando novos membros, com o auxílio de um estudante de arte, Walter Nauhaus, que tinha interesse em ocultismo, cabala e na religiosidade hindu e egípcia. $\mathrm{O}$ número de membros crescia e eram freqüentes as reuniões para a investidura dos noviços, com a realização de conferências esotéricas e excursões. Com o tempo, essas atividades passarão a incluir comícios políticos de extrema-direita, e para que a ordem não afastasse os socialistas e os republicanos adotou-se, na intenção de encobrir o nome da ordem, a denominação de Thulegesellschaft (Sociedade Thule). O emblema da

\footnotetext{
${ }^{36}$ Idem, ibidem, p. 183.
} 
sociedade era representado por uma adaga com um sol brilhante ao fundo e inscrito nele o símbolo da cruz gamada (suástica).

Logo após a criação da Sociedade Thule, levantes revolucionários assolaram a Alemanha nas primeiras semanas do pós-guerra. Com dois dias de antecedência em relação a Berlim, um grupo de revolucionários de esquerda derrubou a milenar dinastia dos Wittelsbachs em Munique. Kurt Eisner, então líder dos social-democratas independentes, estava à frente do movimento. Convertido em ministro-presidente, Eisner (que de certa forma era um pacifista) ousou falar da responsabilidade da Alemanha na guerra para um auditório de socialistas, o que fez com que ele perdesse o resto do quase nenhum apoio de que dispunha. A derrota eleitoral que se seguiu tornou insustentável a sua posição, obrigando-o a demitir-se do cargo. O impacto desses acontecimentos sobre a direita alemã, mais especificamente sobre os grupos völkisch, foi imediato.

As coisas não andavam nada bem para os militantes de direita: a Alemanha perdera a guerra, o Kaiser e os príncipes estavam abdicando e os judeus proclamavam repúblicas socialistas. Em resposta a esse desastre, na noite de sábado, 9 de novembro de 1918, na sede da Sociedade Thule, Sebottendorff fez um discurso inflamado, mesclando sentimentos anti-semitas, monárquicos e ariosóficos:

“Ontem experimentamos o colapso de tudo o que era familiar, querido e valioso para nós. Em lugar de novos príncipes de sangue alemão, governa nosso inimigo mortal: o judeu. O que resultará desse caos, ainda não sabemos. Haverá um tempo de luta, da mais amarga necessidade, um tempo de perigo... Enquanto eu sustentar o martelo de ferro [referência ao martelo ritual da ordem], estarei determinado a comprometer os Thule em luta. Nossa ordem é uma ordem germânica, a lealdade é também germânica. Nosso Deus é Walvater, sua runa é a Av-runa. E a trindade: Wotan, Wili, We, é a unidade da trindade. A Av-runa significa o ariano, o fogo original, o sol e a águia. E a águia é o símbolo dos arianos. A fim de representar a capacidade da águia para o auto-sacrifício por meio do fogo, ela está pintada em vermelho. De hoje em diante nosso símbolo será a águia vermelha, que nos adverte que devemos morrer para poder viver" 37 .

Como já dissemos antes, o nome Thule nos remete à tradição helênica, onde Thule seria o reino da misteriosa terra dos hiperbóreos, berço da raça original e fonte de

\footnotetext{
${ }^{37}$ Citado por Goodrick-Clarke, Las oscuras raices del nazismo, p. 188.
} 
grande poder. Já a menção da Av-runa como representante do sol, bem como a ressurreição da águia como um símbolo germânico específico do renascimento, Goodrick-Clarke nos informa que essas relações haviam sido traçadas por List. O mesmo em relação à trindade Wotan, Wilie e We, como parte da cosmogonia teosófica germânica.

O historiador Joachim Fest, autor de uma obra magistral e até hoje o principal referencial quanto à biografia de Hitler, mesmo sendo um representante da historiografia tradicional sobre o nazismo (ele cita Adorno, Marcuse, Hannah Arendt, Lukács e Franz Neumann, dentre outros), não deixa de notar a importância da associação Thule e das sociedades secretas sobre o desenvolvimento do nacionalsocialismo. Ao discutir a associação de Sebottendorff, ele nos informa que desde outubro de 1918 alguns membros da Thule teriam elaborado planos visando um golpe de Estado de direita, que passavam pelo assassinato de Kurt Eisner ${ }^{38}$.

De qualquer forma, apesar das evidências de que o governo revolucionário não conseguiria se sustentar por muito tempo, Eisner foi assassinado em 21 de fevereiro (no momento em que rumava para o Landstag com a intenção de entregar sua demissão) por um jovem de 22 anos, o conde Anton von Arcovalley. Segundo as informações de Goodrick-Clarke, Valley seria "um jovem judeu ressentido por sua exclusão de Thule, que queria provar seu compromisso nacionalista"39. O ingênuo Anton não só perdeu tempo com esse atentado, como deixou de notar que a Thule, nascida da Germanenorden, não estava apenas em busca de jovens nacionalistas, mas de alemães "puros". No futuro, muitos outros alemães, incluindo veteranos de guerra (cujo sangue seria de procedência duvidosa) haveriam de cometer o mesmo erro. Os números da revista Ostara, publicados entre 1908 e 1913, sobre pureza racial, eram um presságio...

A partir do assassinato de Eisner, a onda de violência prosseguiu movida por um efeito dominó. Algumas horas após o assassinato, o açougueiro e garçom membro da extrema-esquerda, Alois Lindner, invadiu o salão do Landstag e abateu a tiros o ministro Auer, matando também outras duas pessoas. Decretado estado de exceção na Baviera, houve uma greve geral logo em seguida e o fechamento da Universidade, onde alguns alunos consideravam Arco-Valley um herói. Quando a situação começou a esfriar, notícias da Hungria, onde Bela Khun havia proclamado a ditadura do proletariado, voltaram a agitar a região da Baviera. O grupo de revolucionários começou

\footnotetext{
${ }^{38}$ Fest, J. Hitler, p. 136.

${ }^{39}$ Goodrick-Clarke, Las oscuras raices del nazismo, p. 191.
} 
o confisco de bens e o arbítrio fazia e executava reféns membros da burguesia e da aristocracia. Nesse contexto deu-se o incidente que demoraria anos para abandonar a lembrança da opinião pública. Oito membros da Sociedade Thule, muitos deles nobres, foram feitos reféns e depois assassinados em represália por conspiração de extremadireita $^{40}$. Sobre o incidente, Goodrick-Clarke nota que por conta de sua propaganda contra-revolucionária e do martírio dos reféns, a Germanenorden e a Sociedade Thule ajudaram a criar um clima de rancor onde o nacional-socialismo pôde prosperar ${ }^{41}$.

E essa constatação não é gratuita. No seio da sociedade Thule, Sebottendorff criou um espaço de agregação para membros de pangermanistas e os documentos da época mencionam os nomes de Dietrich Eckart (futuro editor do Völkisch Beobachter), Gottfried Feder (principal filósofo econômico do futuro partido nazista), Hans Frank (futuro advogado pessoal de Hitler), Rudolf Hess (que chegaria a ser vice-líder do partido nazista, logo abaixo de Hitler), Karl Harrer (um dos fundadores do DAP) e Alfred Rosenberg (principal ideólogo do partido nazista).

Mas a Thule apenas não era suficiente. Em 1918 Sebottendorff decidiu que os ideais racistas herdados de List e Lanz von Liebenfels, bem como os ideais nacionalistas pangermânicos, deveriam descer até as classes trabalhadoras, e para isso pede que Karl Harrer (1890-1926), então um jornalista de esportes, criasse um círculo de trabalhadores. Com Harrer como presidente e o operário Anton Drexler formou-se um pequeno grupo que se reunia semanalmente para discutir temas como as causas da derrota alemã, o inimigo judeu e a hostilidade contra os ingleses. Em dezembro deste mesmo ano, seguindo a sugestão de Drexler, o pequeno grupo decidiu fundar um partido. Surgiu assim, no dia 5 de janeiro de 1919, no salão de uma cervejaria, o Deutsche Arbeit Partei (DAP - Partido Trabalhista Alemão), cujos membros eram todos amigos de Drexler da indústria ferroviária.

Os negócios da Thule prosperavam e além do DAP a sociedade possuía também seu próprio veículo de divulgação em larga escala. Nos subúrbios de Munique circulava desde 1868 um jornal local com certa inclinação anti-clerical e anti-semita que de 1900 em diante esteve sob a administração de Franz Eher. Quando Eher morreu, em junho de 1918, o jornal deixou de circular durante alguns meses, até que Sebottendorff o

\footnotetext{
${ }^{40}$ Fest, Joachim, Hitler, p. 129-130. Convém notar também que a execução dos membros da Thule foi notícia no The Times de 5 de maio de 1919, chocando a opinião pública.

${ }^{41}$ Goodrick-Clarke, Las oscuras raices del nazismo, p. 192.
} 
comprou por 5000 marcos, agregando-o á Sociedade Thule, que agora contava com seu próprio jornal, o Münchener Beobachter, e seu próprio partido político.

E foi exatamente esse crescimento que fez com que os militares se interessassem pelas atividades da Thulegesellschaft e do DAP. Assim, em setembro de 1919, o capitão Mayr encarregou um de seus homens de confiança para fazer uma visita ao DAP. A espionagem desses pequenos grupos extremistas surgidos após a Primeira Guerra costumava ser freqüente. Na reunião de 12 de setembro, Gottfried Feder discursava na cervejaria Sternecker defendendo sua tese acerca de como e por que meios se eliminaria o capitalismo. Após o discurso, teve início um debate em que um dos ouvintes sugeriu que a Baviera deveria se separar do resto do Reich, sendo anexada à Áustria. O espião enviado por Mayr, após escutar tamanha asneira, não resistiu à tentação e atacou os argumentos do aparteante com tanto vigor que deixou Drexler impressionado. Na saída, ele presenteou o intruso com uma brochura de sua autoria Meu despertar político - na qual descrevia, dentre outras coisas, suas dificuldades como operário e sua crença acerca do papel nefasto dos judeus. Dias depois Drexler enviaria, sem que lhe fosse solicitado, um título de membro ao homem que tanto lhe impressionara, convidando-o para uma nova reunião no bar Alten Rosenbad. O homem em questão, encarregado de espionar o DAP e a Sociedade Thule e que despertara a simpatia de Drexler era um certo Adolf. De sobrenome Hitler.

Sobre esse evento histórico na cervejaria Sternecker, que jamais seria esquecido, Hitler recordará muito tempo depois o inusitado contato com o Partido dos Trabalhadores Alemães:

“Na manhã seguinte àquela reunião eu estava deitado, mas acordado, lá pelas 5 horas, assistindo ao movimento dos camundongos. Como não pudesse conciliar o sono, lembrei-me, de repente, da noite passada, e veio-me à lembrança a brochura que o operário me havia dado. Comecei a lê-la. Era uma pequena brochura, na qual o autor, o tal operário, descrevia a maneira pela qual ele tinha chegado de novo ao pensamento nacionalista através da confusão marxista e das frases ocas das corporações profissionais. Daí o título - 'meu despertar político'. Desde o início o livreto me despertou interesse, pois nele se refletia um fenômeno que há doze anos eu tinha sentido. Involuntariamente vi se avivarem as linhas gerais da minha própria evolução mental. Durante o dia pensei sobre o assunto várias vezes e ia pô-lo fundamentalmente de lado quando, menos de uma semana depois recebi, com surpresa minha, um cartão postal anunciando que eu tinha sido aceito sócio do 'Partido Trabalhista Alemão'. Pedia-se que eu me externasse a respeito e para isso viesse na próxima quarta-feira a 
uma sessão da comissão do partido. Na realidade eu me sentia mais do que surpreso por essa maneira de ‘angariar' sócios e não sabia se me devia zangar ou rir. Eu não pensava em entrar para um partido já organizado e sim em fundar o meu próprio partido. Essa pretensão de filiar-me a um partido não me tinha passado pela cabeça"42.

Paralelamente a essas tentativas de reação dos grupos extremistas através da criação de partidos políticos que (como o próprio Hitler notará no futuro) apareciam para logo então desaparecerem sem deixar o menor vestígio, vários visionários do movimento Völkisch prosseguiam suas atividades em apoio das idéias ocultistas nacionalistas de Guido von List. Ellegard Ellerbek, por exemplo, admirador de List desde antes da guerra, estava empenhado em uma campanha anti-republicana utilizando para difamar os aliados conceitos extraídos da teosofia, do gnosticismo, tudo isso com pinceladas de anti-semitismo. Em suas conferências na Alemanha, Ellerbek tentava convencer seu auditório de que o sangue alemão descendia dos antigos deuses pagãos. A própria sociedade List, por sua vez, continuava ativa, com sua sede em Berlim.

Porém, o movimento começava a se renovar, a partir de novas tendências ocultistas, calcadas nas runas e nas $E d d a$. Um nome importante dessa tendência foi Rudolf John Gorsleben, idealizador de uma religião racista original que, sob a égide da herança mágica dos arianos, tentava justificar a supremacia alemã tanto no plano espiritual quanto na política. Nascido em Metz, no dia 16 de março de 1883, Gorsleben havia crescido na Alsácia-Lorena. Essa região, objeto de disputas seculares, havia sido anexada pelo Cardeal Richelieu - o todo-poderoso dirigente da França - durante a Guerra dos Trinta Anos (que terminou em 1648), e se tornaria daí em diante foco de rivalidade entre franceses e alemães até a Segunda Guerra Mundial. Por conta disso Gorsleben esteve desde muito jovem em contato com o nacionalismo dessa região.

Com o fim da Primeira Guerra, em que se alistara como voluntário em um regimento bávaro, ele regressa a Munique e se junta à Sociedade Thule. No levante revolucionário de 1919, ele foi preso junto com Dietrich Eckart e por muito pouco os dois não foram executados com os outros reféns da Thule. Após um período de militância política, Gorsleben se retira da política völkisch para dedicar-se a seus interesses literários e ideológicos, tempo em que traduziu a Edda, que ele considerava a fonte da religião ariana ${ }^{43}$.

\footnotetext{
${ }^{42}$ Hitler, A. Minha Luta, p. 165.

${ }^{43}$ Goodrick-Clarke, Las oscuras raices del nazismo, p. 199-200.
} 
Através do semanário Die Republik, que ele comprara em 1920, mudando o nome para Deutsche Freiheit (Liberdade Alemã), Gorsleben edita esse jornal de espírito völkisch com o auxílio de colaboradores como Friedrich Wichtl (teórico austríaco da conspiração maçônica mundial) e Hans F. K. Gunther (um antropólogo racista). O jornal, que entre 1920 e 1925 adotava uma linha nacionalista convencional, do final de 1926 em diante prevaleceu o racismo místico com Gorsleben expondo sua própria versão do ocultismo ariano que remetia à astrologia, cabala e à magia. Impregnado de darwinismo social e de arianismo, sua doutrina afirmava que os arianos eram os filhos dos deuses e que o mundo moderno, corrupto e vulgar, seria o resultado da mistura racial. Gorsleben também reafirmava a concepção völkisch que a mulher poderia ser "impregnada", mesmo que não ocorresse a concepção, pelo primeiro coito e que sua descendência carregaria as características de seu primeiro amante. Por isso apenas a segregação e a eugenia poderiam reverter a contaminação racial do mundo. Mas a ênfase de Gorsleben recaía mesmo era sobre a importância da educação ocultista dos arianos e na importância atribuída às runas. Para ele, elas seriam uma representação de deus no mundo e um laço entre o macrocosmo e o microcosmo. Por isso ele tentava mostrar a presença da runa mais sagrada (a runa Haggal) em símbolos e lugares sagrados, como o hexagrama e a pirâmide de Keops. Através de construções geométricas, numerológicas e etimológicas, Gorsleben tentava provar que os cristais seriam projeções geométricas das runas (desenvolvendo toda uma teoria ocultista sobre eles) e, de maneira ainda mais fantasiosa, deduziu que a palavra Kristall (cristal) derivava de Krist-All, "indicando desse modo uma antiga religião de Krist, de proveniência atlântida e ariana que supostamente havia sido expurgada do novo evangelho de Jesus" ${ }^{\prime 4}$.

Gorsleben também via na literatura islandesa, sobretudo nas Edda, a fonte mais importante da história intelectual ariana, convicção que o levou a criar, em 29 de novembro de 1925, um grupo de estudos arianos chamado de Sociedade Edda. Com forte influência de List, a sociedade continuou operando mesmo após a morte de seu fundador, em 1930, passando às mãos de Werner von Bülow (1870-1947), que fez com que a Sociedade Edda prosseguisse de acordo com seus princípios originais de investigar as Edda, bem como outros vestígios dos antigos arianos (os interesses de Bülow dirigiam-se, principalmente, para os mitos em torno de Odin, Brunilda, Gudrun

\footnotetext{
${ }^{44}$ Idem, ibidem, p. 201-202.
} 
e Heimdall). Em 1933 a Sociedade Edda declarou de forma explícita sua adesão ao nacional-socialismo, afirmando logo em seguida que a revolução nazista seguia a determinação de leis cósmicas superiores ${ }^{45}$.

Enquanto isso, Hitler, que após muita hesitação decidira tomar parte no DAP, recebeu o título $\mathrm{n}^{\mathrm{o}} 7$, sendo encarregado da propaganda e do recrutamento de novos membros. As reuniões desde o final do ano (1919), e por insistência de Hitler, vinham acontecendo no subsolo da cervejaria Sternecker. O partido contava então com apenas um punhado de membros, mas a propaganda através do Münchener Beobachter era promissora. Como diz o próprio Hitler, "durante todo o inverno de 1919-1920, nossa principal luta foi no sentido de fortalecer a fé na força conquistadora do novo movimento e elevá-las às alturas do fanatismo capaz de abalar as montanhas"46. No início de 1920 ele insiste para que o partido realize seu grande comício, mas Harrer não concorda com a idéia e retira-se da liderança do movimento, sendo sucedido por Anton Drexler. A vontade de Hitler acaba se impondo e a data é fixada em 24 de fevereiro de 1920, no salão de festas da Hofbräuhaus de Munique. Em meio a algumas agitações (metade do auditório era formada por comunistas e independentes), que foram rapidamente abafadas "por alguns fiéis camaradas da Guerra". Esses "camaradas", decerto companheiros de caserna, representarão em um futuro próximo as bases da milícia paramilitar do partido nacional-socialista. Restabelecida a ordem após alguns socos e pontapés, Hitler pôde prosseguir com seu intento de apresentar o programa do partido, ponto a ponto, explicando depois as 25 teses do movimento. Fest relata que “depois desse acontecimento, a lenda criada pelo partido comparou a manifestação de 24 de fevereiro de $1920 \mathrm{com}$ as teses de Martinho Lutero afixadas nas portas da igreja de Wittenberg" "47. Nessas teses estavam expostas as bases para o enlouquecimento futuro de uma nação inteira: a tese do espaço vital, o anti-semitismo, o anti-capitalismo, a defesa do totalitarismo e o anti-marxismo.

Uma semana depois da exposição das 25 teses, o DAP alterou o seu nome para Nationalsozialistische Deutsch Arbeitpartei (NSDAP) - Partido Nacional-Socialista dos Trabalhadores Alemães, adotando como emblema a cruz gamada. Sobre isso, a escolha dos símbolos do partido, o relato de Hitler é bastante instrutivo:

\footnotetext{
${ }^{45}$ Idem, ibidem, p. 204-205.

${ }^{46}$ Hitler, A. Minha luta, p. 262.

${ }^{47}$ Fest, J. Hitler, p. 148.
} 
“Já na minha juventude, tinha sido, muitas vezes, a ocasião de sentir e compreender a significação psicológica dos símbolos dessa ordem. Depois da Guerra, presenciei uma grande manifestação dos marxistas diante do Palácio Real, no Lustgarten. Uma imensidade de bandeiras, de faixas e de flores vermelhas davam a essa manifestação, na qual tomavam parte, aproximadamente, cento e vinte mil pessoas, uma aparência formidável. Pude sentir com que facilidade o homem do povo é empolgado pela magia sugestiva de um tal espetáculo" ${ }^{\text {48 }}$.

Era necessário, portanto, pensar em uma bandeira que simbolizasse o partido e ao mesmo tempo produzisse um efeito majestoso sobre as massas. As sugestões, em sua maioria, haviam introduzido a cruz suástica, inclusive um dentista de Starnberg, que introduzira a suástica no interior de um círculo branco. De acordo com Hitler, ele mesmo já pensara em algo semelhante, mas havia evitado pronunciar-se prematuramente, com receio de que alguém pudesse ter uma idéia melhor que a dele. Porém, o desenho do dentista apresentava a cruz suástica com os braços curvos, sugestão que foi rejeitada. Depois de inúmeras tentativas, Hitler afirma ter finalmente encontrado a forma definitiva: uma bandeira de fundo vermelho com a cruz suástica de braços retos, em preto, no interior de um círculo branco. A idéia, claramente roubada do dentista Friedrich Krohn, foi apropriada por Hitler, que reconheceu nela todo aquele poder de mobilizar as massas que ele estava buscando: algo com um bom efeito estético e que fosse empolgante. E justificou assim a escolha final:

"Como nacional-socialistas, costumamos ver na nossa bandeira o nosso programa. No vermelho, vemos a idéia socialista do movimento, no branco, a idéia nacional, na cruz suástica a missão da luta pela vitória do homem ariano, simultaneamente com a vitória da nossa missão renovadora que foi e será eternamente anti-semítica"49.

Mas a história da escolha da suástica é um pouco mais complicada do que se pode imaginar. Giorgio Galli, historiador italiano, recorrendo a um livro de Rudolf von Sebottendorff sobre a história da Thule, informa-nos que o dentista Friedrich Krohn era membro tanto da Thule quanto da Germanenorden ${ }^{50}$. Essa informação nos conduz, novamente, às influências armanistas e ariosóficas.

\footnotetext{
${ }^{48}$ Hitler, A. Minha luta, p. 367-368.

${ }^{49}$ Idem, ibidem, p. 371.

${ }^{50}$ Galli, G. Hitler e o nazismo mágico: as componentes esotéricas do III Reich, p. 111.
} 
Com a ajuda de pessoas influentes que apostavam no futuro do partido e do movimento, o NSDAP conseguiu comprar, em dezembro de 1920, o jornal racista Völkisch Beobachter, que estava à beira da falência. O dinheiro, 60.000 marcos, havia sido levantado por Rohn e Dietrich Eckart, que conhecera Hitler em março de 1920. Influenciado por Lanz von Liebenfels, ele pregava nos artigos de sua antiga editora a proibição de casamentos mistos e medidas para garantir a pureza da raça. Dietrich Eckart exerceu grande influência sobre Hitler, "emprestou e recomendou a Hitler alguns livros, deu um certo verniz a suas maneiras, corrigiu suas expressões defeituosas e lhe abriu numerosas portas"

Contando com o talento de Hitler para a oratória e sua vocação para o fanatismo em uma época de instabilidade social, o NSDAP tinha tudo para prosperar. O exército, desde 1920, vinha crescendo em importância e se constituindo como um novo poder no interior do Estado, e junto com ele cresciam também as milícias paramilitares. Estas últimas, somadas à guarda civil, já ultrapassavam o contingente de 300 mil homens, o que preocupava os aliados, já que o Tratado de Versalhes demandava a redução drástica do exército alemão para apenas 100 mil homens. Os aliados exigiram a supressão das milícias e a dissolução de duas brigadas especialmente nacionalistas, as brigadas Erhardt que, a propósito, em 1920 já utilizavam como emblema a cruz gamada. Essa diretriz do Tratado de Versalhes chocava-se com a resistência do governo golpista de Gustav von Kahr na Baviera, que se apoiava exatamente nessas milícias patrocinadas pelas grandes indústrias. Esses grupos paramilitares eram intensamente nacionalistas, tinham como inimigos os socialistas (logo em seguida, foi-lhes acrescentado o ódio aos judeus) e funcionavam na sombra do exército, que via neles uma forma de driblar as exigências dos aliados. E como o governo na república de Weimar esteve por um bom tempo nas mãos da "esquerda" social-democrata, essas milícias (e o próprio exército) estavam sempre prontas para agir como forças contra-revolucionárias.

Foi exatamente aproveitando esse clima tenso da república de Weimar que o NSDAP cresceu, sob a proteção dos comandos militares da região e do chefe de polícia bávaro Pöhner. Hitler, que na companhia do então estudante Rudolf Hess, já havia sido recebido com simpatia por Kahr e elogiado pelo ministro-presidente quando este se dirigia à Landstag (Assembléia Estadual ou Dieta) da Bavária, agora contava com total apoio da polícia. O NSDAP passará então a ser considerado "fator de ordem",

\footnotetext{
${ }^{51}$ Fest, J. Hitler, p. 162-163.
} 
atrapalhando as reuniões dos marxistas, intimidando seus oponentes, enfim, espalhando o terror na Baviera, sobretudo em Munique. Entretanto, para esse fim, Hitler precisou criar sua própria milícia: a temida Sturmabteilung - Tropa de Assalto (SA) - com o intermédio de Röhn, um afiliado do NSDAP e oficial do exército, que por isso mesmo dispunha da influência, do conhecimento e dos meios materiais necessários para se criar um exército político. E foi exatamente Röhn que apresentou Hitler ao general Ludendorff, um dos personagens mais importantes daquela época e que lhe abriria ainda mais as portas da ascensão política. Criada em agosto de 1921, as SA tinham como objetivo principal proteger os líderes nazistas, mas funcionavam também como um instrumento de conquista do poder, e que apesar da importância de Röhn em sua criação, eram comandadas por Hermann Göring, um fantástico piloto de aviões (último comandante do esquadrão von Richthofen ${ }^{52}$ ), em quem Hitler confiava plenamente. A população como um todo, incluindo a burguesia (legalista e avessa à violência) estava hipnotizada pelas demonstrações de força das Tropas de Assalto, com suas braçadeiras, cassetetes e uniformes cinzentos marchando por Munique e "estabelecendo a ordem". Sobre isso, Fest nota que

\footnotetext{
"é bastante revelador o fato de que precisamente nessa época, a palavra nazi se tenha tornado de uso corrente. Realmente, não era mais do que a abreviação de nacionalsocialista, mas possuía um som familiar aos ouvidos bávaros, porque era habitualmente empregada como um diminutivo carinhoso do prenome Inácio. Era a melhor prova de que o partido havia penetrado em grandes camadas da consciência popular,"53.
}

Em 1923 o partido já contava com 50.000 membros e as SA somavam 10.000 homens, contingente suficiente para que Hitler pudesse pensar em um assalto ao poder. Mas para isso ele precisava contar com o apoio do exército, coisa que ele já vinha costurando há algum tempo a partir de seus contatos com von Lossow, superior de Röhn. Então, no dia 8 de novembro, Hitler interrompe uma reunião pública donde Kahr discursava (com eles estavam Alfred Rosenberg e o operário Anton Drexler, que não sabia o que iria acontecer) e manda cercar o local. Tinha início o famoso "Putsch" de Munique. Escoltado pela SA, Hitler anuncia a todos que o governo bávaro e o governo do Reich estavam depostos. Em seguida chamou Kahr e Lossow, que estavam surpresos

\footnotetext{
${ }^{52}$ Sobrenome que no Brasil estará para sempre vinculado a um famoso caso policial. O vínculo não é mera coincidência.

${ }^{53}$ Fest, J. Hitler, p. 176.
} 
e descontentes com essa comédia de bandoleiros, para informá-los da situação, enquanto alguém se encarregava de buscar Ludendorff, que não sabia o que estava acontecendo. Sem qualquer apoio, essa tentativa desastrada de tomar o poder acabou no dia seguinte, quando o partido desfilava pelas ruas tentando demonstrar que o golpe estava consolidado. A marcha terminou em tiroteio, onde dezenas de nazistas foram mortos e Hitler fugiu ferido. Algumas semanas depois ele será preso e julgado por conspiração, enquanto que o herói de guerra Ludendorff, que marchava com ele sem muita convicção, será absolvido.

Dois meses antes, em meio aos preparativos para o Putsch, Hitler, de forma simbólica, havia preparado uma "jornada alemã" em Bayreuth, pedindo para ser recebido na casa de Richard Wagner. Ele "entrou na casa com emoção profunda, visitou o escritório de trabalho do mestre, onde se encontrava sua grande biblioteca, após haver meditado por longo tempo diante de seu túmulo, no jardim". Nessa ocasião, Hitler foi apresentado a Houston Stewart Chamberlain, marido de uma das filhas de Wagner, e cujas obras racistas o haviam influenciado. Chamberlain viu em Hitler o homem capaz de salvar a Alemanha, e suas palavras de apoio, nesse momento, "eram palavras recebidas no momento preciso em que ia tomar uma das grandes decisões de sua vida, pareceram ser um apelo lançado de além-túmulo pelo próprio mestre de Bayreuth em pessoa" ${ }^{54}$. Mas ainda não seria dessa vez.

O julgamento de Hitler por conspiração contra a segurança do Estado mostrou-se um carnaval político. Enquanto todos juravam não saber de nada, Hitler foi o único a reconhecer a veracidade dos fatos, mas recusou-se a se considerar culpado, pois ele lutara pelo bem de seu povo. A audiência, a opinião pública e mesmo a acusação pareciam ser simpáticos à causa de Hitler. Com muito esforço ele foi condenado a cinco anos de prisão, mas ficou preso apenas pouco mais de um ano. No cárcere, Hitler ocupava seu tempo passeando no jardim da prisão, pregando para os companheiros e lendo a volumosa correspondência que recebia regularmente, dentre elas uma homenagem de um estudante de filologia recém diplomado, Joseph Goebbels, que em breve se tornaria seu ministro da propaganda. Foi também aí, no começo de julho, que ele começou a trabalhar no manuscrito do Mein Kampf (Minha Luta), ditando-o até altas horas da noite ao amigo Rudolf Hess, que batia o texto a máquina. Sobre o texto sem

\footnotetext{
${ }^{54}$ Idem, ibidem, p. 220.
} 
naturalidade e cheio de erros de estilo que traem a falsa erudição de seu autor, Fest comenta:

\begin{abstract}
"A firmeza e a obstinação aí se opõem estranhamente à tendência insaciável para a frase torrencial, o desejo sempre evidente de desenvolver um estilo pessoal onde falta a autodisciplina, a lógica onde sobra a obscuridade. Só o egocentrismo monótono e quase maníaco, que aliás corresponde muito bem à ausência de humanidade desse alentado volume, não tem sua antinomia. Por mais fatigante e difícil que seja, no todo, sua leitura, ela fornece, entretanto, um fiel retrato do autor, cuja preocupação constante de não se revelar trai, por isso mesmo, sua verdadeira personalidade" ${ }^{\text {} 55}$.
\end{abstract}

Após a temporada em Landsberg, quando Hitler foi posto em liberdade, a situação política havia mudado muito e parecia calma como nunca, com o poder legal plenamente restabelecido. As milícias paramilitares ficaram privadas de suas bases materiais, já que elas haviam prosperado exatamente no clima de tensão. O NSDAP estava proibido de atuar, bem como as SA e até mesmo o jornal do partido, o Völkisch Beobachter. Parecia que a experiência nacional-socialista chegara ao fim. Mas Hitler ressurgiu como o salvador do partido que se debatia em lutas internas. Em 26 de fevereiro de 1925 o Völkisch Beobachter reapareceu anunciando, no exato lugar do Putsch fracassado, a nova fundação do NSDAP com um editorial intitulado "Um novo começo". Após seu discurso, Hitler tinha conseguido assegurar sua ascendência sobre o partido. Decorridos alguns anos de intensa militância e publicidade, agindo nos estreitos limites da legalidade, o NSDAP conseguiu, nas eleições de setembro de 1930, 6 milhões e 400 mil votos contra os 810 mil da última eleição, saltando de 12 para 107 cadeiras no parlamento. Parecia mesmo possível tomar o poder por meios legais.

Dois anos depois, quando terminou o mandato de Hindenburg, que vinha sendo ampliado artificialmente através de medidas legislativas por conta do medo de que os partidos extremistas chegassem ao poder, não houve como evitar a realização de novas eleições presidenciais. Havia três concorrentes certos, o marechal Hindenburg, concorrendo à reeleição; Ernst Thälmann, representando a esquerda comunista; e Theodor Düesterberg, candidato da extrema direita burguesa. Depois de muita hesitação, Hitler apresenta sua candidatura. A social-democracia, sem muita opção, decidiu apoiar Hindenburg, considerando que a catástrofe seria ainda maior com a vitória de Hitler. Apesar do otimismo dos militantes do NSDAP, o resultado das

\footnotetext{
${ }^{55}$ Idem, ibidem, p. 250.
} 
eleições de 13 de março de 1932 deram ampla vitória a Hindenburg (49,6\% dos votos), com Hitler em segundo (30,1\%), Thälmann em terceiro $(13,2 \%)$ e Düesterberg em último $(6,8 \%)$. De qualquer forma, sem a maioria absoluta, era necessário realizar um segundo turno. O NSDAP estava abalado com a derrota no primeiro turno e desesperançoso com as perspectivas da nova votação, mas Hitler permanecia inabalável, crente de que seria o instrumento de Deus para libertar a Alemanha. Contudo, mesmo após uma campanha intensa de propaganda e dezenas de comícios, o resultado das eleições marcadas para o dia 10 de abril dariam a vitória a Hindenburg, por $53 \%$ dos votos (equivalente a 20 milhões), enquanto Hitler conseguira 36,7\%. Mas como bem notou Emil Ludwig, em uma obra sobre os alemães, escrita ainda no frigir dos ovos, em 1941:

\footnotetext{
"O fato da chefia do Exército - e mais tarde a do Reich - ter ido parar às mãos do marechal von Hindenburg foi conseqüência dum acaso fatal, que custou ao povo alemão duas das maiores desgraças de sua história, porque foi Hindenburg quem perdeu a guerra e quem entregou o poder aos nazistas" ${ }^{, 56}$.
}

Após ter sido reeleito, Hindenburg demite, em 30 de maio de 1932, seu chanceler Brüning, indicando para o seu lugar Franz von Papen, descendente de uma família nobre. As SA, que haviam sido proibidas por Hindenburg, foram postas de volta na legalidade e, logo em seguida, não por coincidência, recomeçaram os confrontos de rua. Na tentativa de domar o NSDAP, Papen ofereceu a Hitler a vice-chancelaria, mas este recusou a oferta com irritação e pouco depois, diante do apelo de Hindenburg, recusou seu apoio ao governo. E era impossível governar sem o apoio do partido de Hitler. No dia 3 de dezembro de 1932 Papen se retira da chancelaria, que passa a ser ocupada pelo general von Schleicher, que não durou sequer dois meses no cargo. Enquanto isso, von Papen, que ainda gozava da confiança do presidente, articulava junto a Hindenburg um governo que contasse com Hitler como chanceler e ele próprio como vice-chanceler. Mesmo relutante, Hindenburg cedeu em 29 de janeiro de 1933, demitindo Schleicher e entregando a Hitler a chancelaria. Estava aberto o caminho para o Estado totalitário.

Como já pudemos notar, os mesmos transtornos políticos causados pela derrota alemã na Primeira Grande Guerra e o caos daí decorrente não só conduziram um partido

\footnotetext{
${ }^{56}$ Ludwig, E. Os alemães: dupla história duma nação, p. 324.
} 
extremista ao poder como fomentaram o desenvolvimento do ocultismo nesse período sobre as bases construídas ao longo do final do século XIX e início do século XX. O desenvolvimento da astrologia, por exemplo, nesse período que antecedeu a ascensão do nazismo, representava uma tentativa de encontrar alguma ordem nos destroços de um mundo prestes a cessar de existir. $\mathrm{Na}$ verdade, as ciências ocultas como um todo cumpriam essa função.

O próprio Lanz von Liebenfels chegou a embarcar no renascimento astrológico da Alemanha, que por sua vez devia-se a um impulso fornecido pela teosofia. O livro de Otto Pöllner - Astrologia Mundana - era uma obra de "astrologia política" que traçava o horóscopo de Estados, povos e cidades na intenção de determinar seus destinos. Editado pela Casa Editorial Teosófica de Leipzig, em 1914, a obra foi resenhada por Lanz, que já em meados de 1915 havia absorvido o suficiente de suas leituras em astrologia para aplicar seus conhecimentos a uma interpretação milenarista muito pessoal acerca da guerra em curso. Lanz então atribuiu a todos os grandes países um planeta e um signo do zodíaco com propriedades que, seguindo sua gnose ario-cristiana, corresponderiam ao seu caráter racial. Para ele, a guerra representava a "plenitude dos tempos" e apontava que a confusão racial crescente e as convulsões sociais geradas por uma nova invasão mongol na Europa prevista para o período de 1960-1988 culminariam em um domínio demoníaco sobre a Terra. Essa profecia apocalíptica neognóstica apontava para a chegada de um novo milênio dominado por uma nova igreja do Espírito Santo que criaria, na Terra, um Estado ariano supranacional com sede em Viena. Essas profecias, publicadas na revista Ostara em 1915, apontavam que o governo dessa nova ordem mundial ficaria a cargo de uma "casta sacerdotal eterna, conhecedora dos segredos da antiga gnose sexo-racista" ${ }^{, 57}$.

A quiromancia e a caracterologia racistas também prosperavam, e o exemplo de Issberner-Haldane, que visitou o Brasil no começo do século XX, é bastante curioso. Nascido em 1886 em Kohlberg, teve sua atenção despertada pela quiromancia ainda criança, quando recebeu de presente do irmão mais velho um livro sobre o tema. Depois de algum tempo servindo no exército e depois trabalhando nos negócios de tabaco de um tio, ele consegue escapar da Alemanha, cuja cultura lhe desagradava, e emigrar para a Austrália. E é nessa viagem que ele entra em contato com as idéias racistas e antisemitas, como foi o caso de um escultor genovês (Paragini), que lhe fala da importância

\footnotetext{
${ }^{57}$ Goodrick-Clarke, Las oscuras raices del nazismo, p. 138.
} 
dos traços raciais para sua arte enquanto nega qualquer criatividade aos judeus, e do doutor Jefferson, um escocês interessado na ariosofia de Lanz. Ele se estabelece na Austrália, trabalhando em diversas granjas, até 1912, quando viaja para a América do Sul. No Rio de Janeiro ele nota que os bordéis estavam cheios de jovens com traços arianos, que ele interpreta como uma conspiração judaica mundial para rebaixar as mulheres de raça superior. Do Rio, ele segue para Manaus e de lá para os Andes, onde experimenta o transe místico e recebe alguma instrução esotérica de Devaswara Lama, um sábio persa itinerante. Depois retorna à Austrália, onde trabalha até 1914 antes de prosseguir viagem para os Estados Unidos, com a intenção de visitar alguns parentes na Alemanha antes disso. Nesse retorno, ele se desvia de seu caminho em Colombo para conhecer a cidade sagrada de Benarés, onde encontra um yogi chamado Ramanchiro, que, através de suas visões, relata a Issber-Haldane cenas de suas vidas passadas ao longo da antiguidade e da idade média. Já na Alemanha, tem início a Grande Guerra e ele é detido e enviado a campos de prisioneiros por quatro anos, como cidadão australiano. Livre em novembro de 1918, ele inaugura em Berlim um consultório de quiromancia e aí faz amigos no interior da cultura ocultista do pós-guerra. Em 1926 ele começa a trabalhar na revista trimestral Die Chiromantie, que no final de 1929 foi absorvida pelo editor Herbert Reichstein, membro da ONT. Dois anos antes, o próprio Issberner-Haldane já se juntara á Ordem dos Novos Templários, logo após conhecer $\operatorname{Lanz}^{58}$.

Reichstein converteu-se em editor de Lanz von Liebenfels em 1925 e coordenava uma associação que congregava os ocultistas interessados nas ciências caracterológicas e nas artes adivinhatórias - obviamente que a partir de um viés racista - o que incluía a astrologia, grafologia, quiromancia e a psicofisiognomia. Delineando os objetivos da associação, Reichstein apontava que por conta do caos gerado pela derrota alemã na guerra, era necessária uma ciência capaz de preparar adequadamente os indivíduos para o seu destino, negando que estivesse fazendo adivinhações, mas determinando o caráter das pessoas, deduzindo daí informações sobre os possíveis resultados das ações individuais em um mundo cada vez mais complexo, que exigia decisões cruciais desses indivíduos. No final de 1925, Reichstein inicia a publicação de uma série de livros que divulgavam a obra de Lanz e no ano seguinte sua associação ocultista passa a ser conhecida como Sociedade Ariosófica ${ }^{59}$.

\footnotetext{
${ }^{58}$ Idem, ibidem, p. 211-212.

${ }^{59}$ Idem, ibidem, p. 213-214.
} 
Em 1928 a Sociedade Ariosófica ganha um importante colaborador na figura de um imigrante russo, cuja decepção com o bolchevismo lhe dá a certeza de que o mundo era refém de uma conspiração representada por judeus, maçons e bolcheviques, cujo plano estava exposto nos Protocolos dos Sábios de Sião. Gregor Schwartz-Bostunitsch nascera em Kiev em 1883 e depois da Revolução Russa, que encerrou sua carreira acadêmica e literária (ele fôra professor de História da Literatura e Teatro no Instituto Lisenko) passou a ativista anti-bolchevique, quando foi preso e condenado à morte. Conseguindo fugir para a Bulgária, ele escapa da sentença de morte e parte em busca de novos valores que o conduziriam ao ocultismo. Após converter-se à antroposofia em 1923, já em 1929 ele denunciava Rudolf Steiner como mais um agente da conspiração mundial judeu-maçônica.

O encontro com Herbert Reichstein aconteceu em 1926, em Düsseldorf, e este reconheceu rapidamente a vocação mística de Schwartz-Bostunitsch, assegurando sua colaboração na Sociedade Ariosófica como um especialista acerca da relação entre a alma russa e a germânica. Mas além do movimento ariosófico, Schwartz-Bostunitsch também estava ligado aos círculos nazistas. Tendo trabalhado, na década de 1920, para Alfred Rosenberg em sua agência de notícias Weltdienst, e apesar de seus problemas de saúde agravados pela idade avançada, esse velho místico viajava por toda a Alemanha proferindo conferências em organizações nazistas acerca de conspirações arquitetadas por judeus e maçons, expressando uma dedicação fanática à missão racial alemã e às SS. Sua dedicação foi recompensada quando em 1944, com o regime nazista à beira do colapso, e por recomendação pessoal de Himmler, o professor honorário das SS foi promovido a SS-Standartenführer (coronel) ${ }^{60}$.

Após a crise de 1929, Reichstein também passou a interessar-se pelo partido nazista no rastro do precedente aberto por Lanz, que a partir de 1925 havia ficado entusiasmado com os regimes de direita na Espanha, Itália e Hungria. Suas publicações da época contavam com horóscopos cabalísticos dirigidos ao NSDAP e a Adolf Hitler. Para ele, a república alemã, que estava sob a influência de Saturno e das forças da magia negra, teria em Hitler e em seu partido - inspirado pela cultura ariosófica - um instrumento divino para o renascimento da Alemanha. Com a ascensão do nazismo ao poder, Reichstein transfere o centro de suas atividades para Berlim, onde publica uma revista (Arische Rundschau - Revista Ária) de caráter racista que atacava a franco-

\footnotetext{
${ }^{60}$ Goodrick-Clarke, Las oscuras raices del nazismo, p. 215-216.
} 
maçonaria, Roma e os judeus, seguida de uma série de livros sobre a "sabedoria do povo" (1934-1935) onde pregava uma religião do "parentesco de sangue"61. Sua atividade mística prosseguiu até 1944, quando ele morre em Freiburg às vésperas da catástrofe alemã que ele nunca conseguira prever.

\section{O misticismo de Heinrich Himmler e o mago Wiligut}

Mas ainda falta nessa cadeia de influências "indiretas" sobre a mitologia nazista a ação de um personagem capaz de exercer uma influência pessoal e direta sobre a ideologia mística do III Reich. Conhecido como o Rasputin do Reichsführer-SS Heinrich Himmler (um dos mais importantes membros do movimento nacionalsocialista), o mago Karl Maria Wiligut (1866-1946) cumpriu essa função. Suposto portador de memórias ancestrais acerca das tradições germânicas antigas, Willigut dirigiu, entre 1933 e 1939 o departamento de investigações pré-históricas da SS. É a ele que devemos retornar quando pretendemos compreender a ligação da SS com o castelo Wewelsburg, e a adoção por parte dela de cerimoniais de pureza racial. Nascido em Viena, em 1866, Wiligut era filho e neto de oficiais do exército austríaco e, dando prosseguimento a uma tradição familiar ingressou cedo, aos 14 anos, na Escola Imperial de Cadetes, sendo incorporado ao regimento de infantaria em 1884. Quatro anos mais tarde Wiligut já era sub-tenente, em 1892 chegou a tenente, e depois de onze anos, em 1903, chegaria a capitão. Apesar da carreira militar, Wiligut nutria certa ambição literária que o levou a publicar versos de características românticas, onde celebrava a natureza e explorava os temas mitológicos sob um viés explicitamente nacionalista, como foi o caso de Seyfrieds Runen (1903). O livro, editado por Friedrich Schalk, mesmo editor de alguns dos livros de Guido von List, refletia alguns dos estudos folclóricos de List. Logo após o início da Primeira Grande Guerra, Wiligut já havia alcançado o posto de tenente coronel e logo alcançaria o título de coronel, em 1917, graças às suas condecorações por bravura durante a guerra.

Apesar de Wiligut ter se vinculado em 1889 a uma loja de características maçônicas, sua importância para os grupos völkisch e a SS “descansava em sua reputação como último descendente de uma grande linhagem de sábios germânicos, os

\footnotetext{
${ }^{61}$ Idem, ibidem, p. 220-221.
} 
Uiligotis de Asa-Uana-Sippe, que remontava a uma era pré-histórica remota". Wiligut reforçava a lenda afirmando possuir "uma memória clarividente ancestral que o habilitava a recordar a história e as experiências de sua tribo ao longo de milhares de anos". Ele dizia receber instruções, através das runas, de seu avô Karl Wiligut, morto em 1883. Os caminhos desse velho mago e a tradição pagã teriam se cruzado com Theodor Czepl, membro da Ordem dos Novos Templários (ONT), em 1908 através dos círculos ocultistas de Viena, que incluíam vários outros membros da ONT. Através dessas ligações do pré-guerra, Lanz von Liebenfels incumbiu Czepl a retomar o contato com Wiligut, reaproximação que se efetivou no inverno de 1920-1921 através de encontros que foram registrados em memorandos preparados para a ONT. Nesses encontros Czepl chegou a ficar hospedado por semanas na casa de Wiligut, que lhe contou ser o portador de uma linhagem secreta da realeza germânica, provando essa pretensão com provas na forma de selos familiares e documentos sobre heráldica. E muito de acordo com as revelações também inspiradas de Guido von List, ele descreveu, com base em suas intuições clarividentes, as práticas religiosas e a organização militar dos antigos germanos. Wiligut também sustentava "que a Bíblia teria sido escrita originalmente na Alemanha, evidentemente se identificava com uma religião irminista que diferia do wotanismo e se opunha a ele, celebrando um deus germânico chamado Krist que mais tarde a religião cristã havia purificado e apropriado como seu próprio salvador" ${ }^{\prime 62}$.

Essas crenças já estavam solidificadas por volta de 1920 na mente de Wiligut, mas sua elaboração posterior pode ser compreendida através dos escritos de um de seus discípulos austríacos, Ernst Rüdiger (1885-1952), que conheceu o mago durante a guerra. De acordo com Rüdiger, Wiligut atribuía aos germanos uma cronologia muito mais antiga que aquela permitida pelos pesquisadores da época, fazendo-a remontar a 228.000 a.C., tempo em que na Terra habitavam gigantes, anões e outras criaturas místicas e no céu havia três sóis. Para Wiligut a história começava quando seus ancestrais, os Adler-Wiligoten, restabeleceram a paz após longos períodos de conflitos, dando origem à "segunda cultura Boso", período em que teria sido fundada, 78.000 anos antes de Cristo, a cidade de Arual-Jöruvallas (Goslar), enquanto que os milênios seguintes veriam uma série de lutas tribais e migrações populacionais rumo a fantásticos continentes desaparecidos, sempre presentes na tradição teosófica. Foi então que, por

${ }^{62}$ Idem, ibidem, p. 226-227. 
volta do ano 12.500 a.C., a religião irminista de Krist teria sido proclamada pelos germanos, tendo sobrevivido como religião universal até um cisma originado pelos wotanistas. Com a crucificação de Baldur-Chrestos (um profeta sagrado do irminismo) por wotanistas, a tensão religiosa entre wotanistas e irministas teria atingido seu clímax, isso por volta de 9.600 a.C.. Ao que parece, apesar do inconveniente da crucificação, o profeta irminista teria conseguido fugir para a Ásia e a religião teria sobrevivido até a destruição por wotanistas do centro sagrado irminista em Goslar, em 1200 a.C. . Resistindo à extinção, os irministas teriam fundado um novo templo em Exsternsteine, que por sua vez foi também tomado pelo inimigo em 460 d.C. e depois conquistado por Carlos Magno no século IX na campanha contra o paganismo saxão. Os ancestrais de Wiligut teriam sido "reis sábios" cuja linhagem remontaria à união dos Asen (deuses do ar) com os Wanen (deuses da água). Alguns membros da tribo dos Wiligotis foram reis em Burgenland, mas enquanto Carlos Magno levava adiante sua perseguição contra os pagãos do norte da Germânia, os Wiliguts dessa área conseguiram fugir do domínio franco para as ilhas Faeroe e dali para a Rússia central. Aí eles fundaram a cidade de Vilna, que se converteria na capital de um vasto império gótico, destruído graças à hostilidade da Rússia e dos cristãos. Em 1242 sua família teria imigrado para a Hungria conseguindo libertar-se, ao menos temporariamente, da vigilância da igreja católica e dos wotanistas, mais preocupados com as invasões tártaras do que com a ameaça irminista ${ }^{63}$.

O conteúdo dos delírios persecutórios de Wiligut no começo da década de 1920 deve-se a essa clarividência que ligava sua família à origem dos povos germânicos, origem essa que remontava aos tempos míticos, povoado de seres mágicos. Ele estava convencido de que era vítima da perseguição secular empreendida pela igreja católica, os judeus e os franco-maçons, contra sua tribo e a fé irminista; no plano social, tal conspiração teria acarretado a derrota alemã na Primeira Guerra Mundial e o colapso do império Habsburgo. Na intenção de divulgar suas crenças, Wiligut fundou uma liga anti-semita e um periódico (Escova de Ferro) que atacava judeus e franco-maçons. Os problemas de saúde de Wiligut vinham se agravando desde a morte de seu único filho homem (ainda na infância), deixando-o apenas com duas meninas, o que rompia a cadeia de sucessão de seus antepassados impedindo que a herança tradicional - o conhecimento secreto dos Wiligotis - pudesse ser passado adiante. Em 1924, graças a

\footnotetext{
${ }^{63}$ Idem, ibidem, p. 227-228.
} 
seus delírios, Wiligut precisou ser internado - contra a sua vontade - em um hospício em Salzburgo, permanecendo recluso até o início de 1927. O laudo médico fazia referência à sua violência doméstica, incluindo ameaças de morte a sua mulher, projetos grandiloquentes, comportamento excêntrico e interesses ocultistas, antes de diagnosticar um quadro de esquizofrenia que envolvia megalomania e delírios paranóides ${ }^{64}$.

Apesar de sua internação forçada, Wiligut continuou se correspondendo com seus discípulos da Áustria e com vários membros da ONT e da sociedade Edda, apoio que lhe possibilitou retornar às suas atividades intelectuais como ocultista. Mas para tanto, em 1932, ele precisou abandonar sua família e a Áustria, estabelecendo-se em um subúrbio de Munique, onde prosseguiu suas investigações sobre a herança ancestral, convertendo-se rapidamente em um dos principais ocultistas das runas na Alemanha, reconhecimento impulsionado pelo interesse da Sociedade Edda e sua revista Hagal. E foi nessa época que Wiligut conheceu o Reichsführer-SS Heinrich Himmler, então braço direito de Hitler. A afinidade entre esses dois homens foi imediata. Wiligut, a partir de suas próprias esperanças apocalípticas, simpatizava com a revolução nazista de janeiro de 1933, enquanto que Himmler, movido por suas próprias fantasias místicas, ficou muito impressionado com as memórias do remoto passado alemão das quais Wiligut era o portador. A convite de Himmler e sob o pseudônimo de Karl Maria Weisthor, Wiligut passou a dirigir o Departamento de Pré-História e História Arcaica, pertencente à Secretaria de Raça e Colonização, que por sua vez estava vinculada à SS. Suas atribuições nesse departamento parecem ter sido "entregar por escrito exemplos de sua memória ancestral, discutir suas tradições familiares com Himmler e estar disponível para comentar temas relacionados com a pré-história" ${ }^{65}$. No ano seguinte Weisthor (ou seja, Wiligut) já havia sido promovido por Himmler ao posto de SS-Oberführer (tenente-brigadeiro das SS).

Em agosto de 1934, pouco antes da promoção, Weisthor apresentou Himmler a Günther Kirchhoff, um membro da Sociedade List e sócio de um tal Tarnhari, indivíduo igualmente portador de memórias ancestrais e que se dizia (pasmem) descendente da tribo dos Wölsungen. Pois bem, Kirchhoff também era um aficcionado pela pré-história alemã, sobretudo na sua versão mística e mitológica como divulgavam List e Wiligut, além de possuir suas próprias "visões" ou "especulações" sobre o tema. De acordo com ele, a antiga Europa havia sido governada por três grandes reis: Uiskunig, de Goslar;

\footnotetext{
${ }^{64}$ Idem, ibidem, p. 229.

${ }^{65}$ Idem, ibidem, p. 230.
} 
Ermanrich de Vineta e o rei Arthur de Stonehenge. A estes reis estava subordinado Günther Barba-ruiva, cuja tribo, tendo migrado para a Escócia em 800 a.C. passou a ser conhecida como clã Kirkpatrick, e Kirchhoff “deduzia seu próprio parentesco de sangue tanto com a tribo Günther como com a de Kirkpatrick baseando-se nas etimologias de List" ${ }^{\prime 66}$.

E foram essas análises clarividentes, bem como outras elucubrações acerca dos nibelungos e dos rosacruzes que Kirchhoff entregou a Himmler e à lendária fundação "científica" Ahnenerbe (herança dos antepassados) entre os anos de 1936 e 1944. Porém, os acadêmicos da Ahnenerbe, após analisarem os dados e as conclusões de algumas das investigações de Kirchhoff em 1937, informaram a seus superiores que nas análises desse místico havia muito de ocultismo listiano mas pouco de investigação séria acerca da pré-história. De fato, Kirchhoff, apoiado por Weisthor/Wiligut, interpretara os achados no vale de Murg, perto de Baden-Baden (inscrições, cruzes, esculturas, runas e outros símbolos), e sobretudo na área de Schloss Eberstein como parte de um gigantesco complexo irminista. Essa metodologia de pesquisa geográfica, que apelava para um simbolismo oculto, impressionou e influenciou as pesquisas subseqüentes de Wiligut, mas exasperou os "cientistas" da pré-história. O caso foi parar nas mãos de Himmler, que se deixou convencer pelas visões de Kirchhoff, insistindo para que a Ahnenerbe continuasse suas investigações com o auxílio desse ocultista inspirado. Assim, "Kirchhoff seguiu escrevendo à Ahnenerbe durante a guerra. A última carta sua que se conhece, dirigida às autoridades nazistas, é um tratado ocultista de trinta páginas sobre a causa dos revezes alemães na guerra, enviada a Adolf Hitler por intermédio de Himmler a fins de 1944"67.

A personalidade de Himmler, facilmente influenciada por especulações ocultistas e imagens heróicas dos tempos medievais, nos conduzirá, sob a influência de Wiligut, a outra aventura romanesca do Reichsführer-SS: a escolha do castelo Wewelsburg como centro do cerimonial das tropas SS. Ao longo da campanha eleitoral de 1933, Himmler ficara emocionado com a atmosfera do bosque de Teutoburger e do castelo de Grevenburg, onde a comitiva de Hitler ficou hospedada. Influenciado por essa experiência, ele tem a idéia de encontrar um castelo nessa região que pudesse converter em sede da SS. Após visitar alguns castelos na companhia de sua equipe pessoal, alguns meses depois, no final de 1933, ele se decide por Wewelsburg, e em

\footnotetext{
${ }^{66}$ Idem, ibidem, p. 231.

${ }^{67}$ Idem, ibidem, p. 233.
} 
agosto do ano seguinte o castelo já pertencia oficialmente à SS, convertendo-se em um centro de doutrinação ideológica dos oficiais da SS, ligado à Secretaria de Raça e Colonização. Mas em fevereiro de 1935, Wewelsburg já estava sob controle direto de Himmler e de sua equipe. Nas visitas empreendidas pelos arredores em busca de um castelo, o Reichsführer estava em companhia de Weisthor/Wiligut, e quando Wewelsburg foi adquirido ele lhe disse que o castelo estaria destinado a converter-se em uma fortaleza alemã no caso de um conflito futuro entre a Ásia e a Europa. Essa idéia, baseada em uma antiga lenda da Westfália expressada em um poema romântico do século XIX, descrevia a visão de um pastor onde um grande exército do leste era vencido pelo exército do oeste. Weisthor levou essa lenda ao conhecimento de Himmler “afirmando que Wewelsburg era o 'bastião' contra o qual se abateria essa 'nova invasão huna' em cumprimento da antiga profecia"68. E Karl Wolff, membro da equipe de Himmler, recordava que o Reichsführer ficara muito comovido com essa visão que se coadunava com sua própria crença de que no futuro, dentro de uns cem ou duzentos anos, as SS seriam a defesa da Europa no conflito leste-oeste que aconteceria no futuro.

Weisthor/Wiligut, ao longo de suas visitas ao castelo Wewelsburg, fez amizade com Manfred von Knobelsdorff, comandante do castelo, que rapidamente ficou entusiasmado com suas conversas com o velho mago e desejou reviver a fé irminista através de rituais realizados no castelo, o que incluía rituais pagãos de casamento para os oficiais, cujas cerimônias contavam com Wiligut empunhando um bastão de marfim gravado com runas. Além dos rituais de matrimônio, celebravam-se também festivais de primavera e solstício. O manual das SS pregava o seguinte:

\begin{abstract}
"No dia do solstício do inverno, o sol ergue-se novamente de sua sepultura invernal. Este evento anual era celebrado como o maior dos festivais pelos nossos antepassados. Avançavam eles na noite conduzindo tochas para libertar o sol da servidão da morte invernosa e consideravam-no um jovem herói que vinha despertá-los e libertá-los do sono quase mortal... Na véspera do Natal, os principais ingredientes devem ser a carpa, o ganso assado e o javali - retirados respectivamente dos domínios da água, da terra e do ar" ${ }^{\circ 9}$.
\end{abstract}

Enquanto isso, prosperava a amizade com Himmler, que chegou a encomendar a Wiligut o desenho do anel de honra das SS, a ser utilizado como símbolo de obediência

\footnotetext{
${ }^{68}$ Idem, ibidem, p. 234.

${ }^{69}$ Grunberer, Richard. A história da SS, p. 42.
} 
e lealdade. Outorgado por Himmler em pessoa, o anel contava com o desenho de uma caveira, uma suástica e diversas runas. A importância do anel e sua vinculação com Wewelsburg era tão marcante que em 1938 "Himmler declarou que os anéis de todos os homens e oficiais das SS mortos deveriam ser devolvidos para ser conservados em uma arca no castelo como expressão simbólica de sua comunidade duradoura na ordem" ${ }^{\text {"70 }}$. Quanto a Wiligut, seu objetivo era recriar na Alemanha a religião irminista através da nacionalização das propriedades da igreja católica e a conservação dos monumentos antigos que supostamente comprovavam a história de sua religião.

Um outro personagem dessa história de investigações arqueológicas mirabolantes é o jovem historiador Otto Rahn (1904-1939), de quem já falamos antes. Goodrick-Clarke confirma o interesse de Rahn pela história medieval dos cátaros e a lenda do Graal. Graças às especulações criadas em torno da heresia cátara, Rahn conseguiu incorporar-se, em 1935, ao departamento de Weisthor/Wiligut, e graças ao interesse de Himmler por seu trabalho acerca da tradição religiosa germânica, no ano seguinte ele já havia ingressado formalmente nos quadros das SS, vindo a renunciar a seu posto de forma inexplicável em 1939. O mesmo aconteceu com Wiligut, no mesmo ano, mas por motivo de saúde (problemas psiquiátricos). O velho mago devolveu a Himmler o anel sagrado das SS e, mesmo afastado de suas atividades, foi cuidado por membros da equipe de Himmler enquanto o regime nazista perdurou. Wiligut sobreviveu para ver ruir o seu sonho de uma fé irminista ressurgindo na Alemanha e espalhando-se pelo mundo. Morreu em janeiro de 1946.

\section{O Arianismo em Hitler e as influências de Lanz Von Liebenfels e da revista} Ostara

Fazendo eco às críticas correntes na época, Hitler via no domínio dos judeus sobre a imprensa e as artes não só uma tentativa de controle global do povo alemão, mas a intenção de rebaixá-los culturalmente. Os judeus, cuja pureza moral era uma questão discutível, já que eles não eram amantes de banhos e cujas roupas sujas e aparência acovardada eram o retrato fiel da raça, estavam envolvidos, com sua imundície física, onde quer que houvesse uma impudência na vida cultural alemã: "Quem, cautelosamente, abrisse o tumor haveria de encontrar, protegido contra as surpresas da

\footnotetext{
${ }^{70}$ Idem, ibidem, p. 235.
} 
luz, algum judeuzinho. Isso é tão fatal como a existência de vermes nos corpos putrefatos",71.

A idéia da degeneração progressiva, típica daqueles tempos, tinha como vilões, no pensamento de Hitler, tanto a sífilis quanto o envenenamento do sangue nacional, argumentos que conduziam sempre aos judeus. A causa primária da devastação pela sífilis era a "prostituição do amor":

\footnotetext{
"Não! Não se pode negar, por demasiado evidente, a triste realidade de que o povo das nossas grandes cidades cada vez mais se prostitui e, justamente por isso, aumentam as devastações da sífilis. As conseqüências dessa epidemia geral podem ser examinadas nos hospícios e infelizmente também nas crianças. Sobretudo estas são o mais triste resultado do constante e progressivo infeccionamento da nossa vida sexual. Nas doenças das crianças são evidentes as taras dos pais" ${ }^{\text {,72 }}$.
}

Esse pecado contra o sangue e a raça poderiam resultar no fim da humanidade. $\mathrm{O}$ puritanismo de Hitler, que reflete seu horror diante do sexo, conduzia porém a um objetivo mais elevado: a purificação e a sobrevivência da raça. Os casamentos, argumentava ele como qualquer bom cristão seria capaz de fazer, deveriam ser estimulados para evitar a prostituição da juventude, mas, sobretudo, porque sua principal função seria a multiplicação e a conservação da raça. O culto ao corpo deveria substituir o culto ao intelecto, tão valorizado pelos judeus, porque a covardia residiria na fraqueza física e a negligência em relação à formação física daria origem ao desejo sexual antes do tempo. O sujeito, preso em seu gabinete de estudo e levando uma vida sedentária, estaria mais predisposto a ceder a seus instintos sexuais que o jovem praticando uma atividade física. Por isso:

"O conjunto da educação deveria ser organizado de maneira que todo o tempo disponível da mocidade fosse empregado na sua cultura física. Nos tempos que convêm, a mocidade não tem o direito de errar pelas ruas e cinemas, fazendo distúrbios, cumprelhe, depois da faina diária, exercitar-se fisicamente para, quando entrar na vida, apresentar a resistência necessária. Prepará-la para isso deve ser o objetivo da educação e não simples aquisição da chamada cultura intelectual" ${ }^{, 73}$.

\footnotetext{
${ }^{71}$ Hitler, A. Minha Luta, p. 47.

${ }^{72}$ Idem, ibidem, p. 185.

${ }^{73}$ Idem, ibidem, p. 189.
} 
Para combater a prostituição, deve-se combater inicialmente as razões espirituais nas quais ela se funde, aponta Hitler mais a frente, e a maneira de fazer isso seria livrando o povo do "lixo da intelectualidade", o que nos conduz novamente aos judeus, sabidamente os representantes da intelectualidade alemã. Para Hitler, "um povo de sábios, fisicamente degenerados, torna-se fraco de vontade e transforma-se em um corpo de pacifistas covardes que nunca se elevará às grandes ações e nem mesmo poderá assegurar-se a existência na terra" ${ }^{, 74}$.

Inspirado pelo darwinismo social, Hitler argumenta que o cruzamento entre seres em situação desigual na escala biológica produziria uma descendência incapaz de competir por sua sobrevivência. Tal união seria mesmo contrária à vontade da natureza, que se defenderia privando esses bastardos da capacidade de procriação ou limitando a fecundidade de seus descendentes. Como o papel do mais forte seria o de dominar, ele não deveria se misturar com os fracos, sacrificando assim a sua grandeza. Em resumo, o cruzamento das raças acarretaria: “A) relaxamento do nível da raça mais forte; B) regresso físico e intelectual e, com isso, o começo de uma enfermidade, que progride devagar, mas seguramente. Provocar semelhante coisa não passa então de um atentado à vontade do criador" ${ }^{, 75}$.

Por isso a missão do Estado nacionalista seria colocar a questão racial como um problema dominante, coisa que os judeus sempre souberam fazer, pois abusando da tolerância dos arianos para os demais credos, a religião mosaica teria conseguido conservar a raça judaica. Sua doutrina (dos judeus) seria um conselho para a conservação da pureza do sangue.

O rancor contra o "espírito da humanidade individualista", que permite que os fracos e os degenerados sobrevivam, que Hitler identifica com o espírito burguês (e portanto também judeu) de "igualdade" de todos os homens, choca-se com a idéia de uma "humanidade natural" capaz de substituir a debilidade pela força. E o sucesso de determinados indivíduos da raça inferior, coisa que acontecia com alguma raridade, mas acontecia, Hitler entendia apenas como "adestramento":

\footnotetext{
"De tempos em tempos, os jornais ilustrados comunicam aos seus leitores burgueses que, pela primeira vez, aqui ou ali, um negro tornou-se advogado, professor, pastor, primeiro tenor, etc. Enquanto a burguesia sem espírito fica admirada de um tão
}

\footnotetext{
${ }^{74}$ Idem, ibidem, p. 309.

${ }^{75}$ Idem, ibidem, p. 213.
} 
maravilhoso adestramento e, cheia de respeito por esse fabuloso resultado da atual arte de educar, o judeu esperto compreende que daí será possível tirar mais uma prova da justeza da teoria que pretende inculcar no público, segundo a qual todos os homens são iguais. Não se apercebe esse desmoralizado mundo burguês que se trata de um ultraje à nossa razão, pois é uma criminosa idiotice adestrar, durante muito tempo, um meiomacaco, até que se acredite que ele se fez advogado, enquanto milhões de indivíduos pertencentes às mais elevadas raças devem permanecer em uma posição inteiramente digna, se tem em vista a sua capacidade" ${ }^{, 76}$.

Não convém perder tempo adestrando meio-macacos porque as raças verdadeiramente inteligentes, se o Estado lhes conferisse o estímulo e a oportunidade, chegariam muito mais longe. Também não se deve incentivar que indivíduos doentes procriem dando origem a outros indivíduos igualmente doentes, e assim Hitler justifica suas aspirações eugênicas:

\footnotetext{
"tornar impossível que indivíduos doentes procriem outros mais doentes é uma exigência que deve ser posta em prática de uma maneira metódica, pois se trata da mais humana das medidas. Ela poupará a milhões de infelizes desgraças que não mereceram e terá como conseqüência a elevação do nível da saúde do povo. A firme resolução de enveredar por esse caminho oporá também um dique às moléstias venéreas. Nesse assunto, quando necessário, deve-se proceder, sem compaixões, no sentido do isolamento dos doentes incuráveis. Essa medida é bárbara para os infelizes portadores dessas moléstias, mas é a salvação dos coevos e pósteros. O sofrimento imposto a um século livrará a humanidade de sofrimento por milhares de anos" ${ }^{, 77}$.
}

Aqui, pelo menos, ainda não havia a idéia declarada da eliminação física como solução para o problema dos degenerados, tratava-se apenas de impedi-los de procriar. Com relação aos judeus, a idéia também consistiria no isolamento sexual e na diminuição de sua influência sobre a cultura mediante ação do Estado, que por sua vez deveria agir substituindo a idéia de "liberdade individual" pela de "conservação da raça". Ele nos lembra que, de acordo com a concepção racista, não haveria igualdade entre as raças e por isso seu dever "conforme a eterna vontade que governa este universo" seria a de "promover a vitória dos melhores, dos mais fortes e exigir a subordinação dos piores, dos mais fracos",78.

\footnotetext{
${ }^{76}$ Idem, ibidem, p. 324.

${ }^{77}$ Idem, ibidem, p. 190.

${ }^{78}$ Idem, ibidem, p. 291.
} 
O objetivo desse ideal eugênico era impedir o envenenamento do sangue, principal responsável pelo perecimento das primitivas raças criadoras. E Hitler considera desnecessário discutir quais raças teriam sido as depositárias da cultura humana, ou seja, as fundadoras da humanidade. Era inequívoco, a partir das criações na arte, na técnica e na ciência, que a "criação" seria um produto exclusivo do ariano, fundador exclusivo da humanidade superior. Sem ele, a civilização humana chegaria ao fim. Sua mitologia do desenvolvimento das civilizações passa necessariamente pelo seu arianismo: para Hitler, tribos arianas, ao subjugarem povos estrangeiros, desenvolveriam, graças a suas capacidades superiores, grandes civilizações, mas ao pecarem contra a pureza conservadora do sangue, misturando-se com os habitantes subjugados, acabariam degenerando. O ariano, afirma, "sucumbiu com a mistura racial; perdeu, aos poucos, cada vez mais, sua capacidade civilizadora, até que começou a se assemelhar mais aos indígenas subjugados do que a seus antepassados, e isso não só intelectual como fisicamente, ${ }^{, 79}$.

E é assim que os judeus pretendem estragar os fundamentos raciais dos outros povos. Ele que não possui um Estado com limites definidos e nem cultura própria, por isso vive como um parasita, um micróbio nocivo no interior dos Estados alheios, e como um parasita que mata seu hospedeiro, o Estado que o hospeda vai sendo exterminado. Hitler critica no judeu a exploração do povo e a destruição da monarquia (para quem ele empresta dinheiro e mantém endividada) com a intenção de substituí-la por um sistema de governo mais de acordo com suas mentiras acerca da "igualdade dos homens", isto é, o parlamentarismo e seu correlato: a democracia triunfante. As considerações raciais que ele ignora também fazem parte desse plano de destruição de todas as nações. E em todo lugar, Hitler vê um judeu à espreita, esperando a oportunidade para corromper o sangue dos arianos:

“O judeuzinho de cabelos negros espreita, horas e horas, com um prazer satânico, a menina inocente que ele macula com o seu sangue, roubando-a a seu povo. Não há meios que ele não empregue para estragar os fundamentos raciais do povo que ele se propõe vencer. Do mesmo modo que, segundo seu plano traçado, vai corrompendo mulheres e mocinhas, também não recua diante do rompimento de barreiras impostas pelo sangue, empreendendo essa obra em grande escala, no país estranho. Foram e continuam a ser ainda judeus os que trouxeram os negros até o Reno, sempre com os mesmos intuitos secretos e fins evidentes, a saber: 'bastardizar' à força a

\footnotetext{
${ }^{79}$ Idem, ibidem, p. 220.
} 
raça branca, por eles detestada, precipitá-la do alto da sua posição política e cultural e elevar-se ao ponto de dominá-la inteiramente" ${ }^{\prime 80}$.

O marxismo, principal concorrente do nacional-socialismo, também militava a favor do enfraquecimento da raça, não apenas por ser uma ideologia judaica, mas por prescindir do respeito pelas personalidades e, sobretudo, por não perceber que a luta não se travava entre classes antagônicas mas entre raças superiores e inferiores.

Mas isso não impedia o movimento nacional-"socialista" de se apresentar, como aponta o próprio nome, como "socialista". Não se tratava entretanto de um movimento orientado para entregar o poder aos proletários no sentido do marxismo, mas, como aponta Franz Newmann, de um “imperialismo proletário racial”. O comunismo oferecia o sonho de uma sociedade sem classes que seria conseguida não escravizando outras nações mas tranformando o sistema sócio-econômico e destruindo a burocracia. $\mathrm{O}$ nacional-socialismo oferecia o marxismo ao proletariado também, porém sem as lutas de classes. Eles não eram instados a lutarem contra a classe governante, mas a juntaremse a ela participando de seu poder e glória convertendo-se em parte do colossal maquinário do Estado. ${ }^{81}$ Ou seja, como notou Leandro Konder, "para elaborar suas concepções, o fascismo foi - pragmaticamente - buscar idéias no campo do inimigo. Numa direita apavorada com a revolução proletária, era natural o impulso de macaqueála, assimilando-a 'desfigurada' para tentar neutralizá-la” ${ }^{, 82}$. Coisa que o próprio Hitler reconhece no Mein Kampf.

Para Hitler, o movimento nacional-socialista deveria incutir o respeito pelas personalidades porque todos os valores humanos residiriam no indivíduo, fonte de poder criador e de todas as idéias e realizações. Assim, o culto à personalidade representaria a condição para a reconquista do poder da raça ariana. E a função do marxismo era exatamente o oposto disso: a destruição de todas as nações que não fossem judaicas, porque o judeu, fingindo compaixão pela sorte dos trabalhadores, por sua miséria e indigência, acabava por angariar sua confiança e em sua campanha para exterminar as pragas sociais fundava a doutrina marxista: "assim cria-se um verdadeiro movimento trabalhista, sob a chefia dos judeus. Aparentam visar à melhoria das

\footnotetext{
${ }^{80}$ Idem, ibidem, p. 240.

${ }^{81}$ Newmann, F. Behemoth: pensamento e ação no nacional-socialismo, p. 220-221.

${ }^{82}$ Konder, L. Introdução ao fascismo, p. 8.
} 
condições dos operários, tendo na mente, porém, em verdade, a escravidão e o aniquilamento de todos os povos que não são judeus" ${ }^{\text {" } 33}$.

Mas a aniquilação dos alemães não estaria nas mãos dos judeus, mas do próprio Hitler, em umas dessas ironias bastante freqüentes na história. Na madrugada do dia 22 de junho de 1941, Hitler decide tomar a mais grave decisão suicida de sua vida ao desatar os últimos nós dos escrúpulos que o mantinham atrelado ao pacto de nãoagressão Ribbentrop-Molotov. Arrancando Mussolini da cama com uma mensagem urgente, ele informa o Duce que iria invadir a Rússia. Tinha início a maior ofensiva militar já vista na história, com mais de 600.000 veículos motorizados, 3.500 blindados e pouco menos de 3.000 aviões. A invasão começou sem qualquer aviso e em pouco tempo mais da metade dos 10.000 aviões russos já haviam sido abatidos. O objetivo da ofensiva contra a Rússia era claro: tratava-se de uma luta entre duas concepções de mundo, e o comunismo, essa terrível ameaça para o futuro, deveria ser destruído. Diferente dos combates no oeste, no leste deveria ser uma guerra de aniquilação criminosa, mesmo para os padrões "normais" de uma guerra comum. Valia tudo, na mais assustadora acepção do termo. Porém, como não é possível confiar totalmente na imaginação do leitor, convém esclarecer do que se trata: assaltar, pilhar, prender judeus, funcionários comunistas, intelectuais, dirigentes políticos e assassiná-los. Sem qualquer consideração para com mulheres e crianças, a campanha na Rússia foi uma prévia do que viria a ser a "solução final". Em poucas semanas o número de prisioneiros de guerra russos já chegava a 600.000, mas a ordem era "não fazer prisioneiros" e, em qualquer guerra, sabemos o que isso significa: escravização por um tempo, seguida de extermínio. A vitória em Kiev pareceu indicar que a guerra havia sido a melhor decisão e que a vitória era inevitável. Até que teve início a tentativa de assalto a Moscou.

Com o outono russo, vieram as chuvas, que castigavam os soldados alemães, agora obrigados a marchar na lama, onde os veículos atolavam e a chegada de suprimentos ficava cada vez mais difícil. Mas o pior ainda estava por vir. Com a chegada do inverno, quando o exército alemão estava a poucos quilômetros da capital, a temperatura despencou para $-50^{\circ} \mathrm{C}$. Apesar das admoestações de seus generais antes do início da ofensiva, Hitler estava convicto de que a guerra estaria decidida antes do inverno, então não haveria necessidade de preparar equipamentos de inverno para os soldados. O combustível dos veículos congelava nos tanques, as armas emperravam por

\footnotetext{
${ }^{83}$ Hitler, A. Minha Luta, p. 237.
} 
estarem igualmente congeladas e havia mais mortos por congelamento do que soldados abatidos em combate. Mas o que está ruim sempre pode piorar: ainda em meio ao frio glacial das proximidades de Moscou, um grupo de elite vindo da Sibéria, especialistas absolutos em combate no frio, chegou à linha de frente. Os generais sugeriam a Hitler um "desvio tático", mas o Führer queria que os soldados resistissem até o último homem, de forma fanática e não importavam as considerações estratégicas que apontavam para a inutilidade desse sacrifício.

As ordens de Hitler representaram a morte de todos os seus soldados, mas ele não estava preocupado com isso. Conta-se que ele teria dito, diante da perspectiva de uma rendição na Rússia ou da retirada das tropas, que

\footnotetext{
"se um dia o povo alemão não for bastante forte nem estiver suficientemente preparado para o sacrifício de dar seu sangue a fim de salvar sua existência, que desapareça e seja destruído por outra potência mais forte do que ele (...). Nesse caso, não derramaria uma só lágrima pelo povo alemão" ${ }^{\circ 4}$.
}

Vemos aí o quanto Hitler foi wagneriano (em sua versão mais schopenhaueriana) até o fim. Os momentos derradeiros da campanha contra a Rússia evocam a "Destruição dos poderes", o Ragnarøkr escandinavo, ou o "fim do mundo". O fio do destino, rompido com a invasão da Rússia, leva Hitler a desejar aquilo que iria acontecer inevitavelmente: a Alemanha arderia em chamas. Como Wotan, ele não queria mais impedir a degradação progressiva do mundo e o crepúsculo dos deuses germânicos. Como notam Adorno e Horkheimer,

\footnotetext{
"Ele [o paranóico] não parece precisar de ninguém e, no entanto, exige que todos se ponham a seu serviço. Sua vontade penetra o todo, nada pode deixar de ter uma relação com ele. Seus sistemas não tem lacunas. Como astrólogo, ele dota os astros de forças que provocam a ruína dos incautos - no estágio pré-clínico, de ego de outrem, e no estágio clínico, de seu próprio ego. Como filósofo, ele transforma a história universal na executora de catástrofes e decadências inevitáveis" ${ }^{\prime 5}$.
}

Mircea Eliade fala de "perfeição dos primórdios" ao referir-se à recordação imaginária de um "paraíso perdido" de beatitude que teria precedido a atual condição humana, algo muito semelhante ao "sentimento oceânico" a que Freud se refere como

\footnotetext{
${ }^{84}$ Fest, J. Hitler, p. 776.

${ }^{85}$ Adorno; Horkheimer. Dialética do esclarecimento, p. 177-178.
} 
uma tentativa de restauração do narcisismo ilimitado e que posteriormente teria se vinculado à religião. $\mathrm{O}$ argumento de Eliade é o de que o decorrer do Tempo implicaria um distanciamento progressivo do "princípio" e consequentemente a perda da perfeição do início. Como "tudo o que dura se desfaz em pó, degenera e acaba por perecer" a plenitude e o vigor seriam encontrados no princípio, mas a plenitude perdida poderia ser periodicamente recuperada. Porém, para que o novo pudesse surgir, o velho precisaria ser destruído:

"Em outros termos, para a obtenção de um começo absoluto, o fim do mundo deve ser radical. A escatologia é apenas a prefiguração de uma cosmogonia do futuro. Mas toda escatologia insiste em um fato: que a Nova Criação não pode ter lugar antes que este mundo seja definitivamente abolido. Não se trata mais de regenerar o que degenerou - mas de destruir o velho mundo a fim de poder recriá-lo in toto. A obsessão da beatitude dos primórdios exige a aniquilação de tudo o que existiu e que, portanto, degenerou após a criação do Mundo: é a única possibilidade de restaurar a perfeição inicial" $" 86$

A batalha final entre entre a raça eleita e os judeus, que conduziria a um mundo purificado faziam parte da mitologia escatológica e milenarista do nazismo. E por muito puco o mito não se tornou realidade.

Pois bem, sempre foi razoavelmente simples (por mais que praticamente todos os historiadores clássicos jamais o tenham feito) vincular diversos elementos da doutrina nacional-socialista à tradição ocultista que se desenvolveu na Alemanha nos séculos XIX e XX. E um nome em especial, o de Heinrich Himmler e de sua "ordem negra" apresentavam vínculos tão evidentes com essa tradição que só foram ignorados por motivos que nos escapam. Agora, vincular o nome de Hitler submetendo-o diretamente a tais influências sempre enfrentou maiores dificuldades, ou seja, era possível vincular a doutrina, mas não necessariamente o homem. Questão essa que, diga-se logo, parece-me um pseudo-problema: não seria necessário confirmar se Hitler teria ou não participado de alguma das diversas sociedades secretas de caráter ocultista da época para deduzirmos daí a presença de influências sobre o movimento que ele criou. Uma informação histórica como essa, capaz de iluminar sob um outro ângulo que não fosse aquele econômico-social jamais teria passado despercebido e muito

\footnotetext{
${ }^{86}$ Eliade, M. Mito e realidade, p. 51
} 
certamente já teria sido amplamente divulgada, certo? Infelizmente, nem todos os fatos históricos gozam do mesmo peso e do mesmo prestígio no mundo acadêmico.

Quando Hitler estava em Viena, estudando para ser pintor, em 1908, Lanz von Liebenfels já havia publicado mais de 25 números da revista Ostara e outros 40 números ainda seriam publicados antes que o jovem Adolf partisse de Viena em 1913. A primeira pessoa a decidir explorar as semelhanças entre as convicções políticoideológicas de Hitler (e conseqüentemente do nacional-socialismo) logo após o final da guerra não era nem filósofo e nem sociólogo (o que é bastante sugestivo), mas um psicólogo social chamado Wilfried Daim. Interessado pelo estudo das crenças sectárias e das ideologias políticas, Daim ficou muito impressionado com a semelhança, presumida por August M. Knoll, ainda em 1930 (frente a um auditório cheio de estudantes em Viena) entre as idéias nazistas e as publicações da revista Ostara. O objetivo de Knoll era ridicularizar o partido nazista. Já o de Daim, 21 anos depois, era escrever um livro apresentando o nazismo como um perverso sistema religioso. Imaginem o contentamento deste quando descobriu que Lanz von Liebenfels ainda estava vivo, morando em Viena-Grinzing...

Daim apressou-se e conseguiu uma entrevista com o lendário ariosofista em maio de 1951. Nessa entrevista Lanz lhe informa que Hitler o teria visitado na oficina da Ostara no ano de 1909, e parecia recordar de detalhes da conversa que tivera com o jovem Hitler. De acordo com seu relato, Hitler lhe dissera estar muito interessado em suas teorias raciais e que conseguia os números da Ostara em uma tabacaria próximo de onde vivia, em Felberstrasse. O motivo da visita era a intenção de conseguir os números atrasados da revista e completar sua coleção, e como Hitler lhe parecera um rapaz muito pobre, Lanz lhe ofereceu gratuitamente os números atrasados e algum dinheiro para que ele regressasse ao centro da cidade. Os dados eram mesmo importantes, mas o relato ainda precisava ser confirmado por evidências independentes. A primeira dessas evidências foram os registros da polícia que confirmavam que Hitler teria mesmo vivido entre 18 de novembro de 1908 e 20 de agosto de 1909 no número 22/16 da Felberstrasse, onde morava com o amigo August Kubizek. E de acordo com a câmara austríaca de tabaco, havia de fato uma tabacaria na Felberstrasse 18, possivelmente o lugar onde Hitler comprava os exemplares da revista, segundo o relato de Lanz. Quanto à pobreza de Hitler nessa época, confere com o fato de que em 1909, Hitler passava por um período de penúria que o obrigara a refugiar-se do frio em pousadas miseráveis, e para concluir, de acordo com Goodrick-Clarke, 
"se deve considerar que é pouco provável que Lanz tenha inventado uma associação com Hitler e a ideologia nazista em 1951: Viena estava sob ocupação dos aliados e as investigações políticas seguiam seu curso. Portanto, parece mais provável que Hitler tenha realmente visitado Lanz e que fora um leitor regular de Ostara" $^{\natural 7}$.

Pode ser, mas a conclusão de Goodrick-Clarke está longe de exibir o vigor de uma consequiência lógica. O narcisismo (ou a loucura) de Lanz, e mesmo a força de suas convicções poderiam muito bem ter neutralizado suas precauções frente à caça às bruxas do pós-guerra. Como indicamos antes, a coerência das idéias de Hitler e do nazismo com as convicções de Lanz e outros ocultistas da época têm a força de uma evidência capaz de tornar a discussão acerca do encontro entre Hitler e Lanz em um problema menor.

\footnotetext{
${ }^{87}$ Goodrick-Clarke, Las oscuras raices del nazismo p. 244-245.
} 


\section{CAPÍTULO VI: O MAPA DO LABIRINTO E A RUÍNA DA RAZÃO}

\author{
"O caráter sádico-perverso da ideologia da raça \\ revela-se também na atitude perante a religião. $\mathrm{O}$ \\ fascismo seria um retorno ao paganismo e um \\ arquiinimigo da religião. Muito pelo contrário, o \\ fascismo é a expressão máxima do misticismo \\ religioso."
}

(Wilhelm Reich)

\section{Do Romantismo ao Neopaganismo}

Na baixa Idade Média, com o desenvolvimento da burguesia, a afirmação das monarquias feudais e o cisma do Oriente, que rompe a unidade do cristianismo, a igreja começa a enfraquecer. Os reis, ao longo do século XIII, reagem ao internacionalismo pontifical e começam a rejeitar o poder do papa sobre os assuntos políticos e econômicos dos reinos. Em fins da Idade Média, ajudados pelos horrores da Santa Inquisição, as massas populares, por mais impregnadas de uma religiosidade que mesclava elementos pagãos com cristãos, começavam a fazer oposição à Igreja, enquanto as monarquias feudais conseguiam centralizar o poder real aliando seus interesses - de submeter a nobreza e a Igreja - aos de uma classe social emergente, mas muito poderosa, que desejava a formação de um mercado nacional: a burguesia. No século $\mathrm{XV}$, as monarquias que já haviam concretizado suas pretensões centralizadoras lançam-se, graças ao financiamento da burguesia, às grandes navegações. Temos aqui uma mudança radical em relação ao período anterior: a riqueza deixava de ser representada pela posse de terras e começava a ganhar mobilidade através da burguesia, o que fez com que a riqueza de um país passasse a ser medida por suas reservas de ouro e prata.

As mudanças decorrentes da saída da Idade Média também foram sentidas nas artes, na religião e nas ciências. Nas artes, principalmente, tivemos o que ficou conhecido por "Renascimento", uma ruptura com as idéias medievais, que buscou inspiração no mundo greco-romano, significando, de certa forma, a expressão do movimento humanista, que recolocava o homem no centro do mundo e que por sua vez devia-se ao absolutismo e ao crescimento da burguesia. Mas o Renascimento não se restringiu só às artes; o estudo do homem e da natureza também levou ao progresso das 
ciências. Na religião, a Igreja católica via seu poder enfraquecer-se progressivamente com o aumento das heresias e com a Reforma Protestante, um amplo movimento de revigoramento religioso nascido no seio da Igreja, e que Max Weber entende como o principal móvel do capitalismo, sobretudo sob a influência do calvinismo.

Ainda no século XVI, Calvino (1509-1564) dinamiza o movimento reformista iniciado por Lutero através da incorporação de novos princípios à matriz da doutrina luterana (livre interpretação da Bíblia, negação do culto aos santos e à Virgem Maria, contestação da autoridade papal, etc.), destruindo completamente a possibilidade do livre-arbítrio e pregando a predestinação absoluta do homem: alguns já nasceriam predestinados à salvação, enquanto que os demais (a maioria) estaria condenada à danação e à morte. Deus já escolhera assim, desde sempre, aqueles que queria levar à danação, através de um julgamento oculto e incompreensível. E por que seria assim? Porque assim queria Deus.

A radicalidade das proposições calvinistas gerava uma tensão psicológica terrível, a de saber quem seriam os escolhidos para a vida eterna. O homem não tinha como descobrir o que Deus havia lhe reservado, mas era possível deduzir uma resposta a partir de alguns indícios. Calvino afirmava que somente os predestinados seriam capazes de obter sucesso, e que todo trabalho, sendo realizado com honestidade, seria agradável a Deus. Isto terá duas conseqüências: a primeira delas é que as práticas econômicas até então condenadas pela Igreja convertiam-se agora em trabalho pela glória de Deus; a segunda, é que resolvia minimamente a tensão psicológica gerada pela predestinação absoluta, afinal, se o homem se empenhasse no trabalho e fosse bem sucedido na vida, ele teria uma confirmação de ter sido eleito para a vida eterna. A liberação do homem para o trabalho realizada pelo calvinismo e o estímulo capitalista gerado pela teoria da predestinação vinham bem ao encontro das idéias da burguesia.

A reação da Igreja não tardaria, através do que ficou conhecido como ContraReforma. Em 1545-1563, a Igreja católica manifesta-se através do Concílio de Trento, reafirmando os dogmas centrais da doutrina católica, como a manutenção do celibato, a hierarquia eclesiástica, o culto aos santos e à Virgem Maria, a importância dos sacramentos, a necessidade das obras para a salvação e, principalmente, a supremacia do papa e da Igreja como a única com poder para interpretar as escrituras. O braço armado da Igreja para impor seus dogmas era o já conhecido e eficaz tribunal do Santo Ofício (Inquisição). 
O humanismo e o Renascimento, que tiveram seu auge entre o final do século XV e meados do século XVI, podem ser considerados dois momentos de um único movimento, já que eles compartilhavam algumas características fundamentais, e dentre elas, a afirmação do valor da dignidade humana, e a indagação da natureza sem as amarras da religião. Mas o humanismo, diferente do que se possa imaginar, não era antireligioso, por mais que fizesse oposição ao pensamento medieval representado pela escolástica que, em linhas gerais, tentara harmonizar a fé com a razão. É da crise da escolástica que amadurece o humanismo.

Sobre a relação entre humanismo e religião, Sciacca aponta que

“com efeito, por um lado, sobretudo o Humanismo italiano, tende a acentuar a presença do divino no próprio homem. Por outro lado, o Humanismo europeu tende a centrar o elemento religião e transcendentístico sem ainda negar o homem em Deus. Do Humanismo com tendência antropocêntrica nasceram as correntes racionalistas, filosóficas e científicas, como as correntes imanentísticas e historicísticas que caracterizam o pensamento moderno. Do Humanismo com tendência super-teológica nasceram os movimentos religiosos, desde o movimento luterano" ${ }^{1}$.

Daí se depreende que a reforma protestante, antes de ter sido um verdadeiro e óbvio retrocesso no seio do humanismo e do renascimento, pode ser considerada como um momento deste movimento, ao anunciar a autonomia do homem religioso frente à autoridade da igreja, e da interpretação das escrituras. O humanismo desejava uma renovação religiosa capaz de revigorar a tradição católica e de dar mais liberdade à investigação da natureza. A reforma protestante, a princípio, parecia apta a realizar essas aspirações dos humanistas, mas imanente à doutrina luterana do "servo arbítrio", que supunha a salvação unicamente através da fé, em franco detrimento da salvação através das obras (como pregava a tradição católica), acaba por negar a autonomia do homem. A ruptura entre reforma e humanismo acaba por se tornar inevitável. Como pudemos notar, a ruptura no tempo entre passado e presente, com a conseqüente substituição de uma visão de mundo teocêntrica que durara dez séculos para uma visão antropocêntrica, dá-se no Renascimento, sofre um pequeno revés com os movimentos da Reforma e da Contra-Reforma, mas volta a ganhar fôlego no século XVII, e daí por diante nunca mais enfraquecerá.

\footnotetext{
${ }^{1}$ Sciacca, M. F. História da Filosofia, p. 8.
} 
Essa mudança, que apontaria para o recrudescimento daquele desencantamento operado pelo cristianismo, começaria a desencantar a própria religião cristã através da ciência nascente. Se for possível afirmar que o futuro novo que se revela continuaria permeado de superstições que a ciência jamais conseguiria erradicar completamente, e que esse novo tempo permaneceria religioso, não é menos verdade, nota Weber, que o homem de nosso tempo não é capaz de imaginar o quanto os tempos passados haviam sido mais religiosos. A separação entre Igreja e Estado e a precedência deste sobre aquela, bem como as visões de mundo fornecidas pela ciência emergente, concorrentes dos dogmas cristãos até então incontestáveis, marcaram uma profunda transformação na vida do homem pós-renascentista.

No século XVII, as explicações da natureza oferecidas pela religião não satisfaziam mais o homem moderno, que queria uma objetividade que o fizesse alcançar uma compreensão dos fenômenos e leis subjacentes à natureza, sendo necessário um método de exploração capaz de conduzir a razão às verdades que o mundo natural escondia. Todas as pré-concepções dogmáticas deveriam ser sustadas do pensamento, que passava a duvidar de qualquer conhecimento a não ser o "penso; logo, existo" cartesiano, cuja dúvida metódica obriga a razão a aceitar como verdadeiro somente aquilo que pudesse ser demonstrado. Era o fim das verdades de fé e o surgimento das verdades da razão. Foi este século que assistiu à afirmação das ciências experimentais, às explicações racionais do universo, ao progresso nas ciências físicas com Isaac Newton, Pascal (1623-1662) e Torricelli (1608-1647), na astronomia com Galileu Galilei (1564-1642) e Johann Kepler (1571-1630), na matemática com Fermat (16011630), Leibniz e Descartes. Todas essas descobertas substituíram a idéias de um universo imóvel pelo de um cosmos em constante movimento. E se tudo o que se encontrava na natureza estava em movimento, esse movimento significava progresso.

A estes progressos da ciência e da filosofia do século XVII, principalmente o racionalismo de Descartes e o empirismo de Locke, ligam-se as origens de um movimento intelectual de largas proporções que possuirá uma importância perene na vida do homem moderno: o iluminismo. Também conhecido como ilustração ou época das luzes, o iluminismo foi um movimento cuja maior expressão se deu na França, exatamente o país que era o palco mais expressivo das contradições do antigo regime, onde os limites feudais mais se chocavam com os interesses da burguesia e com o desenvolvimento do capitalismo. A burguesia, que antes financiava o absolutismo com o objetivo de ver seus interesses considerados, começa a sentir o próprio regime que ela 
ajudara a formar como um empecilho para o seu desenvolvimento. Tolhida por uma sociedade dividida em ordens ou Estados (clero, nobreza e povo), ela começava a sentir que seus interesses não eram os mesmos da nobreza, e que seu status social não era condizente com seu poder econômico. Os ideais racionalistas do século XVII, que apontavam para um universo em eterna mudança e progredindo sempre para melhor, enchia de otimismo a burguesia, que percebia a si mesma como o veículo do progresso frente ao conservadorismo do antigo regime. Ao mercantilismo ela opunha a idéia do "laissez-faire, laissez-passer", isto é, a idéia de uma economia capaz de ser regida por si própria sem a intervenção do Estado.

No nível político-ideológico, ela reafirmava a autonomia humana e a soberania do povo, criticando duramente a Igreja e o direito divino dos reis. Mas os iluministas não eram ateus, e sim deístas; Deus estava presente na natureza e também no homem, daí pregarem uma religião de tolerância, apoiada na razão e baseada na crença de um ser supremo. Já na política, por mais que condenassem o absolutismo, pensavam ser importante a existência de uma monarquia centralizada, cujo governante seria auxiliado por filósofos: era o despotismo esclarecido, uma política de reformas que foi executada por diversos soberanos europeus. E o iluminismo vem oferecer a justificativa que faltava para que a burguesia tomasse o poder de assalto através de uma verdadeira revolução burguesa. Dentre as revoluções burguesas, duas teriam especial importância no delineamento das fronteiras daquilo que denominamos "modernidade": a Revolução Industrial e a Revolução Francesa. O século XVII vê nascer um processo de transformação global que atinge todos os níveis da estrutura social (indústrias, bancos, agricultura, transportes, comércio, etc.) que marcam a emergência do sistema capitalista, e que teve, no nível econômico, a concretização, através da Revolução Industrial, um largo processo de mecanização das fábricas operado pela burguesia.

As condições da Revolução industrial amadureceram ao longo dos séculos XV ao XVIII, quando a burguesia acumulou capital através da concentração da produção e de enormes somas de dinheiro. No setor industrial, essa concentração se deu com a divisão do trabalho, em que os artesãos recebiam a matéria-prima mas não mais ficavam com o produto da sua labuta. Eles trabalhavam em troca de um salário porque não tinham mais como possuir seus instrumentos de trabalho (as máquinas): foi $o$ surgimento da indústria manufatureira. No setor mercantil, a acumulação se deu através da circulação de riquezas, ou seja, através do capital comercial, que é a diferença entre preço de compra e de venda das mercadorias, ou seja, através do lucro, acumulação essa 
que só foi possível graças à espoliação dos continentes asiático, americano e africano, submetidos aos danosos acordos comerciais entre colônia e metrópole, bem como ao tráfico de escravos. No setor agrícola deu-se o cercamento dos campos, momento em que a burguesia passa a controlar melhor os rendimentos provenientes da terra, substituindo os arrendamentos e o sistema de parceria. Sem ter como produzir o seu sustento através da terra, os camponeses viram-se obrigados a vender sua força de trabalho nas indústrias.

Assim, a acumulação de capital e o cercamento dos campos forneceram as condições necessárias para a Revolução Industrial e o desenvolvimento do capitalismo, por fazer surgir o binômio característico do novo sistema de produção: o capital e o trabalho (a mão-de-obra). Porém, o cercamento dos campos, mais do que liberar mãode-obra, fez surgir uma nova classe social - o proletariado - que em breve ditaria os rumos das tensões sociais. Daí por diante o antagonismo de classes dar-se-ia entre burguesia e proletariado e não mais entre nobreza e burguesia. Os camponeses que antes foram aliados da burguesia, formando uma força revolucionária em luta contra as forças de conservação do antigo regime, em breve dariam origem ao proletariado como força revolucionária enquanto a própria burguesia convertia-se em força de conservação. As forças de transformação, no momento representadas pela burguesia, ganharam impulso, no plano econômico-social, através da Revolução Industrial, e no ideológico, através do iluminismo. A burguesia agora, mais do que dinheiro, terras e indústrias, queria o poder.

Liderado pela burguesia e legitimado pelos ideais iluministas de igualdade e fraternidade, o povo (na verdade, uma massa de desempregados), insatisfeito com as transformações sociais do século XVIII (aumento populacional, que agravara as contradições do antigo regime e gerara a necessidade de aumento da produção de alimentos), incluindo o alto custo de vida e a reação aristocrática que, para enfrentar a alta de preços, resolveu aumentar sua renda cobrando mais e mais impostos, toma a Bastilha, símbolo da opressão do antigo regime e executa o rei, a rainha e uma centena de nobres. Daí por diante, os burgueses partiriam para a conquista do mundo.

Pois bem, a Era Clássica cobre todo esse período. Inspirada pelo Humanismo, pelo Renascimento e em seguida pelas Revoluções Francesa e Industrial, a arte e a literatura desse período são fruto da reação ao teocentrismo, ao misticismo e ao ascetismo do período medieval. Por isso o classicismo preza o equilíbrio e a harmonia, tanto quanto a clareza, como um reflexo do primado da razão. Valores como o Belo, o Bem e a Perfeição, alçados à categoria de universais, conduzem os artistas do 
classicismo ao culto da antiguidade greco-latina. Essa idealização da antiguidade surge em oposição à desvalorização do período imediatamente anterior, representado pela arte medieval. Os clássicos, imitando os antigos, entendem o Belo como racional e verdadeiro, e o verdadeiro como natural.

Mas, diferente do que se imagina, o período clássico, mesmo funcionando sob o primado da razão, não esteve livre de inflexões causadas pelo clima religioso da Europa que via, no final do século XVI e ao longo de todo o século XVII, soprarem os ventos da Contra-Reforma. Por conta disso, nos países onde os conflitos religiosos oriundos da crise religiosa foram mais intensos, veremos surgir uma modalidade um tanto "deformada" de classicismo que ficou conhecida como Barroco. Houve, portanto, um Barroco ibero-jesuítico em Portugal, Espanha, Itália e na América Latina, e um Barroco luterano-reformista na Alemanha, Holanda e Inglaterra. Onde as crises religiosas foram tênues o Barroco praticamente não existiu.

A tensão religiosa gerou, no interior do classicismo, uma dualidade, originada pelos desdobramentos do Humanismo e do Renascimento por um lado, e pela pressão da Igreja Católica e do protestantismo, por outro, que postulavam um regresso ao teocentrismo medieval. Notamos aqui, portanto, um saudosismo que reencontraremos mais tarde no pré-romantismo: a saudade do homem do Barroco pela religiosidade medieval contrastava com a valorização do dinheiro e dos valores mundanos. Essas angústias e incertezas do homem da época barroca refletir-se-ão na produção artística do período sob a forma de antíteses e paradoxos e, sobretudo, através de um rebuscamento exagerado da linguagem. Tais jogos de linguagem, que de certa forma expressavam o virtuosismo do artista, violando o ideal de clareza e simplicidade do classicismo, cumpriam a função de burlar a censura inquisitorial.

No século XVIII, superados os conflitos espirituais do século XVII, com a fé e a religião sendo substituídas pela razão e pela ciência, o equilíbrio clássico, abalado pelo interlúdio do Barroco, é restabelecido, no século XVIII, através do Neoclassicismo, também conhecido como Arcadismo. O século XVIII, o Século das Luzes, impulsiona o retorno para os valores do Classicismo: arte equilibrada, voltada para o belo e a perfeição, bem como para a imitação da natureza. O tema, bastante caro ao Arcadismo, é o fugere urben, que expressa já a fuga da cidade ou da civilização, em um tempo em que a industrialização e o crescimento das cidades caminhavam a pleno vapor. Daí o bucolismo característico do movimento, onde vemos ressoar, também, a poesia bucólica de Teócrito e Virgílio. 
Mas convém notar, porém, que segundo os críticos do Arcadismo, ele tem sabor de "café coado pela terceira vez". Tal crítica deve-se à despreocupação dos neoclássicos com a originalidade. Sua preocupação jaz na imitação, na cópia perfeita do modelo. Entretanto, nem todos os integrantes da Escola Neoclássica ficaram rigidamente presos ao artificialismo poético do período que obrigava a sensibilidade a adequar-se aos estreitos limites do racionalismo, expressando-se através das imagens clássicas e mitológicas da antiguidade. Tais artistas começam a impor sobre o quadro de referências do neoclassicismo sua própria subjetividade, o que irá conferir às suas obras uma originalidade ausente neste. Essa tendência, mais emotiva, apesar de ainda presa ao antigo modelo, irá prefigurar um momento de transição para o Romantismo que ficou conhecido como pré-romantismo.

Antes mesmo de definirmos o Romantismo, convém destacarmos que existem duas histórias distintas envolvidas nessa tentativa de definição: a do romantismo como movimento cultural e a história da expressão "romântico". Existe na concepção popular uma definição razoavelmente precisa da expressão, associada sobretudo ao "amor romântico". Neste sentido, "romântico" é sinônimo de "apaixonado", de "sonhador" e de "ingênuo". O romântico seria, portanto, o sentimental, afeito a ilusões amorosas. De certa forma, a concepção popular guardou algo do conceito de romantismo que nos foi legado pelo século XIX, sobretudo se considerarmos que a associação do termo "romantismo" ou "romântico", com o amor, dá a este uma configuração mais “espiritual” do que sensual.

Um pouco menos preciso é o uso do termo no sentido literário pela concepção popular. Neste caso, o termo "romance" aplica-se a qualquer obra literária escrita em prosa acerca de personagens fictícios. E graças à popularização de obras de valor estético mais que duvidoso, destinadas sobretudo a leitores os menos exigentes, o termo passou a definir hoje em dia aquela literatura lacrimosa e por vezes erótica especializada em narrar histórias amorosas com um sensacionalismo sentimental cujo único objetivo é divertir e fazer chorar. Mas até nisso, se lembrarmos do Werther de Goethe, que em sua época gerou o mesmo efeito histérico, podemos ver os ecos do movimento romântico.

Porém, em sua origem, o termo "romantismo" referia-se a algo bastante diferente. $\mathrm{O}$ termo surge, inicialmente, como advérbio sob a forma latina romanice, que significava "à maneira dos romanos". Em francês o termo romanice deu origem a romanz, depois romant e logo em seguida roman. No século XII, então, o termo designava qualquer narrativa em língua popular (que não estivesse, portanto, escrita em 
latim). Por volta do século XIV ocorre uma especialização na acepção do termo, que passa a ser utilizado para definir os romances de aventura escritos em verso. No século $\mathrm{XV}$ as narrativas de cavalaria, escritas em prosa, passaram também a utilizar o termo ${ }^{2}$.

A partir do século XVII deduz-se, no francês, do advérbio roman o adjetivo romantique, no sentido de "romanesco". O termo, traduzido para o inglês, converteu-se em romantic, cuja evolução semântica dará origem a romantismo. Um momento importante na história do termo foi sua aplicação ao sentimento despertado pela contemplação da natureza (paisagens solitárias, selvagens, montanhosas), até que em Rousseau, em 1777, o termo se consagra como "a generalização de um sentimento de fuga à realidade social, de busca de um refúgio solitário, em colóquio com a natureza, capaz de nos conduzir às fontes puras que nos haviam gerado em nossa autenticidade primitiva",3.

Quanto à origem do termo "romântico", ele parece remontar ao final do século XVIII, possuindo sentidos diversos. Elas denominavam as línguas de origem romana (como é o caso do francês, espanhol, português, italiano e romeno) tanto quanto a literatura produzida nessas línguas, em medidas rítmicas não-clássicas e que tinham “para o público alemão da época traços fantásticos, estranhos e maravilhosos, isto é, românticos" $"$.

Conta-se, porém, que a associação do termo "romantismo" a um movimento filosófico-literário deve-se a Friedrich Schlegel, no final do século XIX, personagem muito conhecido do romantismo alemão. A oposição do termo a "clássico" devemos a Mme. Staël quando da tradução de romantisch. E é exatamente a partir dessa oposição que o movimento romântico é definido. A época filosófico-literária definida como romantismo compreende, muito grosseiramente, o intervalo entre 1790 e 1830. Sua reação é ao classicismo ou Era Clássica, representada por Dante, Camões, Shakespeare, Cervantes, Michelangelo, Leonardo da Vinci, etc., e que compreende o Renascimento, o Barroco e o Neoclassicismo/Arcadismo.

Esse novo período representa e exprime a nova sensibilidade das classes médias urbanas, representadas pela burguesia emergente. Mas não é só isso: o romantismo representa também uma reação, uma crítica ao modo de vida no interior da sociedade

\footnotetext{
${ }^{2}$ Elia, S. Romantismo e linguística, in: Guinsburg, J., O romantismo,. p. 114.

${ }^{3}$ Idem, ibidem, p. 115.

${ }^{4}$ Brüseke, F. J. Romantismo, mística e escatologia política, p. 24.
} 
capitalista, que teve origem com o surgimento da burguesia e com a Revolução Industrial. Em resumo,

"Enquanto movimento histórico, o Romantismo surgiu na Alemanha e na Inglaterra, entre a segunda metade do século XVIII e a primeira metade do século XIX, em defesa da liberdade de sentir, de viver e de expressar, apregoando a derrocada do qualquer forma de absolutismo: político, contra o imperialismo e a favor de regimes constitucionais; religioso, contra o dogmatismo e a favor de uma religião mais sentida e mais natural; social, contra a prepotência das classes dominantes e a favor das aspirações da nascente classe burguesa; estético, contra as regras do classicismo e a favor de uma total liberdade de expressão artística"5.

Entretanto, se é verdade que a ascensão da burguesia cria um novo mercado consumidor de literatura, menos exigente se comparado com os nobres que consumiam a arte aristocrática do classicismo, nem tudo no romantismo é mero entretenimento. Otto Maria Carpeaux nos lembra que o romantismo é um movimento poético (Shelley, Novalis, Hugo, Coteridge, etc.), enquanto sugere que, em comparação com esses grandes poetas, a literatura de ficção romântica seria surpreendentemente fraca, mesmo tendo sido muito lida na época.

“pois é um público novo que lê esses romances e novelas. Não são mais os diletantes aristocráticos do século XVIII. É o novo público burguês que surgiu com a abolição do Ancien Régime pela Revolução Francesa, um público menos exigente que não se preocupa com teorias literárias" ${ }^{\text {. }}$

Carpeaux, pelo menos neste trabalho, nos deixa a impressão de que existem dois tipos de leitores da produção literária do período romântico: os mais exigentes (cultos) e os menos exigentes. Ambos representantes da burguesia, somos levados a presumir. Os primeiros consumiriam "a grande massa da literatura de ficção da época romântica" - os romances históricos (sobretudo medievais), cujo principal representante seria Walter Scott. Mas os leitores de Notre-Dame de Paris (1831), de Victor Hugo, obra "capaz de entusiasmar os leitores menos exigentes" também não são poupados. Os mais exigentes apostavam em E. T. A. Hoffmann, Poe e Gogol.

\footnotetext{
${ }^{5}$ D'Onofrio, S. Literatura ocidental: autores e obras fundamentais, p. 327.

${ }^{6}$ Carpeaux, O. M. Prosa e ficção no Romantismo, in: Guinsburg, J., O Romantismo, p. 161.
} 
Entretanto, apesar de vinculado à burguesia, o romantismo representou uma reação aos ideais de racionalidade expressados pelo Iluminismo. A contradição parece evidente: se o romantismo é fruto tanto do iluminismo quanto da revolução industrial, como ele poderia representar ao mesmo tempo os anseios da classe média burguesa e uma mística da moderna sociedade industrial?

Ao que parece, alguns burgueses eram mais sensíveis que a maioria de seus companheiros de classe e rapidamente perceberam que certos valores humanos foram esquecidos no caminho trilhado pela razão, o que os conduziu a uma crítica da sociedade moderna. Mas essa nova forma de sensibilidade, de certa maneira, já estava presente no iluminismo, sobretudo em Rousseau. E a manifestação mais imediata disso surgira no neoclassicismo através de alguns de seus motivos clássicos: o Carpe Diem, o Locus Amoenus e o Fugere Urbem. A idéia era a de buscar no campo a beleza e a simplicidade ausentes na cidade. D’Onofrio resume bem as contradições românticas:

\footnotetext{
"A utopia liberalista da segunda metade do século XVIII entra em conflito com a dura realidade histórica, marcada por guerras políticas, religiosas e de classes sociais. Daí os estudiosos do complexo fenômeno do Romantismo europeu distinguirem duas linhas de forças antitéticas: de um lado a corrente quietista ou reacionário, que se alimentava de sonhos e de ilusões, idealizando o real e a natureza (o mito do bom selvagem, o romance de amor e de aventura, a lírica melancólica dos Lake's Poets, a ópera melodramática); de outro lado, uma corrente revolucionária, que queria sacudir o modelo burguês de vida, insurgindo-se contra qualquer tipo de constrição de ordem social ou moral: a corrupção do herói titânico ou prometáico que desafia a autoridade constituída e questiona os valores éticos e religiosos, dedicando-se a amores licensiosos, ao álcool, ao ópio, a viagens em regiões exóticas. Praticando até o suicídio ( o "mal do século"), como forma de fuga da realidade castradora de suas aspirações"7.
}

A aparente contradição a que aludimos só toma forma porque consideramos o iluminismo como um movimento coeso, sem fissuras e contradições, o que não é verdade. Fruto tanto da ciência experimental quanto do racionalismo cartesiano, o iluminismo coloca a natureza contra a história, afirmando ser esta a degeneração daquela:

"Estado de natureza é o oposto do desenvolvimento histórico; natureza e história se enfrentam e se cotejam, a história é a degeneração da natureza, o reino das

\footnotetext{
${ }^{7}$ D’Onofrio, S. Literatura ocidental: autores e obras fundamentais, p. 328.
} 
astúcias dos poderosos e dos ricos, que conjuravam e conjuram em prejuízo dos ingênuos, a grande maioria, à qual somente a natureza pode dar uma nova ordem de bem-estar, progresso e felicidade. Mais que de retorno ao estado primitivo, se trata de desenterrar a espontaneidade e a clareza da natureza do peso das superestruturas históricas",

Ou seja, ao mesmo tempo em que o iluminismo acredita no progresso e confia na civilização, é forte a sua sedução pelo estado de natureza, expressão de uma suposta inocência primitiva. No lugar do sobrenatural, através da crítica da religião, o iluminismo opõe o natural, o que nos conduz a Rousseau (1712-1778), principal filósofo iluminista do século XVIII. Mas algum pessimismo já pode ser encontrado em Voltaire (1694-1778), o maior representante da religião das Luzes. Para tanto, basta lembrarmos da crítica mordaz ao otimismo metafísico de Leibniz presente em Cândido. Sobretudo sob o impacto ainda recente do terrível terremoto que destruiu boa parte de Lisboa em 1755, e da realidade de miséria e sofrimento da civilização secularizada, Voltaire não estava mais disposto a subscrever qualquer tipo de otimismo ingênuo.

Devemos notar também que ao longo dos séculos XVII e XVIII, a questão que ocupava os pensadores era o combate ao absolutismo monárquico. Ora, se o absolutismo representava a opressão política sobre a natureza humana, nada mais natural que a crítica tomasse o partido da natureza. Por isso, no pensamento de Locke (1632-1704), precursor do iluminismo, notamos sua oposição à argumentação absolutista de Hobbes (1588-1679). Para Locke, o estado de natureza não era a "guerra de todos contra todos", característica de uma orientação pré-política e pré-social. Para o teórico da revolução inglesa, o estado de natureza representa apenas um estado prépolítico, onde os homens viviam uma vida sem lutas e anarquias, governada pela razão. Daí sua idéia de uma "lei natural", adaptada à razão humana e capaz de resguardar os direitos inalienáveis dos homens - liberdade, vida e propriedade. Ao governo, cabia proteger esses direitos.

A confiança dos iluministas na ciência e na razão obriga-os a recuar diante de todos os problemas onde a aplicação da razão não fosse digna de confiança. A natureza surge então como o objeto mais apropriado para a investigação científica, o que não acontece com a história. Voltaire, por exemplo, subscreve a concepção de Pascal (1623-

\footnotetext{
${ }^{8}$ Sciacca, M. F. História da Filosofia. Vol. II, p. 152.
} 
1662) de que a história seria fruto do acaso, e por conta disso seria inválida para a razão.

Entretanto, como pudemos notar, apesar da confiança dos iluministas na ciência e na razão, nem todos eram ingenuamente otimistas. Os enciclopedistas D'Alembert e Diderot, por conta mesmo de sua origem burguesa que mal disfarçava o rancor pelas classes privilegiadas, esboçavam um otimismo no progresso e no saneamento social a partir da difusão das luzes que não estavam presentes na fineza da formação aristocrática de Voltaire ou Montesquieu?

Rousseau também era sensível ao fato de que a humanidade havia melhorado pouco, mesmo com o progresso da ciência. E curiosamente, sua estréia como escritor expressa esse pessimismo. Em 1750, em Paris, quando teve notícia de que a academia de Digion, querendo saber "se o renascimento das ciências e das artes tinha contribuído para a corrupção ou para a purificação dos costumes", estava realizando um concurso sobre o tema, ele se candidata e vence o concurso. A premiação de seu trabalho, que afirmava que as ciências e as artes, bem como o progresso da civilização, seriam as principais causas dos males que afligiam a sociedade, é para dizer o mínimo, curiosa, se tivermos em mente que seu Discours sur les sciences et les arts estava sendo apresentado na França e no apogeu do Iluminismo.

É dele, como sabemos, a idéia do "bom selvagem", crença de que o homem, naturalmente bom, foi corrompido pela civilização. O que não significa uma tentativa ingênua de retornar à natureza. Rousseau está bem ciente dessa impossibilidade, portanto, não se trata de um retorno a um estado primitivo da humanidade, mas de uma tentativa de libertar a cultura de tudo o que nela existe de mecânico e rígido e por isso capaz de inibir a verdadeira natureza humana: inocente, boa e pacífica.

Para Gerd Bornheim, Rousseau representa, junto com Haman e Herder, uma reação ao século das Luzes e detêm-se sobre o seu subjetivismo, comparando-o com a de Descartes:

"Em Descartes, como na filosofia que dele derivou, a interioridade esgota-se em uma dimensão racionalista, expressa no Cogito, e os filósofos fazem a análise da razão, estudam a razão e o conhecimento racional. A interioridade de Rousseau é bem outra,

\footnotetext{
${ }^{9}$ Sciacca, M. F. História da Filosofia. Vol. II, p. 162.
} 
pois para ele interioridade é sinônimo de sentimento, e este é considerado superior à razão" ${ }^{, 10}$.

Rousseau iguala o "sentimento interior" capaz de superar a razão com a natureza, mas não aquela natureza no sentido cartesiano quando diz em Émile: "deixei, pois, de lado a razão, e consultei a natureza, isto é, o sentimento interior que dirige a minha crença, independentemente da razão"11. A concepção um tanto mística de natureza como algo interior, capaz de confundir-se com o espírito, tanto quanto seu apelo ao sentimento, são concepções francamente anti-iluministas e já apontam para uma superação do iluminismo no sentido do romantismo.

Anatol Rosenfeld, por sua vez, lembra-nos que nas origens do romantismo pesa o surto de pietismo, que na Alemanha se colocou contra a orientação protestante oficial, profundamente racional. O movimento, de caráter místico e nascido no seio do luteranismo, recusava os padrões objetivos da religião pela vivência religiosa íntima e fervorosa. Neste contexto de misticismo, o acento da religiosidade deslocava-se de fora para dentro em busca da iluminação capaz de revelar-lhe a graça divina. Tal atitude contemplativa, observa Rosenfeld, psicologiza a prática religiosa e a própria religião ${ }^{12}$. O movimento pietista era liderado por P. J. Spener (1635-1705) e A. H. Francke (16631705), derivando seu nome de um dos escritos de Spener, os Pia Desiderati (1675), onde a ortodoxia luterana é criticada em nome da "piedade cristã".

Essa hegemonia da subjetividade no romantismo surge como uma inversão epistemológica em relação à época clássica, quando o individualismo racionalista do iluminismo é substituído por um individualismo egocêntrico. Inversão essa que acabou por vincular o idealismo da visão romântica "à capacidade expansiva e à força irradiante do Eu", que assim configurado - como ponto central da realidade e passagem para o universo - assegurou um primado ontológico à vida interior ${ }^{13} . \mathrm{E}$ tal individualismo, de certa forma, culminará na idéia de "gênio", também característica do romantismo: "A medida do individualismo egocêntrico e organicista da visão romântica pode ser aquilatada pela idéia de gênio, que ocupou o centro da constelação das idéias na época do romantismo" ${ }^{\prime 14}$.

\footnotetext{
${ }^{10}$ Bornheim, G. Filosofia do Romantismo, in: Guinsburg, J. O Romantismo, p. 80.

${ }^{11}$ Citado por Bornheim, G. Filosofia do Romantismo, in: Guinsburg, J. O Romantismo, p. 80.

${ }^{12}$ Rosenfeld, A. Romantismo e Classicismo, in: Guinsburg, J. O Romantismo, p. 266.

${ }^{13}$ Nunes, B. A visão romântica, in: Guinsburg, J. O Romantismo, p. 58.

${ }^{14}$ Idem, ibidem, p. 60 .
} 
O culto ao "gênio original" no âmbito da criação artística também expressa uma oposição ao classicismo. Não se trata agora de virtuosismo técnico, de habilidade na composição das obras de arte na direção de uma perfeição artística guiada por um modelo consagrado. O que temos agora é uma explosão da originalidade contra as regras tradicionais, criação espontânea do artista que reflete não mais a perfeição objetiva, técnica da obra, mas a genialidade de seu autor, o que faz com que o critério de apreciação da obra não seja mais estético.

\begin{abstract}
"Agora, trata-se de um verdadeiro demiurgo, de uma força cósmica, inata, independente da cultura, que decifra de maneira intuitiva e direta o 'livro da natureza', criando titanicamente sob o impacto da inspiração. A sua criação é fruto da pura espontaneidade. Não pode nem deve ser retocada, torneada e acabada, por critérios artesanais de perfectibilidade. Ela surge toda e inteira, na completude da expressão autêntica, sincera. Assim, o valor da obra passa a residir em algo que não está nela objetiva e formalmente, e sim subjetivamente no seu autor - a sinceridade. Em outras palavras, o elemento da avaliação estética não é estético" ${ }^{\text {"15 }}$.
\end{abstract}

E a idéia de "gênio" não se refere apenas ao artista, ou a um sujeito. O caráter de um povo também pode ser considerado como um reflexo do seu gênio nacional. $\mathrm{O}$ legislador, o filósofo ou o homem de estado capaz de modificar o destino coletivo; o homem de ação ou o profeta religioso são todos encarnações do gênio individual ${ }^{16}$. Sobre essas bases já se assentava o Sturm und Drang (tempestade e ímpeto), movimento inspirado no título de uma peça de Frederico Maximiliano Klinger (publicada em 1776) e que encarnará o espírito do pré-romantismo alemão. Inspirado sobretudo em Rousseau, o Sturm und Drang preocupava-se com as injustiças sociais que vicejavam na Alemanha da época, tomando colorações por vezes revolucionárias.

Aos motivos do pessimismo rousseauniano juntaram-se o historicismo de um aluno de Kant que muito irá influenciar o desenvolvimento do movimento romântico, sobretudo a partir de sua amizade com Goethe: Johann Gottfried Herder (1744-1803). Foi com Herder que os românticos aprenderam a valorizar, em sua literatura, as tradições de sua nação, inspirado pela idéia central na filosofia da história de Herder, de que o homem, tendo sua origem no interior de uma determinada raça, sua formação subseqüente será influenciada por essa origem, o que inclui peculiaridades nacionais

\footnotetext{
${ }^{15}$ Rosenfeld, A. Romantismo e Classicismo, in: Guinsburg, J. O Romantismo, p. 267. Grifo nosso.

${ }^{16}$ Nunes, B. A visão romântica, in: Guinsburg, J. O Romantismo, p. 62.
} 
específicas. Daí a necessidade de estudarmos os costumes das civilizações do passado, mas sem o vício de julgarmos os seus valores a partir dos valores de nossa própria cultura. Com Herder vemos o despertar da valorização da consciência nacional, tema que influenciará rapidamente o movimento de jovens poetas do Sturm und Drang, que podem ser considerados, por sua vez, os precursores do nacionalismo e do romantismo alemão sob o conceito de Volk, em oposição ao cosmopolitismo do século XVIII.

"O nacionalismo alemão adotaria o conceito de Volk, a comunidade popular, para expressar um ideal político por uma mística do irracional. O movimento do Sturm und Drang será o precursor desse nacionalismo que busca as raízes originais do Volk e que posteriormente as encontrará não somente na pré-história mas fundamentalmente na biologia. Esse nacionalismo terá em Herder o seu precursor, devido em grande parte à influência da concepção rousseauniana sobre a importância das etapas primitivas e précivilizadas da evolução humana"17.

Nesse contexto, os temas mitológicos não tardarão a entrar em cena. O fascínio dos românticos pelo passado não se restringia à idealização da Idade Média; seu interesse recuava até o "primitivo", na intenção de encontrar ali o "bom selvagem" a que aludia Rousseau.

Esse interesse histórico-arqueológico pelo "primevo", pelo "original”, liga-se a seu sonho de reintegração numa nova unidade sintética que acarreta uma valorização do mito, tema capaz de agregar o turbilhão emocional, contraditório e imaginativo do movimento romântico. O mito converte-se para eles no elemento fundamental de sua visão, capaz de lhes dar acesso ao "uno", em oposição a um mundo cheio de fissuras e complicações alienantes, fruto de uma civilização racionalizada e que tudo dissocia ${ }^{18}$.

Essa tentativa de buscar as origens do ser humano no passado mais remoto tinha por hábito tomar as narrativas mitológicas como realidade histórica, sobretudo nas consciências mais místicas. O interesse pelo passado, sobretudo na Alemanha, acarreta o estudo da mitologia nórdica em oposição ao interesse na mitologia greco-romana. É nessa época que cresce o interesse pelos Edda e pela saga dos nibelungos - o Nibelungen -, tema que encontrará sua expressão maior na obra de Richard Wagner. Temas que no futuro serão articulados pelo movimento nacional-socialista sob o argumento de que a Alemanha renovada precisava ter sua própria religião, mais de

\footnotetext{
${ }^{17}$ Falbel, N. Fundamentos históricos do romantismo, in: Guinsburg, J. O Romantismo, p. 43.

${ }^{18}$ Rosenfeld, A; Guinsburg, J. Um encerramento, in: Guinsburg, J. O Romantismo, p. 282.
} 
acordo com seu caráter nacional. Mas como apontará Richard Grunberger, historiador do nazismo:

“ 'Religião' é, na verdade, uma palavra imprópria porquanto implica algo de ordem mais alta do que a mixórdia de adoração de ancestrais teutônicos e o culto da natureza que atendia às necessidades espirituais da elite nazista. A característica mais pronunciada deste Novo Paganismo era a rejeição de quase todos os aspectos do cristianismo, das virtudes de castidade e humildade ao simbolismo da cruz. O mistério da ressurreição cedia lugar à eterna renovação da raça, o caráter sobrenatural ao mito do herói, e o Natal cristão (antecipada sua data para coincidir com o solstício do inverno) ao Natal pagão" ${ }^{, 19}$.

Paralelamente a esse interesse no passado nacional germânico, encontramos uma valorização da Idade Média, também em sua dimensão mitológica, como atestam o interesse na lenda do Graal e em personagens mitológicos como Parsifal e o rei Arthur.

Mas não podemos deixar de considerar o seguinte: mesmo que o romantismo e o ocultismo representem uma reação ao mundo moderno, e que dessa luta tenha emergido uma revalorização do passado nacional alemão, com a substituição da mitologia grecolatina pela mitologia nórdica, não podemos igualar esses dois movimentos. Nos dois casos há um encantamento com tudo o que é natural e primitivo, bem como uma desconfiança quanto à ciência, elementos que somados conduziam facilmente ao misticismo, mas há no romantismo uma preocupação política, libertária, que pensamos estar ausente no ocultismo alemão do século XIX, apesar das influências que este sofreu a partir do romantismo. No momento, o que nos basta saber é que ambos os movimentos eram formas de reação ao mundo moderno, que o romantismo contava com elementos de misticismo, vindo a influenciar o misticismo moderno do século XIX, que o nacionalismo, por motivos históricos, estava presente em ambos, mas nem por isso esses dois movimentos seriam irmãos de sangue.

E foi exatamente o nacionalismo que conferiu ao misticismo alemão sua coloração mais peculiar e perigosa. Como vimos, Herder despertou nos alemães, a partir da idéia de que o homem se origina no interior de uma raça, a valorização da consciência nacional que influenciará o movimento do Sturm und Drang, precursor do romantismo e do nacionalismo. Essa valorização do passado nacional e da idade média alemã refletia a frustração quanto à unidade política, sempre lenta e difícil, substituída

\footnotetext{
${ }^{19}$ Grunberger, Richard. A história da SS, p. 41.
} 
pela unidade da cultura expressada no folclore e nos costumes, daí o interesse pela mitologia nórdica.

Sobre isso, Hannah Arendt argumenta que o pensamento racial alemão resultou do esforço de unir o povo contra a dominação estrangeira, tendo acompanhado as longas e frustrada tentativas de unificação fazendo com que fosse difícil distinguir os sentimentos nacionais do racismo declarado. Esse caráter peculiar conferido ao nacionalismo destinava-se a erguer um muro em torno do povo como substituto das fronteiras que não podiam ser claramente estabelecidas pela geografia ou pela história. Sendo assim, as idéias de "parentesco de sangue", de unidade tribal e de origem pura refletem o fracaso das esperanças de despertar no povo alemão sentimentos nacionais por outras vias culturais como o idioma ou a história. ${ }^{20}$

\section{Os mitos de origem}

Paradoxalmente para alguns, Nietzsche discute, em "Para além do bem e do mal", a falta de profundidade do povo alemão: a "alma alemã", ele comenta, "é múltipla, de origem vária, mais composta de elementos justapostos e sobrepostos do que propriamente estruturada" 21 . Com isso ele pretendia apontar que o alemão era um povo fruto "da mais monstruosa mistura e amálgama de raças", e ainda com mais ousadia ele supõe existir no alemão uma preponderância de elementos pré-arianos que o tornaria assim um "povo do meio", contraditório, incompreensível e mais terríveis (por conta desse desconhecimento) para si próprios do que os outros povos. Os alemães, esse povo que escapa a qualquer definiçãa (e por isso talvez o desespero dos franceses), exibiriam uma característica que lhes seria absolutamente peculiar: o fato de neles nunca morrer a pergunta “Que é ser alemão?”. Esse velho problema dos alemães que Nietzsche estava ridicularizando pode soar hoje quase como uma profecia ou uma intuição do abismo para onde essa obsessão com as origens poderia conduzir o povo alemão. Contudo, não se tratava de uma profecia, mas de uma análise precisa do passado.

Os alemães, aponta Poliakov, definiram sua identidade germânica primeiramente tomando consciência da identidade lingüística (em oposição à cultura latina) e somente depois é que essa busca de identidade irá apontar para a idéia de uma ascendência

\footnotetext{
${ }^{20}$ Arendt, Hannah. Origens do Totalitarismo, p. 195-197.

${ }^{21}$ Nietzsche, F. Para além do bem e do mal, p. 164.
} 
comum, ou seja, a comunidade da língua precedeu a comunidade da raça. E foi a partir do século XI que surgiu uma tradição pregando que os bávaros seriam originários da Armênia (do lugar em que Noé saiu da arca) e no século seguinte, em 1179, surge na tradição mística a idéia de que Adão e Eva - pasmem - falavam alemão. A explicação fornecida por uma adepta da mística renana Hildegard von Bingen era tão simples quanto curiosa: diferente das línguas dos dominadores romanos, que eram bastante diversificadas, o alemão era uma língua única, diferente de todas as outras, sendo assim, nada mais natural que o alemão fosse a língua original do gênero humano. Diferentemente dos franceses e dos ingleses, que conheciam as influências sofridas pelo seu idioma, os alemães, por conta mesmo da ignorância dos antepassados de sua língua, defendiam a originalidade do alemão, dando início à crença na pureza de sua língua. Nessa mesma época, final do século XV e começo do século XVI, um autor anônimo, como a adepta de von Bingen, escreve o "Livro dos cem capítulos", desenvolvendo a idéia da hegemonia germânica em um "Reich milenar" e argumentava que Adão era alemão $^{22}$.

Quando a obra "Germânia”, do historiador romano Caio Cornélio Tácito (55-120 d.C.), que narrava com precisão a história da Germânia e de seus povos foi redescoberta no século XV, ganhou força a idéia de que os germanos seriam autóctones, logo, que sua raça seria pura:

\footnotetext{
“creio que os germanos são naturais da própria terra e que jamais se mesclaram com a vinda e hospedagem de outros povos; pois, antigamente, todos que emigravam não iam por terra senão por mar e são raros os navios que de nosso mundo se aventuram a penetrar no Oceano imenso e, por assim dizer, oposto ao nosso",23.
}

Acreditava-se também, não bastando as explicações genealógicas que ligavam o passado dos alemães a Noé e a Adão, que o hebraico seria uma derivação do idioma universal, da língua mãe germânica, hipótese que receberia a aprovação de Leibniz, que julgava mesmo que o alemão aproximava-se muito mais dessa língua-raiz original que o hebraico. Mas a superioridade do alemão, calcada na autoctoneidade, na língua ou na genealogia que ligava os germanos a Adão não resistiria ao século das luzes, quando a teologia racionalista passa a contestar o mito bíblico. Contudo, a crítica à mitologia judaico-cristã não abandonou toda explicação mitológica; ela viu florescer, nessa

\footnotetext{
${ }^{22}$ Poliakov, L. O mito ariano, p. 65-73.

${ }^{23}$ Tácito, C. C. Germânia.
} 
mesma época, tentativas de reabilitar os antigos deuses germânicos, sobretudo na figura do poeta Klopstok. Após sua conversão em 1766-1788 à mitologia germânica quando esteve na Dinamarca, Friedrich Gottlob Klopstok exorcizou toda a mitologia grega substituindo Júpiter por Wotan, Afrodite por Freya e as parcas pelas Nornas, convertendo-se no primeiro autor alemão a propor uma nova visão de mundo calcada nessa nova mitologia de deuses germânicos sanguinários. Com Herder, mitólogo mais influente que Klopstok, o argumento foi retomado. Convém lembrar que nessa época a Alemanha havia caído sob o domínio da França de Napoleão e salvo raras exceções como Hegel, que via em Napoleão a encarnação do espírito universal - a maioria dos pensadores, como "os jovens românticos, conscientes de seu gênio, começam a celebrar a missão universal alemã, uma 'eleição' que implica evidentemente o sentimento de uma comunidade de origem, mas que de início quer ser profundamente pacífica” ${ }^{\text {,24 }}$ E entre eles, Schiller, que acreditava que o povo alemão era o núcleo do gênero humano, responsável pela educação humana, e que supunha também que no futuro a língua alemã reinaria sobre o universo.

Mas o exemplo de Fichte supera em muito as apologias da cultura germânica presentes tanto em Schiller quanto em Novalis ou Hölderlin. Fichte, nota Poliakov, teria sido o primeiro a interrogar-se sobre as origens étnicas de Jesus e a concluir que talvez o nazareno não fosse verdadeiramente judeu, afastando assim o obstáculo a uma religião realmente germânica.

Quanto ao mito das origens do povo alemão, ele se confunde com a mitologia da origem da própria humanidade. Os estudos tradicionais situavam a origem do homem ao leste da Judéia, mas os "cientistas" do iluminismo, sobretudo os geógrafos, tendo conhecimento da presença de vestígios de animais marinhos em todas as altitudes, o que corroborava a hipótese do dilúvio, buscavam no topo das montanhas (que teriam naturalmente escapado da inundação) a origem do gênero humano. E, como se sabia na época, as montanhas mais altas estavam localizadas na Índia, desconsiderando-se os acidentes geográficos da China. E Kant, que como sabemos era geógrafo além de filósofo (um orgulho para os geógrafos ainda hoje) não hesitou em situar as origens da humanidade no Tibete, o país mais "elevado" (em altitude), e por isso muito provavelmente dali teria irradiado toda religião e cultura. Herder por sua vez introduziu na Alemanha a indomania, concepção que a partir daí iria assombrar constantemente a

\footnotetext{
${ }^{24}$ Poliakov, L. O mito ariano, p. 85-94.
} 
imaginação dos românticos até hoje. Como pastor luterano, Johann-Gottfried Herder não temia negar à terra dos hebreus o papel de centro difusor da humanidade, enquanto tecia elogios aos indianos, como se vê, "a Alemanha, preocupada em livrar-se das peias judeo-cristãs, não tardou em responder a esse desejo: com Schopenhauer, ela pretendeu ser filha da Índia, e budista, com Nietzsche, filha do Irã, adepta de Zaratustra” ${ }^{25}$. O que explica, no que diz respeito a Nietzsche, o horror com que o filósofo recebeu o namoro de Wagner não só com o paganismo mas com o cristianismo.

Porém, sobre esse assunto, a lingüística ainda não havia dado sua contribuição. Por mais que se concordasse que todos os homens descendiam de Adão, ainda havia espaço suficiente para se especular sobre qual a língua falada por ele. Até o século XVIII, como demonstra a Enciclopédie, dominava a idéia de que esse idioma seria o hebraico, mas na Alemanha, desde a idade média, já existia a lenda de um Adão germânico.

Com a abertura da Índia aos europeus, muitos estudiosos da língua passaram a notar a semelhança entre os vocábulos europeus e asiáticos (século XVI) e com o impulso oferecido pela indomania as explorações lingüísticas levaram à descoberta do parentesco entre o sânscrito e o latim, linha de pesquisa que levou o jurista inglês William Jones, em 1788, que trabalhava em Bengala (e portanto conhecia o idioma local) a supor que o sânscrito, o grego, o latim e as línguas célticas e góticas teriam derivado de um ancestral comum, o que deu origem à descoberta da família das línguas indo-européias. Porém, apenas 30 anos depois é que Franz Bopp conseguiu provar cientificamente a tese de Jones. No início do século XIX, o romancista, historiador e diplomata Friedrich Schlegel (integrante da primeira geração de românticos) divulgou a novidade entre o público culto, concluindo porém do parentesco da língua um parentesco da raça, inflamando a Alemanha com o mito de uma raça ariana.

Mas naquela época, pelo menos no caso de Schlegel, que era um árduo defensor da emancipação dos judeus, a concepção de uma raça ariana não implicava em antisemitismo. Ainda de acordo com o romancista, um novo povo havia se formado no norte da Índia, que impelido por necessidades elevadas havia emigrado para o oeste, colonizando o resto do mundo. Mas tais colônias teriam sido fundadas por guerreiros ou por sacerdotes? O romantismo de Schlegel o predispunha a crer que os sacerdotes seriam a casta mais apropriada para tal tarefa. Uma hipótese ainda mais fantástica era a

\footnotetext{
${ }^{25}$ Idem, ibidem, p. 166.
} 
suposição de um "crime original", que teria convertido os pacíficos vegetarianos da Índia em carnívoros, agora impelidos a partir para longe de sua terra. Essa "antropodicéia vegetariana", nota Poliakov, seria "retomada e desenvolvida por Richard Wagner, expurgada de toda referência ao mito bíblico"26.

Depois de Schlegel, proliferaram as idéias de que a Alemanha seria o oriente da Europa, de onde o gênero humano poderia ser regenerado, enquanto os personagens bíblicos eram convertidos à nova fé orientalista: o judaísmo seria um "bramanismo primitivo", Abraão-Brahma e Sara-Saravardi eram brâmanes; Esaú representava Arimã; Jacó era Ormuzd e José era Ganesha. Schopenhauer, nessa época, elaborava seu sistema filosófico que se converteria em um dos mais influentes argumentos pró-indianos, próarianos e também antijudeus e anti-semitas. Mas ainda faltava cunhar os termos. A expressão ariano, emprestada de Heródoto (por Anquetil du Peyron) para designar os persas e os medos (e assim utilizados pelos autores alemães), recebeu de Schlegel sua justificação "etimológica", que ligou a raiz ari ao vocábulo germânico Ehre, ou seja, "honra". Quanto ao termo indo-germanos, ele foi forjado por Julius von Klaproth em 1823 e amplamente utilizado pelos alemães, enquanto que os demais países preferiam o termo indo-europeus. Daí por diante, o caminho seria "a anexação de uma ciência verdadeira e fecunda, a lingüística, por uma ciência delirante, a 'antropologia' racial, e a seguir e sobretudo, a influência das paixões políticas sobre o curso tomado pelos extravios antropológicos" 27 . Em resumo, o termo "ariano" veio designar uma obscura e anônima raça ancestral formada no norte da Índia e que de lá teria civilizado o ocidente, começando pela Escandinávia, e a semelhança linguística serviu para provar que "nórdicos" e indianos formariam uma mesma raça. Com o advento do nazismo, porém, o termo ariano vinculou-se definitivamente aos alemães e ao fenótipo "loiro de olhos azuis", também característico de outros povos do norte da Europa.

Enquanto Goethe era hostil à indomania, Schelling a defendera por algum tempo antes de converter-se ao luteranismo. Já Hegel comparava a descoberta do sânscrito á descoberta de um novo continente, porém, por mais que considerasse a Índia como um país anterior a toda a história, desprezava a cultura indiana. Apesar dos precursores Karl Ritter (que privilegiava a Índia) e Johann Gottfried Rhode (que pregava a superioridade de Zoroastro contra Moisés), foi com o indianista Christian Lassen, ligado aos irmãos Schlegel, que em 1845 a oposição entre a raça indo-germânica (contempladores das

\footnotetext{
${ }^{26}$ Poliakov, L. O mito ariano, p. 171.

${ }^{27}$ Idem, Ibidem, p. 172.
} 
idéias puras e de talentos superiores) e os semitas (egoístas, exclusivistas e sem refinamento) se estabeleceu. Com Jakob Grimm, nessa mesma época, o mito da superioridade indo-germânica ou ariana (por mais que ele não utilizasse esses termos, mas "Deutsche") se estabeleceu e é com sua obra (como a clássica História e Língua Alemã) que o mito atingiria um público mais vasto. Esse mito, que na verdade era o mito da migração da Ásia para a Europa com a posterior impregnação de anti-semitismo que opunha arianos a semitas, rapidamente difundiu-se pela Europa. Apesar da importância de Gobineau (que discutiremos a seguir), Poliakov aponta que o verdadeiro responsável científico pela propagação do arianismo na França teria sido Ernest Renan, um apaixonado pela Alemanha. Para Renan, os semitas eram página virada na história, já haviam cumprido sua missão e agora o essencial a ser feito ficava a cargo dos germanos e celtas - o futuro da humanidade, graças à sua razão e à sua ciência. Nele, confundia-se raça semita com raça judia e sua preferência recaía sobre a terminologia de raça ariana para representar a raça germânica ou raça indo-européia ${ }^{28}$.

\section{Os pressupostos psicossociais de uma filosofia de veterinários}

No final do século XVIII, sobretudo na França e na Alemanha, as teorias sobre a origem dos homens calcadas na genealogia bíblica abandonaram o cenário intelectual, dando espaço às teorias "científicas". É claro que, como já pudemos notar, a ciência muitas vezes só consegue empurrar velhas crenças para o subterrâneo da cultura, de onde elas seguem seu curso rivalizando com aquela que lhe tomou o lugar, na maioria das vezes de forma silenciosa, ressurgindo aqui e ali.

Pois bem, na França, Lamarck desenvolvia sua tese de que as espécies animais descendiam umas das outras e progrediam passando aos seus descendentes os caracteres adquiridos sob a ação do ambiente. Na Inglaterra, Erasmo Darwin (não confundir com Charles Darwin) formulava uma hipótese semelhante à de Lamarck, acrescentando que essa progressão tinha origem na competição pela sobrevivência ou pelas fêmeas. Essas correntes de pensamento ligavam-se, de certa forma, à tradição cultural do país em que se desenvolveram: no primeiro caso, as doutrinas do progresso racial e psicológico; no segundo, a doutrina do progresso racial e econômico, de viés individualista e pregando a competição entre os indivíduos. No caso da Alemanha, muito menos influente nesse

\footnotetext{
${ }^{28}$ Idem, ibidem, p. 174-188.
} 
processo, as teorias da evolução biológica surgiram vinculadas à filosofia da natureza, "que via as espécies orgânicas como outras tantas realizações materiais separadas e sem conexão com os diferentes estágios, através dos quais passaria o Espírito do Universo, durante o curso do seu automovimento interior em direção do seu objetivo - o homem" 29 , ou seja, a idéia predominante nesse caso era a preocupação com a História e a tradição mística dos alquimistas.

Mas o principal nome dessa época foi mesmo, como sabemos, Charles Darwin (1809-1882). Sua teoria acerca da evolução das espécies, influenciada por Malthus (que acreditava que o crescimento da população excedia em muito a disponibilidade de alimentos), supunha que as criaturas ramificavam-se a partir de ancestrais comuns, sendo que algumas formas desapareciam por extinção enquanto outras se desenvolviam sobrevivendo através de seus descendentes. Aplicando a mesma lógica de qualquer dono de granja ao selecionar suas galinhas, Darwin supôs que na natureza os animais também eram selecionados. Como cada ninhada de animais produz descendentes com características diferentes (os trabalhos do monge austríaco Gregor Mendel explicariam, no futuro, esse fenômeno), a natureza selecionaria os indivíduos cujas características seriam mais favoráveis à adaptação ao ambiente, fazendo perecer os demais. Após milhares de anos, o mesmo processo que criou a variabilidade dentro de uma mesma espécie poderia dar origem a novas espécies e posteriormente a novos gêneros e ordens. Diferente do que se imagina, a principal diferença entre a teoria de Darwin e aquela de Lamarck não diz respeito à negação por Darwin da hipótese da herança das características adquiridas através do uso ou desuso dos órgãos formulada por Lamarck, porque na sexta edição de As origens das espécies Darwin aceita essa hipótese ${ }^{30}$. Aquilo que ele nunca aceitou foi a idéia de uma força impulsora interna, absolutamente contrária à sua concepção de uma evolução orgânica passiva, impulsionada por mecanismos externos.

Herbert Spencer (1820-1903), também influenciado por Malthus e agora apoiado em Darwin, pregava a idéia de um progresso automático, pois se não havia uma propulsão interior, mas uma pressão seletiva proveniente do exterior, o progresso era independente do esforço humano. A "sobrevivência do mais adaptado" (expressão de Spencer), consequiência da seleção natural, foi estendida por ele para a sociedade humana e apontada como justificativa da política do laissez-faire do período vitoriano,

\footnotetext{
${ }^{29}$ Mason, S. F., História da ciência, p. 336.

${ }^{30}$ Sobre essa curiosa alteração no pensamento de Darwin, ver Mason, S. F., História da ciência, p. 342.
} 
ou seja, a liberdade comercial e a livre competição constituiriam o aspecto social da seleção natural. Sendo assim, "interferir neles seria o mesmo que intrometer-se com o progresso da evolução cósmica, e poderia desengrenar o veículo do progresso humano"31.

Ao romper os limites da Biologia - contaminando disciplinas como a Química e a Antropologia - e em seguida rompendo os limites mesmos da ciência ao atingir a Filosofia e a moral, o darwinismo deu origem à escola do darwinismo social. Toda mudança era considerada automática, gradual e continuada, e a história estava cheia de exemplos, com as nações mais poderosas dominando as mais fracas e assim propagando suas melhores qualidades, que tendiam obviamente para o bem. $\mathrm{O}$ real, diriam os darwinistas sociais se fossem hegelianos, é certamente racional. Mas os biólogos mesmo, afirma Mason, não aceitavam inteiramente essa apropriação pela sociologia, filosofia e sobretudo pela economia do darwinismo, e o próprio Darwin pregava em $A$ descendência do homem que o progresso da humanidade devia-se ao "crescente domínio da cooperação sobre os instintos egoísticos" ${ }^{\text {32 }}$.

Mesmo com sua origem vinculada à Inglaterra, o darwinismo foi negado nos países de língua inglesa e mesmo na França (como foi o caso do microbiologista Louis Pasteur). Na Alemanha, porém, o darwinismo foi mais largamente difundido e debatido, sempre em oposição às concepções da "filosofia da natureza", o que imprimiu, nesse país, características peculiares à doutrina evolucionista. Por isso convém comentar, antes de prosseguirmos, os pressupostos da Naturphilosophie.

O método escolhido pelos alemães para interpretar os fenômenos da natureza, como bem indicava a crítica de Goethe ao materialismo mecanicista de Holbach apresentado em seu Sistema da natureza, era diferente daquele dos franceses, inspirado em Descartes. Para os alemães, as faculdades do espírito humano não podiam ser analisadas em termos de matéria em movimento condicionada pela fisiologia ou estímulos externos:

\footnotetext{
"Os alemães eram mais introspectivos. Interessavam-se pela atividade própria do espírito humano, pela percepção interior - segundo a expressão de Goethe - daquilo que parecia ser o livre-arbítrio e de algo que limitava e contrabalançava dita liberdade. Os filósofos alemães eram de opinião que o universo estava saturado por uma atividade espiritual análoga, e assim os processos da natureza deviam ser interpretados por
}

\footnotetext{
${ }^{31}$ Mason, S. F., História da ciência, p. 343.

${ }^{32}$ Idem, ibidem, p. 345.
} 
analogia, em comparação com o movimento interno do espírito, e não em termos da sua exterioridade da matéria em movimento" ${ }^{33}$.

Para o místico Jacob Boehme (1575-1624) o homem era uma cópia perfeita em miniatura do universo, e por isso era possível tecer uma analogia entre o desenvolvimento espiritual do homem e o desenvolvimento do universo. Por mais que os ensinamentos de Boehme sejam creditados a supostas "iluminações" místicas, seu argumento fazia eco à idéia da Iatroquímica de Paracelso, que supunha não existir matéria inerte, e que todas as substâncias - incluindo os minerais - eram vivas, autônomas e movidas por uma força vital. A influência das idéias dos alquimistas também podia ser sentida. Na filosofia da natureza de Leibniz (1646-1716) a preocupação era com a estrutura do mundo e das criaturas, onde a força ativa espiritual das mônadas (também um microcosmo refletindo a totalidade do universo) era contraposta à concepção newtoniana dos átomos materiais inertes.

Mas é com Schelling (1775-1854) que as idéias principais da Naturphilosophie alemã se constituem. Conciliando as idéias de Boehme e Leibniz, Schelling concebe o homem como síntese do universo inteiro, um microcosmo complexo porque produto final do desenvolvimento do mundo. Dessa forma, as leis do espírito seriam idênticas às leis da natureza.

Levando em conta essas características da Naturphilosophie, é compreensível que na Alemanha Darwin tenha suscitado bastante controvérsia, sendo rejeitado, sobretudo, pelos cientistas mais velhos. Porém, um nome em especial se destaca: o de Carl Nageli (1817-1891). Simpático às idéias de Darwin, mas fortemente influenciado pela Naturphilosophie, esse professor de botânica sustentava que as criaturas vivas estavam sempre sendo geradas de forma espontânea e evoluindo a formas mais elevadas graças a uma "força interna" (de caráter mecânico). Entre homens e macacos, afirmava, não existia qualquer tipo de parentesco. $\mathrm{O}$ homem havia sido gerado espontaneamente a partir de seres unicelulares, ocorrendo o mesmo com os gorilas e mais tarde com os macacos, mesmo assim, os símios de hoje seriam os homens de amanhã. A evolução não se daria de forma gradual, mas em saltos. Apesar disso, Nageli propôs teorias bastante promissoras ao supor que os pais contribuíam igualmente para a descendência e que havia no ovo uma substância determinante da hereditariedade (que estavam de

\footnotetext{
${ }^{33}$ Idem, ibidem, p. 282.
} 
acordo e foram confirmadas pelas pesquisas de Mendel) que ele chamou de idioplasma ${ }^{34}$.

Enquanto isso, em 1853, na França, o Conde de Gobineau publicava o seu Ensaio sobre a desigualdade das raças humanas. Conhecedor dos principais biólogos da época, Gobineau atinha-se ainda à cronologia bíblica (o universo não contava com mais de cinco ou seis mil anos), e para ele, o livro do Gênesis tratava apenas da humanidade branca - forte, bela e inteligente. Raça essa proveniente da Ásia setentrional e depois dividida em três ramos: Cam, Sem e Jafé, sendo que deste último surgiriam os futuros arianos. Apesar de acreditar no monopólio da beleza da raça branca, Gobineau considerava os judeus pertencentes a essa raça. Seu problema estava com os negros e com a mistura de raças, pois segundo ele haveria um "instinto racial" que faria oposição ("lei de repulsão") aos cruzamentos entre raças diferentes. Mas, por conta da própria sociabilidade da raça branca, essa lei de repulsão teria se invertido, convertendo-se em lei de atração, levando-os a miscigenar-se com raças inferiores e dando origem a sub-raças degeneradas, cuja conseqüência seria o fim da espécie humana pela degenerescência física e intelectual.

\footnotetext{
"A espécie branca doravante desapareceu da face do mundo. Depois de ter passado pela era dos deuses, quando era absolutamente pura; pela idade dos heróis, quando as misturas eram moderadas em força e em número; pela era das nobrezas, quando as faculdades, ainda grandes, não eram mais renovadas por fontes exauridas, encaminhouse mais ou menos prontamente, segundo os lugares, para a confusão definitiva de todos os seus princípios (...) A parcela de sangue ariano, já tantas vezes subdividida, que ainda existe em nossas regiões, e que sustenta sozinha o edifício de nossa sociedade, encaminha-se dia a dia para os termos extremos de sua absorção. Obtido este resultado, abrir-se-á a era da unidade... Este estado de fusão, longe de ser o resultado do casamento direto dos três grandes tipos tomados no estado puro, será apenas o caputi mortuum de uma série infinita de misturas, e por conseguinte defenecimentos; último termo da mediocridade em todos os gêneros, mediocridade de força física, mediocridade de beleza, mediocridade de aptidões intelectuais, pode-se dizer, quase um nada" 35 .
}

Gobineau, que nascera em uma família humilde, não tardou a reivindicar para si uma falsa genealogia aristocrática, auto-intitulando-se conde antes de tornar-se

\footnotetext{
${ }^{34}$ Idem, ibidem, p. 349.

${ }^{35}$ Gobineau, A. Essai sur l'inegalité des races humaines, p. 208, citado por Poliakov, L. O mito ariano, p. 220.
} 
diplomata, quando pôde viajar pelo mundo certificando-se de suas hipóteses racistas. Em uma dessas viagens o conde conheceu o Brasil, travando amizade com D. Pedro II. Gobineau ficou escandalizado com a mistura racial brasileira, achando a população toda mulata ${ }^{36}$ - absolutamente repugnante. Tal miscigenação haveria de selar a sorte do país, conduzindo a população do Brasil ao desaparecimento. A única saída seria o incentivo à imigração de raças européias "superiores". Os eugenistas (e os higienistas), no futuro, desenvolveriam estratégias mais sofisticadas que a sugerida por Gobineau. Seu trabalho não alcançou na França o sucesso esperado, mas na Alemanha, obcecada pela pergunta "Que é ser alemão?" aludida por Nietzsche, a recepção seria bem mais calorosa.

A Naturphilosophie preparara o terreno para a aceitação das idéias de Gobineau. Schelling, na sua Filosofia da Mitologia, nota Poliakov, dividia o gênero humano em dois grandes blocos, de um lado os humanos brancos e de outro os negros africanos e os indígenas da América, próximos da animalidade. Essas raças, confirmando as práticas coloniais da época, estavam voltadas à escravidão ou à extinção ${ }^{37}$. Difícil explicar como exatamente Schelling conseguiu saltar da idéia do homem como síntese do universo inteiro, para a conclusão de que essa lógica só se aplicava aos homens brancos.

As questões fundamentais levantadas pelo trabalho de Darwin haveriam de se encontrar, inevitavelmente, com as especulações dos antropólogos e dos lingüistas quanto à origem do homem, acrescentando a estas, sob o viés do darwinismo social e da eugenia, uma preocupação mais prática: a raça humana, em processo de degradação, precisava ser salva. Surgia assim, logo após o lançamento de A origem das espécies, através de Francis Galton, primo de Charles Darwin, as formulações que inaugurariam uma tentativa (do ponto de vista biológico) de melhorar a raça humana.

O palco onde todo esse processo iria surgir era a Inglaterra burguesa do século XIX, onde algumas décadas após a Revolução Industrial, em grandes cidades como Londres, uma multidão de proletários se amontoava em cortiços e no interior das fábricas. A multidão, sentida como um todo homogêneo, disforme e compacto - a massa - esse fenômeno moderno, assustava e o medo gerado pela multidão estimulava estratégias de combate para sanar esse medo. Como resultado do crescimento urbano, a população da cidade de Londres já atingira, em 1890, a cifra de mais de quatro milhões

\footnotetext{
${ }^{36}$ O termo "mulato" provém de "mulo", similar à designação "mestiço", utilizada no caso dos indígenas. Supunha-se, claro, que eles fossem estéreis.

${ }^{37}$ Poliakov, L. O mito ariano, p. 223.
} 
de habitantes. Para o homem de hoje, cidades com dez milhões de habitantes são fáceis de imaginar: prédios luxuosos, casas de classe média, favelas com eletricidade, supermercados, farmácias, indústrias higiênicas e ruas de comércio popular, tudo isso agitado por episódios de violência descontrolada e por uma criminalidade endêmica. Mas na Londres do século XIX tudo isso era novo e assustador. Entre os intelectuais, o darwinismo social e as idéias degeneracionistas eram freqüentemente debatidas:

\begin{abstract}
"Darwinistas sociais acreditavam que a multidão que vivia nos bairros operários de Londres estava degenerando, ou seja, pobreza associada à degeneração física. Reurbanização, disciplina e políticas de higiene pública deveriam ser aplicadas com a finalidade de prevenir a degradação física dos trabalhadores para evitar prejuízos na economia que reverteriam em menos dividendos para a burguesia. Essa situação desdobrou-se ao longo do século XIX e causou tanto impacto na Inglaterra que gerou um preconceito contra o trabalhador londrino, por ele ser mais fraco e apático do que o trabalhador vindo e criado no campo" ${ }^{\Perp 38}$.
\end{abstract}

André Pichot aponta que no final do século XIX a "degeneração" era uma moda, tanto nos consultórios quanto nos salões. Degenerava-se por doença, como no caso da tuberculose, por intoxicação, com o uso abusivo do álcool pelos proletários e do ópio pelos burgueses; por consangüinidade, caso da degeneração da família real com seus hemofílicos; degenerava-se por conta do declínio da civilização que perdia suas boas maneiras com o avanço da industrialização e a expansão do proletariado; e degeneravase, também, por mestiçagens, já que a colonização havia aumentado o contato com outras nações, sobretudo com os negros. E ao mesmo tempo, apesar da crença generalizada na degradação, acreditava-se no progresso da ciência:

\footnotetext{
"Simultaneamente, nos mesmos consultórios médicos e nos mesmos salões, a humanidade progredia a passos de gigante. Por todo o lado se celebrava a ciência. A medicina acabava de ser revolucionada por Pasteur; as doenças recuavam frente às vacinas, à higiene e à assepsia, à espera dos primeiros antibióticos. A mecanização triunfava, as máquinas funcionavam, a indústria produzia, os automóveis começavam a rolar e os aviões a voar. A eletricidade alumiava o mundo, o rádio irradiava-o, o urânio em breve o iluminaria. Face à degenerescência generalizada (da saúde, dos costumes, da
}

\footnotetext{
${ }^{38}$ Diwan, P. Raça pura: uma história da eugenia no Brasil e no mundo, p. 35.
} 
política e da arte), a ciência e a técnica erguiam-se, últimos bastiões da humanidade e da civilização" 39 .

Se havia alguma certeza naquela época, era a de que tudo degenerava. E com a segunda revolução industrial e a crise agrícola do final do século as contradições se tornavam mais agudas, com greves e manifestações que ameaçavam o bom desenvolvimento do capitalismo e culminariam na criação do Independent Labour Party em 1893. Dentre as diversas conquistas dos trabalhadores contava-se o surgimento do Welfare State - Estado de Bem-Estar Social - que forçava o Estado a atender as necessidades dos trabalhadores com a criação de serviços estatais de amparo aos mais necessitados. Enquanto isso, higienistas e eugenistas tentavam aliviar as tensões sociais à sua maneira, sobretudo no que dizia respeito àquelas pessoas que não tinham a vida regulada pelo trabalho, ou seja, os "vagabundos", e também os loucos e os doentes. A proposta dos higienistas de uma reforma moral da sociedade (como se vê, eles não estavam preocupados apenas com a saúde), na visão dos eugenistas não era suficiente porque ela não resolvia a questão dos indigentes, dos mendigos e dos delinqüentes, permitindo que eles se reproduzissem, afinal, "melhorar as condições de vida dos grupos de degenerados era o mesmo que incentivar a degeneração da "raça inglesa",40. Por isso, para os eugenistas,

\footnotetext{
"o Welfare State era anti-natural, e permitir que o menos apto viva, através do assistencialismo, era considerado parasitismo. Nesse sentido, combater esse tipo de parasitismo era contribuir para o progresso da sociedade, já que, com a eliminação do fardo social que sobrecarrega o Estado, o progresso da civilização estaria garantido. Isso quer dizer que o grande impedimento para o sucesso da eugenia dependia de poupar os nascimentos daqueles que invariavelmente viveriam sob a tutela do Estado, alem de estimular os casamentos e a procriação daqueles que elevariam o conjunto da raça inglesa” ${ }^{, 4}$.
}

O trabalho de Darwin, importa notar, já havia sido publicado há três décadas e boa parte desses debates sofrera sua influência, por mais que em A origem das espécies Darwin não fale diretamente do homem. Porém, Clémence Royer, ao traduzir a obra para o francês, inclui um longo prefácio em que, aproveitando as referências a Malthus,

\footnotetext{
${ }^{39}$ Pichot, A. O eugenismo: geneticistas apanhados pela filantropia, p. 13.

${ }^{40}$ Diwan, P. Raça pura: uma história da eugenia no Brasil e no mundo, p. 37.

${ }^{41}$ Idem ibidem, p. 37.
} 
a aplicação do darwinismo aos seres humanos surge sem ambigüidades. Nesse prefácio, Clémence Royer critica a legislação vigente e a moral religiosa por conta de sua insistência em prestar caridade a "seres mal constituídos", moral essa que a democracia pensava em institucionalizar sob a forma de uma solidariedade obrigatória que só multiplicaria os males que pretendia remediar. De acordo com a tradutora, seria irracional sacrificar o forte pelo fraco, o bom pelo mal, os seres bem dotados de espírito e corpo pelos viciosos e doentios, e essa opção pelos fracos e pelos inválidos serviria apenas para perpetuar o mal, fazendo-o aumentar ao invés de diminuir. O amor e a piedade, resume, não deveriam ser desperdiçados com os decadentes e os degenerados da espécie ${ }^{42}$. Um discurso que todos os conservadores, em todos os tempos, haverão de repetir à exaustão, dos líderes nazistas àqueles que hoje criticam os direitos humanos como "direitos humanos dos bandidos".

Mas Darwin, que não escreveu esse prefácio, nem por isso pode ser poupado, porque ao falar do homem em 1871, em La Descendance de l'homme et la Sélection Sexuelle chegou a afirmar que

"Entre os selvagens, os indivíduos fracos de corpo ou de espírito são imediatamente eliminados, destacando-se normalmente os sobreviventes pelo seu vigoroso estado de saúde. Quanto a nós, homens civilizados, fazemos, pelo contrário, todos os esforços para parar a marcha da eliminação; construímos hospitais para os idiotas, os inválidos e os doentes; fazemos leis para socorrer os indigentes; os médicos empregam toda a sua ciência para prolongar tanto quanto possível a vida de cada um (...) Os membros débeis das sociedades civilizadas podem mesmo reproduzir-se indefinidamente. Ora, quem se tenha ocupado da reprodução dos animais domésticos sabe, sem lugar para dúvidas, como essa perpetuação dos seres débeis deve ser nociva à raça humana"43.

Como se vê, essa filosofia de veterinários (a expressão é de Poliakov) era mesmo muito bem aceita na Inglaterra e na Europa no final do século XIX. A questão a ser respondida: podemos desculpá-los argumentando que eles seriam "homens de sua época"? As gerações futuras haverão de nos considerar "indesculpáveis" por aplicarmos técnicas de eugenia em nossas fazendas de gado?

\footnotetext{
${ }^{42}$ Royer, C. prefácio à tradução (1862) de L'Origine des espèces, p. xxxiv-xxxv, citado por Pichot, A. O eugenismo: geneticistas apanhados pela filantropia, p. 16-17.

${ }^{43}$ Darwin, C. La Descendance de l'homme et la Sélection Sexuelle, citado por Pichot, A. O eugenismo: geneticistas apanhados pela filantropia, p. 17-18.
} 
O impulso inicial dado pela teoria da evolução será desenvolvido por Francis Galton, primo e colaborador de Darwin. Nascido no seio de uma família burguesa da Inglaterra vitoriana, cujos antepassados estavam ligados aos estudos científicos, Galton se viu obrigado pelo pai a estudar medicina. Após muita insistência, consegue demover o pai da idéia de vê-lo formado médico, e decide estudar matemática em Cambridge. Como não obtém sucesso em sua nova carreira, retorna à medicina até a morte do pai em 1844. Herdeiro de uma fortuna considerável, ele abandona definitivamente os estudos médicos para viajar pelo mundo como explorador nomeado pela Sociedade Real de Geografia, recolhendo dados etnográficos no Egito, Angola, África inglesa e África do Sul. Como pesquisador do laboratório Kew na Inglaterra, estudou os ciclones e descobriu os anticiclones.

O lançamento do livro de seu primo Charles Darwin veio arrancar Galton de um momento de crise, quando seus trabalhos como meteorologista estavam sendo criticados, para lançá-lo no caminho do aperfeiçoamento da raça humana. Por algum tempo os trabalhos de Darwin e de Galton coincidiram, isso até Darwin criar sua teoria que ajudava a elucidar o mecanismo através do qual as "gêmulas" presentes em todo organismo seriam transmitidas para a sua descendência. Essa teoria da transmissão hereditária ficou conhecida como teoria da "pangênese", que daria origem no futuro ao termo "gene" e conseqüentemente a um novo ramo da biologia, a "genética". O problema na teoria da "pangênese" de Darwin é que ela afirmava que as tais "gêmulas" poderiam ser alteradas pelo meio ambiente. Ora, aqui fica fácil perceber a importância do problema que separou os dois cientistas: qualquer esforço para a melhoria da raça não poderia contar com o acaso de mutações devidas ao ambiente. Galton precisava discordar de Darwin nesse ponto e o rompimento tornou-se inevitável.

No mesmo ano do rompimento com Darwin, em 1865, Galton publica seu primeiro trabalho, Hereditary Talent and Character, seguido três anos depois por Hereditary Genius (1869). O objetivo de Galton com esses trabalhos é o de provar, a partir do estudo da distribuição do talento nas populações, que o talento seria hereditário e não resultado do meio ambiente, o que reacendeu o debate entre natureza e cultura. Com o seu trabalho sobre hereditariedade - A theory of hereditary - publicado em 1875, baseando na teoria de Weismann sobre o plasma germinal, Galton indica o rumo de seu novo interesse: o cruzamento de ervilhas e o estudo das medidas antropológicas. $\mathrm{O}$ leitor deve estar se perguntando se não estaríamos confundindo Galton com Mendel (1822-1884) nessa história de ervilhas. Seria uma boa objeção, mas o que se passa é que 
os trabalhos de Mendel só seriam descobertos, ou melhor, redescobertos em 1900, mais de duas décadas após esses trabalhos de Galton (a história da ciência tem dessas coisas...). A pesquisa com ervilhas e medidas antropológicas tinha como objetivo a seleção dos mais aptos e a exclusão dos inaptos, principal interesse da eugenia, que estava prestes a nascer como expressão.

E, curiosamente, nessa mesma época, o médico Cesare Lombroso publicava, sob a influência de Darwin e dos frenologistas, um clássico da antropologia criminal: L'uomo delinqüiente (1876), que pretendia, através do estudo de certas deformações no esqueleto, no crânio e na assimetria crânio-facial, identificar sinais de degenerescência física (novamente a idéia de que tudo degenera) que caracterizava os criminosos:

“A par destes sinais físicos, [Lombroso] apontava a ausência de sensibilidade moral, manifestações de vaidade, crueldade, indolência, uso do calão próprio dos delinqüentes uma específica insensibilidade nervosa à dor perante a morte e o sofrimento e, finalmente, uma inclinação para a tatuagem, fato que já antes tinha observado entre os soldados. Este criminoso congênito, este imbecil moral é um tipo atávico, isto é, representa uma regressão aos primeiros e primitivos tipos humanos, ou mesmo aos ancestrais pré-humanos com instintos canibalísticos"44.

Isso nos mostra que as idéias em que Galton se apoiou para instituir a eugenia como um ramo da biologia já estavam disseminadas pela cultura em uma forma précientífica, ou o que é mais importante, já existiam como um capítulo da história da magia e mais especificamente das artes divinatórias. Entre a quiromancia e a fisionomia a distância é muito pequena; a mesma que separa os fisionomistas dos frenologistas do século XVIII e princípio do século XIX. Como não queremos ir tão longe quanto a Hipócrates e Aristóteles, já ficaremos satisfeitos situando a origem "moderna" dessa noção em uma obra cujo título é bastante sugestivo; o De humane physionomia (1586) de Gian-Battista della Porta. O físico napolitano della Porta entendia a fisionomia como um método para conhecer os hábitos e a natureza humana a partir de sinais permanentes no corpo, estudando minuciosamente a cabeça, os cabelos, as orelhas, o nariz, os dentes, etc. Mas o estudo da fisionomia chegará ao século XIX e XX através do trabalho de Caspar Lavater (1741-1800), De la Physiognomonique, cujo objetivo ainda era religioso: ele queria "dar ao público os meios de fugir das pessoas maldosas e de

\footnotetext{
${ }^{44}$ Mannheim, H., Criminologia comparada, p. 320.
} 
escolher bons amigos" ${ }^{45}$. A frenologia, já depurada de interesses religiosos (mas não morais), aceitava haver uma estreita correspondência entre a configuração exterior do crânio e a estrutura cerebral e sua principal aplicação era o estudo dos crânios de delinqüentes (novamente, o interesse pelos degenerados...). Mas a fama da frenologia e, de certa forma, da fisionomia ainda no século XX deve ser creditada a Lombroso.

Galton também tinha em mente provar que a doença mental, o crime e a vagabundagem eram formas de degeneração resultante da herança genética, assim como o talento da aristocracia. Depois de sua aventura com as ervilhas, a partir da reunião de um vasto material antropológico, ele publica Inquires into Human Faculty and its Development (1883), em que ele utiliza explicitamente pela primeira vez o termo eugenia:

\begin{abstract}
"mencionar vários tópicos mais ou menos conectados com aquele do cultivo da raça, ou, como podemos chamá-los, com as questões 'eugênicas'. Isto é, com problemas relacionados com o que se chama em grego 'eugenes', quer dizer, de boa linhagem, dotado hereditariamente com nobres qualidades. Esta e as palavras relacionadas, 'eugeneia' etc são igualmente aplicáveis aos homens, aos brutos e às plantas. Desejamos ardentemente uma palavra breve que expresse a ciência do melhoramento da linhagem, que não está de nenhuma maneira restrita a união procriativa, senão, especialmente no caso dos homens, a tomar conhecimento de todas as influências que tendem em qualquer grau. Por mais remoto que seja, dar às raças ou linhagens sanguíneas mais convenientes uma melhor possibilidade de prevalecer rapidamente sobre os menos convenientes, que de outra forma não haja acontecido" ${ }^{46}$.
\end{abstract}

$\mathrm{Na}$ Alemanha, a principal herdeira da eugenia (lugar onde suas técnicas abandonariam o uso veterinário mais óbvio e desatariam os últimos laços que a ligavam a preceitos morais capazes de impedir que se extraísse da eugenia suas últimas conseqüências), o pensamento eugênico ligou-se ao biólogo August Weismann (18341914). Considerado um dos fundadores da genética moderna, Weismann acreditava que o plasma germinativo, que hoje conhecemos por gametas (óvulos e espermatozóides) contava com a propriedade de permanecer idêntico, geração após geração. Mesmo hoje parece razoável acreditarmos nisso, mas devemos lembrar que Darwin já nos alertava em sua "pangênese" que as "gêmulas" poderiam ser alteradas pela ação do meio

\footnotetext{
${ }^{45}$ Alexandrian, História da filosofia oculta, p. 218-222.

${ }^{46}$ Francis Galton, Inquires into Human Faculty and its Development (1883), p. 17, citado por Diwan, P., Raça pura: uma história da eugenia no Brasil e no mundo, p. 41-42.
} 
ambiente e que tais alterações seriam transmitidas às gerações futuras. Trata-se, de certa forma, de um tipo de transmissão de "características adquiridas", mas obviamente diferente daquela proposta por Lamarck.

Pois bem, para o neodarwinista Weismann, a criança não era parecida com os pais porque representava a fusão das características daqueles, e sim porque tanto a criança quanto seus pais conteriam em si o patrimônio genético de todos os seus antepassados. Sendo assim, "pais e filhos, oriundos de um mesmo plasma germinativo, já não surgem apenas como genitores e progenitura, que se sucedem no tempo, mas também como 'contemporâneos genéticos', germanos tendo em vista uma identidade hereditária imortal ou atemporal" ${ }^{\prime 4}$.

A diferença pode parecer sutil, mas não é. Contrariando as formulações de Darwin, Weismann enfatizava a preservação de características já presentes no organismo (logo, imemoriais) em detrimento das idéias darwinistas (e também lamarckistas) de que novas variações poderiam surgir nesse processo graças à ação do meio ambiente. Para ser mais exato, Weismann admitia que as características adquiridas poderiam afetar as células somáticas mas não as germinativas, cuja substância essencial ele chamava de idioplasma. Não é difícil compreender que essa idéia de "continuidade do plasma", também chamado de "plasma dos antepassados" fornecia à Alemanha nazista a base científica para a idéia de uma "herança ancestral".

E tão logo Hitler chegou ao poder, teve início sua diretriz de converter a questão racial no problema dominante do Estado. A conservação da pureza do sangue transformou-se a partir de então em uma questão científica, e as SS foram o seu principal laboratório de purificação racial. Como os comícios de Hitler no começo da década de 1920 não raramente terminavam em pancadaria, o capitão Röhn, oficial do exército de 100.000 homens permitido pelo tratado de Versalhes (conhecido como Reichswehr), ao abandonar o exército arrasta consigo um pequeno grupo de homens que oferece para a defesa do partido. Tem origem aí, em 1921, o agrupamento para-militar do partido nacional-socialista, conhecido como Sturmabteilung (SA ou tropas de assalto) que um ano antes da tomada do poder alcançaria o número de 400.000 homens.

Com Hitler temendo por sua vida, pouco tempo depois, em março de 1923, um pequeno grupo de elite escolhido entre os membros das SA deram origem à Stosstrup Adolf Hitler (tropas de assalto Adolf Hitler) cuja lealdade era incontestável. Essa guarda

\footnotetext{
${ }^{47}$ Conte, E; Essner, C. A demanda da raça: uma antropologia do nazismo, p. 121.
} 
pretoriana, posteriormente rebatizada com o nome de Schutzstaffel (SS), e que tinha primazia sobre as SA, mesmo em 1929, quando Hitler promoveu o ex-estudante de agricultura Heinrich Himmler (então com 29 anos) a Reichsführer das SS, contava com apenas 300 membros. Mas as coisas já estariam bem diferentes dois anos depois, quando o efetivo das SS já atingiria a casa dos milhares e sua função no destino da Alemanha começava a ganhar contornos mais nítidos:

\footnotetext{
"As SS eram o exemplo a ser seguido por todo bom alemão, era o antecedente do que, com o esforço do povo, devia chegar a se converter a nação germânica. Os conceitos da superioridade racial, da mitologia nórdica, da mística dos antigos guerreiros teutônicos e do 'bom ódio' aos judeus encontraram pleno significado nos escuros uniformes da 'Guarda Negra'. Por tudo isso, subentende-se que o símbolo rúnico que portavam, como máximos representantes da nova ordem que se instalaria na Europa, não havia sido escolhido às pressas: a insígnia SS era considerada a inscrição superlativa da escrita rúnica" ${ }^{48}$.
}

Quando Ernst Röhn, homem violento e especialista em táticas militares, cuja experiência podia ser notada através das profundas cicatrizes (marcas de metralhadora) que trazia no rosto, abandonou a Reichswehr com seu grupo armado, o partido nacionalsocialista agradeceu o reforço. Mas a paranóia ou a perspicácia de Hitler lhe diziam que ele não poderia contar com essa milícia por muito tempo. O efetivo das SA eram provenientes das antigas Freikorps (grupos para-militares de direita que proliferaram após a guerra), por soldados da Reichswehr e por um punhado de alcoólatras e criminosos cuja violência mal podia ser contida. Além do mais, esses grupos eram reconhecidos por exibirem lealdade ao comandante de seu destacamento (no caso, Röhn) mais do que a qualquer outro oficial de alta patente e até mesmo ao Führer, o que os tornava sempre uma grande preocupação no caso de um motim. E foi por isso que, mesmo tendo sido criadas por Röhn, as SA ficaram sob o comando (sempre frágil) de Hermann Göring, homem que gozava da confiança de Hitler. Porém, como nota Enriquez acerca da personalidade do paranóico,

\footnotetext{
${ }^{48}$ Cores, P. J. A estratégia de Hitler: as raízes ocultas do nacional-socialismo, p. 117.
} 
"quando ele declara estar rodeado de inimigos, é porque não pode se desenbaraçar de seus próprios inimigos internos. Continuamente submetido a agressões internas, ele precisa encontrar agressores imaginários extermos para não cair na loucura declarada» ${ }^{49}$

O resultado dessa lógica se aplica até mesmo aos amigos, tratados sempre com desconfiança. Por isso Hitler, desconfiando das SA (que poderiam estar planejando um golpe), manda prender e depois executar todos os seus líderes naquilo que ficou conhecido como "a noite dos longos punhais". O único rival sério, Röhn, aquele não havia sucumbido totalmente ao carisma de Hitler mantendo sua independência havia sido eliminado. O poder concentrava-se agora totalmente nas mãos da SS, e de seu líder.

Além do mais, como Hitler pretendia, no futuro, instituir uma nova ordem de guerreiros puros e leais, não podia contar com um grupo de bandoleiros bêbados, criminosos e homossexuais (como era o caso do próprio Röhn). A nova ordem "devia ser o exemplo a ser seguido pelo povo alemão, a raça, a honra, a lealdade permanente para com Hitler, a temeridade, a educação aristocrática nazista, a efetividade na linha de frente e o desejo de morrer pelo regime passariam a fazer parte do espírito das $\mathrm{SS}$ ",

Para conseguir converter essa guarda nos "representantes da nova ordem", era preciso contar com o Departamento de Raça e Colonização das SS (RUSHA - Rasse und Siedlungs Hauptamt), criado pelo ideólogo da "nobreza de sangue e terra" (e excriador de suínos) Walther Darré. A RUSHA tinha como função coordenar pesquisas sobre raças arianas estrangeiras que poderiam tornar-se elegíveis para uma "germanização futura", bem como promover (muito de acordo com sua orientação racista) casamentos eugênicos. E o principal foco desses experimentos era exatamente a guarda pretoriana do Führer. Para isso,

\footnotetext{
"uma das primeiras inovações do Departamento de Raça e Colonização foi a elaboração do código de casamento das SS, segundo o qual a aprovação oficial do matrimônio de um membro da organização ficava na dependência de prova de ascendência ariana da noiva - retroagindo pelo menos a 1750 - e de seu caráter, sanidade mental, saúde física e capacidade potencial de gerar filhos. O RUSHA mantinha ainda registros de linhagem de todos os membros das SS, e todos eles receberam um Sippenbuch (livro do clã), contendo o código matrimonial, no qual deveriam ser registradas as estatísticas da esposa e filhos" ${ }^{51}$.
}

\footnotetext{
${ }^{49}$ Enriquez, E. Da Horda ao Estado: Psicanálise do vínculo social, p. 295.

${ }^{50}$ Cores, P. J. A estratégia de Hitler: as raízes ocultas do nacional-socialismo, p. 122.

${ }^{51}$ Grunberger, R. A história das SS, p. 18.
} 
E essas exigências não se aplicavam, obviamente, apenas às noivas dos membros das SS. Os aspirantes da Guarda Negra (alusão à cor dos seus uniformes) deveriam pertencer à mais pura raça ariana (loiros de olhos claros, de preferência) demonstrando também, como suas futuras noivas, uma árvore genealógica sem "impureza judaica" remontando até 1750. Os jovens eram examinados minuciosamente por médicos que comprovavam seus traços étnicos e também pelo próprio Himmler, que analisava suas fotos com uma lupa para comprovar pessoalmente o grau de pureza de seus futuros subordinados. Dentre as provas mais "objetivas" estava a seleção por altura: para ingressar na SS-Verfügungstruppe (unidade de ataque) era necessário mais de 1,70 m e para o acesso à Leibstrandarte SS Adolf Hitler exigia-se altura superior a 1,84 m. A famosa SS-Totenkopfverbände (SS da Caveira), responsável pelos $\mathrm{KZ}$ (Konzentrationslager, ou campos de concentração) exigia soldados com altura superior a 1,71 m. Muito diferentes das exigências físicas eram as exigências intelectuais para ingressar no quadro das SS. Cerca de $40 \%$ dos recrutas eram apenas alfabetizados e as provas de acesso eram bem mais simples que aquelas exigidas na Wehrmacht (novo nome da Reichswehr). A educação que eles recebiam, como os estudos de etiqueta, serviam apenas para recobri-los com o verniz aristocrático necessário à constituição de uma nova casta de senhores. O resto da formação consistia em aulas de doutrinação política que passavam pela história do partido, pelo estudo das 25 teses elaboradas por Hitler e por reportagens do Völkische Beobachter, o jornal oficial do partido, onde as teorias raciais eram destiladas e os jovens recrutas eram convencidos de pertencerem à raça dos senhores. ${ }^{52}$

As SS representavam a filiação a uma elite selecionada e, como apontou Grunberger,

\footnotetext{
“na gíria do Partido, 'selecionado' encerrava a conotação de escolhido a dedo, bem como de puro-sangue - e desde que a raça formava o dogma-chave do credo nazista, não chegava a surpreender que alguns dos seus alto-sacerdotes tivessem feito sua aprendizagem na criação de animais. O líder agrícola nazista, Walter Darré, que aspirava transformar os agricultores alemães numa "nobreza de sangue e terra", fora outrora criador de suínos, enquanto Himmler (um entusiástico discípulo das teorias de
}

\footnotetext{
${ }^{52}$ Cores, P. J. A estratégia de Hitler: as raízes ocultas do nacional-socialismo, p. 126-128.
} 
Darré sobre a pureza racial humana) criava galinhas nos arredores de Munique antes de ser nomeado líder das SS",53.

Garantida a pureza racial de um membro das SS e comprovada a pureza das candidatas a noivas - cuja prole representaria a nova geração de arianos puros - o casamento eugênico poderia se realizar, mas não de qualquer forma. A união não poderia ser realizada em uma igreja comum, mas em um local adornado por símbolos rúnicos, suásticas e girassóis pertencente à própria SS. Himmler estimulava seus soldados a terem pelo menos quatro filhos e, assim como o casamento, o batismo também excluía a igreja: o bebê era abençoado por um oficial diante de um estandarte com a cruz gamada e um retrato de Hitler $^{54}$.

Na sua História da SS, Grunbergerer conta que mesmo depois da tomada do poder, quando o número de filiados subiu drasticamente, saltando de 52.000 para 165.000, Himmler ainda assim gostava de realizar pessoalmente a seleção dos recrutas. E essa preocupação com o mito ariano o teria levado a criar a Ahnenerbe ("Herança Ancestral"), "instituição destinada a investigar os restos pré-históricos nacionais de modo a estabelecer a continuidade racial dos alemães com seus antepassados", e que funcionava com dinheiro doado pelo círculo de amigos de Himmler entre os grandes empresários, patrocinando "escavações em grandes escalas em certos sítios na Alemanha, para não mencionar aventuras bizarras, como uma expedição ao Tibete". A imaginação de Himmler, prossegue Grunberger, o levou a impressionar-se profundamente com Henrique (“o passarinheiro”), rei alemão do século X, cujo aniversário de morte Himmler comemorava todos os anos, à meia-noite, na cripta da capital de Quedlinburg, onde repousariam os restos reais. Himmler afirmava entrar em comunhão com o monarca falecido, durante o sono, chegando finalmente a considerarse a reencarnação dele, identificação essa que o levou a jurar que continuaria a cruzada anti-eslava do rei morto ${ }^{55}$. E nessa história de peripécias medievais não poderiam faltar alusões ao Rei Artur, à Távola Redonda e ao castelo Wewelsburg:

\footnotetext{
"[Himmler] considerava também sua personalidade como bastante grande para pôr-se à sombra do Rei Artur, da Távola Redonda: mandou reformar com grandes despesas o arruinado castelo Wewelsburg, na Vestfália, e periodicamente reunia os doze mais
}

\footnotetext{
${ }^{53}$ Grunberer, Richard. A história da SS, p. 15. Grifo nosso.

${ }^{54}$ Cores, P. J. A estratégia de Hitler: as raízes ocultas do nacional-socialismo, p. 133.

${ }^{55}$ Grunberger, R. A história da SS, p. 39-40.
} 
graduados Obergruppenführer das SS em torno da mesa de carvalho de uma alta e abobadada sala de jantar. (Por ordens de Himmler, todos eles traziam um escudo de armas próprio e, durante a estada no castelo, ocupavam uma câmara mobiliada ao estilo da época e dedicada a um herói alemão específico). O mais sagrado dos lugares de Wewelsburg era um santuário subterrâneo" ${ }^{\text {" }}$.

A organização Ahnenerbe, responsável pelas pesquisas sobre as origens do povo ariano, financiava estudos e escavações arqueológicas com a finalidade de comprovar as origens biológicas do homem como partindo dos arianos, e cujo centro de difusão seria o Tibete. Enquanto isso, outra importante organização, a Sociedade Fonte de Vida, encarregava-se de estimular a natalidade entre arianos puros para que em 100 anos toda a população da Alemanha estivesse depurada de indivíduos indesejáveis, o que significa uma nação de arianos perfeitos. Para tanto, surgiu intimamente vinculada à Sociedade Fonte de Vida a Fundação Mutter und Kind (mãe e filho) de auxílio à natalidade, e junto com ela surgiram também as Lebensborn (casas de maternidade). Nesses lares, mulheres arianas dispostas a terem filhos eram estimuladas a copularem com a elite das SS, cujos descendentes de sangue puro governariam o mundo:

\footnotetext{
"Tudo isso era financiado pelas propriedades tomadas do povo judeu e, no que concerne às mães, podiam cuidar de seus filhos bastardos nos lares de maternidade ou então cedêlos ao Estado, que os entregava em adoção a famílias, cuidadosamente escolhidas, das SS. A castidade cristã ficava esquecida no passado, podendo-se considerar essa atitude egoísta em relação ao bem da nação. Não é de estranhar que os homossexuais passassem a fazer parte dos inimigos do Estado, sendo expulsos das SS entre 1934 e 1935, e colocados em campos de concentração, ao lado de judeus, ciganos, prostitutas, testemunhas de Jeová, inimigos políticos e outros, tendo a opção de obter a liberdade se emigrassem para bem longe do Terceiro Reich" ${ }^{\text {57 }}$.
}

O objetivo de tudo isso era muito obvio: acelerar o processo de arianização. $\mathrm{O}$ que incluía, nesse projeto, o seqüestro de crianças de características nórdicas dos povos dominados, que vieram a ser adotadas por famílias alemãs que não conseguiam ter filhos.

"No fim, milhares de crianças da Lebensborn foram colocadas nas casas de casais nazistas sem filhos; mais importante ainda, durante a guerra, o objetivo original - dar à

\footnotetext{
${ }^{56}$ Idem, ibidem, p. 40-41.

${ }^{57}$ Cores, P. J. A estratégia de Hitler: as raízes ocultas do nacional-socialismo, p. 142.
} 
luz e criar crianças alemãs ilegítimas - foi substituído pela espoliação genética da Europa oriental. Quando de sua viagem de inspeção à Polônia ocupada, Himmler ficara impressionado com a aparência nórdica de numerosas crianças eslavas. Isto pode ter dado início a uma cadeia de raciocínio que culminou com o objetivo, durante a guerra, de 'ampliar a existente base sanguínea da Alemanha de 90 para 120 milhões'. Crianças seqüestradas - arrancadas de orfanatos ou de supostas famílias da resistência - foram levadas para os lares da Lebensborn em toda a Europa ocupada" ${ }^{\circ 8}$.

Ao mesmo tempo, a sociedade Ahnenerbe, através da Volksdeutsche Mittelstelle (Oficina de União para os Alemães Étnicos) tentava agregar no mesmo solo todos os alemães do mundo. Não antes de submetê-los, claro, a desgastantes provas de pureza racial que precediam, necessariamente, o reassentamento.

Esse modelo de império pangermânico calcado na purificação da raça não era estranho aos quadros do ocultismo. A comunidade armanista de Guido Von List já preconizava um modelo de império calcado na hieranquia racial onde a raça heróica ario-germânica governaria sobre a casta de escravos não arianos. Os princípios políticos dessa nova ordem exigiriam a obediência estrita a leis raciais e matrimoniais onde as novas famílias deveriam manter registros genealógicos detalhados que atestassem sua pureza racial e somente os ario-germanos teriam direito à cidadania. E de acordo com o romantismo influente na época e o horror ao mundo moderno, List pregava o desenvolvimento de um novo feudalismo a partir da criação de grandes latifúndios. ${ }^{59}$ Essas idéias publicadas em 1911, décadas antes do nazismo, guardam muita semelhança com a política racial do III Reich (e o místico elitismo das SS), bem como com as concepções do ideólogo Walther Darré, criador da política agrária nazista, e que pregrava um "regresso à terra".

Assim como na violência, o componente irracional desse tipo (e de todo tipo) de misticismo nos remete a uma ação que se supõe racionalmente motivada quando na verdade é refém de afetos inconscientes que escapam inteiramente ao controle do sujeito. E é a partir dessa ignorância acerca de seu mundo psíquico que o sujeito constrói seus esquemas de ação racionalizando-os como um comportamento objetivamente motivado. Porém, se é verdade que essas "ilusões da consciência" têm um fundamento psicológico também é verdade que os clichês que servem de alimento à consciência que delira são fornecidos pela cultura.

\footnotetext{
${ }^{58}$ Grunberger, R. A história da SS, p. 67.

${ }^{59}$ Goodrick-Clarke, N. Las oscuras raices del nazismo, p. 91.
} 
Ao estudar o tema das ilusões da consciência no caso das neuroses e das psicoses, Freud postula que a diferença entre as duas reside no desfecho do embate entre o ego e a realidade. Tanto na neurose quanto na psicose, em um primeiro momento, o ego se afasta da realidade, e a diferença está no desfecho dessa dinâmica. No caso da neurose, um fragmento de realidade é evitado, mas a realidade como um todo não é repudiada, ela é apenas ignorada. No caso da psicose, a realidade não só é repudiada como se tenta substituí-la por uma outra realidade segundo os precipitados psíquicos de antigas relações com essa mesma realidade que se pretende remodelar. Esses precipitados são "os traços de memória, as idéias e os julgamentos anteriormente derivados da realidade e através dos quais a realidade foi representada na mente". O que a psicose faz é tentar conseguir novas percepções que correspondam a essa nova realidade por ela modificada, e isso se dá, claro, a partir da alucinação. Mas a força da realidade é intensa e o preço que o sujeito paga por essa tentativa de remodelamento através de delírios e alucinações é o caráter aflitivo, gerador de ansiedade, dessas tentativas $^{60}$.

A experiência do nazismo, porém, violou esse último preceito da argumentação de Freud: não foi gerada nem tanta aflição e nem tanta ansiedade. $\mathrm{O}$ erro, porém, não reside na lógica do argumento, mas no grau em que a realidade conseguiu ser objetivamente remodelada. Talvez em nenhum outro momento da história se tenha conseguido transformar a realidade a tal ponto que o delírio e a alucinação não representassem mais um remodelamento da realidade, mas um reflexo da realidade mesma. Porque quando o próprio real conseguiu se converter no conteúdo da alucinação, e esta passou a corresponder à realidade, a alucinação deixa de expressar a verdade apenas do mundo psíquico (e a mentira do mundo) para representar esse "mundo novo" absolutamente real, a alucinação converte-se em julgamento racional. Neutralizada a aflição e a ansiedade, pacificado o espírito, não sobra mais nada capaz de indicar ao sujeito a irracionalidade de seus pensamentos.

A questão é que Freud acredita na suposta evidência de que o indivíduo é capaz de distinguir as realidades de idéias e desejos, por mais intensos que estes sejam, mesmo que em muitos momentos a teoria diga outra coisa: "é de todo impossível sustentar que os desejos inconscientes devem necessariamente ser considerados como realidades tão $\operatorname{logo}$ se tenham tornado conscientes" ${ }^{\text {"1 }}$. O motivo disso é que Freud

\footnotetext{
${ }^{60}$ Freud, S. A perda da realidade na neurose e na psicose.

${ }^{61}$ Freud, S. Suplemento metapsicológico à teoria dos sonhos.
} 
considera justificável presumir que a crença na realidade vincula-se à percepção através dos sentidos, e argumenta que também aceitamos uma percepção como real quando um pensamento é conduzido pela regressão até os traços de memória inconscientes dos objetos, chegando depois à percepção, por isso a alucinação traria consigo a crença na realidade. Mas Freud refuta a hipótese de que a regressão seja a responsável pela alucinação considerando que, se fosse assim, "toda regressão com intensidade suficiente produziria alucinação com crença em sua realidade" (como é o caso de alguns sonhos), o que não acontece. A regressão deveria constituir-se de "algo mais que a revivescência regressiva de imagens mnêmicas que em si mesmas são Ics"

O tema não é em nada irrelevante, afinal, é de uma enorme importância prática que consigamos distinguir entre realidade e alucinação, "toda a nossa relação com o mundo externo, com a realidade", afirma Freud, "depende de nossa capacidade nesse sentido". Em seguida, ele resume a análise da transição dos processos primários aos processos secundários, segundo essa exigência imperativa:

\footnotetext{
"Formulamos a ficção de que nem sempre possuímos essa capacidade e de que, no começo de nossa vida mental, de fato alucinamos o objeto que nos satisfaria quando sentimos necessidade disso. Mas em tal situação a satisfação não ocorreu, e essa falha deve ter feito com que logo criássemos algum dispositivo com a ajuda do qual fosse possível distinguir tais percepções carregadas de desejo de uma real satisfação e evitálas no futuro. Em outras palavras, desistimos da satisfação alucinatória de nossos desejos ainda muito cedo e estabelecemos uma espécie de 'teste de realidade",63.
}

Como a alucinação consistiria em uma catexia do sistema Cs.(Pcpt) a partir do interior, uma condição necessária para a ocorrência da alucinação seria que a regressão fosse levada longe o suficiente até alcançar esse sistema, abolindo assim o teste de realidade. Então, como já apontamos antes, o organismo consegue distinguir externo de interno de acordo com a relação entre essas percepções e a ação muscular do organismo, "uma percepção que desaparece por meio de uma ação é reconhecida como realidade"64. Por isso é problemático para o indivíduo lidar com aquilo que provém do interior, contra as reivindicações dos seus instintos e daí a tentativa constante do indivíduo de projetar para o exterior aquilo que se torna problemático dentro dele. A função de

\footnotetext{
${ }^{62}$ Idem, Ibidem.

${ }^{63}$ Idem, Ibidem.

${ }^{64}$ Idem, Ibidem.
} 
orientar o indivíduo nesta tarefa deve-se ao sistema Cs.(Pcpt), que tem à sua disposição as inervações motoras capazes de realizar o teste de realidade.

Por mais que Freud note que nossa ação sobre o mundo serve para adequá-lo aos nossos desejos, não era possível imaginar que um pensamento delirante ou uma alucinação tivessem força suficiente para, através da "ação muscular do organismo" perverter a realidade ao ponto de convertê-la totalmente (o que é típico dos totalitarismos) naquilo que a partir daí serviria como "teste de realidade" para as "percepções carregadas de desejo".

Convém distinguirmos mais claramente a diferença entre erro e ilusão. Uma ilusão não é a mesma coisa que um erro ou é necessariamente um erro. Um erro seria a crença de que o sol é do tamanho que se apresenta à nossa percepção ou que ele gira em torno da Terra porque o vemos deslocar-se no céu ao longo do dia. Um exemplo de ilusão seria a crença nazista na superioridade da raça germânica. Ou seja, uma ilusão não precisa ser necessariamente falsa (algumas ilusões podem se mostrar verdadeiras) ou estar em contradição com a realidade para que possamos considerá-la uma ilusão. Para tal é necessário que a motivação que a gerou tenha sido a realização de um desejo, e é por isso que "desprezamos suas relações com a realidade, tal como a própria ilusão não dá valor à verificação". E algumas desas crenças, aponta Freud, "são tão improváveis, tão incompatíveis com tudo que laboriosamente descobrimos sobre a realidade do mundo, que podemos compara-las - se considerarmos de forma apropriada as diferenças psicológicas - a delírios". ${ }^{65}$ Freud coloca aí o remodelamento delirante da realidade como o modo mais deseperado de fugir do desprazer.

O caso de Daniel Paul Schreber, o juiz-presidente da corte de apelação da cidade de Dresden, cujas célebres memórias Freud analisara é muito significativo, não apenas por tratar-se de um caso de paranóia, mas porque surgem nessas memórias muitos elementos de ocultismo (como fantasias de destruição de mundos, elucubrações acerca da história da humanidade e fantasias "cosmológicas") bastante semelhantes àqueles de Blavatsky, Horbiger, Clever Symnes (o apologista da Terra oca), Guido von List, Lanz von Liebenfels e Karl Maria Wiligut, só para citar os mais importantes.

Em determinado momento de seus delírios e alucinações, Schreber acredita que o universo inteiro estava em dificuldades. Determinada constelação precisaria ser "abandonada", o planeta Vênus fora "inundado", Cassiopéia deveria ser condensada

\footnotetext{
${ }^{65}$ Freud, S. O futuro de uma ilusão.
} 
(por motivos ignorados) em um único sol, mas as Plêiades ainda poderiam ser "salvas". No espaço de uma noite, séculos haveriam passado e profundas transformações teriam ocorrido tanto com a Terra quanto com o resto do sistema solar. O tempo de duração do período de povoamento da Terra, de 14.000 anos suposto por Schreber se esgotara no lapso de tempo de alguns meses (na percepção dele) e restaria ao planeta apenas alguns poucos anos, cerca de 212 (que ele julgava já ter transcorrido). Fora do sanatório, talvez só tivesse restado ele, Schreber, e poucas figuras humanas um tanto bizarras que ele entendia como "homens feitos às pressas", produzidos talvez por milagre, ou mesmo que a cidade de Leipzig tivesse sido arrancada do planeta Terra e instalada em algum outro corpo celeste. O céu estrelado, em sua totalidade ou a maior parte dele havia sido extinto. O fim do mundo dever-se-ia, de acordo com algumas de suas visões, a "uma diminuição do calor do Sol, causada por um afastamento do Sol e uma glaciação mais ou menos geral daí resultante". ${ }^{6}$

Freud argumenta, com muita propriedade, e tendo em mente sua teoria da catexia libidinal que a catástrofe do fim do mundo presente nos delírios de Schreber representava uma retirada da catexia libidinal do mundo externo em geral, consistido os delírios em uma racionalização secundária da situação de um mundo agora irrelevante e indiferente para ele. O fim do mundo figuraria então como a projeção da catástrofe interna do mundo de Schereber. Assim o paranóico reconstrói o mundo, não melhor do que era antes, mas de uma forma capaz de ainda viver nele, e com o trabalho de seu delírio. Sendo assim, nota Freud, "a formação delirante, que presumimos ser o produto patológico, é, na realidade, uma tentativa de restabelecimento, um processo de reconstrução". Ou seja, seu ego era mantido enquanto o mundo era sacrificado. ${ }^{67}$

Mas, dependendo da cultura, uma ilusão pode ser alçada ao status de verdade e seus pregadores à categoria de profetas. O mesmo delírio milenarista calcado na destruição das raças, na onipotência do pensamento, nas angústias persecutórias, nas visões místicas, enfim, a paranóia coletiva e as projeções que conduziram o mago Wiligut a uma internação forçada em um hospício fizeram dele, anos depois, o sábio iluminado que ganharia a confiança de Himmler. E de Blavatsky uma profeta do ocultismo. A diferença entre Schereber e Hitler ou Himmler é que estes contavam com os meios necessários para reconstruir o mundo real à imagem de suas subjetividades

\footnotetext{
${ }^{66}$ Schreber, Daniel Paul. Memórias de um doente dos nervos, p. 78-91

${ }^{67}$ Freud, S. Notas psicanalíticas sobre um relato autobiográfico de um caso de Paranóia (Dementia Paranoides).
} 
corrompidas. Para que seus egos fossem mantidos, o mundo precisava perecer através desse processo de "reconstrução" patológico.

Como o resto dos alemães puderam ser arrastados por esse processo, Freud nos deu a indicação em seus estudos de Psicologia de Grupos, que aponta como a essência de um grupo os laços libinais que unem seus membros entre si e a seu líder. Em resumo, para Freud a fórmula para a constituição libidinal dos grupos que têm um líder é a seguinte: um grupo é um certo número de indivíduos que colocaram um só e mesmo objeto no lugar de seu Ideal de Ego (que Freud posteriormente irá denominar "superego") e, consequentemente, identificaram-se uns com os outros em seu Ego. Isso explica a subordinação e a desindividualização daí decorrente entre os indivíduos em um grupo: por um lado vinculados entre si, e por outro maciçamente identificados com o líder ou com o ideal do grupo, o Ego fica inevitavelmente enfraquecido ${ }^{68}$.

Hanna Segal, refletindo sobre a guerra com o auxílio das teorizações de Freud, nos lembra que os grupos geralmente são narcisistas, auto-idealizadores e paranóides com relação aos outros grupos (o "narcismo das pequenas diferenças" a que alude Freud), e argumenta que eles "estabelecem e controlam fantasias e ansiedades psicóticas". O conflito intra-grupo bem como a culpa pela agressão sentida podem ser atenuados através da projeção em um grupo externo e em nossas vidas particulares lidamos constantemente com um superego que controla a agressividade, porém,

"se investirmos o superego individual num superego conjunto de grupo, podemos, aparentemente sem culpa, perpetrar horrores que não poderíamos suportar na nossa existência individual. Quando tais mecanismo fogem ao controle, os grupos, em lugar de controlarem o funcionamento psicótico, colocam-no em prática, e temos comportamentos irracionais tais como guerras e genocídios"

Outra ilusão do nazismo foi a sua antropologia racial que rapidamente ligou-se ao anti-semitismo. As idealizações dos alemães, como sabemos, foram frustradas a partir da dura realidade de que a unificação de 1871 sob a liderança da Prússia e com o empenho de Bismarck não mudara em nada o cotidiano da imensa maioria dos alemães que após a tão esperada unificação continuaram sofrendo como camponeses ou como proletários nos grandes centros urbanos enquanto os junker, grandes proprietários de terras, começavam a notar o enriquecimento dos judeus que lucravam mesmo sem

\footnotetext{
${ }^{68}$ Freud, S. Psicologia de Grupo e análise do Ego.

${ }^{69}$ Segal, Hanna. O silêncio é o verdadeiro crime. In: Costa, Gley P. (org.). Guerra e Morte, p. 207-208.
} 
serem proprietários de terras, respondeno a isso com um anti-capitalismo que encontrava vazão no anti-semitismo. Daí ao fato de responsabilizar os judeus pela decepção que se seguiu à unificação o caminho foi curto e a população tirou rapidamente suas conclusões. Com a eclosão da Primeira Guerra Mundial em 1914, a derrota militar que se seguiu acabou forçando Guilherme II a abdicar em novembro de 1918. Surge então um regime parlamentar democrático mas apoiado sem grande convicção por muitos alemães que viam na aceitação da democracia apenas uma forma de conseguir a indulgência dos países vencedores. Com o desesprezo dos alemães pela política estava aberta a entrada dos judeus na vida política, coisa que se revelou uma grande catástrofe quando, a partir dessa visibilidade, eles surgiram como beneficiários da vitória dos aliados, sendo considerados, posteriormente, os responsáveis pela derrota alemã na guerra. Não bastasse isso, como conseqüência das agitações geradas pela derrota, a república, já no início de 1919 foi abalada por uma tentativa de golpe de esquerda, liderados pelos revolucionários judeus Rosa Luxemburgo, Kurt Eisner e Gustav Landauer. Isso fez com que a burguesia se alinhasse com a extrema direita contra algo que foi sentido como uma grande ameça contra a Alemanha. A conclusão mais óbvia foi a de que a revolução havia sido promovida pelos judeus ${ }^{70}$. Os movimentos ocultistas que analisamos, também influenciados por essa dinâmica, forneceram por seu lado uma contribuição bastante original para o agravamento da situação com suas justificativas calcadas no esoterismo.

O anti-semitismo expressa o desespero de grande parte dos alemães e sua tentativa de encontrarem, projetivamente, um culpado pelas suas desgraças. Como sabemos, em termos psicanalíticos, a projeção representa um mecanismo de defesa em que o ego, para se livrar de representações desagradáveis, acaba por transpô-los para o exterior. Aquilo que se projeta são sentimentos e desejos que o sujeito não aceita em si mesmo. Mas Freud não encara a projeção como um mecanismo patológico, já que ela estaria presente em todos os indivíduos normais, cumprindo uma função de autopreservação, pois é a tendência projetiva que auxilia o ego a traçar os limites entre interior e exterior, cumprindo assim uma importante função epistemológica. Essa seria a função positiva da projeção. Em sua forma mórbida, pode-se recair na fobia ou na paranóia. Nestes últimos casos, o que vemos é um remodelamento delirante da realidade.

\footnotetext{
${ }^{70}$ Sorlin, Pierre. O anti-semitismo Alemão, p. 58-60.
} 
Não há nada mais representativo, na história do nazismo, da relação entre projeção patológica e paranóia que a lenda criada em torno do fantástico documento que ficou conhecido como "Os Protocolo dos Sábios de Sião". O documento consistia na ata de uma suposta reunião secreta de Judeus e Maçons ocorrida na Basiléia, em 1807, e que teria como objetivo arquitetar um plano de ação visando uma "dominação mundial" sob o controle dos judeus. Em determinado momento o texto dizia o seguinte:

\footnotetext{
“Se, no momento atual, já soubermos apoderar-nos dos espíritos das sociedades cristãs de tal modo que todos olham os acontecimentos mundiais através dos vidros de cor dos óculos que lhes pusemos aos olhos, se já, em nenhum Estado, não há mais fechaduras que nos impeça o acesso de que os cristãos tolamente denominam segredos do Estado, que será quando formos os donos reconhecidos do universo sob o domínio de nosso rei universal?",71
}

Esse texto lendário (ao qual Hitler já se refere no Meim Kampf) serviu (e ainda serve) de "prova" da conspiração judaica mundial. O texto já foi submetido a várias análises e parece não restar dúvidas de que se trata de uma fraude baseada em sátiras políticas, sobretudo nas expostas em um livro de Maurice Joly (“O diálogo no inferno entre Maquiavel e Montesquieu”), publicado em 1856 e que não tratava da questão judaica. Hitler, ao citá-lo em sua autobiografia faz um péssimo uso da negação em psicanálise, argumentando que as críticas correntes, ao afirmarem que "Os Protocolos" constituiriam uma fraude - pasmem - apresentavam a melhor prova de que eles seriam verdadeiros. ${ }^{72}$ A paranóia dos anti-semitas precisava desse documento para justificar seu anti-semitismo, e seu conteúdo, que apontava para uma tentativa dos judeus dominarem o mundo nada mais era que a projeção dos desejos de domínio global dos próprios anti-semitas alemães.

Adorno e Horkheimer reconhecem a dinâmica pulsional da projeção, que segue os ditames do psiquismo, mas eles apontam, com muita propriedade, no exterior, os clichês que dão forma ao conteúdo do delírio: "Os impulsos que o sujeito não admite como seus e que, no entanto, lhe pertencem são atribuídos ao objeto: a vítima em potencial. Para o paranóico usual, sua escolha não é livre, mas obedece às leis de sua doença" ${ }^{, 73}$. No fascismo, apontam os autores, o comportamento paranóico é adotado pela

\footnotetext{
${ }^{71}$ Anônimo, Os Protocolos dos Sábios de Sião, p. 23.

${ }^{72}$ Hitler, A. Minha Luta, p. 228.

${ }^{73}$ Adorno; Horkheimer. Dialética do esclarecimento, p. 174.
} 
política que transforma em realidade concreta o objeto da doença, tornando o sistema alucinatório a norma racional do mundo. A percepção do mundo se dá, em certo sentido, através da projeção, mas entre "o interior e o exterior, abre-se um abismo que o sujeito tem de vencer por sua própria conta e risco". Em outros termos, o sujeito, para refletir, precisa devolver ao objeto mais que aquilo que dele recebe, recriando assim um mundo exterior com as impressões que o mundo deixa, constantemente, em seus órgãos dos sentidos. Quando esse entrelaçamento se rompe, o ego se petrifica, cessando qualquer possibilidade de reflexão.

“O patológico no anti-semitismo não é o comportamento projetivo enquanto tal, mas a ausência da reflexão que o caracteriza. Não conseguindo mais devolver ao objeto o que dele recebeu, o sujeito não se torna mais rico, porém, mais pobre. Ele perde a reflexo nas duas direções: como não reflete mais o objeto, ele não reflete mais sobre si e perde assim a capacidade de diferenciar. Ao ouvi a voz da consciência moral, ele ouve vozes" ${ }^{, 74}$.

Assim, Adorno e Horkheimer traçam a distinção entre projeção normal e projeção patológica. Na projeção normal, o sujeito é capaz de perceber a diferença entre a sua contribuição ao objeto e a realidade do objeto percebido. No caso da falsa projeção, não existe reflexão, o que há é a subjetividade do sujeito transporta para o real, convertendo o mundo no palco dos seus delírios.

A atribuição de sentido ao mundo, que passa pela projeção, depende tanto do objeto quanto do sujeito que reflete esse objeto, atribuindo-lhe um sentido. Aquilo que os movimentos ocultistas fazem é atribuir ao mundo um sentido totalmente arbitrário, da mesma forma que o paranóico atribui ao seu mundo interior. Mas um esquema privado como o do paranóico, que não é partilhado por ninguém, é o que torna louco todo o processo.

Reflexo da subjetivação do sentido, o ocultismo apresentar-se-ia como o complemento da reificação, e as práticas mágicas que o inspiram como a tentativa desesperada de arrancar do real algum sentido:

“Os movimentos ocultistas modernos da envergadura da astrologia são formas de uma superstição de épocas desaparecidas há muito tempo e mais ou menos artificialmente ressuscitadas; a receptividade correspondente se mantém viva até hoje

\footnotetext{
${ }^{74}$ Idem, Ibidem, p. 176.
} 
por razões sociais e psicológicas, porém tais conteúdos requentados são incompatíveis com o nível alcançado pela instrução universal" ${ }^{\text {,75 }}$.

A regressão da consciência operada pela cultura, que afasta do sujeito sua possibilidade de autodeterminação, lesa a imaginação transformando a realidade em algo de fantástico e a ilusão em realidade. O ocultismo não é só irracional, por mais que os ocultistas se ufanem muito disso; o ocultismo também compartilha com o fascismo os mesmos esquemas de pensamento, do tipo do anti-semitismo ${ }^{76}$.

Porém, a idéia de uma casta superior de eleitos, representantes da verdadeira humanidade contraposta a todo o resto entendido como a "ralé", e que também responde a essas categorias explicativas, não é uma idéia nova. Não queremos aqui reduzir o fenômeno da formação de castas à psicologia individual, mas nesse sentido uma contribuição em especial nos pareceu bastante fecunda para a compreensão das teorias raciais que descrevemos.

Franco Fornari, ao analisar os sonhos de mulheres grávidas, constata que a expectativa-premonição da criança nas fantasias inconscientes dessas mulheres aponta tanto para a idealização, para o superinvestimento narcisicamente orientado do produto da concepção (a criança como salvador-messias) quanto para a criança como um objeto perseguidor. Fornari chama essa angústia de "angústia genética", definindo-a como a angústia da deterioração do produto da concepção, que se expressa na fantasia dessas mulheres, como o medo de dar à luz uma criança defeituosa, doente, monstruosa. Tal angústia, porém, não é totalmente descabida, já que existe mesmo a possibilidade real, fruto do acaso genético, de que isso de fato aconteça. Nesses termos, Fornari entende a "premonição da criança messias” de Bion, próprio do suposto básico de acasalamento, como uma "fantasia de idealização da criança que constituiria um mecanismo de defesa contra a angústia genética", ou seja, a criança idealizada ajuda a exorcizar o medo de que a criança que irá nascer seja um objeto perseguidor, fruto dos "ataques" da mãe (no sentido kleiniano), que poderia tê-lo "estragado". O suposto básico de acasalamento elaborado por Bion exprimiria sob a forma de um mecanismo de defesa (e no nível do comportamento coletivo no estado embrionário), a elaboração dessa angústia "sob a

\footnotetext{
${ }^{75}$ Adorno, T. Filosofia y superstición, p. 109.

${ }^{76}$ Adorno, T. Mínima moralia, p. 210.
} 
forma de idealização do produto do acasalamento como nova segurança contra angústias persecutórias e depressivas centradas na criança"77.

Mas para que a ilusão seja mantida, como bem notou Bion, é preciso evitar o teste de realidade, ou seja, o suposto básico de que a criança é o messias jamais deve se realizar, a criança não deve nascer. E o Messias, como aponta Bion, não precisa ser necessariamente uma pessoa, pode ser uma idéia, ou uma utopia que salvará o grupo "dos sentimentos de ódio, destruição e desespero do próprio grupo ou de outro grupo, mas para que isso aconteça a esperança messiânica, obviamente, jamais deve ser realizada. Somente restando uma esperança, a esperança efetivamente persiste" ${ }^{78}$ No caso que estamos tratando, digamos logo, o princípio sagrado, o valor supremo em questão, enfim, a esperança messiânica era um mito: o mito do Estado racial.

Contudo, convém considerarmos uma questão muito apropriadamente levantada por Enriquez acerca da semelhança entre judeus e alemães no que diz respeito ao seu "messianismo":

\begin{abstract}
"Curiosamente [alemães e judeus] são, também, povos profundamente semelhantes. Povos messiânicos, ambos sentem ter um projeto a realizar, querem estar na terra para construir comunidades sólidas e mesmo fusionais (comunidades, de um lado com o Estado, do outro sem o Estado, mas ambas agrupando seres profundamente identificados ao ideal comunitário). Povos, portanto, capazes de seguir os profetas ou os messias que lhes designarão as novas terras prometidas. O discurso paranóico ou megalomaníaco não lhe causa medo. Muito pelo contrário!"79
\end{abstract}

Mas retornemos a Fornari. Essas idéias de Bion levam Fornari a se ocupar do caráter sagrado dessa idealização, entendida como "suma esperança positiva acompanhada de um mínimo de verificabilidade no plano da realidade, porque o teste de realidade impediria a manutenção da idealização" ${ }^{\text {. }}$. A aristocracia, por sua vez, seria entendida como um mecanismo de defesa contra as angústias persecutórias e depressivas ligadas ao produto da concepção. Fornari não deixa de notar a existência de mecanismos culturais sócio-econômicos orientando a divisão da sociedade em classes sociais (sendo a hereditariedade dos bens familiares o mais importante), mas pensa que esses mecanismos devem ser entendidos paralelamente à hipótese da fundação

\footnotetext{
${ }^{77}$ Fornari, F. Por uma psicanálise das instituições, p. 118.

${ }^{78}$ Bion, W. R. Dinâmica do grupo: uma revisão, p. 172

${ }^{79}$ Enriquez, E. Da Horda ao Estado: Psicanálise do vínculo social, p. 333.

${ }^{80}$ Fornari, F. Por uma psicanálise das instituições, p. 119.
} 
"genético-sexual" dessas classes, e ele articula essas duas explicações supondo que a angústia genética poderia ser controlada a partir de mecanismos de defesa de natureza econômica. No caso, o prejuízo genético (fantasiado ou real) sofrido pelo filho poderia ser reparado graças à transmissão hereditária do patrimônio.

Para exemplificar sua hipótese, Fornari lembra que no nível do "grupo racional", o melhor produto seria fruto do casamento híbrido, sendo assim, por que a aristocracia e as classes dominantes em geral privilegiariam o casamento endogâmico? Parte da explicação já foi fornecida acima. Uma outra explicação, Fornari indica analisando o sistema de castas dos brâmanes, fundado na hierarquia, e que supõe o produto da concepção no interior da casta como absolutamente positivo, mas que, sendo um caso de crença, logo preso à referência do sagrado (que, como vimos, opera com o máximo de presença positiva com um mínimo de verificabilidade), isso impede a verificação de casos negativos derivados do acasalamento no interior da casta. E "os mecanismos do casamento endogâmico, assim como a concentração econômica e os mecanismos culturais clássicos favorecidos na casta privilegiada" serviriam a esse objetivo. Um outro mecanismo utilizado para impedir a verificação dessa ilusória positividade absoluta do acasalamento endogâmico (e o mais típico, podemos dizer) seria "o isolamento e a separação rituais entre as diferentes castas”, já que na sociedade de castas hindu, o acasalamento exogâmico é punível com a exclusão da casta. Assim,

\footnotetext{
“A interdição do acasalamento exogâmico sentido como impuro e contaminante teria, pois, como objetivo principal, no plano do mágico e do ilusório, manter o impuro fora da própria casta e, ao mesmo tempo, impedir que se verifique que o acasalamento exogâmico não é, absolutamente, portador de deterioração do produto da concepção" ${ }^{\text {. }}$.
}

Esse mecanismo de separação entre as castas pressupõe um mecanismo de clivagem que separa o grupo privilegiado (visto como bom, puro e positivo) dos demais grupos (vistos como maus, impuros e negativos). Alem da cisão, a identificação projetiva que coloca no produto da concepção do outro grupo os aspectos maus e deteriorados do próprio grupo privilegiado constitui-se no principal mecanismo produtor da casta impura. Porém, sempre existe a possibilidade do grupo que se converteu em bode expiatório não aceitar passivamente o papel de receptáculo do negativo, o que exige que ele seja controlado de forma sádico-onipotente pelas castas

\footnotetext{
${ }^{81}$ Idem, ibidem, p. 124.
} 
superiores que temem a reação das castas inferiores. Se essa dinâmica é aceita, o grupo dominado interioriza o conflito, e a culpa gerada pelo processo converte-se em autoagressividade e negação de si. Não deve causar espanto que, por conta mesmo desse jogo de projeções e identificações a própria casta inferiorizada fantasie o acasalamento exogâmico como um tipo de incesto a ser evitado, tendo em conta que os membros das castas superiores simbolizam os pais contra os quais não se pode rebelar.

$\mathrm{Na}$ Alemanha essa "angústia genética" tomou proporções as mais bizarras. Como vimos, o místico Rudolf Gorsleben, membro da sociedade Thule e estudioso das Eddas como fonte da religião ariana acreditava que a mulher poderia ser "impregnada", ocorrendo ou não concepção, pelo primeiro coito. Ou seja, se uma mulher ariana copulasse com um judeu, mesmo se isso não resultasse em gravidez a mulher estaria fadada a transmitir à sua descendência as características (degeneradas) desse seu primeiro amante. Não é difícil supor que o discurso de Hitler no Mein Kampf sobre o judeuzinho de cabelos negros que macula com seu sangue uma inocente menina ariana fosse também uma referência a essa concepção popular bastante difundida naquela época.

Nem mesmo a teoria da "continuidade do plasma germinativo" de Weismann que forneceu as metáforas científicas para as idéias de "sangue", "raça" e "corpo do povo" conseguiu diluir na cultura popular a idéia de "procriação à distância" conhecida como telegonia. De acordo com essa concepção, retomada pelos criadores de gado, a impregnação nada mais representava que o mecanismo da poluição racial. A telegonia será amplamente difundida a partir de 1917 com um romance de Arthur Dinther, intitulado O Pecado contra o Sangue, onde o herói racista Hermann Kämpfer vai descobrindo progressivamente a verdade do envenenamento racial (causado pelos judeus) enquanto desenvolve a teoria da "impregnação". 82

Pois bem, o conjunto de idéias místicas ou pseudo-científicas que motivaram o movimento nacional-socialista apontam para a perda da importância social dessas "castas superiores", mais especificamente da aristocracia de sangue. Georg Lukács aponta que a ideologia da burguesia nascente lutava pela igualdade de todos os homens, pelo menos no plano jurídico-formal, criticando os privilégios feudais existentes e as desigualdades estamentais remanescentes do feudalismo. Com o recrudescimento desse processo, em que a burguesia lutava por seus próprios interesses de classe, a dominação

\footnotetext{
${ }^{82}$ Conte, E; Essner, C. A demanda da raça: uma antropologia do nazismo, p. 122.
} 
da nobreza sofreu um duro golpe, tanto no plano político quanto no econômico, perdendo assim as funções sociais que possuíam na idade média e adquirindo por conta disso um caráter cada vez mais parasitário. Com isso, surgiu a necessidade de defender ideologicamente seus privilégios e é daí que surgem as teorias do racismo. Os ideólogos da nobreza passam a defender, contra os ideólogos burgueses, as desigualdades entre os homens como a expressão jurídica da desigualdade que a própria natureza estabelece entre os homens e as raças, e por essa razão nenhuma instituição poderia ir de encontro a essa verdade sem se chocar com os mais altos valores da humanidade ${ }^{83}$.

Hannah Arendt nota que essas doutrinas evolucionistas aliavam o conceito de hereditariedade ao de realizações pessoais (de caráter individual) muito caros ao amorpróprio das classes médias do século XIX, que queriam que os cientistas provassem serem os "grandes homens", e não os aristocratas, os representantes do "gênio da raça". Por isso era significativo que o pensamento racial (tanto na Inglaterra quanto na Alemanha) tivesse se originado "entre os escritores da classe média e não entre a nobreza, que tenha nascido do desejo de estender os benefícios dos padrões de nobreza a todas as classes, e que se nutrisse de sentimentos verdadeiramente nacionais". ${ }^{84} \mathrm{E}$ sobre Gobineau, ela argumenta que aquilo que ele realmente procurara na política teria sido “a definição e a criação de uma 'elite', que substituísse a aristocracia”. Logo,

\footnotetext{
“Em lugar de príncipes, propunha uma 'raça de príncipes', os arianos, que, segundo dizia, corriam o risco de serem engolfados, através do sistema democrático, pelas classes não-arianas inferiores. O conceito de raça tornava possível organizar as 'personalidades inatas' do romantismo alemão e defini-las como membros de uma aristocracia natural, destinada a dominar todos os outros" ${ }^{\prime 25}$
}

Ora, como nota T. W. Adorno, "seria má psicologia supor que aquilo de que se é excluído desperta tão somente ódio e ressentimento; também desperta uma espécie de amor possessivo e intolerante" ${ }^{\prime 86}$. Grunberger, historiador do nazismo, aponta que, na época, 1 em cada 134 alemães utilizava o aristocrático prefico "von" no nome, e a proporção de sangue nobre era ainda maior entre os SS Obergruppenführer (generais de quatro estrelas), de 1 em 5. Entre os SS Gruppenführer (tenentes-generais) a proporção

\footnotetext{
${ }^{83}$ Lukács, G. El asalto a la razón, p. 539.

${ }^{84}$ Arendt, Hannah. Origens do Totalitarismo, p. 210-211.

${ }^{85}$ Idem, Ibidem, p. 203.

${ }^{86}$ Adorno, T. W. Mínima Moralia, p. 45.
} 
era de 1 em 10 e entre os SS Brigadeführer (majores-generais) era de 1 em $7 .^{87}$ Essa interesse por heráldica e árvores genealógicas, típica da pregação ocultista da época, apontava, no caso da psicologia daqueles que se uniam a esses grupos, não apenas a busca de uma identidade cultural, mas como acontecera com o movimento romântico, significava a tentativa de reencontrar em um passado distante e medieval um mundo onde as relações fossem a negação completa do mundo moderno, mundo onde as relações não apresentavam ainda a fluidez típica da modernidade e que por isso, na imaginação desses indivíduos, sobretudo aristocratas cujos privilégios vinham decrescendo por conta das transformações culturais, apresentava-se como mais estável e seguro. Mas esse não era apenas o imaginário da aristocracia.

A assertiva de Adorno nos remete para esse encantamento pela aristocracia, que explica a ambigüidade da burguesia para com os valores da nobreza e a busca frenética de antepassados nobres por boa parte dos burgueses. Os exemplos de Lanz von Liebenfels (descendente da burguesia vienense) e Guido von List (filho de comerciantes de classe média) são exemplos muito representativos. Contudo, os sonhos aristocráticos não eram apenas uma prerrogativa da burguesia, como mostram as peripécias de Adam Alfred Rudolf Glauer, filho de um operário ferroviário, para ser reconhecido sob o sobrenome "von Sebottendorff". Porém, como toda a nobreza acredita estar ligada, em sua origem, a seus próprios deuses, era necessário não só buscar uma genealogia ainda mais remota (e por isso mais fantasiosa), bem como explicar a origem de todos os outros homens, ou seja, da "massa". Em outros termos, os senhores precisavam dar conta da origem dos escravos, bem como justificar ideologicamente essa divisão de forma sagrada (e portanto definitiva), como ocorre na divisão por castas.

Por isso Blavatsky rejeita o darwinismo, que propõe a ligação de todos os homens a um ancestral comum que não eram nem os deuses do hinduísmo e nem aqueles da mitologia nórdica. Pior: não se tratava sequer de um ancestral humano. Lanz, seguindo a trilha aberta por Blavatsky em seus delírios paleontológicos e antropológicos, aponta que a linhagem dos "seres inferiores" seria fruto do "bestialismo" cometido pelos arianos. No lugar de um ancestral comum, havia duas linhagens: a raça dos deuses (de quem descendiam, obviamente, os arianos) e a raça dos homens-bestas. Todo o falatório ocultista de Guido von List acerca de "princípios opostos" e a idéia de "energia primária" contida nos opostos e capaz de criar uma

\footnotetext{
${ }^{87}$ Grunberger, R. A história da SS, p. 47
} 
descendência perfeita é a racionalização do argumento que virá a seguir: a importância da eugenia para a superioridade ariana. A alusão à Germânia de Tácito serve de fundamento para suas aspirações aristocráticas quando ele vê ali estamentos sociais ário-germânicos encabeçados pela casta dos reis-sacerdotes, ou "Armanen" (daí Armanenschaft), os herdeiros do sol. As alusões constantes desses ocultistas a continentes perdidos como Agarthi ou Thule são tentativas de localizar o "paraíso perdido" de seus ancestrais divinos antes da degeneração da raça, paraíso esse dividido em estamentos sociais semelhantes àqueles do mundo medieval. A mitologia criada por Wiligut, o mago pessoal de Himmler, não difere muito disso. Seus ancestrais, os AdlerWiligoten, remontavam a 78.000 a. C., e os continentes desaparecidos fazem parte da história de seus antepassados, pertencentes à linhagem dos Asen (deuses do ar) e dos Wanen (deuses da água). O seu amigo Tarnhari, como sabemos, descendia da lendária tribo dos Wölsungen, a tribo preferida dos deuses, de acordo com a mitologia de Richard Wagner.

\section{Ciência, misticismo e modernidade}

Aprendemos que a renascença foi uma época revolucionária - prefigurada pela expansão ultramarina e pelo desenvolvimento comercial - e que representou uma reação contra o dogmatismo medieval, cuja filosofia e ciência baseavam-se em Aristóteles. Aprendemos também que foi na renascença que se decretou o divórcio entre fé e razão, onde se redescobriu a antiguidade clássica e, na ciência, vimos Nicolau Copérnico (1473-1543) refutar o sistema geocêntrico - herança do período medieval, alicerçado sobre Ptolomeu e as escrituras - em nome do sistema heliocêntrico. De fato, a renascença enriqueceu o corpo das ciências preparando o terreno para a revolução científica do século XVII, de Galileu e Descartes. Entendemos a renascença, porém, como o momento em que a luz da razão - antecipando o iluminismo e a revolução científica - começa a dissolver a escuridão medieval, deixando no passado o misticismo e as superstições. Nada mais falso que isso.

Em nome do humanismo, vemos no renascimento uma crítica à astrologia que não é, de fato, científica. Se por um lado a astrologia prescinde de explicações sobrenaturais ao ligar o destino humano aos movimentos dos astros (explicando os fenômenos naturais a partir de causas naturais), ela se choca com o ideal humanista que 
vê o homem como o artífice de seu próprio destino. É então por isso que Pico della Mirandola (1463-1494) escreve sua crítica contra a astrologia. Tal exemplo, que parece confirmar a idéia do renascimento como uma revolução contra o misticismo, precisa ser analisado com mais cuidado. Pico della Mirandola combate a astrologia a partir de uma concepção de homem que é refratária às explicações astrológicas, apenas isso. E o mais importante: ele é o principal responsável, no interior do renascimento, pela síntese entre o cabalismo judeu e o cabalismo cristão.

No século XVI, Martin Lutero (1483-1546) abala decisivamente o poder do papado inciando o processo de secularização tão característico da modernidade, mas por outro lado, com sua doutrina do "servo arbítrio" e da salvação exclusivamente pela fé que prescinde das obras, ele transforma o homem em escravo do pecado negando sua autonomia diante de Deus enquanto afirma sua liberdade religiosa. O "misticismo anárquico" que caracteriza a absoluta liberdade espiritual-religiosa do critão contrasta com sua concepção na natureza humana pecadora que o conduz a submeter, no plano terreno, o homem aos poderes seculares e às autoridades constituídas, ou seja, boas ou más as leis devem ser obedecidas com resignação. Ele faz a apologia do poder dos príncipes sobre os seus súditos enquanto os deixa livres para agirem de acordo apenas com sua consciência inspirada misticamente por Deus, tornando legítima a guerra e a repressão da revolta dos camponeses (movida pela ânsia de recompensas mundanas) pelos soberanos. A idéia, bastante simples e característica de todo o absolutismo era a de que os mais fortes, os escolhidos, tinham o direito de exercer seu poder porque Deus os havia escolhido e por isso eles eram os mais fortes. Aos demais, escravos do pecado, precisamente por serem escravos do pecado não foram eleitos, e por isso estava justificada a sua submissão. Para Sciacca, já se encontra em Lutero, primeiro a exaltar o messianismo da raça germânica (e também o anti-semitismo, convém acrescentar), todos os motivos do futuro totalitarismo alemão:

"Para eles [os pecadores, a ralé] é necessária a esfera do furor divino, a lei da força impiedosa, isto é, a espada do Príncipe, instrumento de Deus. Assim, de um lado, Luther codifica a estatolatria, a obediência cega à autoridade constituída e à lei, a necessidade da guerra; de outro lado, com um pessimismo semelhante ao de Machiavelli, sanciona a condenação da maioria, como aquela que é escrava de instintos e cobiças e, portanto, como aquela que deve ser governada com punho de ferro. Acrescente-se que Luther exige da autoridade civil ordenanças radicais a favor da autarquia econômica alemã, tendo sido o primeiro a exaltar o messianismo da raça e a 
missão providencial do grande império germânico. Há o suficiente para explicar toda a concepção alemã de Estado e de governo, o tradicional antiliberalismo da Alemanha e duas guerras mundiais ${ }^{\prime \prime 8}$

$\mathrm{O}$ renascimento, ao mesmo tempo em que reagia à teologia medieval com a astronomia copernicana, interessava-se pela hierarquia dos anjos, pela magia e pela alquimia. Mas os teóricos do renascimento possuíam uma coisa em comum com os cientistas: a preocupação com as "causas ocultas" que animavam a natureza. É o que vemos, por exemplo, no médico suíço Philippus Aureolus Theophrastus Bombastus von Hohenheim, que conhecemos como Paracelso, por se mostrar superior a Celso, o médico romano. Na obra de Paracelso, presenciamos o ir e vir de conceitos derivados da alquimia, da astrologia e da magia. Para ser mais exato, ele defende todas as artes capazes de revelar as grandes obras de Deus: a astrologia, a adivinhação, a necromancia, a magia, etc. Mas, como médico que lançará as bases da homeopatia, seu apreço é maior pela alquimia.

Contudo, na renascença, o grande esoterismo se fez em torno da astrologia, que veio, de certa forma, substituir a demonologia medieval, trocando a causalidade sobrenatural pela causalidade natural manifestada a partir da influência dos astros. E, nesse mesmo momento, enquanto Nostradamus escrevia suas Centúrias (1555), o trabalho Sobre as revoluções das orbes celestes de Copérnico já completava mais de uma década de sua publicação. Tycho Brahe já era nascido e poucos anos depois nasceria Johann Kepler, cujos trabalhos sérios em astronomia não deixavam de apresentar algum viés místico, já que ele acreditava que, de alguma forma, os astros seriam capazes de influenciar o caráter das pessoas. Sua grande obra de cosmologia $-O$ mistério do Universo - coincide com o nascimento de Descartes (1596-1650), principal precursor do iluminismo e da filosofia moderna.

Com o racionalismo de Descartes, a fé, dizem-nos, é definitivamente substituída pela razão e pela ciência, e o método matemático é alçado ao status de método do conhecimento em geral. A razão podia alcançar tudo e, com o método experimental de Francis Bacon (1561-1626), a natureza poderia ter todos os seus segredos descobertos. Agora, pensamos, todo o misticismo será submetido ao escrutínio da razão e do método científico. Longe disso, muito longe disso, como atestará o próprio movimento romântico no século XVIII.

\footnotetext{
${ }^{88}$ Sciacca, M. F. História da filosofia, vol. II, p. 17.
} 
Enquanto na história oficial da filosofia o século das luzes terá em Descartes seu principal precursor, na história do esoterismo - que corre paralelamente ao desenvolvimento do método experimental - seu principal contraponto será Jacob Böhme. O conhecimento deste homem provinha não da observação meticulosa e de experimentos rigorosos, mas da mais antiga forma de conhecimento: a iluminação mística $^{89}$. Sua primeira iluminação, em 1600, foi enquanto ele contemplava os reflexos da luz em um prato, o que o fez abandonar seu ofício de sapateiro pelos estudos místicos. Sua segunda iluminação foi em 1610. Dois anos depois, Jacob Böhme publica seu primeiro trabalho - Aurora - onde discute os mistérios do mal, o livre-arbítrio, a predestinação, etc. Suas duas iluminações deram origem a uma vasta obra, de mais de 30 livros, sobre Deus, o homem e a natureza ${ }^{90}$.

Mas a França do século XVII viu surgir, ainda antes de Locke e Voltaire, em 1623, a sociedade dos irmãos da Rosa-Cruz. Nas paredes dos prédios parisienses, já abarrotadas de cartazes anunciando todo o tipo de coisas, em uma manhã de 1623 os franceses puderam ler um cartaz que declarava o seguinte:

\footnotetext{
"Nós, representantes da principal sociedade dos irmãos da Rosa-Cruz, estamos ficando visível e invisivelmente na cidade pela graça do Altíssimo, para o qual o coração do Justo se volta. Mostramos e ensinamos sem livros e máscaras como falar a língua de todos os países em que quisermos ficar, para tirar nossos irmãos homens do erro da morte" ${ }^{\prime 1}$.
}

Em um outro cartaz, a sociedade Rosa-Cruz oferecia admissão a todos aqueles que desejassem ingressar na congregação, mas não fornecia nenhum indício do local onde os representantes da sociedade secreta poderiam ser encontrados. Apenas dizia que aqueles que fossem "dignos" seriam reconhecidos e procurados. Mais secreto que isso, impossível, tanto que até hoje não se conhece nenhum "rosacruciano", apesar da enorme influência que essa sociedade secreta exerceu sobre a história do esoterismo.

Sabia-se na França, porém, que essa irmandade já fizera adeptos na Alemanha, Inglaterra e Países Baixos. A Igreja reagiu acusando os "invisíveis" rosa-cruzes de satanistas e instando os parisienses a ficarem vigilantes. Graças ao alvoroço causado na França pelos cartazes, muito se discutiu sobre os rosa-cruzes. Os mais lúcidos,

\footnotetext{
${ }^{89}$ Comunicação interior com Deus e/ou a natureza.

${ }^{90}$ Mistérios do desconhecido: Seitas secretas, p. 53.

${ }^{91}$ Idem, ibidem, p. 46.
} 
descartando a hipótese "oficial" de conspiração demoníaca, acreditavam tratar-se de uma brincadeira elaborada pelos protestantes na intenção de desviar a atenção da igreja, que à época ainda os tinha como alvos privilegiados. Outros pensaram tratar-se de uma manobra publicitária de um ardiloso livreiro na intenção de despertar o interesse dos franceses por um livro recém-editado e intitulado Fama Fraternitatis, que narrava as peripécias de uma estranha figura messiânica (e de seu grupo de seguidores) chamado Christian Rosenkreuz. O título original do panfleto, cujo manuscrito já era conhecido em 1610, era "A reforma universal e geral de todo o amplo mundo; juntamente com o Fama Fraternitatis da louvável fraternidade Rosa-Cruz, escrito para todos os eruditos e soberanos da Europa". Posteriormente a obra foi traduzida para diversas línguas e surgiu impressa pela primeira vez em Kassel, no oeste da Alemanha ${ }^{92}$.

De acordo com o texto, Christian Rosenkreuz, o suposto fundador da irmandade Rosacruz, nascera em 1378 em uma família de nobres alemães empobrecidos e cedo, antes dos cinco anos de idade, já freqüentava um monastério. Quando adulto o jovem viajou para a Terra Santa seguindo depois para Damasco, onde suas habilidades naturais para a medicina atraíram a atenção dos sábios da cidade. De lá, seguiu para a Arábia, onde em Damcar (uma cidade provavelmente mística) os eruditos o receberam tratandoo como a alguém há muito por eles esperado. Em Damcar esses sábios ensinaram-lhe muitos segredos (matemática, física, alquimia) e mostraram-lhe o Livro M. - suposto Livro Mundi, que continha todos os segredos do universo. Depois de três anos de iniciação, ele parte para o Egito e de lá segue para a Espanha na intenção de compartilhar com os homens seus novos conhecimentos. Recebido com escárnio pelos eruditos, ele decide retornar para a Alemanha, concluindo que os homens ainda não estariam preparados para sua reforma moral e intelectual. Mesmo assim ele decide guardar por escrito os conhecimentos que acumulara ao longo dos anos, escritos esses que seriam mantidos em segredo até que a humanidade estivesse pronta para eles. Para tal tarefa, ele recrutou três confrades do monastério de sua infância como assistentes, formando assim uma nova ordem semi-monástica - a dos irmãos da Rosa-Cruz. O conhecimento, sobretudo curativo, era passado assim de geração em geração através dos sucessores de cada um dos irmãos. Conta-se que Christian Rosenkreuz teria morrido em 1484, aos 106 anos, chamado pelo Espírito de Deus, posto que ainda gozava de plena saúde $^{93}$.

\footnotetext{
${ }^{92}$ Idem, ibidem, p. 50.

${ }^{93}$ Idem, ibidem, p. 51.
} 
Agora no século XVIII, já em pleno iluminismo, há apenas alguns anos desde a publicação dos Principia Mathematica de Newton e da descoberta da gravitação universal, encontramos de um lado os iluministas-enciclopedistas e de outro os francomaçons e a ordem dos Illuminati. Friedrich Oetinger (1702-1782) - o "mago do sul" - é uma figura típica desse período. Ele é um iluminista que se comunica com os espíritos, estuda os cabalistas hebreus e os cabalistas cristãos, lê Jacob Böhme e Swedenborg, é pastor luterano e ainda Naturphilosoph (adepto da filosofia da natureza), capaz de explicar o mundo através da atração/repulsão, pela água e pelo fogo ${ }^{94}$.

Enquanto isso, antes mesmo de Oetinger publicar o seu Theologia ex idea vitae deducta (1765), na academia de São Petersburgo, Leonhard Euler (1707-1783) já era considerado, aos 26 anos, um dos maiores matemáticos da época. Responsável pela atual linguagem e notação dos símbolos que hoje utilizamos na matemática $(\sqrt{(-1)}=\mathrm{i}$, $\pi, \Sigma, \mathrm{f}(\mathrm{x}))$, Euler criou a análise infinita baseada em funções algébricas, trigonométricas, logarítmicas e exponenciais. E nesse mesmo período, Abraham de Moivre (1667-1754) desenvolvia sua célebre "Doutrina das probabilidades" (1718) e publicava seu "Miscelânea analítica", no qual dá à trigonometria um tratamento analítico. E não podemos nos esquecer, é claro, de Laplace (1749-1827).

Mas foi também nessa época que as "ciências ocultas" se desenvolveram em torno de Cagliostro, de Saint-Germain e dos "iluminados de Avignon" que tentavam, com sucesso, comunicarem-se com os anjos. Cagliostro era mais um desses sábios que adquiriram sua sabedoria através de iniciações no oriente. Já o conde de Saint-Germain, este provavelmente foi o maior de todos os impostores: dizia poder fazer tudo o que quisesse com a natureza e afirmava ter mais de 300 anos. Na França iluminada pela luz da razão haviam muitas pessoas dispostas a dar-lhe crédito, como foi o caso de Louis XIV e de Mme. Pompadour. Nesse momento, na "medicina oculta", Mesmer dedicavase ao magnetismo animal.

No século XIX, aprendemos que a ciência se consolida definitivamente, com os desenvolvimentos nas matemáticas, na física, na biologia e na geologia. O mecanicismo impera de forma absoluta como a forma mais adequada para se entender a natureza. Proliferam na França e na Inglaterra as instituições científicas. A química finalmente parece ter enterrado seu passado alquímico com os estudos de Kekulé (1829-1896), descobridor das leis de ligação dos átomos de carbono, com a classificação periódica

\footnotetext{
${ }^{94}$ Riffard, P. O esoterismo, p. 649.
} 
dos elementos e as previsões de Mendeleyev (1834-1907) e com os estudos de Pasteur (1822-1895). A radioatividade também estava sendo estudada, ou melhor, estava sendo descoberta por Antoine Becquerel (1852-1909) e estudada por Marie Curie (18671934).

Mas é também nessa época de consolidação da teoria atômica e das leis da termodinâmica - tempo em que Napoleão redesenhava o mapa da Europa e a Revolução Industrial se desenvolvia a pleno vapor - que Helena Petrovna Blavatsky (1875) cria a sociedade antroposófica e o ocultismo ganha novo impulso com Éliphas Lévi (18101875) e com o médico neo-ocultista Papus (1865-1916). Mas não é somente a antroposofia que domina o cenário europeu do século XIX. Este século testemunha um profundo interesse na evocação dos espíritos, como atestam o caso das irmãs Fox, por volta de 1848 nos EUA e com a fundação, por Allan Kardec, do espiritismo na França (1857).

O caso de Blavatsky é dos mais interessantes por articular muitas das teorias científicas disponíveis no século XIX (sobretudo na biologia evolucionista) com suas revelações místicas. Na verdade, tais descobertas serviram para justificar as informações mitológicas recolhidas em suas viagens ao oriente, confirmando assim os mitos, enquanto que, por outro lado, ela utilizava as incipientes especulações geológicas para fundamentar sua cosmologia. Como sabemos hoje, a geologia começou a tornar-se uma ciência autônoma ao longo do século XVII atingindo sua maturidade no século XIX, sobretudo após a revolução industrial, quando o trabalho nas minas de carvão levou a descoberta de diversos fósseis de criaturas gigantescas e que não mais existiam sobre a Terra. Tais fósseis, entretanto, não eram de todo desconhecidos na antiguidade, tanto que foram objeto de relatos já no mundo grego.

No ocidente cristão, os restos de tais criaturas eram muitas vezes expostos nas portas das igrejas como comprovação do relato bíblico acerca do dilúvio e, sobretudo, da existência dos gigantes. A Teoria da Evolução das Espécies de Darwin veio em auxílio aos geólogos que estavam sendo acusados de fomentar o ceticismo e o ateísmo ao fazerem recuar cada vez mais a idade da Terra - na tentativa de explicarem as formações geológicas - para muito antes dos 6.000 anos supostos pela igreja, número esse apoiado pela maioria dos cientistas da época. Mas a teoria de Darwin, para se sustentar, precisava mesmo que esse número fosse estimado na casa dos milhões de anos, talvez bilhões, única forma de se garantir a plausibilidade de uma evolução lenta e 
gradual, e por muito tempo o recuo dos estudos científicos para "apenas" 100 milhões de anos na datação da idade da Terra foi a principal objeção ao darwinismo.

E é exatamente na trilha desses desenvolvimentos científicos que se coloca o problema da modernidade. Por mais que notemos hoje a tendência a explicar todas as mazelas do mundo a partir do surgimento da modernidade ou da crise da modernidade, alguns movimentos não podem prescindir do estudo das alterações materiais e culturais acarretadas pela modernidade. Não nos interessa aqui discutir de forma exaustiva o que possibilitou sua emergência, mas situar o renascimento do ocultismo na Alemanha mais como uma reação de oposição (como foi o caso do romantismo também) do que como um produto natural desse processo. $\mathrm{O}$ romantismo já foi bastante analisado, mas o ocultismo da época sempre figurou aí como um mero capítulo, de pouquíssimas páginas, quando na verdade ambos representam a reação frente a um inimigo comum. Por mais que o ocultismo do século XIX reflita elementos do romantismo, não podemos reduzir aquele a este. Comecemos, então, com a modernidade, para entendermos a que se opunham os românticos e os ocultistas.

Marshall Berman divide a história da modernidade em três fases. A primeira vai do início do século XVI até o final do século XVIII, quando as pessoas estão apenas começando a vivenciar o mundo moderno. A segunda fase ele fixa no início das grandes ondas revolucionárias orientadas pela burguesia, sobretudo a Revolução Francesa, momento este que dura até o final do século XIX. Neste período começa a surgir um verdadeiro público moderno que tem consciência de estar vivendo uma era revolucionária de "explosivas convulsões em todos os níveis de vida pessoal, social e política”, mas o homem desse período, afirma Berman, ainda se lembra do que é viver num mundo de transição que não chegou a ser moderno por inteiro, e "é dessa profunda dicotomia, desta sensação de viver em dois mundos simultaneamente, que emerge e se desdobra a idéia de modernismo e modernização" 95 . O terceiro e último período tem início no século XX, com um processo de modernização que abarca o mundo todo, mas à medida que se expande perde nitidez e sua capacidade de dar sentido à vida das pessoas. Para Berman,

"Existe um espaço de experiência vital - experiência de tempo e espaço, de si mesmo e dos outros, das possibilidades e perigos da vida - que é compartilhada por homens e mulheres em todo o mundo, hoje. Designarei esse conjunto de experiências

\footnotetext{
${ }^{95}$ Berman, M. Tudo que é sólido desmancha no ar, p. 16.
} 
como 'modernidade'. Ser moderno é encontrar-se em um ambiente que promete aventura, poder, alegria, crescimento, autotransformação e transformação das coisas em redor - mas ao mesmo tempo ameaça destruir tudo o que temos, tudo o que sabemos, tudo o que somos. A experiência ambiental da modernidade anula todas as fronteiras geográficas e raciais, de classe e nacionalidade, de religião e ideologia; nesse sentido, pode-se dizer que a modernidade une a espécie humana. Porém, é uma unidade paradoxal, uma unidade de desunidade, de luta e contradição, de ambigüidade e angústia. Ser moderno é fazer parte de um universo no qual, como disse Marx, tudo o que é sólido desmancha no ar" ${ }^{, 96}$.

Ser moderno é, então, viver em um imenso turbilhão de idéias, valores, objetos, religiões, ideologias políticas, etc. E a sensação dessas pessoas, afirma Berman, é de que elas "estão aptas a sentir-se como as primeiras, e talvez as últimas, a passar por isso" E aqui verificamos logo uma questão já apontada por Walter Benjamin, de que jamais houve uma época que não se sentisse moderna ou frente a uma crise iminente. Para ele, isso seria um estado crônico da humanidade. Até que ponto, então, poderíamos estar nós, modernos, tão certos de que essa nossa época é critica ou apocalíptica? Absolutamente nenhum. Os judeus certamente sentiram-se assim quando estiveram no exílio, o mundo grego na época da sua dissolução, o homem da baixa idade média, aquele do renascimento, o homem da revolução francesa e da revolução russa. E, mais recentemente, o homem que viveu os tempos de horror das duas grandes guerras mundiais.

Mas se esse sentimento de estar sempre vivenciando um momento de crise iminente é crônico em nossa história, não é menos verdade que nos séculos XIX e XX, por vezes em uma única geração ou uma única década, a velocidade das transformações, a velocidade do turbilhão que arrastou o homem moderno à destruição de barreiras morais e religiosas jamais, em época alguma, fôra tão rápida. A estruturação psicológica do homem moderno não consegue se ajustar à velocidade das transformações; na maioria das vezes, até a perde de vista, e o resultado disso é um estado permanente de confusão, de aturdimento... O homem da baixa idade média, se vivia num estado de confusão similar, certamente não via tantas mudanças, tantas transformações, ao longo de uma única vida. Ferrovias modernas, jornais diários, telégrafo, telefones, máquinas a vapor, fábricas automatizadas, microprocessadores, computadores, carros com motor a

\footnotetext{
${ }^{96}$ Idem, ibidem, p. 15.

${ }^{97}$ Idem, ibidem, p. 15.
} 
explosão, televisão, rádios, etc., tudo isso em pouco mais de um século. A velocidade das mudanças faz com que o homem moderno vivencie mais crises em vinte anos que o homem medieval em uma vida inteira. Além do fato de que este vivia bem menos que nós.

É impossível desvincular, portanto, a modernidade da ascensão da burguesia como classe dominante e do surgimento do operariado. Marx, em seu Manifesto do Partido Comunista, afirma que a história de todas as sociedades sempre foi a história das lutas de classes, e pinta a partir dessa oposição a imagem da nova classe emergente. A burguesia foi a primeira a provar a capacidade da atividade humana em criar maravilhas ainda maiores que as pirâmides do Egito e as catedrais góticas, arrastando a "civilização", devido ao aperfeiçoamento dos instrumentos de produção, mesmo as nações mais bárbaras, obrigando-as, sob pena de morte, a adotarem o modo burguês de produção. Mas a sociedade burguesa moderna, "que conjurou gigantescos meios de produção e troca, assemelha-se ao feiticeiro que já não pode controlar as potências internas que pôs em movimento com suas palavras mágicas" ${ }^{\text {"98 }}$.

Em parte a afirmação de Marx diz respeito ao surgimento, junto com a burguesia e criada por ela, da arma que lhe daria a morte: os operários modernos. E em parte se refere à enorme quantidade de energia criativa liberada que foge ao controle da própria classe que lhe deu origem, e partindo daí ele resume a modernidade:

"Essa subversão contínua da produção, esse abalo constante de todo o sistema social, essa agitação permanente e essa falta de segurança distinguem a época burguesa de todas as precedentes. Dissolvem-se todas as relações sociais antigas e cristalizadas com seu cortejo de concepções e de idéias secularmente veneradas; as relações que as substituem tornam-se antiquadas antes de se ossificar. Tudo o que era sólido e estável se esfuma, tudo o que era sagrado é profanado, e os homens são obrigados finalmente a encarar com serenidade suas condições de existência e suas relações recíprocas"

A sociedade moderna, por tudo o que já vimos, é, assim, politeísta, como afirma Weber. Mas não se trata mais de um politeísmo de deuses, mas de valores. Desencantamento e secularização operaram a perda da unidade que era fornecida aos indivíduos através da figura de Deus ou de quaisquer outros valores de caráter universalista, "tudo o que era sólido se esfuma". Se a modernização pode ser concebida

\footnotetext{
${ }^{98}$ Marx, K. Manifesto do partido comunista, p. 24.

${ }^{99}$ Idem, ibidem, p. 20.
} 
como um processo histórico universal de racionalização, a modernidade seria o momento em que se supõe terminado este processo ou, com certo rigor histórico-social, um momento muito representativo de um estágio avançado desse processo. E o capitalismo que Marx critica é um momento desse processo de racionalização que propõe Weber. Na Ética protestante e o espírito do capitalismo, Weber esclarece que o empreendedor, o aventureiro capitalista e o próprio capitalismo sempre existiram. Não é o "impulso para o ganho" ou a "ânsia do lucro" que caracteriza o capitalismo do ocidente moderno - esse impulso sempre existiu. A diferença é que o ocidente "veio a conhecer, na era moderna, um tipo completamente diverso e nunca antes encontrado no capitalismo: a organização capitalística racional assentada no trabalho livre (formalmente pelo menos)" ${ }^{\prime 100}$.

Organização industrial racional, separação da empresa da economia doméstica, criação de uma contabilidade racional, em uma palavra, racionalização é o que caracteriza o capitalismo ocidental moderno. A racionalização, porém, e seu avatar mais famoso, a ciência, não são capazes de levar o homem a Deus, ou de dar qualquer sentido à vida do homem. O destino do homem "é o de viver numa época indiferente a Deus e aos profetas”. Mas em uma época que é politeísta, como dissemos, mas não mais de deuses, "Que deus devemos servir dente os muitos que se combatem? Devemos, talvez, servir um outro deus, mas qual?"101, é o que se pergunta o homem moderno em um mundo de pluralidade de valores. E "a quem não é capaz de suportar virilmente esse destino de uma época", arremata, "só cabe dar o conselho seguinte: volta em silêncio, sem dar a teu gesto a publicidade habitual dos renegados, com simplicidade e recolhimento, aos braços abertos e cheios de misericórdia das velhas igrejas. Elas não tornarão penoso o retorno" $" 102$.

É essa época, que se define como moderna, em que vemos o desenvolvimento nunca antes imaginado de todas as potencialidades construtivas (e destrutivas) do capitalismo moderno que possibilitou o surgimento, ancorado exatamente neste desenvolvimento, de uma também moderna sociedade de consumo. Mas não se trata apenas de uma mudança na produção material. A própria ciência havia progredido muito, servindo como meio para o amadurecimento da modernidade. No final do século XVIII, a matemática já operava com funções algébricas e logarítmicas e no início do

\footnotetext{
${ }^{100}$ Weber, M. A ética protestante e o espírito do capitalismo, p. 7.

${ }^{101}$ Weber, M. A ciência como vocação, p. 48.

${ }^{102}$ Idem, ibidem, p. 51.
} 
século XIX, com o desenvolvimento da física, da química, da biologia e da geologia, a ciência, mais que nunca, parecia apta a fornecer explicação para todos os fenômenos materiais.

Mas a modernidade também acaretou um incremento do irracionalismo em meados do século XVIII. Essa tendência pode ser explica em parte como uma reação ao reformismo político dos príncipes absolutista ilustrado da Alemanha que interferiram em muitos privilégios legais estabelecido, o que incluía os assuntos da igreja. O irracionalismo surgiu como uma arma ideológica conservadora contra as tendêcias inovadoras da época ${ }^{103}$. Mas velhos motivos vieram se somar aos novos, como o surto de pietismo na Alemanha, movimento místico nascido no seio do luteranismo e que, como vimos, recusava os padrões objetivos da religião pela vivência religiosa íntima e fervorosa.

O evolucionismo de Mme. Blavatsky é um bizarro exemplo disso. Inspirada pelos debates modernos, que ocorriam nos "limites estreitos da ciência", Blavatsky decide recuar a origem do homem a milhões de anos incorporando a tudo isso uma evolução também do espírito. Entretanto, o comportamento de Blavatsky em aceitar em parte a teoria da evolução não deve ser creditado ao seu "espírito científico" em oposição aos preconceitos religiosos vigentes. Ela aceitou da evolução apenas aquilo que estava de acordo com suas concepções místicas, ou seja, aceitou a idéia de uma sucessão lenta e gradativa das espécies, mas em um arco descendente, desde suas formas mais espirituais até suas formas materiais, mas negou a evolução do homem tal como descrita por Darwin. Para ela, a evolução era apenas parte de um processo que implicava também a degradação, sendo assim, de acordo com suas iluminações espirituais, o homem não teria se originado dos símios, mas estes é que seriam o resultado de um processo de degradação, fruto do cruzamento de pais humanos com mães semi-humanas. O resultado disso seriam tribos primitivas semi-animalescas, como era o caso de algumas tribos de selvagens australianos. Estava lançada a semente para o racismo moderno que veremos no século XX.

Quando Ísis desvelada (1877) e logo em seguida A doutrina secreta (1888) foram publicados, a teoria da evolução de Darwin já era uma explicação bastante influente acerca da origem dos animais e dos homens. Mas era uma teoria - como todas as teorias da ciência - materialista. E é contra isso que se opõem todos os ocultismos e

\footnotetext{
${ }^{103}$ Goodrick-Clarke, Las oscuras raices del nazismo, p. 85.
} 
também o romantismo. Max Horkheimer resume bem o problema contra o qual se estava lutando. $\mathrm{O}$ argumento é o de que o sujeito da ciência positivista não possui emoções nem história, é um mero sujeito do conhecimento, tão abstrato quanto a natureza que ele pretende estudar. Mas se o método torna abstrata a natureza, isso não quer dizer que ela seja abstrata, ou mesmo que o seja o sujeito. O pensamento cientificista, que se contenta em organizar e catalogar os dados da natureza, esgota-se na descrição, e "o mesmo aparato conceptual (begnifflicher Apparat) empregado na determinação da natureza inerte serve também para classificar a natureza viva, e podendo ser utilizado a qualquer momento por toda pessoa que tenha aprendido o seu manejo" ${ }^{104}$. A exigência fundamental da ciência, aponta Horkheimer, é a de que todas as partes do sistema teórico estejam conectadas sem contradição, mas mesmo apesar das críticas, não há dúvida do sucesso dessa forma de pensamento quanto ao manejo da natureza física e quanto à importância desse modo de funcionamento da ciência para os progressos técnicos da idade burguesa, como também não há dúvidas quanto ao desenvolvimento material que esta sociedade conseguiu alcançar graças a esse método.

Ora, é exatamente contra isso que se batem todos os ocultistas e todos os românticos. Esse é o caso de Guénon, que condena abertamente o mundo moderno e sua ciência profana, contrapondo-lhes as culturas tradicionais e sua relação com o sagrado:

\begin{abstract}
“toda ciência 'profana' que se desenvolveu no decurso dos últimos séculos vê apenas o estado do mundo sensível, encerrou-se aí exclusivamente, e os seus métodos só são aplicáveis a esse domínio; ora, esses métodos são proclamados 'científicos' com exclusão de qualquer outro, o que é o mesmo que negar toda ciência que não se relacione com as coisas materiais (...) Quando se vê uma ciência exclusivamente material apresentar-se como uma única ciência possível, quando os homens se habituam a admitir como verdade indiscutível que não pode haver conhecimento válido fora desta, quando toda a educação que lhes é dada tende a inculcar-lhes a superstição desta ciência, que vem a ser o cientificismo, como é que esses homens poderiam não ser praticamente materialistas, ou seja, não ter todas as suas preocupações viradas para o lado da matéria?"
\end{abstract}

Julius Evola expressa uma opinião semelhante ao discutir a existência, no passado, de uma ciência não só diferente, mas superior à nossa. Então, pouco a pouco, uma outra ciência passou a tomar forma, uma ciência "puramente humana e física, da

\footnotetext{
${ }^{104}$ Horkheimer, M. Teoria crítica e teoria tradicional, p. 31.

${ }^{105}$ Guénon, R. A crise do mundo moderno, p. 77.
} 
qual os modernos estão tão orgulhosos" ${ }^{\text {"106 }}$. Porém, em Evola, o elemento elitista e o ressentimento acerca da democratização do saber é muito maior. Ele critica, sobretudo, a democratização do conhecimento acarretado pela ciência tanto quanto seu materialismo:

"É ela [a ciência moderna] que degradou e democratizou a noção mesma de saber, estabelecendo o critério uniformista da verdade e da certeza, fundada sobre o mundo sem alma das cifras sobre a superstição do método positivo (...) é ela quem tornou impossível a compreensão das disciplinas tradicionais graças à miragem de evidências acessíveis a todos, tem afirmado a superioridade da cultura laica”, ${ }^{, 107}$.

Por mais que Evola também se refira ao Ragnarök escandinavo, tanto ele como Guénon preferem identificar o mundo moderno com a noção hinduísta da Kali yuga, ou seja, a era das trevas, quando todas as tradições são esquecidas. Isso nos mostra que de Blavatsky até Julius Evola, passando por Guénon e pelos românticos, o argumento é sempre o mesmo. Mas os trabalhos de Mme. Blavatsky, pela precedência no tempo e pela envergadura, são representativos da preocupação que movia a crítica antimoderna no século XIX. Lembremos, por exemplo, do subtítulo de A doutrina secreta: "síntese da ciência, da religião e da filosofia". Para ela, a ciência oculta deve ser consultada sempre que a ciência exata decide aventurar-se para além dos limites dos fenômenos observados. Para Blavatsky, a ciência moderna seria incapaz de desvendar os mistérios do universo, estando apta apenas a colecionar, classificar e generalizar os fenômenos. Já o ocultista, calcado em princípios metafísicos, seria capaz de sondar os mais recônditos segredos da natureza. Cabe ao ocultista preencher o vácuo criado pelo adormecimento das capacidades da atual Quinta Raça-Raiz. E, não podemos deixar de notar, Blavatsky recebeu tais concepções do além.

O ocultismo é, em parte, uma reação contra a vulgarização do conhecimento empreendida pela aristocracia decadente e pela burguesia emergente, que se manifesta através de uma crítica da modernidade em favor de um retorno à tradição. A disciplina do arcano - a proibição de divulgar, a exigência do segredo e do mistério - própria do esoterismo, possui suas próprias justificativas, mas não podemos aceitá-las ingenuamente. Pierre Riffard, o historiador do esoterismo, cita algumas: o iniciado não pode dizer ao não-iniciado aquilo que ele não pode entender e nesse caso o iniciado é

\footnotetext{
${ }^{106}$ Evola, J. Revuelta contra el mundo moderno (parte II, cap. 13)

${ }^{107}$ Idem, ibidem.
} 
para o profano aquilo que o sábio é para o analfabeto; se o profano tentasse entender o ensinamento acabaria por deformá-lo, convertendo-o em mal e, por conta disso, o conhecimento oculto seria perigoso para os não-iniciados ${ }^{108}$. Apesar de suas volumosas publicações, Blavatsky deixa claro, em diversos momentos, que só está tornando público aquilo que lhe é permitido; o restante não seriamos capazes de compreender ou seria perigoso se soubéssemos.

De certa forma, o rancor contra a ciência moderna não é apenas porque esta se mostra arrogante quanto às suas possibilidades de tudo explicar, por sua obsessão com o materialismo, em suma, não é o "cientificismo" o alvo do ocultismo: seu alvo é a violação da aristocrática "disciplina do arcano". Não porque seja perigoso e antiético divulgar o conhecimento aos profanos, porque sua preocupação, por mais que muitos acreditem nisso, não é devida a excesso de zelo, mas à possibilidade da perda de sua posição privilegiada como portadores de um conhecimento que lhes garante o prestígio conseguido exatamente por sua posição social como sábios. A crítica de Julius Evola à "democratização da noção mesma de saber" é inequívoca quanto a isso, mas a força desse argumento prescinde da confissão de Evola.

A exemplo daquilo que tinha acontecido no século XVIII com a Enciclopédia obra que reuniu, com seus 60.000 verbetes e 160 colaboradores, todo o estado geral da cultura da época, disponibilizando esse conhecimento a leitores que pretendiam estar bem informados com o menor esforço possível - o século XIX também contou com seus veículos de divulgação, como o Journal des Savants, a Edinburg Review, a Westminster Review e a Popular Science Monthly, dentre outras coisas. Esse material de divulgação da ciência tinha dois objetivos: "o primeiro era adaptá-la aos leigos, interessados na ciência mas não especialistas. O segundo era informar os cientistas ativos em uma disciplina sobre aquilo que estava acontecendo em outras"109. Aqui, porém, diferente do século XVIII, quando o ideal renascentista do homem universal ainda era possível e a filosofia natural ainda fazia parte da cultura de pessoas instruídas, no final do século XIX, com o afastamento dos cientistas das humanidades, a ciência converteu-se em uma segunda cultura, com prejuízos tanto para as humanidades quanto para as ciências naturais. E assim a "ciência revestiu seus praticantes de uma aura de

\footnotetext{
${ }^{108}$ Riffard, P. O esoterismo, p. 255.

${ }^{109}$ Mora, A. M. S. A divulgação da ciência como literatura, p. 23.
} 
superioridade, ao mesmo tempo em que ela transformou-se em paradigma das outras formas de vida intelectual" ${ }^{\prime 10}$.

E foram numerosas e importantes as descobertas científicas dos séculos XVIII e XIX. O desenvolvimento da química havia mostrado a impossibilidade da transmutação dos metais vulgares em ouro, e na biologia Darwin reescrevia a história do homem desacreditando as genealogias calcadas nos relatos da Bíblia. Quanto à física, desde Newton, ainda no século XVII, grande parte dos "mistérios da natureza" vinham sendo elucidados, sobretudo graças às leis da gravitação universal.

O discurso dos ocultistas precisava se adaptar aos novos tempos. A ciência movida pelo método cartesiano tornava-se, apesar do esforço de divulgação, cada vez mais obscura para os não-iniciados. Fato bastante perturbador para os místicos desse período, que percebiam sua "iniciação" nos mistérios ocultos da natureza como algo absolutamente inútil nesses novos tempos em que eles também se percebiam como "não-iniciados", tanto quanto o homem comum. E não era possível, graças a crescente credibilidade da ciência, ao seu poder explicativo, enfim, a seu sucesso prático, criticála ou combatê-la, sobretudo em seu próprio terreno. Além do mais, para a ciência, tudo pode e deve ser submetido ao escrutínio da razão, o que viola o próprio pressuposto do esoterismo expressado na "disciplina do arcano". Enquanto a ciência tenta tornar claros seus pressupostos e tornar públicas suas descobertas, o ocultismo esforça-se para manter o segredo, disfarçando seus conhecimentos com uma série infindável de ocultações. Seu "método", calcado em "analogias" e "correspondências" (de certa forma também presentes na ciência moderna), muito freqüentemente conduzem a erros de raciocínio e de argumentação que a ciência se esforça para evitar. O próprio Freud argumenta que “(...) ser-nos-á difícil evitar a suspeita de que o interesse pelo ocultismo é, de fato, um interesse religioso e que um dos motivos secretos do movimento ocultista é vir em auxílio da religião, ameaçada como ela está pelo avanço do pensamento científico" "111

Mas é inevitável manter com a ciência algum tipo de diálogo, nem que seja para reformular as próprias especulações metafísicas do ocultismo, herdadas dos séculos anteriores e agora totalmente desacreditadas graças ao progresso da ciência. Por isso, apesar das críticas (e ao contrário das suposições correntes), o ocultista respeita a ciência e apenas em raras ocasiões tenta negá-la totalmente. Por isso Blavatsky aponta que

\footnotetext{
${ }^{110}$ Idem, ibidem, p. 21.

${ }^{111}$ Freud, Sigmund. Novas conferências introdutórias sobre psicanálise.
} 
"enquanto suas [da ciência] deduções estiverem baseadas em premissas exatas, e suas generalizações assentarem sobre uma base puramente indutiva, todos os teósofos e ocultistas acolherão, com o respeito e a admiração devida, sua contribuição no domínio da lei cosmológica. Não pode haver conflito possível entre os ensinamentos da Ciência Oculta e os da chamada Ciência Exata, sempre que as conclusões dessa última estejam alicerçadas em fatos irrecusáveis" ${ }^{112}$.

O problema se dá quando a ciência tenta extrapolar os seus limites, os limites dos fenômenos observados, com o objetivo de alcançar a essência do ser, coisa que ela faz reduzindo as forças vivas do cosmos à matéria cega. É isso que, segundo Blavatsky, o ocultista rejeita. De fato, em parte, também é isso, mas não é só essa a angústia do ocultista. Tomemos como exemplo o caso da alquimia. Os alquimistas eram homens interessados em questões muito práticas, nada muito diferente dos cientistas de hoje, apesar do misticismo: a transformação de metais vulgares em ouro. Mas nesse caminho, que levou a avanços na química, esses homens, trabalhando em seus laboratórios com balanças para pesar as substâncias químicas, pilão, almofariz e alambiques, aplicaram seus conhecimentos também à medicina. Paracelso, por exemplo, estimulava a utilização de "exames de laboratório" - como a análise química da urina a partir da destilação - no diagnóstico de doenças. E havia especulações bem mais ousadas. Ele acreditava que seria possível criar um "homem artificial" (parece que essa era uma idéia bastante difundida no século XVI), chamado de homúnculo, simplesmente colocando sêmen em um frasco hermeticamente fechado que deveria ser posteriormente enterrado em esterco de cavalo por quarenta dias e depois magnetizá-lo. Em seguida, o já formado, porém invisível ser, deveria ser mantido à temperatura do ventre de uma vaca e alimentado com sangue humano por quarenta semanas, quando já estaria parecido com uma criança pequena.

Bem, com a ciência moderna, provou-se a impossibilidade da transmutação dos metais, pelo menos fora de grandes e modernos laboratórios e ao custo de milhões de dólares. Os alquimistas modernos não tinham como competir com essas inovações, o que motivava suas críticas à ciência, ao progresso e à modernidade. Depois disso, a alquimia e os alquimistas modernos racionalizaram as frustradas tentativas de transmutação afirmando que o real objetivo da alquimia nunca fôra esse, mas a busca do

${ }^{112}$ Blavatsky, H. P. A doutrina secreta, vol. II, p. 187. 
auto-conhecimento ou da salvação espiritual, o que está muito longe da verdade. Para alguns alquimistas que não comungavam dessas interpretações "simbólicas", não eram necessários caros laboratórios de pesquisa para levar adiante a transmutação: graças ao conhecimento oculto (conservado em enigmáticos tratados alquímicos), era muito simples realizar a transmutação, para isso bastando apenas uma cozinha comum e um fogão.

$\mathrm{O}$ argumento da simplicidade de complicados procedimentos técnicos ganha a coloração de um delírio místico porque é uma tentativa de reação à ciência moderna, que baniu os diletantes da sua história, convertendo os "iniciados" do ocultismo em "não-iniciados" da ciência, enquanto tomava para si o monopólio da explicação do mundo. Um exemplo desse processo foi a tentativa de Guido von List, em 1903, de tentar impressionar a Academia imperial de Ciências de Viena com um trabalho acerca da protolinguagem dos arianos baseado em uma metodologia ocultista que analisava o simbolismo das runas e os emblemas de antigas inscrições desse povo. Rejeitado pela ciência, foi preciso fundar uma sociedade (Sociedade List) interessada em publicar esse tipo de investigação claramente pseudo-científica. O caso, que chegou até o parlamento, onde se exigia que o ministro da educação e cultura desse explicações sobre o silêncio acerca do trabalho de List, não intimidou a Academia de Ciências. 


\title{
VII. UM DESAFIO PARA O SÉCULO XXI: O RESSURGIMENTO DAS IDÉIAS RACIAIS E O NEONAZISMO ESOTÉRICO
}

\begin{abstract}
"Hegel observa, em algum lugar, que todos os fatos e personagens de grande importância na história mundial acontecem duas vezes, por assim dizer. Esqueceu-se de acrescentar: da primeira, como uma grande tragédia; da segunda, como uma farsa lamentável".
\end{abstract}

(Karl Marx)

Nos EUA o surgimento do neonazismo remonta à década de 1950, tempo em que os movimentos religiosos de caráter místico que dominariam o cenário religioso dos anos 1960 estavam sendo gerados. No cenário político estava aberta a temporada de caça aos representantes da "ameaça vermelha", fruto do "pânico vermelho" originado pelo triunfo do comunismo na China e no leste europeu. A perseguição encabeçada por Joseph McCarthy tinha alguma semelhança com a tentativa obsessiva de Hitler em destruir a União Soviética, semelhança que não passou despercebida a alguns grupos descontentes com o liberalismo e os judeus. Na década seguinte, o movimento negro, exigindo direitos civis, agravou ainda mais uma situação que se tornaria explosiva na década de 1980, quando a imigração de latinos em busca de emprego se tornou mais intensa. Os grupos neonazistas prontamente se apresentariam em defesa da sobrevivência da raça branca.

O "führer" norte-americano da década de 1960 chamava-se George Lincoln Rockwell. Filho de um pai de origem inglesa e escocesa e mãe franco-alemã (ambos atores de teatro), Rockwell nasceu em 1918 em Bloominggton, Illinois. Como estudante de filosofia e sociologia na Universidade Brown em 1938 ele rapidamente identificou (a partir de suas tendências igualitárias) "comunismo" com "liberalismo", mas mesmo assim, e graças à perspectiva de guerra seu sentimento inicial era anti-alemão. Após ter lutado em duas guerras (a Segunda Guerra Mundial e a Guerra da Coréia), seu medo paranóico do comunismo só fez aumentar. Os delírios anti-comunistas de McCarthy conduziram Rockwell a se interessar progressivamente pelas teorias conspiracionistas como aquelas do jornal anti-semita Common Sense, que denunciava um complô judeucomunista atuando nos bastidores da história e conduzindo os rumos do século XX na 
intenção de conseguir o poder mundial ${ }^{1}$. Esse argumento, já conhecido desde o Protocolo dos Sábios de Sião, parecia plausível e, como todo paranóico, Rockwell interpretou o silêncio dos meios de comunicação acerca da conspiração como uma confirmação da própria conspiração. A conclusão seguinte era igualmente compreensível: por que então os EUA haviam lutado contra a Alemanha na guerra e não como sua aliada? Após a leitura do Mein Kampf ele se converteu definitvamente ao nacional-socialismo e converteu-se, anos depois, no principal líder do partido nazista americano.

Depois de algumas visões e encontros místicos com Hitler, ele reúne, através de seus discursos inflamados, um pequeno grupo de "soldados" para formar sua tropa de assalto. Dentre os planos de Rockwell estava repatriar os negros para a África e criar um projeto de eugenia para purificar a raça ariana. Tudo isso acontecia exatamente no momento em que Martin Luther King mobilizava os negros em sua luta por direitos civis, movimento que Rockwell interpretou como instigado por judeus. Associando-se a Colin Jordan, um líder neonazista britânico, ele cria em 1962 a União Mundial dos Nacional-Socialistas (World Union of National-Socialists - WUNS), cuja direção inicialmente deveria ficar a cargo de Jordan, mas que acabou sendo dirigido pelo próprio Rockwell. A partir de 1966, o WUNS já contava com uma nova publicação, o National Socialist World, cujo objetivo era divulgar seu programa acerca do poder ariano global. Um dos números da revista divulgava o trabalho de Savitri Devi (19051982), uma fervorosa devota de Hitler e especialista em hinduismo e arianismo:

"Na década de 1950, ela se juntou ao submundo nacionalista alemão, tornandose amiga íntima de líderes dos efêmeros partidos neonazistas e visitando notórios emigrados nazistas no Egio e na Espanha. Com sua exótica formação hindu, ela forneceu aos defensores do nazismo uma declaração descaradamente pagã e anticristã da doutrina de Hitler"2.

Essa divulgação da propaganda nazista na Alemanha ocupada a levou à prisão em 1949, pena cumprida na Inglaterra. Essa mulher curiosa, espécie de madame Blavatsky do pós-guerra, nascera em Lyons em 1905. Ainda na juventude rejeitara o cristianismo (e também o judaísmo) em nome dos "deuses derrotados" do paganismo, e em sua viagem à Índia, em 1932, ela busca encontrar na tradicional cultura ariano-

\footnotetext{
${ }^{1}$ Goodrick-Clarke, N. Sol negro: cultos arianos, nazismo esotérico e políticas de identidade, p. 19-20.

${ }^{2}$ Idem, ibidem, p. 117.
} 
védica (como fizera Blavatsky) as crenças e os deuses pagãos obscurecidos pelo triunfo do cristianismo.

Calcada nas crenças hinduístas, ela acreditava no ciclo de eras (ou yugas) presentes no Vishnu Purana, antiga lenda do hinduismo que apontava para a existência de quatro yugas que se sucediam de forma cíclica descrevendo o declínio do mundo a partir de uma era dourada até a decadência total rumo a uma era de trevas - a Kali yuga. Para Savitri Devi o mundo havia ingressado na era das trevas por volta de 3000 a.C., com o predomínio do judaísmo, do cristianismo e dos movimentos libertários do século XVIII. Sua "teoria da história" expressava a crença em grandes heróis divididos em "Homens do Tempo", "Homens acima do Tempo" e "Homens contra o Tempo". Os primeiros representavam a decadência do Kali yuga, ou seja, eram homens violentos, bárbaros representantes da decadência como o líder mongol Genghis Khan (1157-1227). Os Homens acima do Tempo eram seres espiritualizados representantes da perfeição do Satya yuga, a era dourada, caso do faraó egípcio Akhenaton (1370-1340 a.C.). Já os Homens contra o Tempo eram heróis salvadores que agiam com crueldade mas na intenção de salvar o mundo da Kali yuga, dando início a uma nova era dourada. Esses conceitos estavam associados à noção hindu de que periodicamente uma divindade (geralmente Vishnu) descia encarnado à Terra em forma humana, animal ou supra humana, como foi o caso de Krishna. Savitri Devi acreditava que Hitler, o maior de todos os Homens contra o Tempo seria um desses avatares, escolhido para salvar a raça ariana e trazer de volta à Terra uma nova era de luz, perfeição, justiça e retidão:

"Sua demanda [de Hitler] por unidade nacional alemã em um novo e poderoso Reich em desafio ao humilhante Tratado de Versalhes claramente o identificava para ela como o campeão do antigo princípio tribal contra o capitalismo degenerado e a ordem cosmopolita dos Aliados. Sua adoção de idéias racistas, seu anti-semitismo e sua implantação das Leis de Nuremberg proibindo casamentos mistos e relações sexuais entre arianos e judeus convenceram-na de que ele procurava levar a uma revivificação do sistema de castas ariano em escala mundial. O uso brutal da violência militar contra seus inimigos em um mundo decaído resistente por parte de Adolf Hitler, e seu plano irredutível de exterminar os judeus, os ancestrais adversários e contra-imagem dos heróicos arianos, caracterizavam-no como o Homem conta o Tempo essencial”,3.

\footnotetext{
${ }^{3}$ Idem, ibidem, p. 127.
} 
Pois bem, foi exatamente essa mulher quem exerceu profunda influência sobre os "filósofos" do neonazismo Colin Jordan e Rockwell, como se pode notar pelas publicações do Nationl Socialist World, o novo periódico do WUNS. Nele enfatizava-se a importância dos EUA na guerra racial vindoura que oporia brancos (mais ou menos) arianos contra negros e judeus. Essa ênfase devia-se a William Luther Pierce, um físico que havia sido indicado por Rockwell à vaga de editor da revista. Anos depois, esse mesmo Pierce publicaria um romance que pode ser considerado o maior clássico da literatura neonazista. O diário de Turner (The Turner diaries), publicado em 1978 e traduzido para outros idiomas, inclusive o português, até hoje pode ser facilmente encontrado na rede mundial de computadores. $\mathrm{O}$ romance narra exatamente esse confronto, em um futuro não tão distante, entre um grupo armado revolucionário branco contra o "Sistema", que apóia negros e judeus, também chamado de ZOG (Governo de Ocupação Sionista) em alusão ao governo norte-americano fantoche, dirigido por judeus $^{4}$. Esse Mein Kampf moderno e apocalíptico inspiraria o movimento neonazista em todo o mundo, porém, como o romance localizava a rebelião no final do século XX, agora sabemos que ela não pode se realizar.

Em 1967, Rockwell rebatizou o partido com o nome de National Socialist White People's Party (NSWPP), ou seja, Partido Nacional-Socialista do Povo Branco, assumido por Matt Koehl, um filho de imigrantes húngaros de ascendência alemã, logo após a morte de Rockwell. Não é fácil traçar a história intrincada desses pequenos grupos neonazistas organizados em partidos políticos de extrema-direita que desaparecem constantemente, mas que ressurgem sempre com ânimo renovado alguns anos depois, mas sabemos que nos EUA grupos de extrema direita reverenciam a memória de Rockwell e ainda hoje sofrem a influência de Peirce que, até onde pude investigar, permanecia em plena atividade no ano 2000. Esses grupos racistas, a Igreja de Jesus Cristo Cristão, o Nações Arianas, a Igreja de Cristo, dentre outros, todos originários do movimento Identidade Cristã e muito vagamente cristãos, apesar das denominações. A Identidade Cristã, em sua origem na Inglaterra, afirmava serem os anglo-saxões como a raça eleita, identificando-os com as tribos perdidas de Israel.

$\mathrm{Na}$ Inglaterra, a propósito, o movimento neonazista estava vinculado a Colin Jordan, o homem que pela primeira vez, em 1962, decidiu romper o constrangimento causado pelo neonazismo na Europa que fazia com que os grupos de extrema-direita se

\footnotetext{
${ }^{4}$ PIERCE, Willian W. O diário de Turner.
} 
distanciassem de qualquer relação com Hitler e o nazismo. Nascido em 1923 em Birmingham, Inglaterra, Jordan, quando estudante de História em Cambridge, já travava contato com grupos nacionalistas como o Partido do Povo Britânico, ao qual se afiliou. O pano de fundo do movimento neonazista na Inglaterra foi o afluxo de imigrantes das colônias inglesas para a metrópole no pós-guerra. Novos agrupamentos políticos surgiram tendo como projeto exatamente o controle da imigração, como foi o caso da Liga de Defesa Branca, fundada por Colin Jordan. A chegada de imigrantes negros serviu para fortalecer as idéias racistas e nazistas de Jordan, que a partir de 1959 defendia a causa da unidade racial nórdica através do periódico The Nationalist. Ao longo dos anos 1970 e 1980 esses pequenos grupos neonazistas nunca conseguiram reunir mais que algumas centenas de membros efetivos, mas suas atividades, muitas vezes terroristas (contra judeus e outras minorias), criaram todo um clima de ódio racial em momentos de tensão sempre forneciam os clichês para a ação de extremistas e vândalos como os skinheads e os hooligans.

O mais importante desses grupos, porém, surgiu no início dos anos 1990 como uma tentativa de reviver os planos de Jordan de um submundo nazista militante. Descendente do British National Socialist Movement (BNSM), o Combate 18 (C18) era um grupo de guerrilha que mobilizava marginais, jovens militaristas e skinheads para ataques físicos, atentados a bomba e incêndios criminosos contra inimigos raciais. $\mathrm{O}$ número 18 que aparece no nome da organização derivava do nome Adolf Hitler, cuja letra "A" corresponde à primeira letra do alfabeto e a letra final " $H$ " corresponde à oitava letra. Formado a partir do BNSM, de grupos de skinheads e gangues de futebol racistas (West Ham, Charlton, Leeds, Millwall e Chelsea headhunters),

\footnotetext{
“o C18 é uma conspiração criminosa armada, que reúne informações e mobiliza suas células para realizar atos de violência contra seus alvos escolhidos, que já incluíram políticos trabalhistas, membros do Parlamento, ativistas ambientalistas e membros de organizações judias. Ao distribuir listas de alvos com os endereços e telefones pessoais de seus inimigos, ele busca incutir o medo em seus oponentes, mostrando que está sempre pronto para realizar ataques-surpresa",
}

Um de seus lemas era HUMILHAR - DESMORALIZAR - DESTRUIR e seus ataques, inspirados pela "guerra racial" tinham como objetivo intimidar as minorias

\footnotetext{
${ }^{5}$ Idem, ibidem, p. 62.
} 
étnicas e os membros de partidos comunistas. Suas críticas eram contra um governo que insistia em respeitar negros, homossexuais e oferecer benefícios sociais a grupos minoritários com o dinheiro da maioria branca. $\mathrm{O}$ repúdio era à constituição de uma sociedade multirracial.

$\mathrm{Na}$ Áustria, onde a experiência nazista foi sinal de catástrofe, não havia essa adoração explícita a Hitler, típica da Inglaterra e dos EUA; porém, nesse país cuja história sempre esteve tão ligada à Alemanha algo ainda mais bizarro aconteceu. A partir da década de 1950 grupos leais ao nazismo desenvolveram uma mitologia que confirma muitas das ligações que tecemos neste trabalho entre o nacional-socialismo e as vertentes esotéricas. Longe da política, essa mitologia desenvolveu especulações as mais ousadas acerca das antigas raças nórdicas, continentes perdidos, paganismo germânico, interessando-se pela antiga Ahnenerbe de Himmler e - acreditem - armas milagrosas, discos voadores e bases secretas escondidas nos pólos.

A atração do nacional-socialismo pelo o ocultismo era refreada, de certa forma, pelas possibilidades - objetivas - de reconstruir uma ordem antiga pela força, já que isso atenuava o conteúdo dos delírios tendo em conta que o ocultismo refletia a impotência do sujeito diante de um mundo sentido como estranho, o qual se é incapaz de transformar através da ação. No caso do nazismo, foi possível tornar o delírio real, o que reduz a necessidade da imaginação alçar vôos ainda mais altos. Porém, no tocante aos grupos surgidos após o desastre alemão, a ligação entre o desejo frustrado e a imaginação mística era mais evidente, mais bizarra, ou seja, tanto maior quanto menor era a possibilidade de realizar a grandeza alemã.

O foco das discussões ocultistas no círculo de Wilhelm Landig (1909-1997) era um centro secreto no Ártico conhecido como ilha azul. Esses homens acreditavam mesmo ser possível entrar em contato com esse centro espiritual através de exercícios de meditação. Tudo cabia nesse amontoado de crenças esotéricas inspiradas em todas as influências que já analisamos neste trabalho: tradição dos cátaros, Otto Rahn, o mito do Graal, rosacrucianismo, alquimia, enfim. Desatar o nó dessas crenças exigiria um outro trabalho como este. Dentre essas crenças, a única grande novidade era a importância atribuía aos OVNIS (isso mesmo, Objetos Voadores Não-Identificados).

Um nome importante nessa nova geração de ocultistas do pós-guerra era Rudolf Mund, que inspirado pelos trabalhos de Edmund Ki $\beta$ sobre a teoria do gelo mundial de Horbiger e as lendas sobre o Graal de Otto Rahn, Mund entrou na Ordem dos Novos Templários (ONT) em 1958, descobrindo aí o misticismo de Karl Maria Wiligut. Mas 
não havia apenas esoterismo nesse círculo neo-nazista. Landig era desde a década de 1950 o representante, na Áustria, da organização fascista internacional denominada Movimento Social Europeu (ESB). De acordo com o historiador Goodrick-Clarke,

\begin{abstract}
"foram os romances do próprio Landig que asseguraram a revivificação dos temas ocultista-nacionalistas em uma nova geração de neonazistas na década de 1990. As idéias e interesses discutidos pelo grupo de Landig na década de 1950 encontraram expressão permanente na trilogia de romances de Thule escrita por Landig. O primeiro deles, Götzen gegen Thule (1971), foi iniciado na década de 1950 e incorporava o pensamento de Julius Evola e de Herman Wiuth. Teorias de origens polares dos arianos e Atlântida misturavam-se com novos e poderosos mitos nacionalistas do 'último batalhão', bases secretas alemãs de OVNIs, de alquimia, de mitos do Graal e de heresias cátaras, e uma conexão nazist tibetana que envolvia os mestres himalaias e um reino subterrâneo na Mongólia"
\end{abstract}

Algo absolutamente curioso no movimento neonazista é que diferente daquilo que se imagina ele não precisa, necessariamente, estar vinculado ao culto ariano. Isso explica, por exemplo, como é possível encontrar neonazistas em lugares os mais inusitados, como Japão, Coréia ou mesmo Brasil. E os neonazistas coreanos não são "loiros de olhos azuis", são de aparência asiática mesmo, ou seja, são coreanos legítimos. A confusão gerou até mesmo uma tentativa de alterar a denominação dos grupos que demonstravam clara inspiração anti-semita com a convicção clássica de que os arianos (loiros) seriam a raça eleita de "nazistas" apesar do distanciamento histórico de um movimento já "extinto".

É por conta mesmo desse distanciamento que discordamos desse ponto de vista: grupos racistas de inspiração nazista, calcados na superioridade racial devem ser denominados "neonazistas". Porém, percebemos que esse termo dificilmente poderia ser aplicado a agrupamentos racistas na Ásia ou no mundo em desenvolvimento, tendo em conta o sentido consagrado do termo "nazismo". Nessas regiões, o que vemos é uma luta por identidade cultural e nacional, motivada sobretudo pelo crescente problema da imigração, que pode muitas vezes surgir no interior de um mesmo país, como é o caso dos "carecas" da cidade de São Paulo e seu ódio contra os nordestinos. Isso explicaria, por exemplo, a bizarrice de encontrarmos "neonazistas" em paises asiáticos.

\footnotetext{
${ }^{6}$ Idem, ibidem, p. 178-179.
} 
Esses grupos de jovens, tal como os conhecemos hoje, não surgiram inicialmente na Alemanha como pudemos notar, mas na Inglaterra e logo em seguida nos EUA, que por sua vez já contava com um movimento racista próprio e muito peculiar, representado pela Ku Klux Klan. Paralelamente ao desenvolvimento desses grupos, desenvolveram-se não apenas novas idéias ocultistas à margem da ciência, mas tentativas no meio universitário de propostas visando contestar a existência do Holocausto.

No início da década de 1990, a própria organização Combate 18 foi muito favorecida pela necessidade de um grupo de cães de guarda capazes de realizar a segurança de eventos de extrema-direita, como as palestras de David Irving. Esse historiador britânico chegou a afirmar que em Auschwitz os judeus morriam não gaseados, mas apenas de tifo. Unido a partidários do revisionismo histórico desde a década de 1970, Irving perdeu sua reputação no meio acadêmico mas ganhou notoriedade nos meios extremistas internacionais, realizando conferências para um público mais interessado no ódio racial do que na história da Segunda Guerra. Os argumentos de Irving pretendem construir uma imagem positiva de Hitler afirmando, apesar dos relatos em Nuremberg e das confissões de Eichmann em Jerusalém, que as câmaras de gás seriam uma ficção, e que Hitler não teria ordenado nenhuma solução final. Parte da análise está calcada na ausência de documentação que realmente apontasse que Hitler teria dado a ordem para a solução final; o resto ele resolveu desacreditando fontes históricas existentes, como ao afirmar que o Diário de Anne Frank era uma fraude criada por seu pai ${ }^{7}$. Em 2006, David Irving, então com 67 anos, foi condenado por um tribunal austríaco a cumprir três anos de prisão por negar o holocausto, atitude considerada crime na Áustria. Porém, ele continua em liberdade.

Para quem pensa que isso só acontece na Europa e que estudar o neonazismo no Brasil seria algo no mínimo estéril, vale apontar que no Rio Grande do Sul, em Porto Alegre, existe uma editora especializada em divulgar material negacionista. De acordo com o editorial da "Revisão Editora e Livraria Ltda", disponível na rede mundial de computadores,

“O Revisionismo Histórico vem lutando ao longo dos últimos 50 anos no sentido do resgate da Verdade Histórica. Iniciando em fins dos anos 40 com breves e despercebidas

\footnotetext{
${ }^{7}$ De fato, o pai de Anne Frank suprimiu, ou seja, "censurou" determinados fragmentos do diário da filha, mas não inventou as deportações, as peseguições, enfim, o holocausto.
} 
- apesar de contundentes e irretorquíveis - contestações às inverdades e calúnias arquitetadas pelo sionismo judaico internacional - que iniciava àquela época o assalto final dentro do seu milenar plano de domínio mundial - a idéia revisionista vem obtendo reconhecimento e impulso sempre crescentes".

Fundada em 1987 por Siegfried Ellwanger (pseudônimo S. E. Castan), a Revisão Editora funciona como uma imensa biblioteca onde grupos racistas podem buscar informações sobre o revisionismo histórico e adquirir livros sobre o tema. Vários textos escritos por S. E. Castan podem ser facilmente acessados pelo computador e, em um deles, Castan chama Auschwitz de "Waterloo dos insanos" afirmando que no máximo 65.960 pessoas tenham sido cremadas ali. Seu argumento, baseado em exames de técnicos poloneses e norte-americanos, aponta para a impossibilidade técnica da existência de câmaras de gás utilizadas para o extermínio de judeus. Aquilo que ele chama de "A mentira do século" (a cifra de mais de 1.000.000 de mortos em Auschwitz) faria parte de um plano para apresentar a nação vencida como uma nação criminosa, "preparando o caminho para o linchamento de Nuremberg, onde, ao enforcarem as mais altas autoridades alemãs, calaram para sempre os únicos que, com absoluto e total conhecimento de causa, poderiam desmascarar qualquer intento de iniciar a farsa do holocausto" ${ }^{\sharp}$. Sem comentários.

É possível entender a reação do Ministério Público às atividades da Revisão Editora, contudo, convém ficarmos atentos aos excessos. Há algum tempo, a Editora Centauro, que até onde sei não tem como objetivo divulgar livros de conteúdo racista, reeditou o Mein Kampf de Hitler e Os Protocolos dos Sábios de Sião (de autoria anônima, como sabemos). Para os pesquisadores do assunto isso foi uma ótima notícia, afinal, não era nada fácil adquirir esses livros, sobretudo "Os Protocolos". Porém, a partir de uma ação movida pela Federação Israelita do Estado de São Paulo, o Ministério Público de São Paulo recolheu os exemplares dos "Protocolos" do depósito da Editora Centauro sob o argumento de que eles constituíam divulgação de material anti-semita. Esperamos que esse precedente não traga funestas conseqüências para o trabalho dos pesquisadores no futuro.

Pois bem, nos anos de 1990, o neonazismo anglo-americano enveredou por novos caminhos com as bandas de rock black-metal e seus fanáticos ouvintes adeptos da cosmologia nórdica, magia, ocultismo e satanismo nazista. O principal precursor dessa

\footnotetext{
${ }^{8}$ Revisão Editora. Porto Alegre, Rio Grande do Sul.
} 
nova tendência foi o inglês Aleister Crowley, conhecido como "o homem mais perverso do mundo", ou simplesmente "a besta". Filho de um austero cristão cervejeiro, membro da seita Irmãos de Plymouth, que Crowley detestava, esse inglês misterioso foi membro de diversas seitas ocultistas e passou sua vida dedicando-se a pequenos prazeres mórbidos, dignos de qualquer psicopata que faça justiça a esse diagnóstico. Conta-se que "para pôr a prova o adágio de que o gato tem nove vidas, ele administrou arsênico a um, cloroformizou-o, pendurou-o sobre um bico de gás, esfaqueou-o, cortou-lhe a garganta, esmagou-lhe o crânio, queimou-o, afogou-o e atirou-o pela janela"`. Para Aleister Crowley, o mal era uma busca religiosa cujo lema era o hedonismo expresso na forma do "faz o que quiserdes será toda a lei".

Ainda muito jovem, Crowley ingressou em 1888 na Ordem Hermética da Aurora Dourada, um pequeno grupo de ocultistas interessados em magia aplicada e que era a principal concorrente da Sociedade Teosófica de Mme Blavatsky. Sua intenção de impor seu domínio sobre a ordem culminou com sua expulsão 12 anos depois, levandoo a ingressar na Ordo Templi Orientis (OTO), ou Ordem dos Templários do Oriente, organização maçônica criada na Alemanha em 1902 que entendia o sexo ritualizado como uma experiência sobrenatural. Anos depois fundou sua própria seita, a Argentium Astrum (AA) - Estrela de Prata - que contava com o sacrifício de animais (e conta-se que de bebês também, o que é pouco provável) onde se bebia seu sangue. Um de seus discípulos chegou a morrer em um desses rituais regados a sangue, álcool, drogas e sexo. O tema do sexo e drogas aliado à rebeldia religiosa será o grande atrativo dos grupos de black-metal, isso é certo, já as especulações de que Hitler estaria seguindo as profecias do Livro da Lei (que proclamava uma nova era - o novo Aeon de Hórus - de força e muito sangue) são bem mais fantasiosas. Aleister Crowley morreu em 1947, mas lançou as bases do neonazismo satanista, cujo representante contemporâneo é Anton Szandor La Vey (1930-1997).

Conhecido como o "Papa Negro", La Vey fundou em São Francisco, em 1966, a Igreja de Satã. Esse ex-músico e domador de leões que partilhava das crenças de Crowley acerca da magia sexual e do hedonismo, escreveu nessa época sua "Bíblia Satânica", texto bastante divulgado sob a forma digital e que conta, inclusive, com uma tradução para o português. O texto é leitura corrente no submundo neonazista por sua inspiração no darwinismo social. Em seu prólogo temos alusões ao anel dos nibelungos,

\footnotetext{
${ }^{9}$ Mistérios do desconhecido, Seitas Secretas, p. 113.
} 
a Loki e a Valhalla, temas típicos do paganismo nórdico, e dentre as "nove declarações satânicas", La Vey identifica Satan como sabedoria pura e bondade apenas para aqueles que a merecem ${ }^{10}$. Uma espécie de anticristo de Nietzsche para um público vulgar e pósmoderno. O elemento comum a esses grupos satanistas nazistas é o ódio ao cristianismo, ao judaísmo e à idéia de sociedades multinacionais percebendo a luta pela sobrevivência entre os diferentes grupos raciais e culturais como necessário à evolução do ser humano.

Já há alguns anos o governo alemão vem intensificando programas de combate à xenofobia e ao neonazismo, e grupos como a "Aliança pela democracia e tolerância contra extremismo e violência" vem exigindo uma ação mais enérgica do governo, porém, como notou em 2001 o próprio presidente do parlamento alemão Wolfgang Thierse, ele está longe de ser eliminado, como atestam os mais de 1000 sites na rede mundial de computadores pregando o racismo e a violência. $\mathrm{O}$ argumento de Thierse continua sendo aquele da migração, mas o fenômeno não pode ser controlado apenas com uma política de migração global como supõe Thierse. Nesse mesmo ano, pouco antes da constatação do presidente do Parlamento, a Ministra da Família e Juventude, Christine Bergmann apresentou em Berlim um programa para combater o extremismo (apoiado nos 65 milhões de marcos disponibilizados pelo governo) cujo alvo é a formação política da juventude alemã e que tem como estratégia fomentar a tolerância e a convivência pacífica com os estrangeiros, sobretudo no leste alemão.

Dois anos depois, em 2003, a polícia alemã conseguiu desmantelar um grupo de militantes neonazistas do Combate 18 que comercializava CDs de músicas com conteúdo racista. Mas apesar da repressão policial, são freqüentes as marchas neonazistas na Alemanha, que chegam a reunir, como na passeata de comemoração da morte de Rudolf Hess, cerca de 3000 neonazistas, na cidade de Wunsiedel, em 2004. Mesmo ano em que, convém notar, morria nos EUA, aos 86 anos, Richard Butler, fundador do grupo neonazista Nações Arianas, aliado da Ku Klux Klan e dos skinheads. No mês seguinte, o ministério do interior proibiu uma nova tentativa de desfile neonazista promovido pelo NPD no dia da $31^{\mathrm{a}}$ maratona internacional em Berlim, mas não conseguiu conter, no começo de 2005, uma passeata ainda maior que a de Wunsiedel, quando 5000 neonazistas marcharam em Dresden, no leste do país, ao som de Richard Wagner. E, pior que isso, em 2005, um ano após Wunsiedel, grupos

\footnotetext{
${ }^{10}$ LAVEY, Anton Szandor. A bíblia Satânica.
} 
neonazistas foram proibidos de comemorar novamente o aniversário de Hess naquela cidade, mas o NPD conseguiu junto ao tribunal constitucional alemão uma autorização para realizar a passeata em Nuremberg, onde Hess foi julgado.

Contudo, esta política repressiva um dia já foi bem mais tolerante, e aquilo que hoje parece um surto de irracionalidade, um anacronismo absurdo de tempos idos, só causa tanta comoção e só é combatido com energia porque perdeu o apoio do Estado. Mas nem sempre foi assim, e quando falo de "apoio" não estou me referindo aos anos dourados do nazismo na Alemanha, porque os movimentos de extrema-direita mantiveram sua utilidade mesmo após o movimento de desnazificação. Se a ameaça comunista, elemento que agrupou a burguesia em torno de regimes políticos fortes, continuou a existir no pós-guerra, nada mais natural que grupos extremistas que tinham como pauta o combate ao socialismo fossem tratados com tolerância.

Com o fim da Segunda Guerra e a emergência da Guerra Fria, aponta Paulo Fagundes Vizentini, paises onde a esquerda era forte (Grécia, Itália e França) mantiveram-se no campo ocidental, enquanto que aqueles onde a esquerda era fraca (Polônia, Hungria e Romênia) foram captados pelo bloco soviético. Ora, nesses países, sobretudo naqueles do primeiro grupo, tornou-se necessário dotá-los de partidos e grandes formações de centro e de direita com o objetivo de estabelecer um equilíbrio de forças capaz de evitar a vitória da esquerda. Esses grupos irão, evidentemente, modificar o seu discurso em solidariedade às democracias liberais, ou seja, passarão a defender o anti-comunismo denunciando ativamente a ditadura nos paises do leste europeu, enquanto ignoravam seu passado fascista. $\mathrm{O}$ ocidente passou assim a utilizar os "serviços" de ex-nazistas, como Klaus Barbie, empregado pelos norte-americanos como projetista de foguetes. Outro exemplo, dos mais indigestos na Europa ocidental, é aquele da organização paramilitar Gládio, descoberta a partir da investigação da loja maçônica P2. O grupo, responsável pelo atentado de Bolonha em 1980 e pelo assassinato de Aldo Moro da Democracia Cristã Italiana (a culpa recaiu sobre as Brigadas Vermelhas, grupo de extrema-esquerda) era utilizado para atacar sindicatos, políticos e organizações sociais de esquerda, sendo utilizado como "uma virtual segunda linha de defesa da OTAN, no caso de uma guerra e de uma invasão soviética" ${ }^{\prime 1}$.

Como se vê, o ventre que deu origem ao nazismo continua fecundo.

\footnotetext{
${ }^{11}$ Vizentini, P. F. O ressurgimento da extrema direita e do neonazismo: a dimensão histórica e internacional, p. 3-5.
} 


\section{REFERÊNCIAS}

ADORNO, Theodor. Mínima Moralia. São Paulo, Ática, 1993.

ADORNO, Theodor; HORKHEIMER, Max. Dialética do Esclarecimento. Rio de Janeiro, Jorge Zahar, 1985.

ALEXANDRIAN, História da filosofia oculta. Lisboa, Edições 70, s.d.

ANGEBERT, Jean-Michel. Hitler e as religiões da suástica. Lisboa, Bertrand, 1977.

ARENDT, Hannah. Eichmann em Jerusalém: um relato sobre a banalidade do mal. São Paulo, Companhia das Letras, 1999.

.Origens do Totalitarismo: anti-semitismo, imperialismo, totalitarismo. São Paulo, Companhia das Letras, 2004.

BERMAN, Marshall. Tudo que é sólido desmancha no ar. São Paulo, Companhia das Letras, 1986.

BION, W. R. Dinâmica do grupo: uma revisão. In: KLEIN, Melanie; HEIMANN, Paula; MONEY-KIRLE, R. E. (org). Temas de psicanálise aplicada. Rio de Janeiro, Zahar editores, 1969.

BLAVATSKY, Helena Petrovna. A doutrina secreta: síntese da ciência, religião e filosofia. 6 v. São Paulo, Pensamento, s.d.

BRÜSEKE, Franz Josef. Romantismo, mística e escatologia política. In: Lua Nova $n^{0}$ 62. São Paulo, CEDEC, 2004.

CARLYLE, Thomas. Os heróis. Lisboa, Guimarães, 1953.

CONTE, Edouard; ESSNER, Cornelia. A demanda da raça: uma antropologia do nazismo. Lisboa, Instituto Piaget, 1998.

CORES, Pablo Jiménez. A estratégia de Hitler: as raízes ocultas do nacionalsocialismo. São Paulo, Madras, 2006.

DAMERGIAN, Sueli. Para além da barbárie civilizatória: o amor e a ética humanista. Tese de livre-docência. São Paulo, Instituto de Psicologia da Universidade de São Paulo (IPUSP), 2007.

DIWAN, Pietra. Raça pura: uma história da eugenia no Brasil e no mundo. São Paulo, Contexto, 2007. 
D'ONOFRIO, Salvatore. Literatura ocidental: autores e obras fundamentais. São Paulo, Ática, 2004.

DUMESNIL, René. Vidas de Wagner e Massenet. São Paulo, Atena, 1957.

ELIADE, Mircea. Mito e realidade. São Paulo, Perspectiva, 1972.

ELIAS, Norbert. Os Alemães. Rio de Janeiro, Jorge Zahar, 1997.

ENRIQUEZ, Eugène. Da Orda ao Estado: Psicanálise do Vinculo Social. Rio de Janeiro, Jorge Zahar Editor, 1990.

EVOLA, Julius. Revuelta contra el mundo moderno. In: http://juliusevola.blogia .com/temas/revuelta-contra-el-mundo-moderno.php (último acesso em 2 de janeiro de 2008)

FEST, Joachim. Hitler. Rio de Janeiro, Nova Fronteira, 1976.

FORNARI, F. Por uma psicanálise das instituições. In: Kaës, René (org). A instituição e as instituições. São Paulo, Casa do Psicólogo, 1991.

FREUD, Sigmund. Suplemento metapsicológico à teoria dos sonhos (v. XIV). In: Edição eletrônica das obras psicológicas completas de Sigmund Freud. Rio de Janeiro, Imago, s. d.

Psicologia e análise do Ego (v. XVIII). In: Edição eletrônica das obras psicológicas completas de Sigmund Freud. Rio de Janeiro, Imago, s. d.

A perda da realidade na neurose e na psicose (v. XIX). In: Edição eletrônica das obras psicológicas completas de Sigmund Freud. Rio de Janeiro, Imago, s. d.

O futuro de uma ilusão (v. XXI). In: Edição eletrônica das obras psicológicas completas de Sigmund Freud. Rio de Janeiro, Imago, s. d.

Novas conferências introdutórias sobre psicanálise (v. XXII). In: Edição eletrônica das obras psicológicas completas de Sigmund Freud. Rio de Janeiro, Imago, s. d.

GALLI, G. Hitler e o nazismo mágico: as componentes esotéricas do III Reich. Lisboa, Edições 70, s. d.

GOLDENSOHN, Leon. As entrevistas de Nuremberg. São Paulo, Companhia das Letras, 2005.

GOODRICK-CLARKE, Nicholas. Sol Negro: cultos arianos, nazismo esotérico e políticas de identidade. São Paulo, Madras, 2004.

Las oscuras raices del nazismo. Buenos Aires, Sudamericana, 2005. 
GRUNBERGER, R. A história das SS. Rio de Janeiro, Record, s.d.

GUÉNON, René. A crise do mundo moderno. Lisboa, Vega, s. d.

GUINSBURG, Jacob (org.). O romantismo. São Paulo, Perspectiva, 1978.

HEGEL, Wilhelm. História filosófica. In: GARDINER, Patrick (org.). Teorias da História. Lisboa, Calouste Gulbenkian, 1974.

HERDER, Johann G. Idéias para a filosofia da história da humanidade. In:GARDINER, Patrick (org.). Teorias da História. Lisboa, Calouste Gulbenkian, 1974.

HITLER, Adolf. Minha Luta. São Paulo, Centauro, 2001.

HOLLINRAKE, Roger. Nietzsche / Wagner e a filosofia do pessimismo. Rio de Janeiro, Zahar, 1994.

HOOK, Sidney. O herói na história. Rio de Janeiro, Zahar, 1962.

HORKHEIMER, Max. Teoria crítica e teoria tradicional. In: ARANTES, Paulo Eduardo (org.). Horkheimer/Adorno: vida e obra. São Paulo, Nova Cultural, 1991.

KANT, Immanuel. Idéia de uma história universal de um ponto de vista cosmopolita. In: GARDINER, Patrick (org.). Teorias da História. Lisboa, Calouste Gulbenkian, 1974.

KITCHEN, Martin. Um mundo em chamas: uma breve história da Segunda Guerra Mundial na Europa e na Ásia, 1939-1945. Rio de Janeiro, Jorge Zahar, 1993.

KONDER, Leandro. Introdução ao fascismo. Rio de Janeiro, Edições Graal, 1979.

LAVEY, Anton Szandor. A Bíblia Satânica. In: http://www.uouwww.com/2008/10/abiblia-satanica-szandor-lavey.html (último acesso em 5 de janeiro de 2009)

LUDWIG, Emil. Os alemães: dupla história duma nação. Rio de Janeiro, José Olympio, 1941.

LUKÁCS, G. El asalto a la razón. Barcelona, Grijalbo, 1978.

MACEDO, I. Nietzsche, Bayreuth e a época trágica dos gregos. In: Kriterion, $\mathrm{n}^{\mathrm{o}} 112$, Belo Horizonte, dez/2005

MANNHEIM, Hermann. Criminologia comparada. Lisboa, Fundação Calouste Gulbenkiaw, 1984.

MARX, Karl. Concepção materialista da história. In: GARDINER, Patrick (org.). Teorias da História. Lisboa, Calouste Gulbenkian, 1974. 
MARX, Karl; ENGELS, Friedrich. Manifesto do partido comunista. Belo Horizonte, Liga operária e camponesa, 1998.

MASON, S. F., História da ciência. Rio de Janeiro, Globo, 1964.

MELEIRO, Maria Lucília F. A mitologia dos povos germânicos. Lisboa, Presença, 1994.

MELLO, Leonel Itaussu Almeida. Quem tem medo da geopolítica? São Paulo, Edusp, 1999.

MESQUITA, Fábio L. de A. Schopenhauer e o oriente. Dissertação de mestrado. São Paulo, FFLCH-USP, 2007.

MILLINGTON, Barry. Wagner, um compêndio. Rio de Janeiro, Jorge Zahar, 1995.

MISTÉRIOS DO DESCONHECIDO. Seitas secretas. Rio de Janeiro, Abril coleções, s.d.

MONIZ, Luiz Cláudio. Mito e música em Wagner e Nietzsche. São Paulo, Madras, 2007.

MORA, Ana María Sánchez. A divulgação da ciência como literatura. Rio de Janeiro, Editora da UFRJ, 2003.

NEUMANN, Franz. Behemoth: pensamiento y acción en el nacional-socialismo. México D. F, Fondo de cultura económica, 2005.

NIETZSCHE, Friedrich. O caso Wagner. São Paulo, Companhia das Letras, 1999. Nietzsche contra Wagner. São Paulo, Companhia das Letras, 1999. . A gaia ciência. São Paulo, Companhia das Letras, 2001. Para além do bem e do mal. São Paulo, Martin Claret, 2002.

PAUWELS, Louis; BERGIER, Jacques. O despertar dos mágicos. Rio de Janeiro, Difel, 1977.

PIERCE, Willian W. O diário de Turner. In: http://natvan.com/portuguese/turnerdiaries/ (último acesso em 16 de junho de 2008)

PICHOT, André. O eugenismo: geneticistas apanhados pela filantropia. Lisboa, Instituto Piaget, s. d.

PLEKHANOV, Georgi. O papel do indivíduo na história. In: GARDINER, Patrick (org.). Teorias da História. Lisboa, Calouste Gulbenkian, 1974.

POLIAKOV, Leon. O mito ariano. São Paulo, Perspectiva/EDUSP, 1974. 
De Voltaire a Wagner. São Paulo, Perspectiva, 1985.

OS PROTOCOLOS DOS SÁBIOS DE SIÃO. http://www.downgratis.com/2008/02/osprotocolos-dos-sabios-de-siao/ (último acesso em 10 de dezembro de 2008)

REICH, Wilhelm. Psicologia de Massas do Fascismo. São Paulo, Marins Fontes, 2001.

REVISÃO EDITORA. In: http://members.libreopinion.com/us/revision5/edrevision.htm (último acesso em 25 de maio de 2007)

RIBEIRO Jr., João. Que é nazismo?. São Paulo, Brasiliense, 1991.

RIFFARD, Pierre. O esoterismo.São Paulo, Mandarim, 1996.

SEGAL, Hanna. O silêncio é o verdadeiro crime. In: Costa, Gley P. (org.). Guerra e Morte. Rio de Janeiro, Imago, 1988.

SCIACCA, Michele Federico. História da Filosofia. São Paulo, Mestre Jou, 1966.

SORLIN, Pierre. O anti-semitismo alemão. São Paulo, Perspectiva, 1974.

TÁCITO, C. C. Germânia. In: http://www.ricardocosta.com/textos/germania.htm (acesso em 22 de setembro de 2008).

VIZENTINI, Paulo Gilberto Fagundes. O ressurgimento da extrema-direita e do neonazismo: a dimensão histórica e internacional. In: VIZENTINI, Paulo Gilberto Fagundes; MILMAN, Luís (org). Neonazismo, negacionismo e extremismo político. Porto Alegre, Editora da UFRGS, 2000.

WAGNER, R. A arte e a revolução. Lisboa, Antígona, 1990.

Tetralogia do anel. In: http://www.supercable.es/ ealmagro/kareol/obra .htm (acesso em 10 de setembro de 2007).

WEBER, M. Ciência e política: duas vocações. São Paulo, Cultrix, 1985.

Economia e sociedade. Brasília, UnB, 1991.

Pioneira, 1999.

A ética protestante e o espírito do capitalismo. São Paulo, Editora Ensaios de sociologia. Rio de Janeiro, LTC, 2002. 